\title{
CARACTERIZAÇÃO ENZIMÁTICA DAS CELULASES XF-810, XF-818 E XF-2708 DE Xylella fastidiosa E PURIFICAÇÃO DA PROTEÍNA XF-818, EXPRESSAS EM Escherichia coli
}

\author{
NELSON ARNO WULFF
}

Tese apresentada à Escola Superior de Agricultura "Luiz de Queiroz", Universidade de São Paulo, para obtenção do título de Doutor em Agronomia, Área de Concentração: Microbiologia Agrícola.

P I R A C I C A B A

Estado de São Paulo - Brasil

Setembro - 2002 


\section{CARACTERIZAÇÃO ENZIMÁTICA DAS CELULASES XF-810, XF-818 E XF-2708 DE Xylella fastidiosa E PURIFICAÇÃO DA PROTEÍNA XF-818, EXPRESSAS EM Escherichia coli}

\section{NELSON ARNO WULFF}

Licenciado em Ciências Biológicas

Orientador: Prof. Dr. SÉRGIO FLORENTINO PASCHOLATI

Tese apresentada à Escola Superior de Agricultura "Luiz de Queiroz", Universidade de São Paulo, para obtenção do título de Doutor em Agronomia, Área de Concentração: Microbiologia Agrícola.

P I R A C I C A B A

Estado de São Paulo - Brasil

Setembro - 2002 
Dados Internacionais de Catalogação na Publicação (CIP)
DIVISÃO DE BIBLIOTECA E DOCUMENTAÇÃO - ESALQ/USP

Wulff, Nelson Amo

Cara c terização enzimátic a das c elulases XF-810, XF-818 e XF-2708 de

Xylella fa stidiosa e purific ação da proteína XF-818, expressasem Escherichia coli / Nelson Amo Wulff. - - Piracicaba, 2002.

196 p. : il.

Tese (doutorado) - Escola Superior de Agricultura Luiz de Queiroz, 2002.

Bibliografia.

1. Bac téria fitopatogênica 2. Clonagem 3. Clorose-va riega da-dos-citros 4. Enzima s celulolític as 5. Esc heric hia coli 6. Expressã o gênic a I. Título

CDD 589.9

"Permitida a cópia total ou parcial deste documento, desde que citada a fonte - $O$ autor" 
Ao meu pai Waldomiro, com quem gostaria de compartilhar mais esta vitória, ofereço.

\footnotetext{
À minha mãe Silphe e minha irmã Anne, pela compreensão na ausência, pelo apoio, carinho e estímulo na distância, agradeço.
}

À Cristina, um agradecimento especial, quando convivemos com a distância e o trabalho, mas sem perder o carinho, o afeto e o amor. 


\section{AGRADECIMENTOS}

Ao Prof. Sérgio F. Pascholati, pela amizade, orientação, estímulo e experiência.

A Prof ${ }^{\mathrm{a}}$ Helaine Carrer, pela amizade e por ter aberto as portas de seu laboratório.

Ao Departamento de Fitopatologia e ao CEBTEC (ESALQ/USP), pela disponibilização dos laboratórios.

Aos colegas de trabalho e em especial aos integrantes dos laboratórios, pelo convívio acadêmico e lições aprendidas: Adriano Lucheta, Amaral, André, Clara, Eduardo, Elaine, Fátima, Irving, Leonardo, Nívea, Renata, Simone, Solange, Tercílio, e amigos. Um agradecimento especial ao amigo Robson, pelas sugestões na redação deste trabalho.

A PqC. Dra. Marli de Fiore (USP/CENA) pelo auxílio no desenho dos primers e fornecimento dos plasmídios.

A PqC. Dra. Maria Luiza Targon (CACSM-IAC) pelas sugestões e pela linhagens bacterianas.

Aos Prof. Dr. Luis E. A. Camargo, Augusto V. de O. Figueira e Luiz G. Prado Filho, pelas sugestões oriundas do exame de qualificação.

Aos funcionários e bibliotecária(o)s da USP.

A FAPESP, pela bolsa de estudos e auxílio financeiro, assim como pela iniciativa do Genoma funcional, cessão de informações e clones do Genoma Xylella. 


\section{SUMÁRIO}

Página

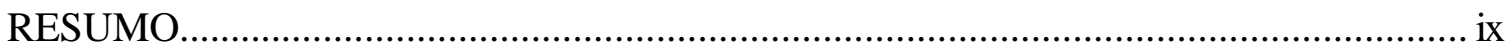

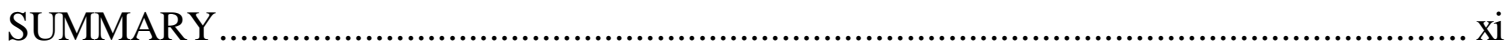

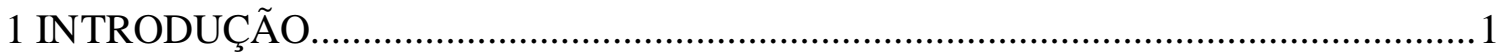

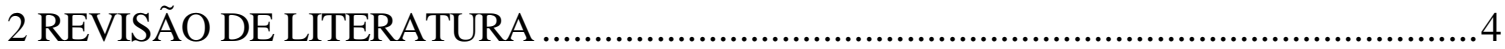

2.1 Clorose variegada dos citros e seu agente etiológico...............................................4

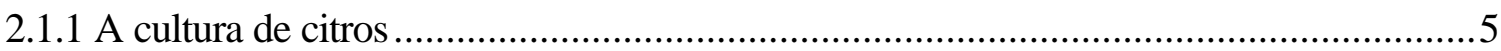

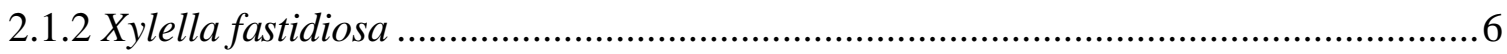

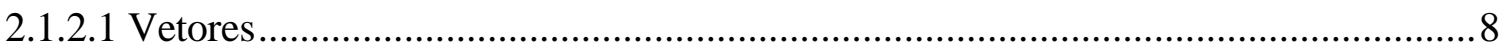

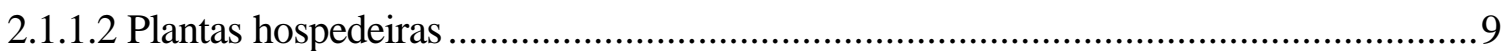

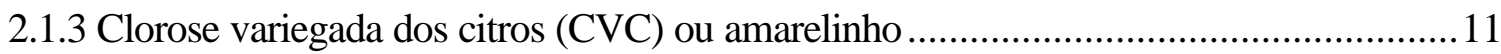

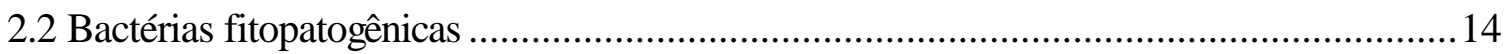

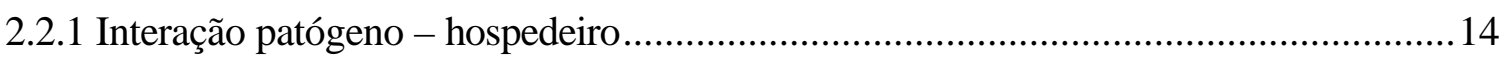

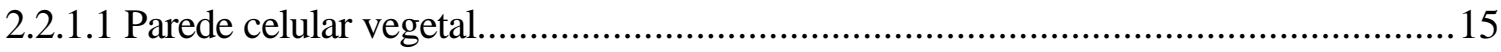

2.2.1.1.1 Componentes das paredes celulares vegetais................................................20

2.2.2 Mecanismos de patogenicidade / virulência ............................................................23

2.2.2.1 Enzimas degradadoras da parede celular vegetal (EDPCV) .................................26

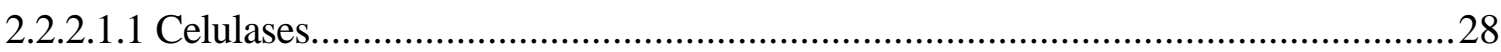

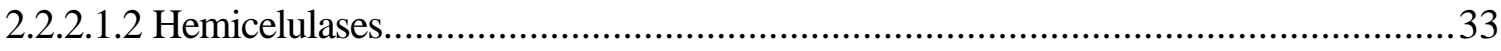

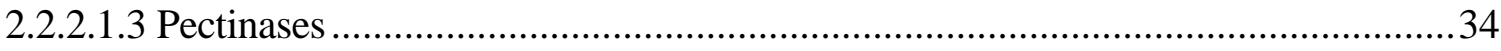

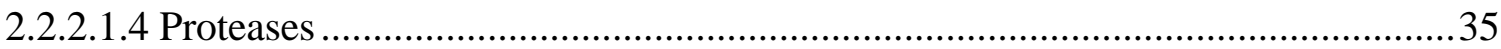

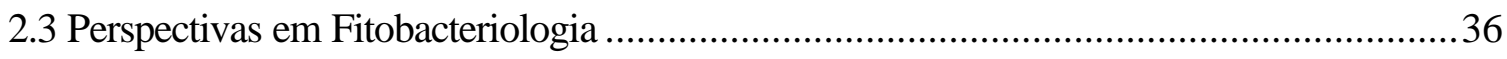

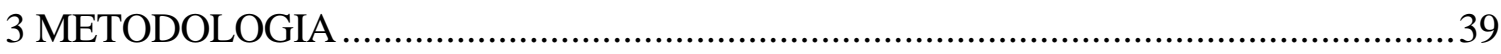

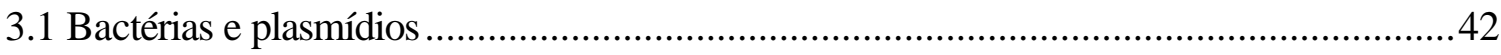

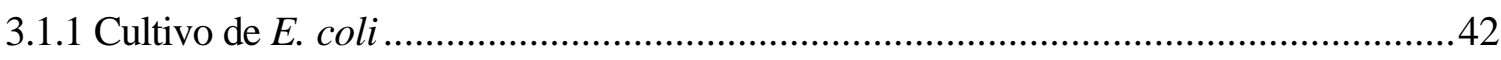

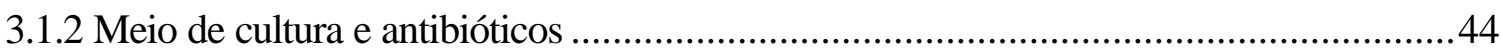


3.1.3 Extração de DNA cosmidial e plasmidial...............................................................45

3.2 Análise dos genes relacionados a celulases em $X$. fastidiosa ......................................46

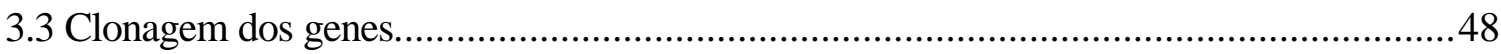

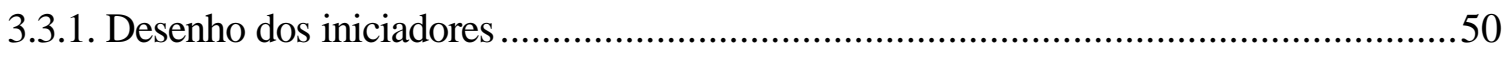

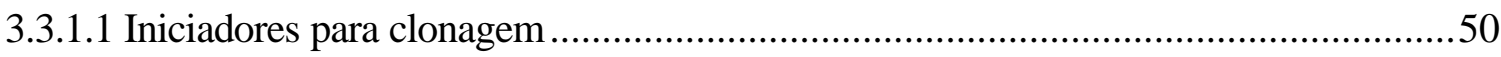

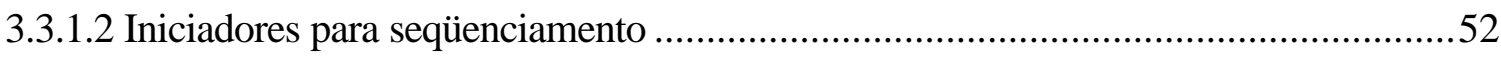

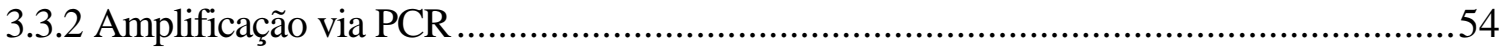

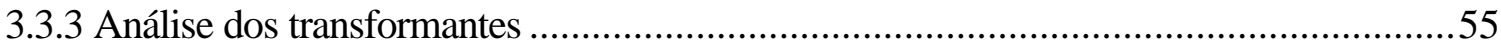

3.3.4 Clonagem dos genes Xf-810, Xf-818 e Xf-2708 no plasmídio de expressão pET20b56

3.3.4.1 Construção dos plasmídios para expressão das proteínas nativas ............................56

3.3.4.2 Construção de plasmídios para expressão de proteínas recombinantes com cauda hexahistidina na extremidade carboxila terminal.......................................5 58

3.3.5 Clonagem dos genes Xf-810 e Xf-818 no plasmídio de expressão pET28b...............61

3.3.6 Seqüenciamento dos genes clonados nos vetores de expressão .................................62

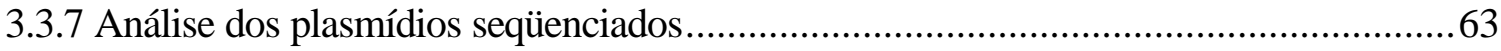

3.3.8 Transferência dos plasmídios para E. coli DH5 $\alpha$, BL21 ( $\lambda \mathrm{DE} 3)$ ou BL21 ( $\lambda \mathrm{DE} 3)$ pLysS 64

3.3.8.1 Transformação de células de E. coli ................................................................64

3.4 Expressão heteróloga das celulases nos plasmídios pET20b e pET28b........................ 66

3.4.1 Otimização da expressão das proteínas heterólogas em E. coli.................................66

3.4.1.1 Ensaio para endoglicanases em placa de petri...................................................67

3.4.1.2 Ensaio espectrofométrico indireto para endoglicanases ......................................68

3.4.1.3 Análise através de eletroforese desnaturante (SDS-PAGE) ................................70

3.4.1.4 Análise através de zimograma para celulase (CMC-SDS-PAGE) ..........................70

3.4.2 Tempo e temperatura de indução após a adição do indutor IPTG .............................71

3.5 Purificação das proteínas heterólogas expressas em $E$. coli .........................................72

3.5.1 Produção e extração de proteínas a partir das células de $E$. coli .................................72

3.5.2 Precipitação com sulfato de amônio ...................................................................... 73

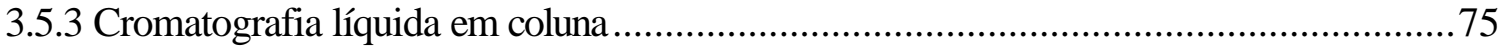

3.5.3.1 Cromatografia de afinidade em metal imobilizado (IMAC) ...................................76

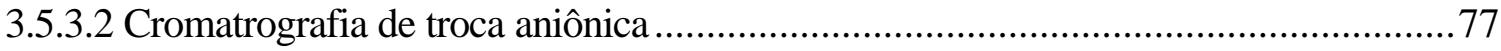


3.5.3.3 Cromatografia de filtração em gel........................................................................77

3.6 Caracterização enzimática das endoglicanases de X. fastidiosa ......................................78

3.6.1 Atividade endoglicolítica (celulase ou CMCase) sobre a carboximetil celulose ..............78

3.6.1.1 Determinação da atividade endoglicolítica em diferentes valores de $\mathrm{pH}$......................79

3.6.1.2 Determinação da atividade endoglicolítica em diferentes molaridades.........................79

3.6.1.3 Determinação da atividade endoglicolítica a diferentes tempos de incubação...............80

3.6.1.4 Determinação da atividade endoglicolítica sob diferentes temperaturas........................80

3.6.2 Degradação de polímeros pelas endoglicanases Xf-810, Xf-818 e Xf-2708 ...............80

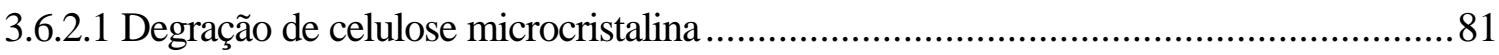

3.6.2.2 Hidrólise simultânea de CMC pelas endoglicanases de X. fastidiosa .........................82

3.6.3 Produção de oligômeros derivados da celulose e degradação de celo-oligossacarídeos

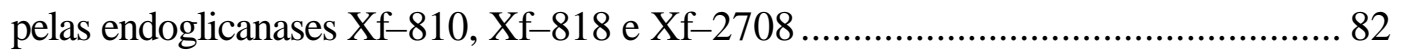

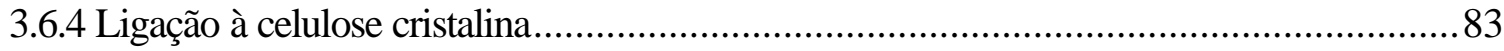

4 RESULTADOS

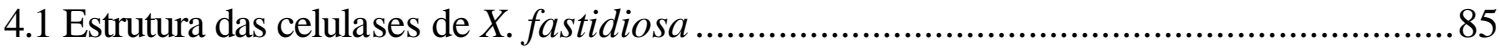

4.2 Clonagem dos genes da $X$. fastidiosa nos vetores de expressão.......................................8 88

4.3 Seleção dos clones e otimização da produção das proteínas heterólogas ..........................92

4.4 Expressão e purificação das proteínas heterólogas ………………………………..........98

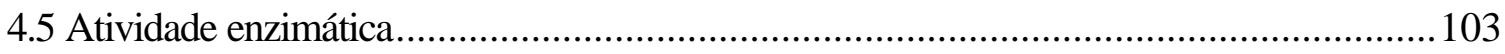

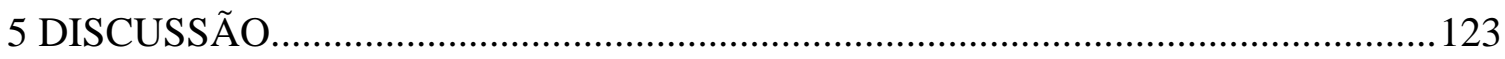

5.1 Clonagem dos genes nos vetores de expressão …………......................................... 123

5.2 Expressão das proteínas heterólogas.......................................................................124

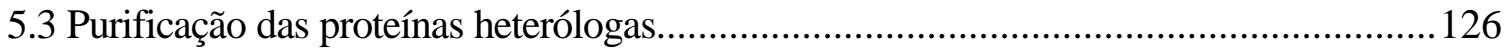

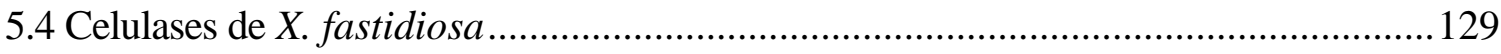

5.4.1 Características das proteínas ............................................................................130

5.4.2 Propriedades catalíticas...................................................................................139

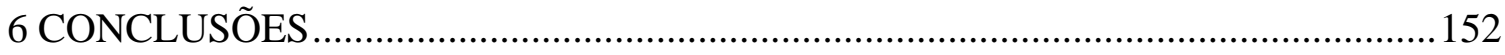

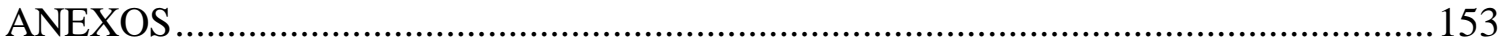

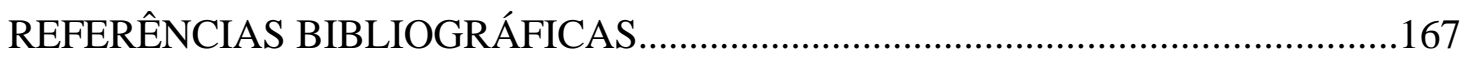

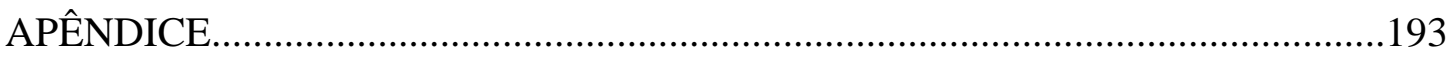




\section{CARACTERIZAÇÃO ENZIMÁTICA DAS CELULASES XF-810, XF-818 E XF-2708 DE Xylella fastidiosa E PURIFICAÇÃO DA PROTEÍNA XF-818, EXPRESSAS EM Escherichia coli}

Autor: NELSON ARNO WULFF

Orientador: Prof. Dr. SÉRGIO FLORENTINO PASCHOLATI

\section{RESUMO}

A bactéria Xylella fastidiosa causa a clorose variegada dos citros, também conhecida como amarelinho. Em 2000, foi concluído o seqüenciamento do genoma deste organismo, o primeiro de uma bactéria fitopatogênica, um fato que estimulou o estudo dos possíveis mecanismos de patogenicidade empregados pela bactéria para causar a doença em citros. X. fastidiosa é uma bactéria limitada ao xilema, sendo transmitida de planta a planta através de insetos vetores. Especula-se que a bactéria produza enzimas que degradem a membrana da pontuação, permitindo a colonização de novos vasos do xilema. A identificação de genes com similaridade de seqüência a genes de celulases, xilanases, pectinases e proteases, fomentou o presente estudo visando caracterizar os genes $\mathrm{Xf}-810, \mathrm{Xf}-818$ e Xf - 2708, similares a endoglicanases. Estes genes foram clonados em vetores de expressão e as respectivas proteínas foram produzidas em Escherichia coli. Através de ensaios enzimáticos as proteínas foram caracterizadas como endoglicanases (EC 3.2.1.4), que são celulases com mecanismo endoglicolítico de ataque às moléculas de celulose. Estas celulases hidrolisam carboximetil celulose, Avicel e xilana, enquanto as enzimas Xf - 810 e Xf - 818 hidrolisam a 
celulose amolecida com ácido. Estas celulases degradam mais eficientemente a carboximetil celulose em pH ácido (entre 5,2 e 5,6) e na temperatura de $65^{\circ} \mathrm{C}$. Coletivamente, estas celulases são capazes de degradar polímeros solúveis e insolúveis, enquanto a enzima Xf 818, é capaz de degradar oligossacarídeos derivados da celulose, como celotetraose e celopentaose, apresentando ampla variação catalítica. Esta celulase possui capacidade de ligação à celulose microcristalina, denotando a funcionalidade de seu domínio ligador de celulose. Desenvolvemos um protocolo, empregando cromatografia de troca aniônica, afinidade por metal (níquel) e filtração em gel, eficiente na purificação da proteína Xf - 818 expressa heterologamente em E. coli com fusão hexahistidina à extremidade $\mathrm{N}$-terminal. A caracterização enzimática destas proteínas, com a confirmação da atividade celulásica, fornece subsídios para uma eventual função das celulases durante a colonização do hospedeiro pela bactéria, pois são cataliticamente funcionais. Ademais, corrobora a similaridade destes genes, verificada durante o seqüenciamento do genoma de $X$. fastidiosa. 


\section{ENZYMATIC CHARACTERIZATION OF ENDOGLUCANASES XF-810, XF-818 AND XF-2708 FROM Xylella fastidiosa AND PURIFICATION OF PROTEIN XF-818 EXPRESSED IN Escherichia coli}

Author: NELSON ARNO WULFF

Adviser: Prof. Dr. SÉRGIO FLORENTINO PASCHOLATI

\section{SUMMARY}

Xylella fastidiosa is the causal agent of citrus variegated chlorosis, also known as "amarelinho". The recent sequencing of its genome, achieved in 2000, was the first of a plant pathogen, a fact that stimulated the search for putative pathogenicity factors employed by this bacterium while infecting citrus trees. X. fastidiosa inhabits exclusively the xylem vessels, being transmitted by sharpshooter vectors. Several authors argue that the bacterium produces enzymes to degrade plant cell, as a way to colonize new xylem vessels through pit membrane degradation. The identification of putative cellulases, xylanases, pectinases and proteases on $X$. fastidiosa genome, led us to carry out the present work to characterize the putative products of the endoglucanase genes $\mathrm{Xf}-810, \mathrm{Xf}-818$ and $\mathrm{Xf}-2708$. These genes were cloned into expression vectors and the proteins were produced in Escherichia coli. Based upon enzymatic assays, those proteins were characterized as endoglucanases (EC 3.2.1.4), which are cellulases able to promote the endo-hydrolysis of cellulose chains. These cellulases degraded carboxymethylcellulose, Avicel and xylan, while only Xf -810 and Xf -818 degraded acid swollen cellulose. The hydrolysis of carboxymethylcellulose was higher at acidic $\mathrm{pH}$ (between 5.2 and 5.6) and at a temperature of $65^{\circ} \mathrm{C}$. As a group, these enzymes were able to degrade 
soluble and insoluble cellulose derivatives, while only the cellulase Xf - 818 could hydrolyze the cello-oligosaccharides cellotetrose and cellopentose, thus showing a high catalytic diversity. This protein also has the capacity to bind microcristalline cellulose, confirming the presence of a functional cellulose-binding domain. We set a protocol, employing anion exchange, metal affinity and gel filtration chromatography, to purify the $\mathrm{Xf}-818$ enzyme expressed in E. coli as a $\mathrm{N}$-hexahistine fusion tag. The endoglucanase activity studied gives support for an eventual role of such cellulases during host colonization by the bacterium. Besides that, it agrees with similarities searches observed on the sequencing of $X$. fastidiosa genome. 


\section{INTRODUÇÃO}

Passados 10 anos desde a primeira constatação da clorose variegada dos citros - CVC no estado de São Paulo, a bactéria Xylella fastidiosa Wells foi escolhida como alvo do primeiro projeto de seqüenciamento completo no Brasil, uma tarefa executada por pesquisadores do projeto Genoma/ONSA, numa iniciativa da FAPESP. Em 2000, este trabalho foi concluído (Simpson et al., 2000) e representou um marco na história da pesquisa científica brasileira. Derivado do seqüenciamento do genoma da $X$. fastidiosa, surgiram iniciativas visando determinar a função dos genes putativamente encontrados na bactéria. A escolha de $X$. fastidiosa como alvo para seqüenciamento deu-se principalmente pela importância dos danos ocasionados pela bactéria à citricultura paulista. A citricultura representa uma grande fonte de recursos e responde por significativa parcela do produto interno bruto do estado.

A clorose variegada dos citros foi constatada pela primeira vez no estado de São Paulo em 1987 (Rossetti et al., 1990), disseminando-se por todo o país em poucos anos (Lee et al., 1991; Tubelis et al., 1993). A CVC tem sido considerada um dos fatores responsáveis pela retração na produtividade de cítricos no país e estimativas alarmantes indicavam uma derrocada da citricultura devido à elevada incidência de CVC a ser atingida (Gottwald et al., 1993). Uma doença muito semelhante, Pecosita, foi constatada no Paraguai (Segnana et al., 1998) e Argentina (Beretta et al., 1992; Contreras, 1992). Nestes anos muitas pesquisas foram conduzidas com o intuito de determinar as características do patógeno, identificar fontes de resistência nos hospedeiros, seu modo de transmissão e formas de controle. 
A interação patógeno - hospedeiro pode ser analisada sob aspectos morfológico, genético, bioquímico ou molecular, isoladamente ou em conjunto. Independente da abordagem ou estudo que seja efetuado, fica patente o papel dos fatores de patogenicidade que os patógenos, em particular as bactérias, empregam para colonizar o tecido hospedeiro e desenvolverem-se neste nicho. Uma grande parcela dos fatores de patogenicidade é formada pelas proteínas extracelulares produzidas pelas bactérias. Entre estas proteínas, muitas enzimas exercem uma função crucial, dependente de cada interação, é claro, no desenvolvimento do patógeno e conseqüente surgimento dos sintomas.

A análise de proteínas, mais especificamente de enzimas, de uma bactéria de crescimento lento como $X$. fastidiosa representa não somente um desafio, mas também um empecilho para se tentar entender o papel das exoenzimas na interação bactéria-planta. Entretanto, como sabemos que $X$. fastidiosa possui genes que apresentam similaridade com proteínas envolvidas na patogênese em outros patossistemas (Simpson et al., 2000), podemos utilizar a expressão heteróloga destes genes como uma forma de facilitar seu estudo.

X. fastidiosa coloniza os vasos xilemáticos, cujas paredes são compostas de celulose, hemiceluloses e pectinas, entre outros componentes e por onde circula a seiva bruta. Portanto, vem a ser uma hipótese plausível supor o envolvimento de enzimas que degradam os componentes da parede celular, durante a passagem de uma célula a outra, através da membrana da pontuação. Purcell \& Hopkins (1996) ponderam que a movimentação vaso a vaso pelas bactérias limitadas ao xilema sugere a produção de enzimas que degradam a membrana da pontuação. Entretanto, Hopkins (1985) não conseguiu evidenciar a produção de enzimas como celulases ou pectinases em cultura por $X$. fastidiosa causadora do mal de Pierce (X. fastidiosa PD). Embora diversos genes relacionados às enzimas que degradam componentes da parede celular vegetal tenham sido clonados e o seus produtos caracterizados em outras bactérias fitopatogênicas, quase nada é sabido destas enzimas em X. fastidiosa. Simpson et al. (2000) e também Lambais et al. (2000) e Dow \& Daniels (2000) fazem uma abordagem dos principais mecanismos de patogenicidade potencialmente empregados pela bactéria, embora o papel das exoenzimas não seja extensivamente explorado. 
Acreditamos que a presença de genes com alta similaridade às enzimas degradadoras da parede celular vegetal (EDPCV), como as endoglicanases, celobiohidrolase, endoxilanases, poligalacturonase e possível liase de pectato (embora com baixa homologia de sequiência), fornece o arsenal enzimático adequado para que esta bactéria possa degradar componentes das paredes celulares da planta hospedeira, notadamente a parede primária na membrana da pontuação. A reunião do hábito de colonizar o xilema, com a potencialidade enzimática da bactéria, fomentou o presente estudo com as celulases de X. fastidiosa. Assim, nossos objetivos no presente trabalho foram os de clonar e expressar sequiências relacionadas às endoglicanases de $X$. fastidiosa em Escherichia coli e caracterizar estas enzimas quanto a sua atividade catalítica. 


\section{REVISÃO DE LITERATURA}

\subsection{Clorose variegada dos citros e seu agente etiológico}

A clorose variegada dos citros ou CVC foi constatada pela primeira vez no estado de São Paulo em 1987 (Rossetti et al., 1990), disseminando-se por todo o país em poucos anos (Lee et al., 1991; Tubelis et al., 1993). A CVC tem sido considerada um dos fatores responsáveis pela retração na produtividade de cítricos no país e estimativas alarmantes indicavam uma derrocada da citricultura devido à elevada incidência de CVC a ser atingida (Gottwald et al., 1993).

A identificação do agente etiológico da CVC, a bactéria $X$. fastidiosa, foi feita por Rossetti et al. (1990) e Chagas et al. (1992). Os postulados de Koch foram cumpridos por Chang et al. (1993) e Lee et al. (1993). Neste período, relativamente curto na ocorrência de uma doença, mas grande devido às proporções que atingiu, muitos estudos foram efetuados para compreender o patossistema. O mais noticiado de todos foi o seqüenciamento do genoma da X. fastidiosa (Simpson et al., 2000), com todas as suas ramificações, como os projetos Genoma Funcional derivados, no qual o presente trabalho se insere.

A despeito da grande quantidade de trabalhos visando caracterizar os aspectos fitopatológicos da CVC, como vetores e hospedeiros da bactéria, sintomatologia e controle da doença, só recentemente a bactéria passou a ser alvo de intensa pesquisa. Isto fica evidente nos recentes relatos da transformação genética de diferentes linhagens de X. fastidiosa. Qin \& Hartung (2001) relatam a utilização de um plasmídio críptico para a construção de um vetor e subseqüente transformação de uma linhagem de $X$. fastidiosa de citros. Monteiro et al. (2001b) relatam pela primeira vez a transformação estável da X. fastidiosa de citros, através 
de recombinação homóloga, utilizando um plasmídio com a origem de replicação cromosomal (oriC) de $X$. fastidiosa. Guilhabert et al. (2001) conseguiram efetuar a transformação da $X$. fastidiosa de uva empregando o transposon Tn5, o que permite a geração de um grande número de mutantes. Estes recentes relatos da transformação de $X$. fastidiosa, um organismo até então considerado recalcitrante para transformação, permitem a análise genética detalhada das funções dos genes com a geração de mutantes defectivos em diversos processos. Além disso, avanços importantes foram feitos quanto à utilização de hospedeiros alternativos da $X$. fastidiosa de citros, como fumo (Nicotiana tabacum) (Lopes et al., 2000) e vinca (Catharanthus roseus) (Monteiro et al., 2001a). Entretanto, em fumo os sintomas são distintos dos característicos sintomas de clorose observados em citros e em vinca (Rossetti et al., 1990; Monteiro et al., 2001a), surgindo como pequenas lesões laranja-escuro que podem coalescer em folhas mais velhas. Estes hospedeiros alternativos ou experimentais podem facilitar o estudo da interação Xylella-planta e Xylella-vetor-planta.

\subsubsection{A cultura de citros}

A quantidade de laranja produzida no Brasil tem variado entre 104 e 115 bilhões de frutos/ano entre 1996 e 2000, valor que convertido em reais gira em torno de 1,1 a 1,5 bilhões de dólares/ano (IBGE, 2002). O estado de São Paulo e o estado da Flórida (EUA) são as principais áreas citrícolas do mundo. Em 2000, a área destinada a citricultura foi de 857 mil ha no Brasil, sendo cerca de 630 mil ha em São Paulo, com 164 milhões de laranjeiras, onde foram produzidas anualmente 374 milhões de caixas de laranja, correspondendo a cerca de $87 \%$ da produção nacional e a $30 \%$ da mundial.

Segundo Laranjeira (2002), a base monocultural da citricultura paulista é o fator isolado mais importante para o aparecimento e avanço de uma série de doenças, como sorose, exocorte e tristeza, todas com elevada taxa de disseminação através de material propagativo. Neste contexto, a CVC tornou-se a mais importante doença citrícola da 
atualidade no Brasil. Todas as cultivares comerciais de laranja doce são afetadas pela CVC, independente do porta-enxerto utilizado (Carvalho et al., 1995).

\subsubsection{Xylella fastidiosa}

Xylella fastidiosa foi descrita por Wells et al. (1987) e apresenta como bactéria tipo um isolado obtido de videira com a doença de Pierce. A etiologia desta doença foi inicialmente associada a vírus, posteriormente a relação causal foi associada com organismos do tipo Rickettsia, mais tarde denominados de bactérias limitadas ao xilema. Finalmente em 1987, Wells e colaboradores (Wells et al. 1987), criaram o gênero Xylella, com a espécie $X$. fastidiosa, uma bactéria relacionada ao gênero Xanthomonas.

Segundo Holt (1994), X. fastidiosa é caracteristicamente um bastonete, Gramnegativa, atríquia, estritamente aeróbia, não fermentativa, não halofílica, apigmentada, com temperatura ótima de desenvolvimento de 26 a $28{ }^{\circ} \mathrm{C}$ e pH ótimo de 6,5 a 6,9. Suas dimensões são de 0,25 a $0,35 \mu \mathrm{m}$ de largura por 0,9 a 3,5 $\mu \mathrm{m}$ de comprimento, com a colônia podendo ser de dois tipos: convexa, margem lisa e uniforme, coloração leitosa ou com irregularidades no centro e margem levemente ondulada. Tem capacidade para hidrolisar gelatina, não fermenta a glicose, apresenta reação negativa para os testes de indol, $\mathrm{H}_{\mathbf{L}} \mathrm{S}, \beta$ galactosidase, lipase, amilase, coagulase e fosfatase. A maioria das linhagens produzem $\beta$ lactamase. Uma característica particular é a presença de uma parede celular ondulada ou crenulada (Fry \& Milholland, 1990b; Chagas et al., 1992).

A grande diversidade na gama de hospedeiros de $X$. fastidiosa (ver item 2.1.1.2) pode refletir-se ou ser reflexo, de elevada diversidade genética entre isolados do patógeno. Diversos autores desenvolveram técnicas de diagnose através de PCR (Beretta et al., 1997; Minsavage et al., 1994; Pooler \& Hartung, 1995). Inclusive no trabalho de Ferreira et al. (2000), o produto amplificado é específico para linhagens de X. fastidiosa obtidas de citros e cafeeiro. Wendland (2000), utilizando marcadores moleculares RAPD, observou que na região noroeste de SP (Neves Paulista), a população da bactéria é composta por mais de 15 haplótipos, enquanto na região central há predominância de um haplótipo e na região sul 
ocorrem predominantemente três haplótipos. Foi observado que a linhagem de X. fastidiosa 9a5c com genoma seqüenciado (Li et al., 1999; Simpson et al., 2000), apresentou perfil distinto dos demais isolados de citros no trabalho de Wendland (2000), indicando que a estirpe é rara ou não ocorre nas regiões estudadas. De qualquer maneira, este isolado 9a5c é patogênico em Citrus sinensis (L.) Osbeck, como observado por Li et al. (1999), após a $8^{\text {a }}$ passagem (utilizado no seqüenciamento) ou após a $16^{\mathrm{a}}$ passagem (clone do isolado 8.1.b, coletado em São Paulo e primeiro isolado com o qual confirmaram-se os postulados de Koch como agente causal da CVC - Chang et al. 1993).

Simpson et al. (2000) relatam que a porcentagem de orfs (quadro aberto de leitura - "open reading frames") com função putativa, cerca de $47 \%$, pode refletir a baixa quantidade de seqüências com funções conhecidas em bactérias fitopatogênicas. Este dado fica mais evidente devido à ausência, em $X$. fastidiosa, de seqüências com similaridade aos genes avr e hrp, amplamente estudados, principalmente em Xanthomonas spp., que são bactérias proximamente relacionadas. Entretanto, a constante caracterização genética e funcional de novos genes e genomas deverá adicionar função às orfs desconhecidas ou com baixa homologia. Um exemplo disto é o caso do plasmídio pXF51 da própria $X$. fastidiosa, onde recentemente foi descrita uma nova orf que apresenta similaridade com proteínas envolvidas em conjugação (http://aeg.lbi.ic.unicamp.br/xf/).

Na linhagem de $X$. fastidiosa patogênica à videira, a virulência dos isolados PD (Pierce Disease) foi determinada pela habilidade dos mesmo em atingir um limiar de população próxima a $10^{6} \mathrm{ufc/cm}$ nos pecíolos (Hopkins, 1985). Linhagens virulentas infestam 10 vezes mais os vasos xilemáticos do que isolados avirulentos. Hopkins (1985) concluiu que a ausência de virulência dos isolados PD resulta da incapacidade em multiplicar-se e de mover-se sistemicamente no hospedeiro suscetível. Embora o autor não tenha detectado a produção de celulases ou pectinases por $X$. fastidiosa PD, estas enzimas podem ser produzidas quando em contato com as células vegetais ou sob outras condições específicas.

He et al. (2000) observaram que $X$. fastidiosa transloca-se da parte aérea para o sistema radicular e também demonstraram, pela primeira vez, que a bactéria causadora 
da CVC pode ser transmitida pela enxertia natural de raízes de laranjeira. Almeida et al. (2001) isolaram colônias de $X$. fastidiosa em amostras coletadas $4 \mathrm{~cm}$ acima e $4 \mathrm{~cm}$ abaixo do ponto de inoculação no caule de laranja doce, uma semana após a inoculação. Os autores comentam que a distribuição irregular do patógeno no estágio inicial de infecção, com baixa população bacteriana, é um fator que pode interferir na baixa taxa de aquisição e /ou transmissão da bactéria pelos vetores. Além da detecção da bactéria abaixo do ponto de inoculação, folhas com sintomas foram observadas abaixo deste local. Almeida et al. (2001) também concluem que o número de colônias recuperadas de citros é menor que o obtido em videira. Mizubuti et al. (1994) observaram que somente de 5 a $10 \%$ dos vasos xilemáticos de folhas sintomáticas de laranja doce estavam colonizados por X. fastidiosa, um fato que corrobora a menor proporção de colonização do xilema e a baixa eficiência de transmissão por espécies vetoras. A observação da transmissão de $X$. fastidiosa através de enxertia natural de raízes (He et al., 2000) pode também constituir um fator a ser considerado na transmissão da $X$. fastidiosa em cafeeiro, ou até entre cafeeiro e citros, visto que a linhagem causadora de CVC pode causar requeima do cafeeiro (Li et al., 2001). Em videira, Fry \& Milholland (1990a) determinaram que a bactéria é translocada pela planta de maneira similar entre cultivares resistente e suscetível, entretanto, é detectada em níveis muito mais baixos na planta resistente quando comparada com a planta suscetível.

Podemos esperar um período de grandes descobertas em relação à biologia e patogenicidade de $X$. fastidiosa, fomentados pelo seqüenciamento completo do genoma da bactéria, pelas recentes metodologias de transformação da bactéria e pela necessidade inerente de estudo desta bactéria de grande importância econômica.

\subsubsection{Vetores}

A transmissão de $X$. fastidiosa ocorre através de cigarrinhas da família Cicadellidae, subfamília Cicadellinae e Cercopidae, que se alimentam da seiva bruta das plantas (Purcell \& Hopkins, 1996). Em citros, Rossetti et al. (1995) apresentaram as primeiras 
evidências da transmissão de $X$. fastidiosa por vetores, observando a incidência da CVC em plantas de laranja Natal não protegidas por telado.

A transmissão da bactéria causadora da CVC pelas espécies de cigarrinhas mais abundantes em citros foi determinada por Lopes (1996). Atualmente são descritas 11 espécies transmissoras do patógeno, incluindo Acrogonia virescens, A. citrina, Bucephalogonia xanthopis, Dilobopterus costalimai, Ferrariana trivittata, Homalodisca ignorata, Macugonalia leucomelas, Oncometopia facialis, Parathona gratiosa, Plesiommata corniculata e Sonesimia grossa (Fundecitrus, 2002; Krügner et al., 1998; Roberto et al., 1996; Yamamoto et al., 2000), além das espécies vetoras em potencial Hortensia similis e Macugonalia cavifrons (Fundecitrus, 2002). Krügner et al. (1998) avaliaram a eficiência de transmissão de X. fastidiosa pelos vetores $O$. facialis, Acrogonia sp., P. corniculata, D. costalimai e B. xanthophis, e encontraram eficiência de transmissão baixa, de 1,3 - 2,3 - 2,9 - 5,5 e 11,7\%, respectivamente. Esta taxa de transmissão está bem abaixo da relatada para o vetor de X. fastidiosa PD, Graphocephala atropunctata que é superior a $90 \%$ (Purcell \& Finlay, 1979). Pereira (2000) observou que a espécie vetora $D$. costalimai é a predominante na região sul, enquanto Acrogonia sp. predomina nos pomares das regiões noroeste e central.

\subsubsection{Plantas hospedeiras}

Quase todas as espécies do gênero Citrus são suscetíveis à colonização de $X$. fastidiosa e surgimento de sintomas da CVC. Laranjas doces $(C$. sinensis $)$, tangerinas $(C$. reticulata), tangores (C. reticulata $\mathrm{x} C$. sinensis), tangelos $(C$. reticulata $\mathrm{x} C$. paradisi) $\mathrm{e}$ lima ácida Taiti (C. latifolia) podem apresentar sintomas de CVC. Árvores de outros gêneros da família Rutaceae e relacionados ao Citrus, como Fortunella e Poncirus, não são sintomáticas e não apresentam a bactéria $X$. fastidiosa em seus tecidos em condições de transmissão natural (Laranjeira et al., 1998). Todas as cultivares comerciais de laranja doce são afetadas pela CVC independentemente do porta-enxerto utilizado. Não foram observados sintomas em mandarinas, murcott, limões verdadeiros e em lima ácida Galego (Carvalho et al., 
1995). As laranjas doces são os hospedeiros mais suscetíveis a X. fastidiosa, embora com diferenças acentuadas em relação à suscetibilidade. Tangerina e seus híbridos, como tangores e tangelos, podem apresentar sintomas em condições de campo, restritos às folhas, embora numa intensidade bem menor que nas laranjas doces. Nas variedades de maior valor econômico, como Ponkan, Cravo e Murcote, constatou-se apenas a presença da bactéria quando sobreenxertadas em plantas de laranja doentes (Machado et al., 1987). Em condições de transmissão natural, a bactéria nunca foi detectada nos tecidos dessas tangerinas ou nos da Mexirica (Laranjeira, 1997). Em lima ácida Tahiti, a bactéria nunca foi detectada no clone de Tahiti mais plantado em São Paulo, o IAC 5 (Laranjeira, 2002).

Laranjeira (1997) apontou as épocas de maior progresso da CVC ocorrendo na primavera e no verão, as quais além de serem as épocas de maior expressão dos sintomas, também corresponderiam aos períodos de maior probabilidade de infecção. Pereira (2000) demonstrou que as inoculações mecânicas realizadas no verão ( dezembro e fevereiro) resultaram num maior número de plantas com sintomas, quando comparadas com as realizadas em maio e setembro. Gottwald et al. (1993) e Laranjeira (1997) sugerem uma associação de vetores com limitada dispersão aérea no arranjo e na dinâmica espacial das plantas com CVC. Laranjeira (1997) concluiu que havia agregação de plantas doentes e uma tendência de sua localização nos bordos dos talhões, notadamente quando na vizinhança de outros talhões contaminados.

A bactéria $X$. fastidiosa causa doenças em diversas culturas, como o mal de Pierce em videira - Vitis sp. (Davis et al., 1980), "phony peach" em pessegueiro - Prunnus sp. (Wells et al., 1981), escaldadura das folhas em ameixeira (Raju et al., 1982; French \& Feliciano, 1982), clorose variegada dos citros - Citrus sp. (Rossetti et al., 1990; Chang et al., 1993) e requeima do cafeeiro - Coffea arabica (Beretta et al., 1996; Paradela Filho et al., 1995). Foi diagnosticada também em alfafa - Medicago sativa (Goheen et al., 1973), pereira (Leu \& Su, 1993), nogueira pecã - Carya illinoinensis (Sanderlin \& Heyderich-Alger, 2000) e em plantas de 28 famílias de mono e dicotiledôneas (Freitag, 1951; Hopkins, 1989; Wells et al., 1987). Li et al. (2001) demonstraram que cafeeiro 'Mundo Novo' inoculado 
mecanicamente com $X$. fastidiosa de citros desenvolveu sintomas foliares, desfolha e redução do tamanho dos internódios, sendo caracterizada como patogênica àquela cultura. Este último fato pode demonstrar grande importância epidemiológica na dispersão de $X$. fastidiosa entre cafeeiros e plantas cítricas.

Mudas infectadas também podem disseminar o patógeno, entretanto a transmissão de $X$. fastidiosa através de instrumentos cortantes ou por sementes ainda não foi constatada (Sugimori et al., 1995). Entretanto, He et al. (2000) demonstraram que $X$. fastidiosa pode ser transmitida por enxertia natural de raízes.

Entre as diversas plantas invasoras, Lolium multiflorum (azevém), Digitaria sp. (capim colchão), Richardia sp. (poaia branca) e Taraxacum officinale (dente-de-leão) são descritas como hospedeiras (Leite et al., 1997; Travensolo \& Leite, 1996). Como $X$. fastidiosa foi observada em vegetais de ocorrência natural no Brasil e na Flórida (Hopkins \& Adlerz, 1988), a ocorrência de hospedeiros nativos no ambiente parece ser comum. No Brasil, além de cafeeiro e citros, X. fastidiosa foi observada em ameixeira (Kitajima et al., 1981), em hibisco (Hibiscus schizopetalus) (Kitajima et al., 2000) e em seringueira (Hevea brasiliensis) (Fonseca et al., 2001). Fica evidente diante do exposto, que a gama de hospedeiros de $X$. fastidiosa é grande e diversa.

\subsubsection{Clorose variegada dos citros (CVC) ou amarelinho}

A doença recebeu o nome de clorose variegada dos citros, devido aos sintomas foliares que são caracterizados por manchas cloróticas na superfície superior da folha e por pequenas pontuações de coloração marrom, semelhante à exsudação de goma, na superfície inferior correspondente da folha (Rossetti \& De Negri, 1990).

Os primeiros sintomas da CVC são observados nas folhas, em apenas um ou poucos ramos afetados, na parte média ou superior da planta. Os sintomas foliares podem ser caracterizados pela área foliar reduzida com manchas cloróticas esparsas, de formato irregular e localizados, majoritariamente próximas às bordas do limbo. Mancha cloróticas são 
observadas na face adaxial do limbo, correspondendo a manchas amarronzadas na face abaxial (Queiroz-Voltan \& Paradela Filho, 1999). Com o aumento na intensidade dos sintomas, estes surgem nos frutos de ramos afetados, podendo atingir a planta inteira. A produção é diminuída em termos de peso e número de frutos. As plantas, quando muito afetadas, apresentam um aspecto de debilidade geral, denotado pela coloração amarelada e redução de crescimento. Com o agravamento dos sintomas, as folhas mais velhas murcham e morrem, com a conseqüente desfolha e morte de ramos ponteiros. Os ramos afetados têm, comumente, entrenós encurtados não raro dando um aspecto de superbrotamento ao ramo. Observa-se também que as gemas dos ramos afetados tendem a brotar com uma frequiência maior que a observada nos sadios (Machado et al., 1992; Amorim et al., 1993; Laranjeira, 1997). De acordo com Machado et al. (1992), os sintomas mais característicos são observados em folhas maduras e podem ser de três tipos: clorose internerval típica de deficiência de zinco afetando todo o limbo; clorose pontuada de distribuição ao acaso, bastante parecida com picadas de insetos; ou clorose contínua e restrita a algumas áreas da folha.

Relacionando os sintomas das doenças causadas por $X$. fastidiosa com alterações na fisiologia do hospedeiro, há indícios da interferência no transporte de água e nutrientes nos vasos do xilema, que são bloqueados por células bacterianas, tiloses e gomas (Hopkins, 1989), desbalanço hormonal (French \& Stassi, 1978) e possível produção de fitotoxinas (Lee et al., 1982). Os sintomas da doença podem ser confundidos com estresse hídrico ou deficiências nutricionais, manifestando-se somente nos ramos, em folhas e nos frutos, enquanto as raízes não apresentam qualquer anormalidade (Malavolta et al., 1990). Malavolta et al. (1990) não conseguiram apontar o desarranjo nutricional como causa da CVC e Laranjeira (1997) ressalta que, embora seja comum a presença de desequilíbrios nutricionais, eles não se constituem em sintomas específicos ou fases do sintoma típico.

Nos frutos ocorre acentuada redução no tamanho, endurecimento da casca, aparente deficiência de potássio, com amarelecimento precoce, desenvolvimento de vários frutos por ramo e surgimento de lesões marrom-escuras (queimaduras causadas pelo sol). A qualidade dos frutos é comprometida devido ao endurecimento e redução acentuada do seu 
tamanho, tornando-os impróprios tanto para o comércio "in natura” quanto à extração do suco. Estes frutos podem causar danos às máquinas de moagem das fábricas de suco concentrado. Os sintomas são classificados em dois níveis: nível 1, quando as plantas de citros apresentam sintomas apenas nas folhas e nível 2, quando são observados frutos de tamanho reduzido nas plantas (Fundecitrus, 2002).

Laranjeira (1997) considera o inóculo gerado dentro do pomar o principal responsável pelo progresso da doença (autoinfecção). Amaro \& Maia (1997), observaram que a doença está espalhada por toda a região citrícola do estado de São Paulo e que é mais grave na região norte quando comparado à região sul do parque citrícola. Este dado é interessante, pois Wendland (2000) observou maior diversidade genética através de marcadores RAPD justamente no conjunto de isolados de $X$. fastidiosa isolados de plantas desta região. Laranjeira (2002) observou que de uma maneira geral são observadas mais similaridades do que diferenças entre os talhões estudados nas regiões norte, centro e sul (regiões citrícolas no estado de SP). Plantas afetadas pela CVC localizam-se próximas a outras também doentes, podendo ser caracterizado um padrão levemente agregado.

Medidas de controle atualmente empregadas consistem na utilização de mudas livres do patógeno, monitoramento da população de cigarrinhas com a aplicação de inseticidas e poda de ramos doentes (Donadio \& Moreira, 1997). Até o momento não se conhece nenhuma variedade ou clone de laranja doce resistente a X. fastidiosa. Os tangelos, híbridos altamente resistentes, são muito promissores como fontes de resistência (Laranjeira, 2002).

Em levantamento efetuado no ano de 2002 pela Fundecitrus (Fundecitrus, 2002) para avaliar a incidência de CVC na região nobre da citricultura (SP e parte do triângulo Mineiro) foram observados $10,36 \%$ das plantas com sintomas restritos às folhas e $27,92 \%$ das plantas com sintomas foliares e frutos miúdos, totalizando $38,28 \%$ de plantas afetadas. Deste total, a maior incidência está localizada na região Norte (região de Bebedouro e Barretos) com 55,59 \%, seguido da região Noroeste (região de São José do Rio Preto e Votuporanga) com 41,31 \%. Na região central (Araraquara e Matão), a incidência está na média, com 38,82 \% e na região sul (Limeira e Itapetininga) observou-se a menor incidência, 
de 16,09\%. Entre 1996 e 2002, a incidência da CVC sofreu variações, estabilizando ao redor de $36 \%$, nível observado em 2001, mas a severidade dos sintomas tem aumentado gradualmente. O número de plantas com sintomas nas folhas e frutos miúdos (nível 2), passou de 6,17\% em 1996 a 27,92\% em 2002.

\subsection{Bactérias fitopatogênicas}

A grande diversidade de bactérias que causam doenças em plantas, incluindo espécies Gram-positivas e negativas, o elevado número de patovares e raças, torna a tarefa de descrever os mecanismos de patogenicidade e virulência nas bactérias fitopatogênicas uma árdua tarefa. Estas bactérias pertencem majoritariamente aos gêneros Agrobacterium, Clavibacter, Erwinia, Leifsonia, Pseudomonas, Ralstonia, Streptomyces, Xanthomonas e Xylella. A sintomatologia observada, como murcha, podridão, amarelecimento, cancro, necrose, manchas foliares e tumores é característico do patossistema em questão e representa o resultado da interação dos mecanismos de patogenicidade da bactéria e as defesas da planta.

\subsubsection{Interação patógeno - hospedeiro}

O patógeno bacteriano é geralmente considerado um invasor passivo e incapaz de desenvolver força física para romper as forças estruturais do hospedeiro. Assim, se o patógeno depende de enzimas ou outros metabólitos em sua patogênese, uma produção adequada destes é necessária. Esta produção naturalmente depende de um grande número de células bacterianas (Goodman et al., 1986). Deste fato derivam dois pontos. Um, para que as bactérias possam causar doenças é essencial que colonizem um ambiente que favoreça sua multiplicação. Outro, a produção de fatores de virulência deve ser controlada, de maneira a ser produzido quando um número suficiente de bactérias esteja presente nos tecidos do hospedeiro. Deste segundo fator deriva o conceito de "sensor quorum" em bactérias fitopatogênicas (Pierson et al., 1998). Assim, as bactérias crescendo num ambiente favorável, 
atingem uma população grande o suficiente para empregar seus mecanismos de virulência e colonizar o tecido vegetal de forma conjunta e eficiente. Fica evidente que as bactérias percebem fatores ambientais diversos e somente dispendem energia de uma forma estritamente controlada, otimizando sua sobrevivência. Concomitantemente no hospedeiro, alterações decorrentes do crescimento do patógeno, bem como respostas de defesa ao patógeno são desenvolvidas.

Podemos encontrar muitos relatos na literatura do envolvimento de toxinas e exoenzimas no desenvolvimento da bactéria e conseqüente surgimento de sintomas, bem como a função de polissacarídeos extracelulares, hormônios e sideróforos com papel preponderante em interações específicas. Os produtos gênicos $a v r$ e $h r p$ são muito estudados como fatores intimamente relacionados à especificidade patógeno-hospedeiro, e a importância do sistema Hrp na resposta de defesa é conhecida. No caso específico de Agrobacterium tumefaciens, a seqüência de eventos celulares que conduz à formação de tecido hiperplásico é detalhadamente conhecida. Podemos considerar estes os fatores de virulência clássicos. Estes são os fatores de virulência usualmente estudados, mas a presença destes não exclui a possibilidade de outros fatores serem essenciais para a colonização bacteriana e o desenvolvimento de sintomas. Analisando detalhadamente os trabalhos que descrevem estes fatores e a patogênese bacteriana, observamos que raramente são estudados em conjunto, de forma a explicar de uma maneira holística como as bactérias causam doenças em plantas.

\subsubsection{Parede celular vegetal}

Em todas as paredes celulares vegetais existem duas camadas: a lamela média (substância intercelular) e a parede primária. Inúmeras células depositam uma camada parietal adicional, a parede secundária. A lamela média situa-se entre as paredes primárias de células adjacentes e a parede secundária, se presente, sendo depositada pelo protoplasto sobre a superfície interna na parede primária (Figura 1) (Raven et al., 1976). 
A lamela média compõe-se principalmente de substância pécticas (Tabela 1) e freqüentemente é difícil distinguí-la da parede primária, principalmente nas células que formam paredes secundárias grossas (Raven et al., 1976).

A camada parietal depositada antes e durante o crescimento da célula chamase de parede primária. Muitas células são formadas única e exclusivamente pela parede primária. Esta camada, além da celulose, contém hemicelulose, pectina (Figura 2) e proteínas ricas em hidroxiprolina. Células em divisão ativa comumente contêm apenas paredes primárias, assim como a maioria das células maduras que realizam processos como fotossíntese, respiração e secreção. As paredes primárias, de um modo geral, não são uniformes na espessura em toda a sua extensão. Áreas mais finas, ditas campos primários de pontuação estão presentes. Nestes campos pontuados é comum a presença de filamentos citoplasmáticos, ou plasmodesmatas, intercomunicando os protoplastos vivos de células adjacentes (Raven et al., 1976).

Em determinados tipos celulares, o protoplasto segrega uma parede secundária por dentro da primária. Na grande maioria dos casos, isso acontece depois que o crescimento celular cessou e a parede primária não amplia mais a sua área. Freqüientemente, o protoplasto morre em seguida à deposição da parede secundária. A celulose é mais abundante nas paredes secundárias do que nas paredes primárias, sendo aquelas portanto mais rígidas. Nas paredes secundárias podem ser distinguidos três estratos, diferindo na orientação das sua fibrilas celulósicas (Figura 1), o que confere maior rigidez e resistência a esta parede. Nas células condutoras e de sustentação, a parede secundária estabelece-se somente sobre uma parte da parede primária, revestindo-a na forma de anéis, hélices ou rede, não cobrindo também os campos pontuados primários da parede primária, do que decorrem as características depressões ou pontuações (Figura 1).

Em uma célula, uma pontuação habitualmente ocorre em oposição à pontuação da célula com a qual está em contato (Figura 1). A lamela média e as duas paredes primárias, situadas entre as duas pontuações, denominam-se membrana da pontuação. As duas pontuações opostas, associadas à membrana, constituem um par pontuado, o qual pode ser 
simples ou areolado (com a parede secundária curvada sobre a cavidade da pontuação). Os plasmodesmatas, comunicações citoplasmáticas entre células adjacentes, ocorrem em toda a parede celular ou agregados nos campos pontuados primários ou nas membranas situadas entre os pares de pontuações (Raven et al., 1976).

O xilema exerce funções de sustentação, condução de água e sais minerais e armazena substâncias alimentares. As células condutoras de água do xilema são os membros dos vasos (ou elementos do vasos) e as traqueídes, que são células alongadas com paredes secundárias. Os membros dos vasos apresentam perfurações, podendo ser na forma de placa perfurada, terminais e em alguns casos laterais. Os traqueídes apresentam somente pontuações. Durante os estágios finais de diferenciação, as pontuações são parcialmente hidrolisadas, restando apenas uma rede altamente permeável de microfibrilas de celulose (Raven et al., 1976).

O mais característico dos componentes da parede celular vegetal é a celulose, que constitui grande parte da estrutura parietal. As moléculas de celulose estão unidas em microfibrilas. Estas microfibrilas por sua vez, formam delgados filamentos ou fibrilas que podem enrolar-se em torno umas das outras, formando uma macrofibrila com até 500 mil moléculas de celulose e propriedades. As fibras celulósicas da parede acham-se em uma matriz reticulada de moléculas não-celulósicas, as hemiceluloses e substância pécticas. A lignina é um dos constituintes mais importantes da parede secundária, sendo rígido. Caracteristicamente, a lignificação começa na lamela média, depois espalha-se pela parede primária e finalmente atinge a parede secundária (Raven et al., 1976). 
Tabela 1. Principais componentes da parede celular vegetal ${ }^{1}$.

\begin{tabular}{|c|c|c|c|}
\hline Componente & $\begin{array}{l}\text { Localização e } \\
\% \text { em massa }\end{array}$ & $\begin{array}{l}\text { Principa is radicais } \\
\text { (quantidade) }\end{array}$ & Principais componentes e função \\
\hline Celulose & $\begin{array}{l}\text { Paredes primária e } \\
\text { secundária; } 35 \%\end{array}$ & Glc $\beta-(1,4)$ & $\begin{array}{l}\text { Cadeias longas de glicose. Menos polimerizada na parede } \\
\text { primária (distribuição ao acaso). Altamente polimerizada } \\
\text { na parede secundária (distribuição complexa). Principal } \\
\text { polissacarídeo estrutural. }\end{array}$ \\
\hline \multicolumn{4}{|l|}{ Hemiceluloses: } \\
\hline Xilogliclana & $\begin{array}{l}\text { Paredes primária e } \\
\text { secundária; } 19 \%\end{array}$ & $\begin{array}{l}\text { Glc } \beta-(1,4), \beta-(1,6) \\
\text { Xilose - } \alpha \text { terminal }\end{array}$ & $\begin{array}{l}\text { Forma pontes de hidrogênio com a celulose. Presente na } \\
\text { matriz, ao redor das fibrilas de celulose. Grau variado de } \\
\text { flexibilidade. }\end{array}$ \\
\hline Glicoronoarabinoxilana & $5 \%$ & $\begin{array}{l}\text { Xilose } \beta-(1,4) ; \text { arabinose, } \\
\text { glicoronose e } 4-O \text {-metil } \\
\text { glicoronose terminal }\end{array}$ & Principal hemicelulose em monocotiledôneas. \\
\hline $\begin{array}{l}\text { Polissacarídeos pécticos } \\
\text { Homogalacturonana }\end{array}$ & $\begin{array}{l}\text { Lamela média } \\
6 \%\end{array}$ & Galacturonose $\alpha-(1,4)$ & $\begin{array}{l}\text { Formam a matriz constituinte da lamela média. Amorfa, de } \\
\text { importante capacidade formadora de gel. }\end{array}$ \\
\hline Ramnogalacturonana I & $7 \%$ & $\begin{array}{l}\text { Galacturonose, ramnose, } \\
\text { Gal, arabinose }\end{array}$ & \\
\hline Ramnogalacturonana II & $3 \%$ & 10 tipos de radicais & \\
\hline $\begin{array}{l}\text { Arabanas, galactanas e } \\
\text { arabinogalactnas }\end{array}$ & $18 \%$ & Arabinose e Gal & \\
\hline $\begin{array}{l}\text { Glicoproteína ricas em } \\
\text { hidroxiprolina } \\
\text { Lignina }\end{array}$ & $\begin{array}{l}\text { Paredes primária e } \\
\text { secundária; } 10 \text { a } 19 \% \\
\text { Lamela média e } \\
\text { paredes secundárias }\end{array}$ & $\begin{array}{l}\text { Hidroxiprolina, serina, } \\
\text { arabinose e Gal }\end{array}$ & $\begin{array}{l}\text { Função estrutural, conferindo elasticidade. Produzida } \\
\text { também em resposta à injúria. Pode conter lectinas. } \\
\text { Unidades fenilpropanóides. } \\
\text { espessamento de paredes. Quantidades maiores em } \\
\text { tecidos diferenciados. }\end{array}$ \\
\hline Calose & Deposição localizada & & $\begin{array}{l}\text { Glicana } \beta \text { - }(1,3) \text { não-ramificada. Produzida em esposta à } \\
\text { injúria e ao estresse juntamente com lignina, proteínas e } \\
\text { fosfolipídeos. }\end{array}$ \\
\hline
\end{tabular}

${ }^{1}$ Modificado de Goodman et al. (1986) e Isaac (1992). Dados originais de polímeros de dicotiledôneas. Glc-Glicose; Gal - Galactose. Não estão incluídos $\quad \bar{\infty}$ os componentes da superfície externa, como ceras, cutícula e suberina. 


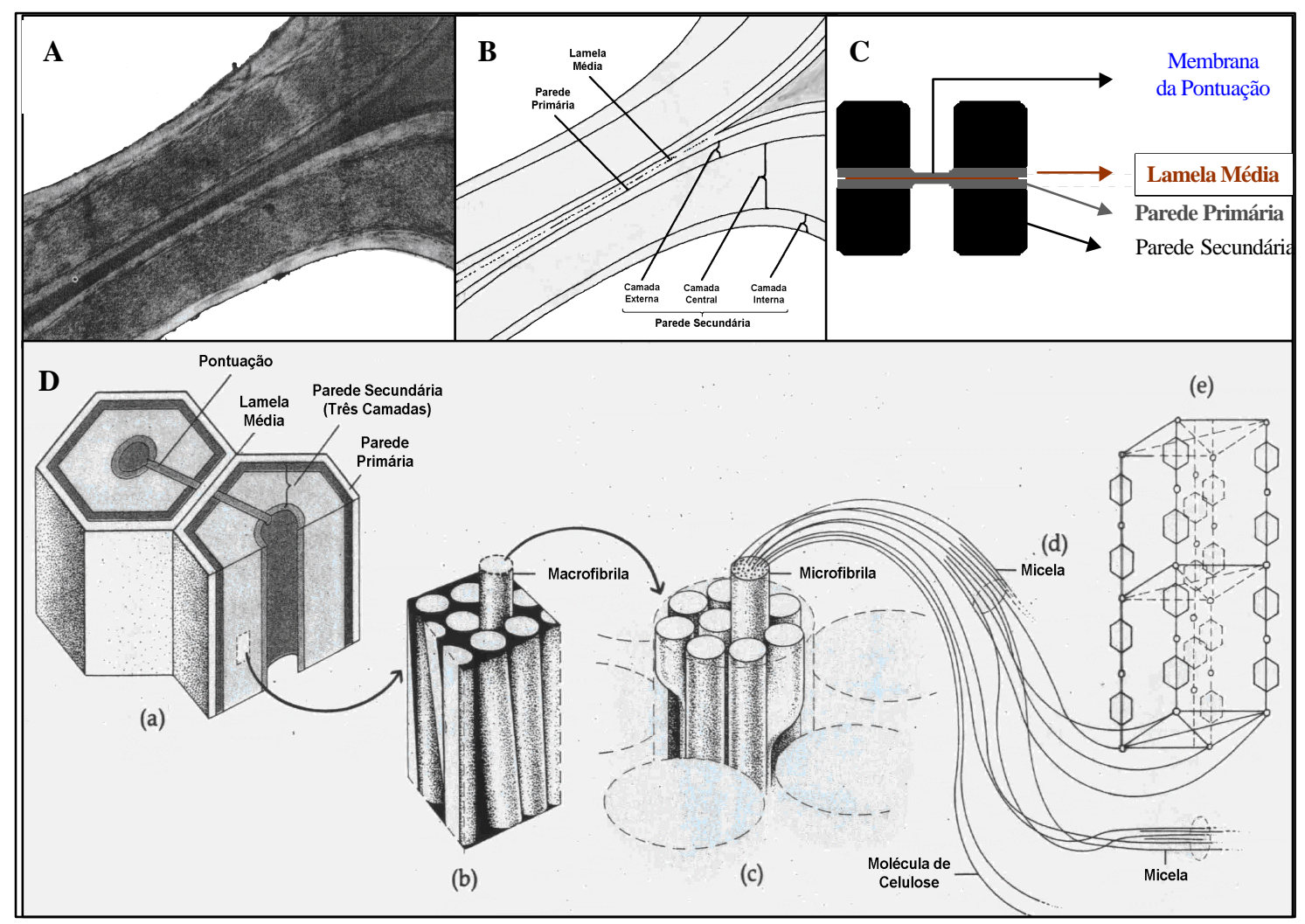

Figura 1 - Estrutura da Parede Celular Vegetal. A - Eletromicrografia da parede celular de duas células vegetais adjacentes; B - Camadas da parede celular mostrada em A, evidenciando a distinção entre lamela média, paredes primária e secundária; C Diagrama da organização de uma pontuação, ilustrando a membrana da pontuação, composta de lamela média e parede primária, numa região sem parede secundária; D - Estrutura detalhada da parede celular: a) estrutura parietal em camadas, com destaque para a pontuação; b) a celulose, o principal componente da parede celular, ocorre na forma de fibrilas de diferentes tamanhos. As fibras maiores ou macrofibrilas são formadas por estruturas menores, as microfibrilas (c); nestas microfibrilas as micelas (d) são arranjadas de modo ordenado, conferindo propriedades cristalinas à parede; e) a micela é mantida pela formação do pontes de hidrogênio entre as cadeias das moléculas de celulose (modificado de Raven et al., 1976; Raven et al., 2001). 
Purcell \& Hopkins (1996) comentam que a passagem de células de $X$. fastidiosa entre os elementos de vaso é provável. Simpson et al. (2000) também comentam que a migração radial entre vasos seria crucial para a efetiva colonização por $X$. fastidiosa, o que envolveria um sistema completo para degradar a celulose, encontrada nas paredes primárias, inclusive na membrana da pontuação. Comentam entretanto, resumidamente sobre as celulases possivelmente presentes em $X$. fastidiosa 9 a $5 \mathrm{c}$ e, mesmo nas considerações de Lambais et al. (2000) ou Dow \& Daniels (2000), somente são feitos comentários a respeito da presença de celulases. Ademais, não tecem comentários a respeito da possível presença de xilanases no genoma de $X$. fastidiosa (http://aeg.lbi.ic.unicamp.br/xf/), as quais podem ser extremamente importantes na degradação da membrana da pontuação, visto estarem as xilanas (hemiceluloses) complexadas com a celulose. Desta maneira, X. fastidiosa estaria capacitada para a degradação destes polímeros.

\subsection{Componentes das paredes celulares vegetais}

As paredes primária e secundária e a lamela média são níveis estruturais encontrados em paredes celulares vegetais. A lamela média preenche os espaços entre as paredes primárias e as células adjacentes, sendo constituída principalmente de pectina, pectato e hemicelulose. As camadas primária e secundária contêm quantidades variáveis de celuloses, hemiceluloses e pectinas. A parede secundária, embora não esteja presente em todas as células, fornece um suporte estrutural à célula, apresentando também lignina (Prade et al., 1999).

Os polímeros encontrados nas paredes celulares vegetais (Tabela 1) podem ser agrupados como celulose (glicana $\beta$-D-1,4), substâncias pécticas (galacturononanas e ramnogalacturonanas; arabinanas; galactanas e arabinogalactanas I), hemiceluloses (xilanas incluindo arabinoxilanas e [4- $O$-metil]glicoronoxilanas - glicomananas e galactoglicomanas, xiloglicanas e glicanas $\beta$-D-1,3 e $\beta$-D-1,4), outros polissacarídeos (calose, arabinogalactanas II e glicoronomananas) e glicoproteínas. As arabinogalactanas do tipo I apresentam cadeias 
lineares $\beta$-D-1,4 galactana enquanto as do tipo II apresentam cadeias internas altamente ramificadas com ligações intergalactose 1,3 e 1,6 (Aspinall, 1980).

Celulose: A celulose forma o material estrutural básico em todas as plantas superiores terrestres. A celulose é um polissacarídeo composto de unidades $\beta$-Dglicopiranosil, ligados por pontes glicosídicas $\beta-1 \rightarrow 4$, formando um polímero linear (Figura 2). Cada unidade glicose é rotacionada $180^{\circ}$ em relação a sua vizinha e o comprimento da cadeia linear pode ser de 2 a 10 mil resíduos de glicose. As regiões cristalinas da celulose são impermeáveis a água e são resistentes a degradação química e biológica.

Devido às similaridades estruturais entre celulose, xilanas e glicomananas (todos glicanas com ligação $\beta-1,4)$, pode haver a adsorção física destes polissacarídeos na superfície da celulose. Uma relação estrutural mais próxima existe entre celulose e xiloglicanas que ocorrem como componentes nas paredes primárias em dicotiledôneas. Além de celulose, podem ser encontrados outros polímeros $\beta$-D-glicana não celulósicos, como a calose (Dglicana $\beta$-1,3) e D-glicanas com ligações $\beta$-1,3 e $\beta$-1,4.

Hemicelulose: As hemiceluloses são compostas de uma série de heteropolissacarídeos incluindo glicanas, mananas, arabinanas e xilanas. As xilanas são os polissacarídeos mais comuns entre as hemiceluloses, compostos de unidades D-xilopiranosil com ligações $\beta$ - $(1,4)$ e são componentes principalmente das paredes celulares secundárias, apresentando baixo grau de ramificação. As xilanas de dicotiledôneas contêm aproximadamente 10 \% de unidades ácido D-glicorônico 4- $O$-metila e menores quantidades de unidades L-arabinose (Aspinall, 1980).

A manana é uma hemicelulose presente principalmente em madeiras leves, podendo apresentar estrutura linear com unidades de manose através de ligações $\beta$-1,4 ou estrutura heteropolimérica, com a manose ligada a unidades de glicose por ligações $\beta-1,4$ (glicomanana). As unidades manose são freqüentemente substituídas com galactose e grupos $O$-acetila. 


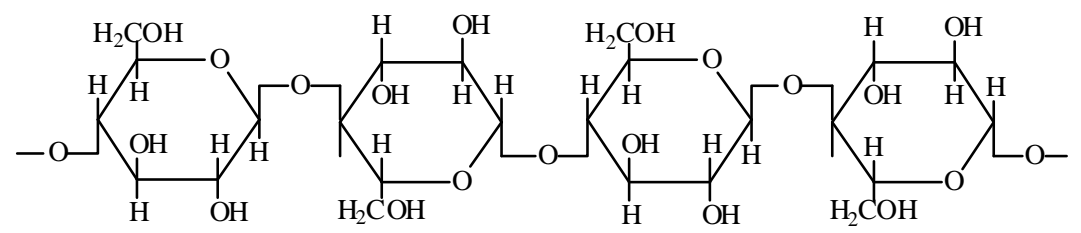

CELULOSE (glicana beta-D-1,4)

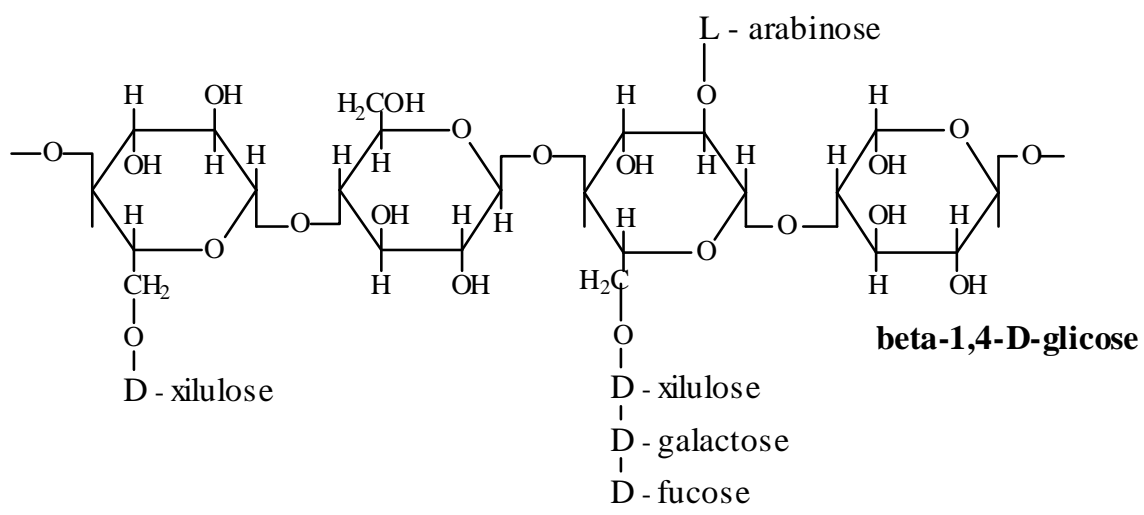

HEMICELULOSE (xiloglicana)

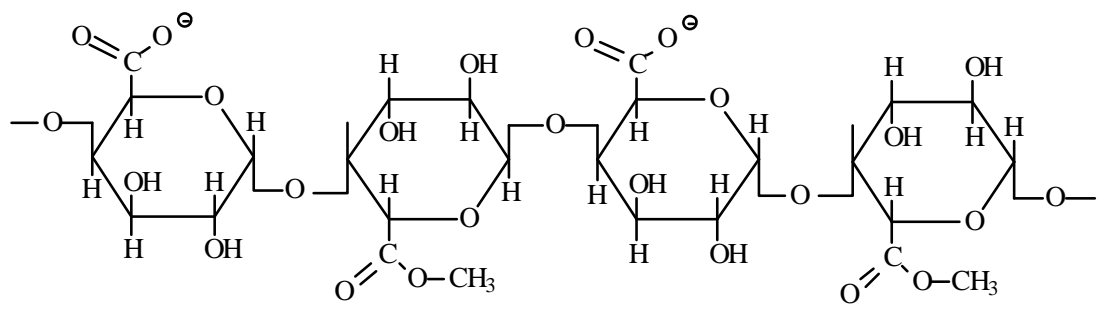

PECTINA (ácido alfa-1,4-D-poligalacturônico)

Figura 2 - Principais constituintes da parede celular vegetal. A celulose (polímero de $\beta$-glicose), juntamente com a xilana (hemicelulose formada de $\beta$-xilosídeo) e outros polímeros, formam as paredes primárias. Pectina (metilada) e pectato (sem radicais metila) são os principais

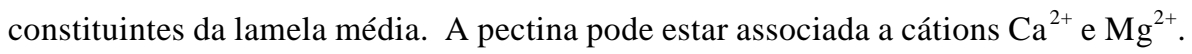


Substâncias pécticas: este termo é utilizado de uma maneira geral para referirse a um grupo complexo de polissacarídeos das paredes celulares primárias e regiões intercelulares das plantas superiores. O termo substâncias pécticas abrange o éster metílico, a pectina; o ácido péctico desesterificado e seus sais, os pectatos; além de certos polissacarídeos neutros sem a estrutura principal galacturonana, que são freqüentemente encontrados em associação com a pectina. A característica dominante da pectina, o principal constituinte das substâncias pécticas, é uma cadeia linear de unidades de ácido D-galacturônico no qual proporções variáveis dos grupos ácidos (40 a 60 \%) estão presentes como ésteres metílicos (Aspinall, 1980; Heldt \& Heldt, 1997; Prade et al., 1999).

Proteínas: A matriz extracelular vegetal contém diversas classes de proteínas e glicoproteínas, as quais podem ser covalentemente ligadas na parede celular ou podem ser solúveis em grau variado. Uma classe é constituída pelas glicoproteínas ricas em hidroxiprolina, na qual a extensina é um exemplo. A extensina é onipresente nas paredes celulares como um componente estrutural da parede celular primária (Aspinall, 1980). A expressão das glicoproteínas ricas em hidroxiprolina (PRHP) e das proteínas ricas em prolina (PRP) acompanha a diferenciação do tecido vegetal, podendo apresentar funções como determinar a rigidez da parede e a conseqüente resistência do tecido à invasão dos patógenos (Dow et al., 1998). A imobilização do patógeno através de ligação a PRHPs ou PRPs e o fortalecimento da matriz extracelular pelo aumento da deposição de PRHPs e intercruzamento das PRHPs e PRPs, são os possíveis mecanismos pelos quais estas glicoproteínas contribuiriam para aumentar a resistência da parede

\subsubsection{Mecanismos de patogenicidade / virulência}

Em muitos casos, o estudo dos mecanismos de patogenicidade encontra suporte em modelos de interação patógeno-animal, o que não invalida a informação, pelo contrário, fornece uma perspectiva filogenética do evento em questão. 
Quase todos os fatores de virulência estão localizados na superfície bacteriana ou são secretados. Muitos fatores necessários para o transporte de fatores de virulência, os fatores acessórios, são comuns e homólogos. "Fatores extracelulares de virulência" são, em princípio, quaisquer moléculas presentes na superfície bacteriana ou translocadas para o ambiente extracelular. Livremente definidos desta maneira, estes fatores incluem enzimas degradadoras das paredes celulares, toxinas, DNA, hormônios, sideróforos e moléculas sinalizadoras. Além destas, estruturas ancoradoras na superfície celular, tais como flagelos, pili, lipopolissacarídeos, polissacarídeos extracelulares (PSE) e proteínas da membrana externa podem auxiliar na sobrevivência da bactéria dentro, ou na invasão da planta hospedeira (Salmond, 1994; Finlay \& Falkow, 1997). Nas bactéria fitopatogênicas, além dos fatores de patogenicidade acima citados, são estudados as enzimas, proteínas dos sistemas Hrp e Avr, bem como a capacidade de induzir a formação de tumores.

Há uma notável similaridade entre os sistemas enzimático e secretório entre Xanthomonas campestris e X. fastidiosa. Provavelmente esta similaridade é devido à proximidade evolutiva entre ambas. A mesma organização genética do sistema de secreção de tipo II que é encontrada em $X$. c. pv. campestris é observada em X. fastidiosa (Dow \& Daniels, 2000). Maior suporte a este compartilhamento advém da alta similaridade entre proteínas que são secretadas via sistema de secreção do tipo II (sistema xps em $X$. c. pv. campestris). Outra similaridade observada é em relação ao operon gum de $X$. c. pv. campestris, o qual codifica os genes necessários para a produção da goma xantana (genes Xf2360 a Xf-2370). Entretanto, da mesma maneira que no sistema xps, existem diferenças entre os dois operons (Silva et al., 2001), o que pode resultar em produção de uma goma com características distintas da goma xantana (Katzen et al., 1998), refletindo talvez a diferença na colonização ou no hospedeiro entre as bactérias, ou pode somente refletir distinções metabólicas e fisiológicas entre ambas.

As exoenzimas, principalmente as que são estudadas devido ao seu envolvimento na patogênese, são secretadas através do sistema de secreção do tipo II. Em $X$. 
fastidiosa são encontrados homólogos de seqüência aos genes xps de Xanthomonas (genes $\mathrm{Xf}-1517$ a Xf-1527). Os genes $\operatorname{rpf}$ ("regulation of pathogenicity factors") que controlam, entre outras funções, a expressão de exoenzimas em Xanthomonas também foram identificados, por homologia de sequiência em X. fastidiosa, nas genes Xf-1108 a Xf-1115, Xf-287 (rpfB) e Xf-290 (rpfA). Em X. c. pv. campestris, os genes rfp são encontrados em cluster, enquanto em $X$. fastidiosa estão localizados parcialmente em cluster. Não foram encontrados homólogos de seqüência a rpfD e rpfI.

Em muitos casos, a produção de fatores de patogenicidade ou virulência é controlada de maneira dependente da densidade celular. Esta regulação por um "sensor quorum" foi descrita inicialmente em Vibrio fisheri, um organismo em que a bioluminescência é controlada pelo par LuxI/LuxR (Pierson et al., 1998) e sua regulação através da síntese de homoserina lactona acilada foi demonstrada em A. tumefaciens, Erwinia carotovora, Pseudomonas aeruginosa, P. aureofasciens, Escherichia coli e Ralstonia leguminosarum, onde está presente o sistema gênico luxR/luxI. O primeiro é responsável pela regulação do sensor quorum, enquanto o segundo sintetiza a homoserina lactona acilada. Somente foi encontrado um componente do sistema regulador por "sensor quorum" em X. fastidiosa, LuxR, uma proteína que tem a assinatura para interação com homoserina lactona acilada (Lambais et al., 2000). Entretanto, seu par funcional luxI, ou não existe ou não apresenta similaridade com os genes luxI atualmente conhecidos.

Entretanto, em X. c. pv. campestris e possivelmente nas Xanthomonas spp., o sistema análogo ao "sensor quorum" deve ser um sistema de regulação através de fatores sinais difusíveis (DSF), derivados de ácidos graxos. A produção e/ou percepção é controlado pelos genes rpf, funcionando como um sistema de sinalização célula a célula. Dow \& Daniels (2000), sugerem existir evidências circunstanciais para a ocorrência deste sistema DSF em $X$. fastidiosa, nos moldes de X. c. pv. campestris. Como X. fastidiosa apresenta outras similaridades com Xanthomonas, nada mais lógico do que encontrar os mesmos circuitos regulatórios e enzimáticos. Mutantes $r p f^{-}$de $X$. c.pv. campestris secretam níveis menores de protease, poligalacturonato Iase, endoglicanase e amilase, assim como baixos níveis de PSE, 
quando comparados ao tipo selvagem (Wilson et al., 1998). RpfA é a aconitase mais abundante em $X$. c. pv. campestris, participando da homeostase do ferro e regulação da expressão gênica de PSE e das exoenzimas protease-serino e de uma endoglicanase (Wilson et al., 1998). Os genes $r p f B$ e $r p f F$ participam da síntese do fator difusível, enquanto os outros genes do operon ( $r p f G, r p f H$ e $r p f C$ ) participam da percepção de sinais (Barber et al., 1997; Dow et al., 2000).

\subsubsection{Enzimas degradadoras da parede celular vegetal (EDPCV)}

As bactérias fitopatogênicas podem viver nos espaços intercelulares ou no interior das células (como os elementos de vaso) e dependendo do modo de colonização, podem utilizar enzimas para degradar a parede celular vegetal. Estas enzimas, coletivamente denominadas de enzimas degradadoras da parede celular vegetal (EDPCV), compreendem pectinases, celulases, xilanases e proteases. As EDPCV podem apresentar ação tanto sinérgica como seqüencial na degradação dos substratos.

A parede celular das plantas superiores é constituída de até $90 \%$ de carboidratos e $10 \%$ de proteínas. Como descrito, as paredes celulares apresentam celulose, hemiceluloses, substâncias pécticas, proteínas e lignina. Entretanto, a proporção e a distribuição destes componentes é variável de acordo com células de diferentes tecidos, idades, condições fenológico-ambientais e mecanismos de defesa da planta hospedeira.

As celulases CelV1 e CelS de E. carotovora subsp. carotovora são coordenadamente induzidas de uma maneira dependente da fase de crescimento e são reprimidas por catabólitos. A expressão de $c e l V 1$, mas não de $c e l S$ foi estimulada por extratos vegetais. Mutantes $\mathrm{celVI}{ }^{-}$exibiram redução na virulência, sugerindo que este gene possa aumentar a habilidade da bactéria em macerar o tecido. Os autores demonstraram que a atividade celulolítica em E. c. subsp. carotovora é necessária para o progresso normal dos sintomas da doença em fumo, sendo assim um determinante de virulência (Mäe et al., 1995). Da mesma forma que a endoglicanase é importante na virulência em E. carotovora subsp. carotovora (Mäe et al., 1995), sua importância já foi considerada em Ralstonia 
solanacearum (Roberts et al., 1988). Entretanto, a endoglicanase EngXCA de X c. pv. campestris exerce uma pequena função nos primeiros estágios da patogenicidade em nabo e rabanete (Gough et al., 1988; Gough et al., 1990). Boccara et al. (1994) mostraram que em E. chrysanthemi as celulases (celZ e celY) não são essenciais para o desenvolvimento dos sintomas em folhas de Saintpaulia ionantha, embora com a linhagem celY ${ }^{-}$os sintomas demorem mais a surgirem. A parede celular é altamente degradada em cultivares de mandioca suscetíveis à infecção por $X$. c. pv. manihotis, o que ficou evidente através de estudos citoquímicos (Boher et al., 1997).

Por outro lado, em bactérias fitopatogênicas Gram-positivas como $C$. michiganensis ssp. michiganensis (Jahr et al., 1999; Meletzus et al., 1993) e C. m. ssp. sepedonicus (Laine et al., 2000), as endoglicanases apresentam uma função marcante no desenvolvimento dos sintomas, como evidenciado na murcha do tomateiro. Especula-se que as celulases podem ser responsáveis pela degradação da parede dos vasos do xilema, interferindo no transporte de seiva e permitindo que ocorra a colonização lateral no hospedeiro pela bactéria. Laine et al. (2000) relatam a caracterização do gene de uma celulase essencial para a completa virulência de $C$. michiganensis ssp. sepedonicus. Este gene localiza-se em um plasmídio e apresenta $35 \%$ de identidade no domínio catalítico e $28 \%$ de identidade no domínio 3 com o gene Xf - 810 de X. fastidiosa (menor similaridade com o gene Xf - 818). Este domínio 3 apresenta similaridade com um domínio expansina, o que pode estar relacionado à capacidade de clivar a celulose através do acesso facilitado ao substrato insolúvel.

A habilidade das liases do pectato em macerar o tecido vegetal é variável. As isoenzimas básicas, PelD e PelE de E. chrysanthemi, maceram efetivamente o tecido vegetal, causando perda de eletrólitos e morte celular (Hugouvieux-Cotte-Pattat et al., 1996). Os genes pel, considerados isoladamente, não são essenciais para a maceração. Observa-se que a contribuição de cada isoenzima para a patogenicidade/virulência varia de acordo com a planta infectada. 
Além das celulases e pectinases, relatos da importância de proteases na patogênese bacteriana são observados. Dow et al. (1998) caracterizaram uma metaloprotease zinco que é ativa na degradação de proteínas ricas em hidroxiprolina (PRHPs) de Brassica campestris e de proteínas ricas em prolina (PRPs) de outros vegetais, a partir de X. c. pv. campestris.

\subsection{Celulases}

As enzimas conhecidas como celulases hidrolisam a ligação glicosídica entre dois ou mais carboidratos ou entre um carboidrato e uma porção não carboidrato. A classificação das hidrolases $O$-glicosídicas (EC 3.2.1.-) conforme a nomenclatura enzimática IUB - MB é feita com base na sua especificidade ao substrato e ocasionalmente no seu mecanismo molecular. De acordo com esta nomenclatura, o 3 refere-se a hidrolases; 3.2 glicosilases e 3.2.1. glicosidase, isto é, enzimas que hidrolisam compostos $o$-glicosil ou $s$ glicosil. Uma classificação com base nas similaridades da sequiência de aminoácidos do domínio catalítico foi proposta (Henrissat, 1991; Henrissat \& Bairoch, 1993) e atualmente as hidrolases glicosídicas são agrupadas em 87 famílias.

A hidrólise enzimática das pontes glicosídicas ocorre através de catálise ácida geral, onde são necessários dois aminoácidos críticos: um doador de próton e um nucleófilo/base. A catálise ácida é usualmente promovida pelos resíduos aspartato ou glutamato, ou ambos. Resíduos encontrados em sítios ativos são usualmente altamente conservados durante a evolução (Gilkes et al., 1991). Nesta catálise, ocorre uma reação de remoção simples ou dupla, resultando em inversão ou retenção, respectivamente, da configuração anomérica do átomo de carbono do glicosídio hidrolisado (Davies et al., 1995).

A conversão enzimática da celulose em glicose é uma árdua tarefa, devido à natureza física do substrato. Na sua forma nativa, a celulose é composta principalmente de fibras cristalinas insolúveis, nas quais as pontes de hidrogênio mantêm as móleculas unidas. Adicionalmente, as fibras são embebidas em uma matriz de hemicelulose e lignina, a qual reduz a acessibilidade às enzimas celulolíticas (Béguin, 1990). A conversão microbiana da celulose e 
xilana em produtos solúveis necessita diversos tipos de enzimas: endoglicanases (EC 3.2.1.4), celobiohidrolases (EC 3.2.1.91), xilanases (EC 3.2.1.8) (Gilkes et al., 1991).

Algumas celulases hidrolisam tanto a celulose como a xilana e algumas xilanases ligam-se à celulose (Gilkes et al., 1991). Embora sejam quimicamente similares, a celulose e a xilana adotam conformações diferentes (Figura 2). A xilana é mais flexível e apresenta substituições de arabinose, ácido glicorônico ou ácido metilglicorônico.

As celulases são algumas vezes descritas como um grupo complexo de enzimas com ação sinérgica. Este grupo reúne :

Endoglicanases (EC 3.2.1.4) [EG] são enzimas que catalisam a hidrólise interna de ligações $\beta$-1,4-D-glicosídicas da celulose. Podem hidrolisar também ligações $\beta$-1,4 em D-glicanas que contenham lgações $\beta$-1,3. As endoglicanases são também conhecidas como celulases, endo $\beta-1,4$ glicanases e carboximetil celulases. Seu substrato natural é a celulose e xiloglicana, apresentando especificidade variável sobre carboximetil celulose (CMC), Avicel (celulose cristalina), $\beta$-glicana e xilana.

Celulose beta-1,4-celobiosidase (EC 3.2.1.91), [CBH] conhecida também como exoglicanase, celobiohidrolase, $\beta$-1,4-celobiohidrolase ou Avicelase. Catalisam a hidrólise de ligações $\beta$-1,4-D-glicosídicas na celulose e celotetraose, liberando celobiose das extremidades não redutoras das cadeias.

Beta-glicosidase (EC 3.2.1.21), conhecida como gentobiase, celobiase e amigdalase. Catalisa a hidrólise de resíduos $\beta$-D-glicose terminais não redutores, liberando $\beta$ D-glicose. Apresenta ampla especificidade por $\beta$-D-glicosídeos, podendo hidrolisar também $\beta$-D-galactosídeos, $\alpha$-L-arabinosídeos, $\beta$-D-xilosídeos e $\beta$-D-fucosídeos.

Beta-1,3(4)-endo-glicanase (EC 3.2.1.6), conhecida também como $\beta$-1,4endo-glicanase, $\beta$-1,3-endoglicanase ou laminarinase. Esta enzima catalisa a hidrólise interna de ligações $\beta-1,3$ ou $\beta-1,4$ em da glicose Dglicanas. Tem como substrato a laminarina, lichenina e D-glicana. É uma enzima diferente de glicana $\beta$-1,3-endo-D-glicosidase (EC 3.2.1.39), embora ambas hidrolisem o substrato laminarina. 
Outra enzima que age sobre a celulose é a polisulfatase de celulose (EC 3.1.6.7). Hidrolisa os grupos sulfatos -2 e -3 dos polissulfatos da celulose, não tendo sido encontrada em microrganismos. Bactérias como Termothoga neapolitanae e Cellulomonas uda possuem a enzima fosforilase da celobiose, a qual catalisa a formação de D-glicose e Dglicose- $\alpha$-1-fosfato a partir de celobiose e fosfato (ortofosfato), a qual é então absorvida e metabolisada. As endoglicanases (EC 3.2.1.4) e as celobiohidrolases (EC 3.2.1.91) degradam celodextrinas solúveis e celulose amorfa, enquanto somente as celobiohidrolases, com notáveis exceções, degradam a celulose cristalina eficientemente (Schülein, 2000).

Algumas hidrolases glicosídicas são enzimas multifuncionais que contêm domínios catalíticos que pertencem a diferentes famílias. As celulases e xilanases apresentam múltiplos domínios, podendo possuir domínios catalíticos, domínio ligador de celulose e seqüências ligadoras (Gilkes et al., 1991).

As sequiências dos domínios ligadores parecem ser menos variáveis do que a dos domínios com atividade catalítica, porque estes últimos conferem diferenças sutis na especificidade e no mecanismo, dentro deste grupo de enzimas (Gilkes et al., 1991). Embora os domínios ligadores de celulose (DLC - "Cellulose binding domain”) não sejam essenciais para atividade catalítica, eles modulam a atividade específica das enzimas em substratos celulolíticos solúveis e insolúveis. Os DLC são identificados como módulos ligadores de carboidrato (MLC - "carbohydrate-binding module") que são definidos como uma sequiência de aminoácidos contígua, dentro de uma enzima ativa sobre carboidratos. Sua estrutura terciária independe da estrutura do domínio catalítico, e sua classificação é feita em 13 famílias (Tomme et al., 1995).

Enzimas com sequiências similares (domínios catalíticos) apresentam diferentes especificidades (exo ou endohidrólise), o que sugere que esta atividade seja consequiência de detalhes na estrutura tridimensional da proteína. A endoglicanase CelB de Caldocellum saccharolyticum tem um domínio exoglicanase N-terminal e outro domínio endoglicanase, este C-terminal, os quais pertencem a diferentes famílias, sendo uma enzima bifuncional (Gilkes et al., 1991). 
As exoenzimas produzidas pelas bactérias usualmente contêm um peptídio sinal (para transporte através da membrana). A endoglicanase EngXCA de X. c. pv. campestris possui um peptídio sinal de 25 aminoácidos na extremidade N-terminal (Gough et al., 1990), ao passo que a endoglicanase $\mathrm{S}(\mathrm{CelS})$ de Erwinia carotovora subsp. carotovora apresenta um peptídio sinal de 32 aminoácido, o qual é clivado da pré-CelS (Saarilhati et al., 1990).

Todos organismos que degradam a celulose cristalina secretam sistemas mais ou menos complexos de celulases. Tais sistemas são compostos de uma variedade de enzimas com especificidade e modo de ação distintos, as quais agem em sinergia hidrolisando a celulose (Béguin, 1990). Diversos genes que codificam celulases (endoglicanases) foram clonados e as enzimas caracterizadas a partir de bactérias fitopatogênicas (Tabela 2), como em Erwinia chrysanthemi, E. carotovora, Xanthomonas campestris e Clavibacter michiganensis. O número de genes conhecidos está aumentando consideravelmente, devido aos programas de seqüenciamento, com X. fastidiosa, Xanthomonas e Leifsonia xyli ssp. xyli, este último ainda não publicado (ONSA/FAPESP).

As enzimas endoglicanase e celobiohidrolase mostram diferentes tipos de sinergia na hidrólise da celulose cristalina (Henrissat et al., 1985). Poucas exoglicanases foram caracterizadas, mas a ação sinérgica entre EG e CBH na degradação da celulose cristalina foi demonstrada (Creuzet et al., 1983). Em E. chrysanthemi, há sinergia entre as endoglicanases CelY e CelZ. Zhou \& Ingram (2000) criaram um modelo com base em dados experimentais onde a ação de CelY, embora menos ativa, potencializa a atividade catalítica da CelZ sobre a celulose amorfa. Estas enzimas apresentam requerimentos diferentes, mas complementares para o tamanho do substrato (Zhou \& Ingram, 2000).

Dois tipos de mecanismos controlam a síntese e secreção de celulases. $\mathrm{Na}$ maioria dos organismos, a produção de celulase é reprimida na presença de altas concentrações de fonte de carbono prontamente metabolisáveis. Adicionalmente, em diversos sistemas, a síntese de celulase é regulada por celobiose ou soforose, que são geradas a partir da degradação da celulose por pequenas quantidades de celulases constitutiva (Béguin, 1990). A síntese de celulases parece ser regulada ao nível 
Tabela 2. Genes de celulases (endoglicanases - EG e celobiohidrolases - CBH) em bactérias fitopatogênicas ${ }^{1}$.

\begin{tabular}{|c|c|c|c|}
\hline Organismo & Enzima & Gene & Referência \\
\hline $\begin{array}{l}\text { Agrobacterium } \\
\text { tumefaciens } \\
\text { Clavibacter }\end{array}$ & $\mathrm{EG}$ & & Goodner et al., 2001. \\
\hline $\begin{array}{l}\text { michiganenensis ssp. } \\
\text { michiganensis }\end{array}$ & EG & celA & $\begin{array}{l}\text { Meletzus et al., } 1993 . \\
\text { Jahr et al., } 2000 .\end{array}$ \\
\hline $\begin{array}{l}\text { Clavibacter m. ssp. } \\
\text { sepedonicus }\end{array}$ & EG & celA & Laine et al., 2000. \\
\hline Erwinia carotovora & EG & $\begin{array}{l}\text { celA } \\
\text { cels } \\
\text { celV }\end{array}$ & $\begin{array}{l}\text { Park et al., } 1998 . \\
\text { Saarilahti et al., } 1990 . \\
\text { Cooper \& Salmond, } 1993 .\end{array}$ \\
\hline E. chrysanthemi & EG & $\begin{array}{l}\text { cel5 } \\
\text { celY }\end{array}$ & $\begin{array}{l}\text { Guiseppi et al., } 1988 . \\
\text { Guiseppi et al., } 1991 .\end{array}$ \\
\hline Ralstonia solanacearum & EG & $E g l$ & $\begin{array}{l}\text { Roberts et al., 1988; } \\
\text { Salanoubat et al., } 2002 .\end{array}$ \\
\hline $\begin{array}{l}\text { Xanthomonas } \\
\text { albilineans }\end{array}$ & EG & $E g x A$ & Vancov \& Dunn, 1994 \\
\hline X. axonopodis pv. citri & EG & $\begin{array}{l}\text { Xca } 0028 \text { / Xca } 0029 \\
\text { Xca } 0030 \text { / Xca } 0346 \\
\text { Xca } 0612 \text { / Xca } 1770 \\
\text { Xca } 2522 \text { / Xca } 3506 \\
\text { Xca } 3507 \text { / Xca } 3516\end{array}$ & $\begin{array}{l}\text { Silva et al., 2002; } \\
\text { http://watson.fapesp.br/onsa } \\
\text { /Genoma3.htm }\end{array}$ \\
\hline $\begin{array}{l}X . \text { campestris pv. } \\
\text { campestris }\end{array}$ & $\mathrm{CBH}$ & $\begin{array}{l}\text { Xcc } 0026 \text { / Xcc } 0027 \\
\text { Xcc } 0028 \text { / Xcc } 1752 \\
\text { Xcc } 2387 \text { / Xcc } 3380 \\
\text { Xcc } 3381 \text { / Xcc } 3521 \\
\text { Xcc } 3535 \\
\text { Xcc } 3160 \text { / Xcc } 3534\end{array}$ & $\begin{array}{l}\text { Silva et al., 2002; } \\
\text { http://watson.fapesp.br/onsa } \\
\text { /Genoma3.htm }\end{array}$ \\
\hline$X . c$. pv. campestris & EG & engXCA & $\begin{array}{l}\text { Gough et al., } 1990 . \\
\text { Gough et al., } 1988 .\end{array}$ \\
\hline $\begin{array}{l}\text { Xylella fastidiosa } 9 \mathrm{a} 5 \mathrm{c}- \\
\text { citros }\end{array}$ & $\begin{array}{l}\text { EG } \\
\text { EG } \\
\text { EG } \\
\text { CBH }\end{array}$ & $\begin{array}{l}X f-810 \\
X f-818 \\
X f-2708 \\
X f-1267\end{array}$ & $\begin{array}{l}\text { Simpson et al., 2000; } \\
\text { http://aeg.lbi.ic.unicamp.br/x } \\
\text { f/ }\end{array}$ \\
\hline
\end{tabular}

1 Os genes de $X$. axonopodis pv. citri e $X$. c. pv. campestris (Silva et al., 2002) foram identificados através de comparação de sequiência, assim como os de X. fastidiosa 9a5c (Simpson et al., 2000). X. fastidiosa videira, X. fastidiosa amendoeira e X. fastidiosa espirradeira, apresentam sequiências similares às celulases de $X$. fastidiosa 9a5c (Bhattacharyya et al., 2002; http://aeg.lbi.ic.unicamp.br/aeg/aeg.html). 
transcricional e os transcritos são monocistrônicos. Os genes das celulase, CelA e CelB, de Thermotoga neopolitana são induzíveis por celobiose e reprimidos por glicose. Os principais produtos finais da hidrólise da celulose, glicose e celobiose, competitivamente inibem estas enzimas (Bok et al., 1998). A celobiohidrolase CelK de C. thermocellum é inibida pela celobiose (Kataeva et al., 1999).

A despeito da capacidade hidrolítica das celulases, algumas são capazes de efetuar transglicosilação. A transglicosilação é a formação de trímeros e tetrâmeros a partir de celobiose. Por exemplo, Kono et al. (1999) relatam a capacidade transglicosídica de uma celulase de Trichoderma viride, enquanto Bok et al. (1998) descrevem uma celulase (CelB) de Thermotoga neopolitana com alta capacidade para efetuar transglicosilação.

\subsection{Hemicelulases}

Devido à sua complexa estrutura, a degradação completa da xilana requer a ação conjunta de diversas enzimas hidrolíticas. As endoxilanases $\beta$-1,4 (EC 3.2.1.8) clivam a estrutura principal da xilana, e as $\beta$-xilosidases (EC 3.2.1.37) clivam monômeros de xilose das extremidades não redutoras de oligômeros de xilose. A remoção dos grupos laterais é catalisada por $\alpha$-glicuronidases (EC 3.2.1.134), $\alpha$-L-arabinosidases (EC 3.2.1.155) e acetilesterases (EC 3.1.1.72). No caso da manana, a parte central da molécula é hidrolisada por $\beta-1,4$ endomananases, produzindo manobiose e oligossacarídeos, os quais são clivados por $\beta$-manosidases para liberar manose (Braithwaite et al., 1995).

Braun \& Rodrigues (1993) destacam que uma parede celular típica de dicotiledônea apresenta $20 \%$ de xiloglicana e $5 \%$ de xilana, enquanto uma parede de gramínea pode apresentar de 30 a $40 \%$ de arabinoxilana e somente traços de xiloglicana. $E$. chrysanthemi isolada de milho produz duas xilanases (Braun \& Rodrigues, 1993; Keen et al., 1996; Vroemen et al., 1995). Os genes que codificam estas xilanases, bgxA e xynA, não são essenciais para que a bactéria cause sintomas em folhas de milho (Vroemen et al., 1995; Keen et al., 1996). Enzimas que hidrolisam a manana e xilana (hemicelulases) são amplamente 
negligenciadas em bactérias fitopatogênicas, embora estes polímeros sejam abundantes componentes da hemicelulose, especialmente em madeiras leves.

\subsection{Pectinases}

As substâncias pécticas são despolimerizadas ou modificadas por 3 classes de enzimas: esterases (esterase da pectina e pectina acetil esterase), hidrolases (poligalacturonases) e eliminases ou liases (liase de pectina, liase de pectato), as quais podem atuar em sinergia. As liases clivam ligações glicosídicas internas através de eliminação beta, produzindo oligômeros ou monômeros com resíduos insaturados-4,5 na extremidade não redutora (Figura 3). As galacturonases causam a hidrólise das ligações galacturonosídicas e provavelmente clivam as ligações oxigênio-glicosídeo. As poligalacturonases diferem em seu modo de ação, podendo ocasionar hidrólise ao acaso (endo) ou atuando somente nas extremidades das cadeias com liberação gradual de galacturonobiose (exo). A esterase e a acetil esterase da pectina, facilitam a degradação da pectina pela liase do pectato, pela geração de poligalacturonato através da desmetilação (hidrólise dos grupos ésteres) e desacetilação da pectina, respectivamente (Bekri et al., 1999).

A degradação enzimática completa das substâncias pécticas pelas pectinases resulta primariamente em ácido galacturônico e ramnose, com a produção de menores quantidades de galactose, arabinose, metanol, acetato e traços de diversos outros açúcares (xilose, fucose e apiose), os quais são assimilados e metabolisados pelos microrganismos.

Em Pseudomonas viridiflava (Liao et al., 1988) um liase de pectato extracelular de $42 \mathrm{kDa}$ é necessária para maceração do tecido vegetal, pois um mutante para este gene não apresenta esta capacidade macerativa. A habilidade de linhagens de 


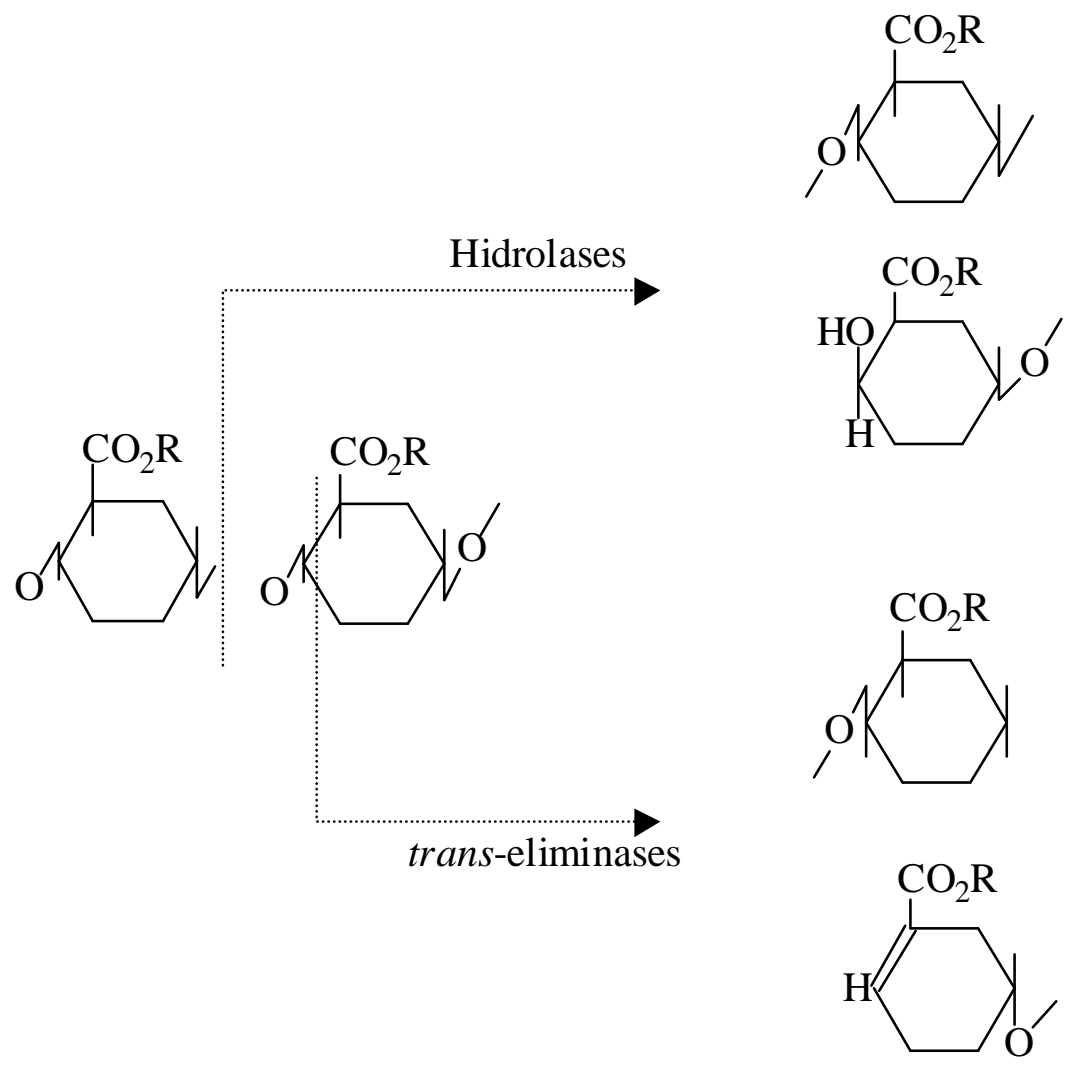

Figura 3 - Enzimas pécticas. Diferenças catalíticas entre as hidrolases (por exemplo uma poligalacturonase) e liases (trans-eliminases; por exemplo uma liase de pectato) na clivagem do polímero péctico. Observar a formação de ligação dupla após a ação da liase.

$X$. campestris em produzir liase de pectato está intimamente associada com sua habilidade em induzir podridão em tubérculos de batata e em pimentões (Liao et al., 1996).

\subsection{Proteases}

Proteases na maioria dos trabalhos são caracterizadas em ensaios com $\beta$ caseína. Entretanto, o envolvimento na patogênese não é comprovado, sendo provavelmente importantes para a utilização de produtos protéicos liberados da célula vegetal após sua lise. Devemos considerar, entretanto, que a caracterização da enzima quanto ao substrato 
degradado, ou seu mutante defectivo, requer uma correta relação com a disponibilidade e presença do substrato na planta e sua importância no surgimento dos sintomas. Dow et al. (1998) caracterizaram uma metaloprotease zinco eficaz na degradação da extensina de tomate e de batata, entretanto a mesma não foi ativa contra lectinas de solanáceas. Esta metaloprotease é diferente das três proteases previamente caracterizadas através do substrato $\beta$-caseína, pois não o hidrolisa. Mutantes para a produção de proteases (ativas em caseína) de $X$. c. pv. campestris não tiveram sua virulência reduzida (Tang et al., 1987). Assim, é lógico supor uma maior importância na patogênese da bactéria, da protease que degrada PRHPs do que as proteases que degradam somente caseína.

Uma protease extracelular de E. c. subsp. carotovora, ativa em gelatina e azocaseína, pode degradar proteínas ricas em hidroxiprolina de batata e tomate (Willis et al., 1987). Heilbronn et al. (1995) purificaram uma metaloprotease extracelular de outro isolado de E. c. subsp. carotovora, ativa contra leite desnatado e azocaseína e capaz de degradar lentamente a lectina de batata. O gene $\operatorname{prt} W$ é fortemente induzido na presença de extrato vegetais e o mutante $p r t W$ apresenta virulência reduzida, sugerindo que PrtW aumenta a habilidade da linhagem SCC3193 em macerar o tecido vegetal (Marits et al., 1999).

A linhagem P de X. fastidiosa PD produz no mínimo duas proteases (P1 e P2) de 54 e 50 kDa, ativas em gelatina e caseína (Fry et al., 1994). Dow et al. (1993) não observaram relação determinativa entre o padrão da expressão dos genes da protease (zinco metaloprotease) e o modo (vascular ou mesofílico) de patogênese.

\subsection{Perspectivas em Fitobacteriologia}

O momento atual é um dos mais férteis em relação à quantidade de informação disponível no tocante aos genomas completos das bactérias fitopatogênicas, como $X$. fastidiosa CVC - 9a5c (Simpson et al., 2000), Agrobacterium tumefaciens C58 (Goodner et al., 2001), Ralstonia solanacearum GMI1000 (Salanoubat et al., 2002), X. axonopodis pv. citri 306, Xanthomonas campestris pv. campestris ATCC 33913 (Silva et al., 2002), X. 
fastidiosa PD (http://aeg.lbi.ic.unicamp.br/ - ONSA/FAPESP), X. fastidiosa "almond" linhagem Dixon e X. fastidiosa "oleander" - linhagem Ann1 (Bhattacharyya et al., 2002) e Leifsonia xyli subsp. xyli (http://aeg.lbi.ic.unicamp.br/ - ONSA/FAPESP). Obviamente a informação gerada pelo sequienciamento completo somente é possível devido à informação gerada a partir da análise de fragmentos gênicos efetuada nos anos anteriores. Entretanto, a disponibilidade desta informação abre caminho para a compreensão da função e estrutura de novos genes, suas proteínas e todas rotas metabólicas derivadas da ação das enzimas.

A caracterização do proteoma de X. fastidiosa e provavelmente o de outras bactérias em suas interações com as plantas hospedeiras fornecerá informações de extrema relevância. A curto prazo, novos genes serão caracterizados de diversas maneiras, revelando novas proteínas, novos circuitos regulatórios e quem sabe o conjunto desta informação possa ser utilizado para compreender como as bactérias causam doenças em plantas.

Os genomas destas bactérias compreendem uma gama completa de variações possíveis para estudos comparativos. Em citros, temos dois patógenos, X. fastidiosa, restrita ao xilema e $X$. axonopodis pv. citri, que afeta diversos tecidos de folhas, frutos e ramos. Outra bactéria restrita ao xilema, entretanto Gram-positiva - L. xyli subsp. xyli, que coloniza cana-de-açúcar, pode revelar similaridades importantes para a colonização do xilema. $R$. solanacearum infecta tomate e outras solanáceas e apresenta ampla gama de hospedeiros. Ademais, o número de genes conhecidos nas plantas hospedeiras está crescendo exponencialmente, através dos programas de seqüenciamento de seqüências alvos expressas (ESTs) de cana-de-açúcar, eucaliptos, citros e pelo seqüenciamento completo de Arabidopsis thaliana (planta hospedeira de $X$. campestris pv. campestris).

Embora a análise genômica tenha entrado em foco, não devemos esquecer que as bactérias estudadas causam doenças em plantas cultivadas e o prejuízo econômico ocasionado é um aspecto primário que fomenta este tipo de estudo. O que precisamos é relacionar esta moderna análise de fitopatógenos com as doenças que incitam, visando obter o controle das enfermidades ou pelo menos o convívio sem grandes perdas. A monocultura extensiva, aliada à uniformidade genética das culturas, deve favorecer a seleção de linhagens 
bacterianas com capacidade de causar doença e restringir economicamente o cultivo da hospedeira. Assim, além de pesquisas visando compreender a biologia do microrganismo, devemos preconizar o manejo adequado no ambiente agrícola, de uma forma integrada com outras práticas culturais e com o ambiente. 


\section{METODOLOGIA}

Na descrição deste trabalho, trataremos as sequiências nucleotídicas oriundas de $X$. fastidiosa como genes, embora tenham sido caracterizadas como orfs. Estas orfs apresentam a estrutura característica de um gene com i) uma região iniciadora, ii) um códon finalizador e iii) a sequiência de nucleotídeos que forma o gene, ou os aminoácidos derivados da tradução de seu respectivo RNAm, apresentam homologia com genes conhecidos de outros organismos.

Nossa abordagem neste trabalho (Figura 4) foi a de clonar os genes de interesse, como os que codificam as celulases de X. fastidiosa, em vetores de expressão da série pET (Studier \& Mofat, 1986). Neste plasmídio, o gene a ser expresso fica sob o controle do promotor T7, um promotor transcrito somente pela polimerase do RNA conhecida como T7. Linhagens de E. coli que apresentam uma cópia cromosomal desta polimerase são utilizadas para expressar o gene sob controle do promotor T7 pela indução com IPTG (Figura 5). Assim, as proteínas são expressas de maneira heteróloga em E. coli. Visando facilitar a purificação destas proteínas, pode-se adicionar fusões às extremidades amina ou carboxila terminal da proteína. No sistema empregado, a fusão é composta por uma sequiência peptídica de seis histinas, denominada de "His ${ }_{6}$ tag" a qual apresenta alta afinidade por íons metálicos como o níquel (Nilsson et al., 1997). A proteína heteróloga recombinante pode ser purificada através de cromatografia líquida de afinidade por metal e ser utilizada nos estudos de interesse.

No desenvolvimento do presente projeto, utilizamos as técnicas de clonagem e expressão segundo Ausubel et al. (1998) e Sambrock et al. (1989). A extração de DNA plasmidial está descrita no protocolo Anexo A. As técnicas que 


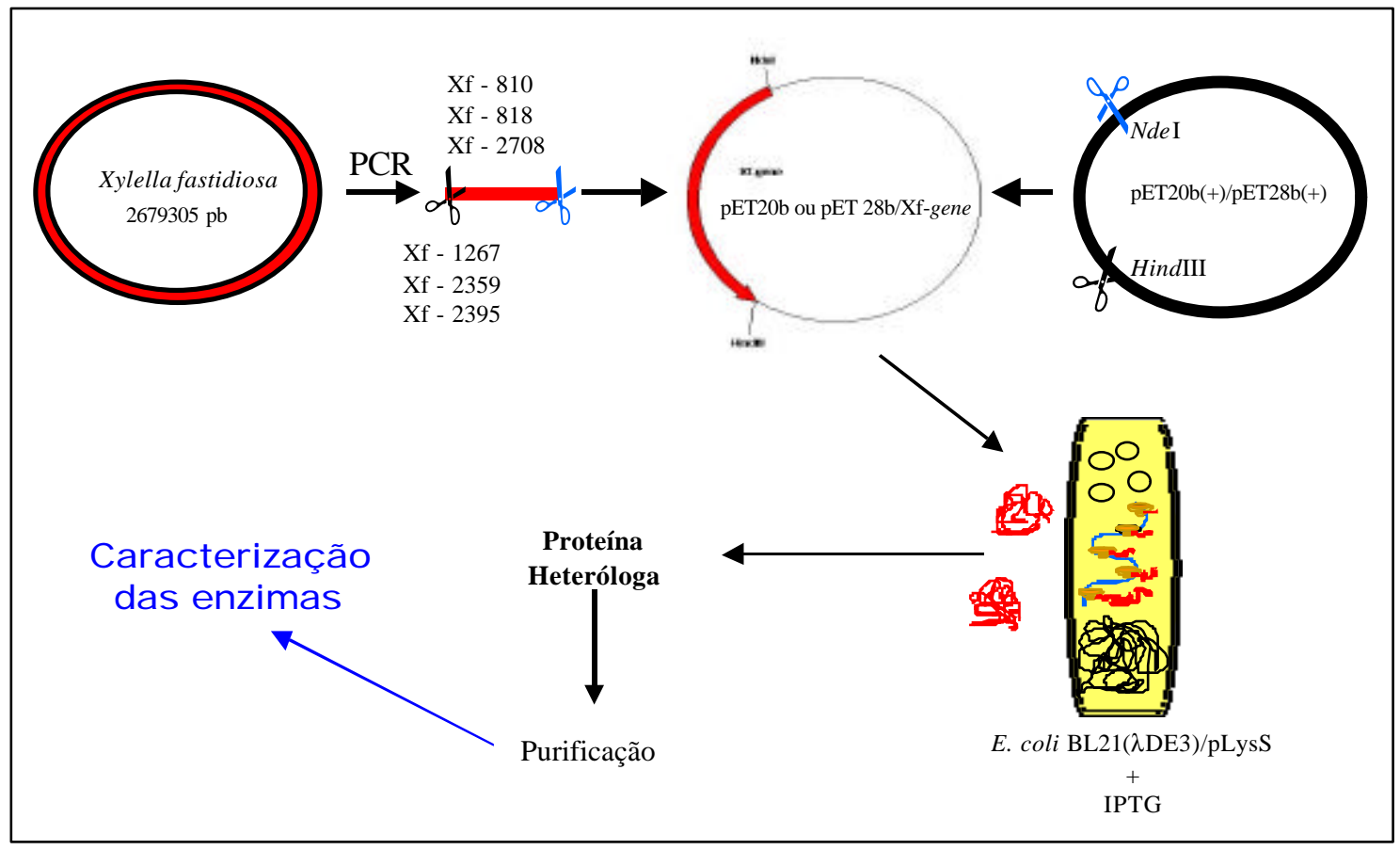

Figura 4 - Estratégia para clonagem e expressão dos genes de Xylella fastidiosa utilizando o sistema de expressão pET. Os genes, amplificados através da PCR, são clonados nos vetores de expressão pET20b/pET28b e transformados em E. coli BL21(DE3)/BL21(DE3)pLysS. Nestas linhagens o gene sob o controle do promotor T7 é superexpresso e a bactéria produz a proteína heteróloga em grandes quantidades. Esta proteína é purificada e utilizada nos ensaios de caracterização enzimática. A proteína heteróloga pode conter a cauda de hexahistidinas do plasmídio pET e ser purificada em cromatografia de afinidade por metal. 


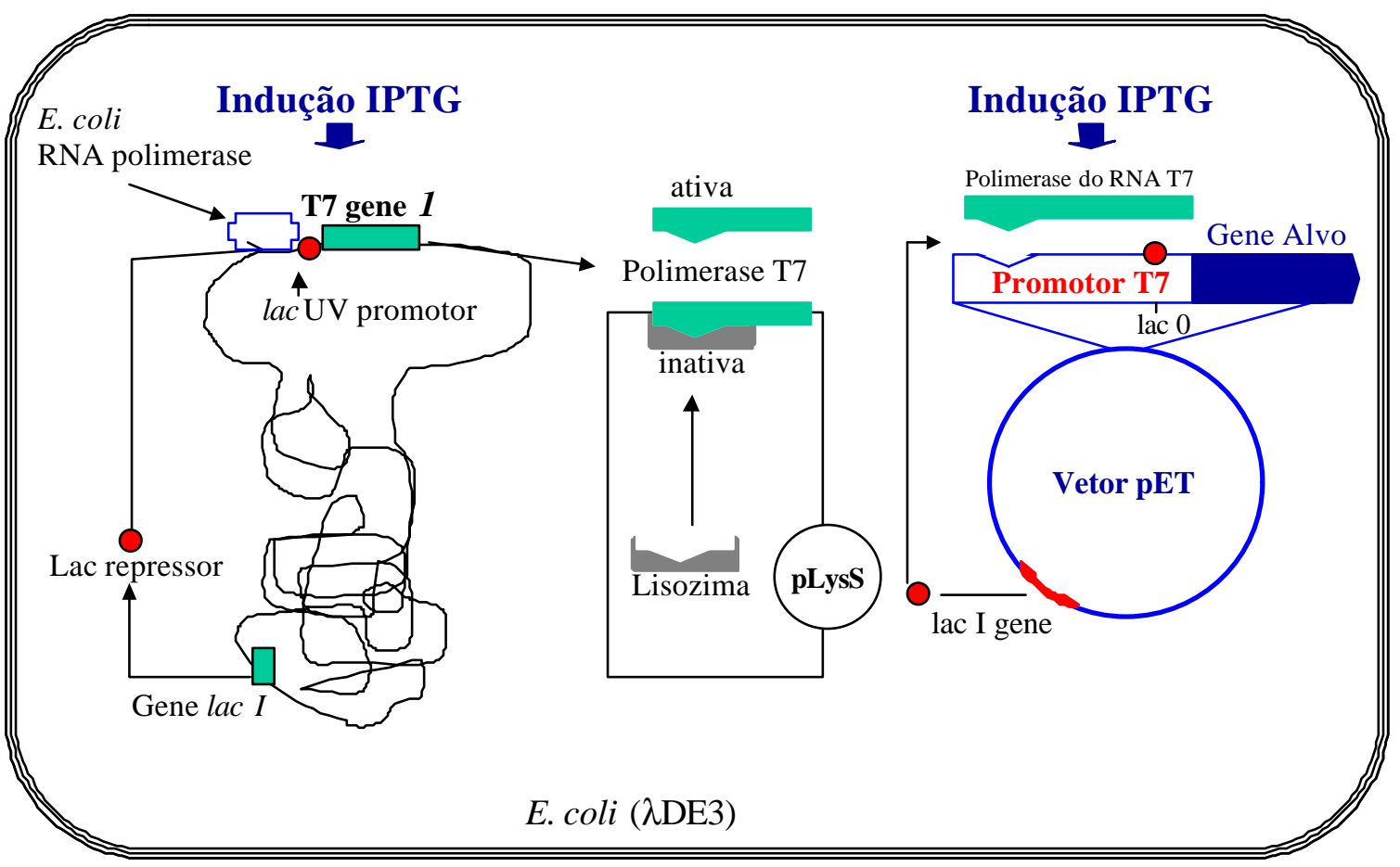

Figura 5 - Mecanismo molecular de expressão do sistema pET (plasmídio para expressão T7). A expressão é efetuada na linhagem de E. coli denominada $\lambda \mathrm{DE} 3$, a qual possui uma cópia cromosomal do gene da polimerase do RNA T7 (gene 1 do fago T7). O vetor de expressão pET contendo o gene a ser expresso sob o controle do promotor T7, é inserido nesta linhagem e mantido pela presença do gene de resistência a antibiótico. O gene da polimerase do RNA T7 está sob o controle do promotor lacUV e sob indução com IPTG é expresso e seletivamente transcreve o gene sob o controle do promotor T7 (o IPTG não permite a ligação do repressor lac). A presença de pLysS (opcional) garante a produção da lisozima T7, a qual na ausência de indução com IPTG, reprime a expressão pela polimerase T7. A polimerase T7 é altamente processiva e transcreve somente o gene sob o controle do promotor T7, o qual não é encontrado em E. coli. 
envolvem o manuseio de soluções proteicas, a menos que de outra forma indicada, seguiram as sugestões contidas em Scopes (1982) e Ausubel et al. (1998).

\subsection{Bactérias e plasmídios}

As estirpes das bactérias e os plasmídios que foram utilizados neste trabalho estão listados nas Tabela 3 e Tabela 4, respectivamente. A construção dos plasmídios derivados deste trabalho e listados na Tabela 4 será detalhada no ítem 3.3.

Tabela 3. Estirpes de Escherichia coli.

\begin{tabular}{|c|c|c|}
\hline Estirpes & Genótipo/fenótipo & Referência/Origem \\
\hline DH5 $\alpha$ & 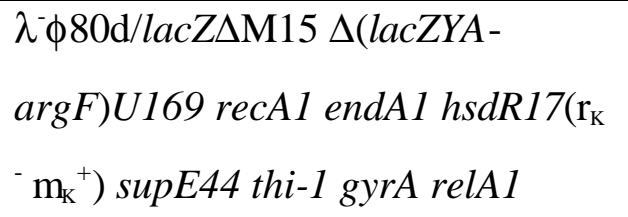 & Hanahan et al., 1983 \\
\hline BL21 ( $\lambda$ DE3) & $F^{-}, o m p T, h s d S_{\mathrm{B}},\left(r_{\mathrm{B}}^{-}, m_{\mathrm{B}}^{-}\right) d c m, g a l$ & $\begin{array}{l}\text { Novagen; Studier \& } \\
\text { Moffatt, } 1986 .\end{array}$ \\
\hline BL21 ( $\lambda$ DE3) pLysS & $\begin{array}{l}F^{-}, o m p T, h s d S_{\mathrm{B}},\left(r_{\mathrm{B}}^{-}, m_{\mathrm{B}}^{-}\right) d c m, \\
g a l, \mathrm{~cm}^{\mathrm{R}}, \text { lisozima }+\end{array}$ & $\begin{array}{l}\text { Novagen; Studier, } \\
1991 .\end{array}$ \\
\hline
\end{tabular}

\subsubsection{Cultivo de $E$. coli}

As culturas de E. coli foram crescidas a temperatura de $37^{\circ} \mathrm{C}$, a menos que de outra forma indicado. Usualmente colônias cultivadas em meio solidificado foram mantidas durante a noite em incubadora a $37{ }^{\circ} \mathrm{C}$. Colônias crescidas em meio líquido destinadas a extração de plasmídios também foram crescidas durante uma noite, entre 12 e 18 h, em incubadora com agitação orbital, ajustada entre 180 e 320 rpm dependendo do volume de meio utilizado para o crescimento das células.

Todo o material contendo células de E. coli empregado no presente trabalho foi esterilizado após sua utilização. 
Tabela 4. Lista dos plasmídios produzidos ou utilizados.

\begin{tabular}{|c|c|c|c|}
\hline Plasmídios & Genótipo/fenótipo & Referência/Origem & Estrutura da proteína ${ }^{1}$ \\
\hline pET20b(+) & Vetor de expressão. Amp ${ }^{\mathrm{R}}$, lacI, f1 & Novagen & \\
\hline pET28b(+) & Vetor de expressão. Can', lacI, f1 & Novagen & \\
\hline pNAW1 & $\begin{array}{l}\text { Gene Xf } 810 \text { de } X \text {. fastidiosa clonado em } \\
\text { pET20b nos sítios HindIII NdeI }\end{array}$ & Este trabalho & Nativa \\
\hline pNAW2 & $\begin{array}{l}\text { Gene Xf } 810 \text { de } X \text {. fastidiosa clonado em } \\
\text { pET28b nos sítios HindIII NdeI }\end{array}$ & Este trabalho & $\mathrm{His}_{6} \operatorname{tag} \mathrm{N}-$ \\
\hline pNAW3 & $\begin{array}{l}\text { Gene Xf } 818 \text { de } X \text {. fastidiosa clonado em } \\
\text { pET20b nos sítios HindIII NdeI }\end{array}$ & Este trabalho & Nativa \\
\hline pNAW4 & $\begin{array}{l}\text { Gene Xf } 818 \text { de } X \text {. fastidiosa clonado em } \\
\text { pET28b nos sítios HindIII NdeI }\end{array}$ & Este trabalho & $\mathrm{His}_{6} \operatorname{tag} \mathrm{N}-$ \\
\hline pNAW5 & $\begin{array}{l}\text { Gene Xf } 2708 \text { de } X \text {. fastidiosa clonado em } \\
\text { pET20b nos sítios HindIII NdeI }\end{array}$ & Este trabalho & Nativa \\
\hline pNAW6 & $\begin{array}{l}\text { Gene Xf } 2708 \text { de X. fastidiosa clonado em } \\
\text { pET20b nos sítios HindIII NdeI }\end{array}$ & Este trabalho & $\mathrm{His}_{6} \operatorname{tag} \mathrm{C}_{-}$ \\
\hline pNAW13 & $\begin{array}{l}\text { Gene Xf } 818 \text { de } X \text {. fastidiosa clonado em } \\
\text { pET20b nos sítios HindIII NdeI }\end{array}$ & Este trabalho & $\mathrm{His}_{6} \operatorname{tag} \mathrm{C}_{-}$ \\
\hline
\end{tabular}

${ }^{1}$ Refere-se à construção do plasmídio (item 3.3) em relação a manutenção da proteína original, ou com cauda de histidina $\left(\right.$ His $_{6}$ tag) na extremidade amina (N-) ou carboxila (C-) terminal da proteína transcrita a partir do gene em X. fastidiosa. 
Os plasmídios utilizados neste trabalho (Tabela 4) foram armazenados em clones de E. coli em ultracongelador a $-80^{\circ} \mathrm{C}$. Culturas de E. coli crescidas durante uma noite foram misturadas em igual proporção com uma solução de glicerol $65 \%$ (v/v), $\mathrm{MgSO}_{4}$ $100 \mathrm{mM}$ em Tris- $\mathrm{HCl}$ pH 8,0 25 mM esterilizada por autoclavagem, misturadas e congeladas. Quando necessário, estes clones foram repicados em meio LB solidificado (descrito em 3.1.2) com antibiótico apropriado e colônias isoladas foram crescidas para um determinado fim.

As linhagens de E. coli (Tabela 3) foram armazenadas como descrito acima e quando necessário foram crescidas em meio LB solidificado. Estas três linhagens foram utilizadas para a preparação de células eletrocompetentes. Neste caso, uma colônia isolada de E. coli cultivada em meio sólido foi transferida para $5 \mathrm{~mL}$ de meio $\mathrm{LB}$ e crescida durante 12 a $14 \mathrm{~h}$ a $37{ }^{\circ} \mathrm{C}$ e $220 \mathrm{rpm}$. Este volume foi inoculado em $250 \mathrm{~mL}$ de meio LB aquecido a $37{ }^{\circ} \mathrm{C}$ e mantido de 2 a $3 \mathrm{~h}$ a $37{ }^{\circ} \mathrm{C}$ e $220 \mathrm{rpm}$. Estas células foram utilizadas para preparação de células eletrocompetentes.

\subsubsection{Meio de cultura e antibióticos}

No decorrer dos trabalhos utilizamos o meio LB (Luria Bertani) na seguinte formulação: triptona $1 \%$; extrato de levedura 0,5\%; $\mathrm{NaCl}$ 0,5\% (m/v); $\mathrm{NaOH} 1 \mathrm{M} 1 \mathrm{~mL} \mathrm{~L}$

1. O pH do meio ficava entre 6,8 e 7,1. Para a confecção de meio sólido foi adicionado ágar a 1,8 \% (m/v), previamente à autoclavagem. O meio de cultura, com ou sem adição de ágar, foi esterilizado através de autoclavagem a $121^{\circ} \mathrm{C}(1 \mathrm{~atm})$ durante 15 a $20 \mathrm{~min}$, dependendo do volume distribuído em cada frasco.

Após a esterilização, o meio com ágar foi resfriado até $55^{\circ} \mathrm{C}$ e o antibiótico foi adicionado na quantidade indicada para cada caso. Este meio foi distribuído em placa de petri e armazenado a $4{ }^{\circ} \mathrm{C}$. O meio líquido suplementado com antibiótico na quantidade indicada foi armazenado a $4{ }^{\circ} \mathrm{C}$ até o momento de utilização. Toda manipulação do meio de cultura após esterilização foi efetuada em capela de fluxo laminar, sob condição asséptica.

Nos ensaios de expressão heteróloga de proteínas (itens 3.4 e 3.5), o meio foi 
suplementado com glicose a 0,1\% (m/v), previamente à autoclavagem.

Os antibióticos utilizados foram dissolvidos apropriadamente como segue: ampicilina foi dissolvida em mistura de água: etanol (1:1 v/v) na concentração de $100 \mathrm{mg} \mathrm{mL}^{-1}$. Sulfato de canamicina foi dissolvida em água ultrapura (Milli Q; Millipore) esterilizada na concentração de $50 \mathrm{mg} \mathrm{mL}^{-1}$. Cloranfenicol foi dissolvido em etanol puro a $10 \mathrm{mg} \mathrm{mL}^{-1}$. Nos ensaios estão descritas as concentrações utilizadas dos antibiótico no meio de cultura.

\subsubsection{Extração de DNA cosmidial e plasmidial}

Os genes de $X$. fastidiosa utilizados no presente trabalho foram clonados a partir de cosmídeos utilizados no programa de seqüenciamento do genoma da bactéria, efetuado pela rede ONSA (http://watson.fapesp.br/onsa/Genoma3.htm). Os cosmídeos foram fornecidos pelo Prof. Jesus Ferro (UNESP/Jaboticabal - SP) e podem ser encontrados juntamente com os outros cosmídeos utilizados no seqüenciamento da X. fastidiosa, assim como clones derivados de outros projetos integrados pela rede ONSA, no Banco Brasileiro de Clones (http://www.bcccenter.fcav.unesp.br/). Na Tabela 5 podem ser consultados os códigos de cada cosmídeo utilizados como molde para amplificação dos genes através da PCR (item 3.3.3) e as características dos genes.

As colônias de E. coli foram crescidas no meio LB e alíquotas de 1,5 mL foram transferidas para microtubos de centrífuga para extração do DNA cosmidial ou plasmidial. O protocolo de lise alcalina empregado neste trabalho está descrito no Anexo A. Nos ensaios descritos nos ítens 3.3.4 e 3.3.5, para cada colônia de E. coli, foi efetuada a extração de DNA plasmidial utilizando $3 \mathrm{~mL}$ de meio de cultura para cada extração. Assim, 1,5 $\mathrm{mL}$ de meio com as células foi centrifugado $2 \mathrm{~min}$ a $13400 \mathrm{~g}$. Ao pelete resultante foram adicionados mais $1,5 \mathrm{~mL}$ do mesmo meio, sendo o pelete ressupenso em vortex e a centrifugação repetida. O restante da processo de extração do DNA plasmidial segue como descrito. Empregamos esta modificação visando extrair uma quantidade de plasmídios apropriada para as análises de restrição. Os plasmídios de expressão são plasmídios de baixo número de cópias, o que reduz o rendimento por grama de células utilizado se comparado 
com plasmídios de alto número de cópias, empregado para clonagem, como é o caso do pUC18.

Tabela 5. Características das celulases encontradas em Xylella fastidiosa 9a5c.

\begin{tabular}{|c|c|c|c|c|c|}
\hline \multirow[t]{2}{*}{ Gene $^{1}$} & \multicolumn{2}{|c|}{ Coordenada $^{2}$} & \multirow{2}{*}{$\begin{array}{c}\text { Bases } \\
\text { (pb) }\end{array}$} & \multicolumn{2}{|c|}{ Proteína $^{3}$} \\
\hline & Cromosomo & Cosmídeo & & aa & $\mathrm{kDa}$ \\
\hline \multicolumn{6}{|c|}{ Endoglicanases } \\
\hline$X f-810$ & $\begin{array}{l}761713 \\
763410 \mathrm{U}\end{array}$ & XF-07H04-gl14 & 1698 & 565 & 61,6 \\
\hline$X f-818$ & $\begin{array}{l}769640 \\
771418 \mathrm{C}\end{array}$ & XF-07H04-gl04 & 1779 & 592 & 60,0 \\
\hline$X f-2708$ & $\begin{array}{l}2588067 \\
2589137 \mathrm{U}\end{array}$ & XF-07B07-gl22 & 1071 & 356 & 39,3 \\
\hline \multicolumn{6}{|c|}{ Celobiohidrolase } \\
\hline$X f-1267$ & $\begin{array}{l}1222318 \\
1224369 \mathrm{C}\end{array}$ & XF-02D03-gl63 & 2052 & 683 & 70,9 \\
\hline \multicolumn{6}{|l|}{$\beta$-glicosidase } \\
\hline$X f-439$ & $\begin{array}{l}448471 \\
450693 \mathrm{U}\end{array}$ & XF-07A10-gl45 & 2223 & 740 & 80,3 \\
\hline
\end{tabular}

1 Numeração referente aos genes encontrados em X. fastidiosa 9a5c (Simpson et al., 2000);

2 A coordenada cromosomal refere-se a posição do gene no genoma de $X$. fastidiosa 9a5c (http://aeg.lbi.ic.unicamp.br/xf/ ). A coordenada cosmidial referese ao cosmídeo utilizado durante o seqüenciamento e ao gene (gl) encontrado no cosmídeo;

3 aa - número de aminoácidos da proteína, incluindo peptídio sinal. Massa teórica calculada a partir da estrutura primária da proteína com Compute pI/MW (http://www.expasy.ch/tools/pi_tool.html / Nielsen et al., 1997).

\subsection{Análise dos genes relacionados a celulases em $X$. fastidiosa}

Findo o seqüenciamento do genoma da bactéria fitopatogênica X. fastidiosa 9a5c pela rede ONSA, foi efetuada a anotação dos genes possivelmente presentes neste organismo, utilizando algoritmos computacionais apropriados (Simpson et al., 2000). 
Entretanto, o trabalho aqui apresentado iniciou-se durante a fase de seqüenciamento $\left(2^{\circ}\right.$ semestre de 1998), quando o trabalho de anotação estava apenas no início. Desta forma, utilizando os dados de seqüenciamento disponibilizados pela rede ONSA, procedemos a uma análise independente em busca de genes com homologia de seqüência a genes envolvidos no processo patológico em bactérias fitopatogênicas. Para este fim utilizamos o "BLAST" (http://www.ncbi.nlm.nih.gov/BLAST/), um algoritmo de alinhamento de seqüências (Altschul et al., 1990), empregando também a opção deste programa, o PSI-BLAST (Altschul et al., 1997).

Foi observada uma pequena homologia com a endoglicanase engXCA de Xanthomonas campestris pv. campestris [acesso no GenBank = M32700/P19487] (Gough et al., 1990) e com a liase de pectato de Pseudomonas viridiflava [gi|463195 ou AAA20829] (Liao et al., 1994). Estas bactérias são causadoras da podridão negra das crucíferas e podridão mole do alface, respectivamente. A similaridade a estas proteínas fomentou a busca por outros genes relacionados a este grupo, de enzimas degradadoras da parede celular vegetal.

As sequiências nucleotídicas obtidas no banco de dados da X. fastidiosa (XfDB) e no ORF Editor (ferramentas disponíveis para os integrantes do projeto Genoma/ONSA àquela época) foram analisadas com os programas ORFinder (http://www.ncbi.nlm.nih.gov/gorf/gorf.html), Blast (Altschul et al., 1990) e Blast two sequences (Tatusova \& Madden, 1999; http://www.ncbi.nlm.nih.gov/blast/bl2seq/bl2.html) com o intuito de encontrar similaridades por vezes renegadas devido a baixa homologia ou devido ao surgimento de novos genes nos banco de dados.

Após a montagem do XfDB e do avanço no processo de anotação dos genes, foram encontradas novos genes relacionadps com EDPCV, como por exemplo, celobiohidrolase, poligalacturonase e endoxilanases, além de novas endoglicanases. Para termos certeza de que todas as possíveis EDPCV estivessem identificadas, efetuamos buscas de similaridade "blast" com todas as proteínas encontradas na "homepage" "Carbohydrate 
Active enZYmes" (Coutinho \& Henrissat, 1999; http://afmb.cnrs-mrs.fr/CAZY/). Este banco de dados cataloga todas as glicosidases conhecidas, organizando-as por famílias. Estas famílias, atualmente 87, são estruturadas com base na similaridade de sequiência dos aminoácidos dos domínios catalíticos destas enzimas que degradam, modificam ou criam ligações glicosídicas (EC 3.2.1.-).

De posse da informação dos genes de interesse presentes no genoma de $X$. fastidiosa, procedemos a etapa seguinte (descrita a partir do item 3.3) utilizando a sequiência de nucleotídios disponível do banco de dados da rede ONSA para o genoma desta bactéria (http://aeg.lbi.ic.unicamp.br/xf/) referentes aos genes Xf - 810, Xf - 818, Xf - 1267 e Xf 2708.

\subsection{Clonagem dos genes}

Optamos por clonar os genes nos plasmídios pET por representarem um sistema eficiente e amplamente utilizado, o que pode ser comprovado pelo elevado número de trabalhos publicados com este sistema. Opcionalmente, este sistema permite a fusão de cauda de seis histidinas (His ${ }_{6}$ tag ou His tag), o que pode ser utilizado para a purificação da proteína recombinante expressa heterologamente. Neste sistema, o gene de interesse é clonado sob o controle do promotor T7. Dentre os diversos vetores construídos com esta finalidade, os plasmídios pET20 e pET28 apresentavam as características necessárias para efetuarmos a expressão dos genes selecionados em E. coli.

A organização do sítio de clonagem múltipla é semelhante em pET20 e pET28. Utilizando como sítio de clonagem os sítios de restrição das enzimas NdeI e HindIII, podemos clonar o mesmo fragmento em ambos os plasmídios. Abaixo segue uma breve descrição das características de ambos os plasmídios e da estratégia de clonagem.

Os plasmidios da série pET apresentam geralmente três variantes para cada plasmídio, por exemplo, pET28a, pET28b e pET28c, diferindo um dos outros apenas pelo quadro de leitura para transcrição e tradução do gene clonado. Isto facilita a clonagem de um 
fragmento que possua sítios de restrição coincidentes com o sítio de clonagem múltipla. No presente trabalho, amplificamos os genes de interesse através da PCR, introduzindo sítios de restrição para a enzima $N d e$ I no início do gene (coincidente com o ATG inicial) e sítio para HindIII sobre o códon de finalização do gene. O plasmídio pET28 possui um gene que confere resistência a canamicina e o gene clonado sob o controle do promotor $\mathrm{T} 7$ pode apresentar a cauda de histidina na extremidade $\mathrm{N}$ ou $\mathrm{C}$-terminal da proteína. No caso de produto $\mathrm{c} \bullet \mathrm{m}$ cauda de histidina $\mathrm{N}$-terminal, esta fusão pode ser clivada da proteína recombinante com o auxílio de trombina, pois há um sítio de clivagem para esta enzima entre o códon de início do gene clonado e o His 6 tag N-terminal. Para o caso da utilização do His tag C-terminal o plasmídio não apresenta sítios para clivagem com enzimas que permitam retirar a fusão da proteína.

O plasmídio pET20b apresenta a mesma estrutura para clonagem, possuindo como marcador seletivo o gene para $\beta$-lactamase conferindo resistência à ampicilina. Esta série apresenta a possibilidade de clonagem do gene sob o controle do promotor T7 com adição de cauda de histidina à extremidade C-terminal. Entretanto, esta fusão não apresenta sítio para clivagem da fusão na proteína recombinante. Outra característica deste plasmídio é uma sequiência denominada pelB para potencial localização periplasmática do produto protéico, uma sequiência peptídica sinal $\mathrm{N}$-terminal clivável encontrada em bactérias Gramnegativas.

Desta forma, utilizamos o plasmídio pET20b(+), com 3716 pb, para clonar os genes de interesse de duas formas: na primeira foi mantida a estrutura original da proteína, denominada de nativa (item 3.3.4.1). Assim, a tradução inicia-se no ponto correspondente ao ATG original do gene, terminando com o códon de finalização presente no gene. Nesta conformação nativa não há incorporação da fusão His tag. Na segunda forma, foi mantido o ponto inicial de tradução, mas o códon de finalização foi alterado para que a tradução continuasse na sequiência do vetor, produzindo uma cauda hexahistidinas na extremidade Cterminal (item 3.3.4.2). Em ambos casos não foi incorporada a sequiência pelB. 
A outra abordagem foi utilizar o plasmídio pET28b(+), com 5368, para clonar os genes de interesse com a cauda de seis histidinas na extremidade $\mathrm{N}$-terminal da proteína (item 3.3.5), mantendo o códon de finalização original do gene. Desta forma, genes clonados em pET20b(+) para produção da proteína original podem ser subclonados nos mesmos sítios de restrição em pET28b(+), acrescidos da fusão de seis histidinas N-terminal clivável com trombina.

Em todas as etapas (item 3.3) de preparação e utilização dos reagentes foram utilizados materiais e reagentes esterilizados e água ultrapura esterilizada.

\subsubsection{Desenho dos iniciadores}

A escolha da sequiência de nucleotídeos dos iniciadores foi efetuada tomando por base a sequiência original dos genes e os sítios de restrição existentes nestas sequiências, bem como nos plasmídios de expressão. As sequiências foram analisadas em programas de computador adequados e a síntese foi efetuada em escala de 50 nmoles pela Operon Technologies, Inc (Alameda, CA - USA) ou pela Life Technologies do Brasil Ltda (São Paulo, SP).

\subsubsection{Iniciadores para clonagem}

Com o objetivo de amplificar os genes de interesse para a subclonagem nos plasmídios pET20b(+) e pET28b(+), foram sintetizados oligonucleotídeos (iniciadores) específicos para os genes em questão. Nestes iniciadores foram inseridos sítios de restrição para as enzimas NdeI, SalI e HindIII (Scharf et al., 1986; Mullis \& Faloona, 1990). Nos iniciadores, desenhados de tal forma a anelar no sentido da transcrição, denominados de "forward", foram inseridos sítios para as enzimas SalI e NdeI. Nos iniciadores "reverse", que são complementares à porção 3' do gene, foi inserido sítio de restrição para a enzima HindIII. Além das bases necessárias para formar os sítios de restrição para estas enzimas, foram adicionados nucleotídeos extras, preferencialmente GC para facilitar a amplificação do gene de interesse (Sheffield et al., 1989) e para facilitar a digestão do fragmento amplificado 
pelas enzimas de restrição (Ausubel et al., 1998). A escolha por NdeI e HindIII justifica-se pois os genes amplificados desta maneira podem se clonados em pET20b(+) e pET28b(+). Adicionalmente inserimos o sítio de restrição para SalI, sobrepondo NdeI de forma a permitir a clonagem no vetor de expressão pMal (Stratagene), utilizando SalI e HindIII. Esta escolha foi feita como uma alternativa a ser efetuada caso o sistema empregado não fosse eficiente.

Na construção dos iniciadores, foram selecionados de 14 a 19 nucleotídeos complementares ao gene de interesse nas extremidades 5' e 3'. Os sítios de restrição para as enzimas NdeI e SalI foram adicionados à extremidade 5' das seqüências, de forma a permitir a clonagem em pET20b(+), pET28b(+) e pMal sem interferir no quadro de leitura do gene para expressão nos plasmídios. Nos iniciadores em que objetivou-se utilizá-los para clonagem com adição de His $_{6}$ tag à proteína (vetor pET20b e hexahistidina C-terminal), foi alterado o códon de terminação original do gene, como no caso do iniciador R356His, utilizado para amplificar o gene Xf - 2708 (plasmídio pNAW6). Como já descrito, os genes clonados em pET20(+) para produzirem a proteína nativa podem ser subclonados em pET28b(+) produzindo a fusão His tag na extremidade N-terminal da proteína.

Os genes de interesse foram previamente analisados com o programa Clone (v. 3.11 - Scientific \& Educational Software) para encontrar os sítios de restrição presentes na sequiência. As seqüências dos iniciadores, apresentando entre 23 e 32 nucleotídeos, foram então analisadas no programa Oligo (v.2.0 - NAR) para observarmos a formação de dímeros e grampos (auto-complementariedade). Este mesmo programa calcula a temperatura de dissociação destas estruturas, quando formadas.

Escolhemos assim, as melhores seqüências de forma a evitar a formação destas estruturas e de maneira a ter um par de iniciadores (F e R) com uma temperatura de anelamento o mais próximo possível uma da outra. A sequiência dos iniciadores pode ser observada na Tabela 6, onde está destacado em negrito o sítio de restrição no iniciador a ser incluído no gene amplificado. Sublinhado está a sequiência complementar ao gene como seqüenciado em X. fastidiosa (Simpson et al., 2000; http://aeg.lbi.ic.unicamp.br/xf/). 


\subsubsection{Iniciadores para seqüenciamento}

Com o intuito de seqüenciarmos os genes clonados nos vetores de expressão pET20b(+) e pET28b(+) foram empregados os iniciadores promotor T7 e terminador T7, os quais anelam nas regiões flanqueadoras do sítio de clonagem múltipla em pET20b(+) e pET28b(+). Em adição a estes iniciadores foram efetuadas reações de amplificação com os mesmos iniciadores utilizados para sua amplificação visando a clonagem. Nos genes que apresentam aproximadamente $1 \mathrm{~kb}$ ou acima deste tamanho foi necessário a construção de iniciadores internos para permitir o completo seqüenciamento da região compreendida entre as regiões de anelamento dos iniciadores promotor T7 e terminador T7 (Figura 6). Desta forma foram sintetizados dois iniciadores internos para os genes Xf - 810 e Xf - 818 e um iniciador para o gene Xf - 2708 ( Tabela 7).

Tabela 6. Iniciadores utilizados para amplificar os genes através da PCR e posterior clonagem no vetor de expressão pET20b(+) ${ }^{1}$.

\begin{tabular}{|c|c|c|c|}
\hline Iniciador & Gene & Sequiência $\left(5^{\prime} \rightarrow 3^{\prime}\right)^{2}$ & Plasmídio $^{3}$ \\
\hline F588LNd & $\mathrm{Xf}-810$ & CAACACATATGAGGTATGAGATGCG & pNAW1 \\
\hline R588LHd & & GTCGCAAGCTTATTCGGAAAACTGGAC & \\
\hline F592Sl & Xf -818 & CCGGTCGACATATGTCGTTTTCCAAACAC & pNAW3 \\
\hline R592Hd & & GGAAAATAAGCTTCAATAGTTTGAAC & \\
\hline R592His & & GGTAAATAAGCTTCAGATAGTTTGAACAG & pNAW13 \\
\hline F356Nd & $X f-2708$ & САТССАTATGCСТАТTTCСТTTC & pNAW5 \\
\hline F356Hd & & GGGAAGCTTATTTGTGGATTTTAGTG & \\
\hline $\mathrm{F} 356 \mathrm{Nd}$ & $X f-2708$ & САTСCATATGCCTATTTCСТTTC & pNAW6 \\
\hline R356His & & GGGAAGCTTATTCTTGTGGATTTTAGTG & \\
\hline F683Nd & $X f-1267$ & CGGTCGACATATGTCTGTTTCACTATTAG & - \\
\hline R683His & & CGGAAGCTTCACATAGTTTGCACAGAA & \\
\hline
\end{tabular}

1 Letras em negrito na seqüência denotam sítio de restrição inserido no iniciador; Nucleotídeos sublinhados são idênticos aos encontrados nos genes;

2 Seqüência do iniciador nomeado na primeira coluna;

3 Plasmídios descritos na Tabela 4. 


\subsubsection{Amplificação via PCR}

Os iniciadores liofilizados foram diluídos em água e posteriormente congelados e mantidos a $-20{ }^{\circ} \mathrm{C}$ até sua utilização. Inicialmente foram testadas variações na concentração de iniciadores, cloreto de magnésio e dNTPs e a amplificação consistiu dos seguintes reagentes, descrita em condições otimizadas:

\begin{tabular}{|c|c|}
\hline 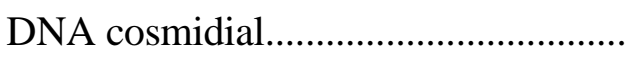 & $5 \mathrm{uL}(\sim 50 \mathrm{ng})$ \\
\hline Iniciador "Forward", ................................ & 0,2 pmoles \\
\hline Iniciador "Reverse"..... & 0,2 pmoles \\
\hline 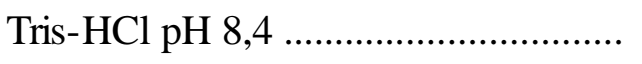 & $20 \mathrm{mM}$ \\
\hline 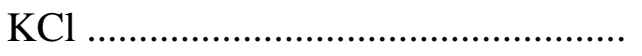 & $50 \mathrm{mM}$ \\
\hline 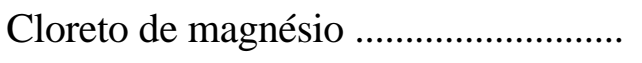 & $1,5 \mathrm{mM}$ \\
\hline 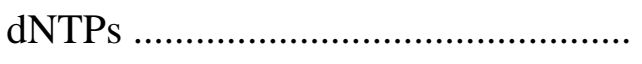 & $200 \mu \mathrm{M}$ de cada \\
\hline Taq DNA polimerase (Gibco BRL) ..... & $1,5 \mathrm{U}$ \\
\hline
\end{tabular}

Tabela 7. Iniciadores utilizados para o seqüenciamento dos genes nos plasmídios pET20b(+) e pET28b(+).

\begin{tabular}{llc}
\hline Iniciador & Seqüência $\left(5^{\prime} \rightarrow 3^{\prime}\right)$ & Plasmídio/Gene $^{1}$ \\
\hline Promotor T7 & TAATACGACTCACTATAGGG & pET20b/pET28b \\
Terminador T7 & TGCTAGTTATTGCTCAGCGGT & pET20b/pET28b \\
810intN & GGGCGTGGACTTGGC & Xf -810 \\
810intC & CCAGCATCAATGCTCC & Xf -810 \\
818intN & GCGTCATCGGCTTGG & Xf -818 \\
818intC & CGCGCACGTGATTCC & Xf -818 \\
2708intC & CCCTACAGTTTGCC & Xf -2708 \\
\hline
\end{tabular}

1 Cada iniciador foi utilizado para amplificação no plasmídio denominado (sítio de anelamento no próprio plasmídio) ou seu derivado, ou para amplificação da porção interna do gene indicado. 
As diferentes combinações de iniciadores (Tabela 6) para os genes Xf - 810, Xf -818 , Xf - 1267 e Xf - 2708 e o restante dos reagentes foram amplificadas em termociclador (Modelo PTC-100; MJ Research, Inc. Watertown, MA - USA), onde foram utilizadas as temperatura de anelamento a $60{ }^{\circ} \mathrm{C}$ e amplificação a $72{ }^{\circ} \mathrm{C}$, organizadas da seguinte maneira:

\begin{tabular}{|c|c|c|}
\hline $94^{\circ} \mathrm{C}$ & $180 \mathrm{~s}$ & \\
\hline $94{ }^{\circ} \mathrm{C}$ & $30 \mathrm{~s}$ & \\
\hline $60{ }^{\circ} \mathrm{C}$ & $60 \mathrm{~s}$ & 35 ciclos \\
\hline $72{ }^{\circ} \mathrm{C}$ & $120 \mathrm{~s}$ & \\
\hline $72{ }^{\circ} \mathrm{C}$ & $10 \mathrm{~min}$ & \\
\hline $4^{\circ} \mathrm{C}$ & & \\
\hline
\end{tabular}

Uma alíquota de $10 \mathrm{uL}$, contendo fragmentos de DNA amplificados através da reação em cadeia da polimerase (PCR), foi analisada em gel de agarose $0,8 \%(\mathrm{~m} / \mathrm{v})$ em tampão Tris $40 \mathrm{mM}$, ácido acético $40 \mathrm{mM}$ e EDTA $1 \mathrm{mM}$ (TAE). O restante do DNA foi purificado com acetato de sódio e etanol (Anexo B).

Os genes de $X$. fastidiosa assim amplificados foram utilizados para clonagem de acordo com os itens 3.3.3 e 3.3.4.

\subsubsection{Análise dos transformantes}

O DNA plasmidial das colônias selecionadas foi extraído de acordo com protocolo padrão (Anexo A) e posteriormente digerido com enzimas de restrição para análise da presença do inserto no plasmídio.

Dependendo da combinação plasmídio / gene de X. fastidiosa, os plasmídios resultantes foram digeridos com a combinação HindIII - XbaI ou HindIII - XhoI. Estas enzimas reconhecem sítios de restrição que flanqueiam os genes clonados, permitindo distinguir entre os plasmídios oriundos de religação daqueles que possuem o inserto desejado. 
Em alguns casos esta análise foi efetuada com HindIII e NdeI. Entretanto a enzima NdeI requer um DNA de boa qualidade, ou limpo, para uma eficiente digestão, dificultando a análise do resultado da digestão de plasmídio resultante de uma minipreparação.

Ademais, o DNA plasmidial destes clones selecionados foi amplificado através da PCR, utilizando-se os iniciadores promotor T7 e terminador T7, de acordo com as condições descritas em 3.3.2, visando confirmar o tamanho do inserto. Clones que apresentaram o inserto de tamanho correspondente ao gene clonado foram armazenados com glicerol em ultracongelador a $-80{ }^{\circ} \mathrm{C}$. A confirmação final foi efetuada através de seqüenciamento, como descrito em 3.3.6.

\subsubsection{Clonagem dos genes Xf-810, Xf-818 e Xf-2708 no plasmídio de expressão pET20b}

O plasmídio pET20b(+) foi digerido com $2 \mathrm{U}$ de cada uma das enzimas de restrição, NdeI e HindIII em volume de reação de $25 \mu \mathrm{L}$, com cerca de $2 \mu \mathrm{g}$ de vetor, durante $4,5 \mathrm{~h}$ a $37^{\circ} \mathrm{C}$. O produto da digestão foi submetido a eletroforese em gel de agarose $0,8 \%$ (TAE) e o vetor linearizado excisado do gel. O fragmento de agarose contendo o DNA foi pesado e utilizado para extração de acordo com o protocolo descrito no Anexo C.

\subsubsection{Construção dos plasmídios para expressão das proteínas nativas}

Os genes Xf - 810, Xf - 818 e Xf - 2708 de X. fastidiosa amplificados de acordo com o ítem 3.3.2 foram utilizados para clonagem no plasmídio pET20b(+). Nestas construções, foi mantida a estrutura original do gene, de forma a produzir a proteína como se estivesse sendo expresa em $X$. fastidiosa. Nesta condição, a proteína mesmo sendo expressa de maneira heteróloga será descrita como proteína nativa, em oposição à proteína recombinante que apresenta cauda de histidina C-terminal (3.3.4.2) ou N-terminal (3.3.5).

Os genes amplificados através da PCR e após precipitação para limpeza (item 3.3.2), foram dissolvidos em água e digeridos com 2 U de $N d e \mathrm{I}$ e 2 U de HindIII, em tampão 
Tris- $\mathrm{HCl} \mathrm{pH}$ 8,0 $50 \mathrm{mM}, \mathrm{MgCh}_{2} 10 \mathrm{mM}$ e $\mathrm{NaCl} 50 \mathrm{mM}$ durante 4,5 h a $37^{\circ} \mathrm{C}$, em volume final de $25 \mu \mathrm{L}$ completados com água. O DNA foi então separado mediante eletroforese em gel de agarose a $0,8 \%(\mathrm{~m} / \mathrm{v})$ em TAE acrescido de brometo de etídeo $\left(0,5 \mu \mathrm{g} \mathrm{mL}^{-1}\right)$. As bandas correspondentes aos fragmentos de DNA foram visualizadas com auxílio de lâmpada de ultravioleta e excisadas do gel. O DNA presente nestes fragmentos de gel de agarose foram extraídos de acordo com protocolo em Anexo C (kit "Concert" - Gibco BRL).

Os genes amplificados através da PCR e clivados com NdeI e HindIII foram utilizados para clonagem no plasmídio pET20b(+) também digerido com as mesmas enzimas. Foi mantida uma proporção de DNA 10 vezes maior para o inserto em relação ao plasmídio, verificada visualmente em gel de agarose $0,8 \%$ corado com brometo de etídeo. Ambos fragmentos foram ligados como segue:

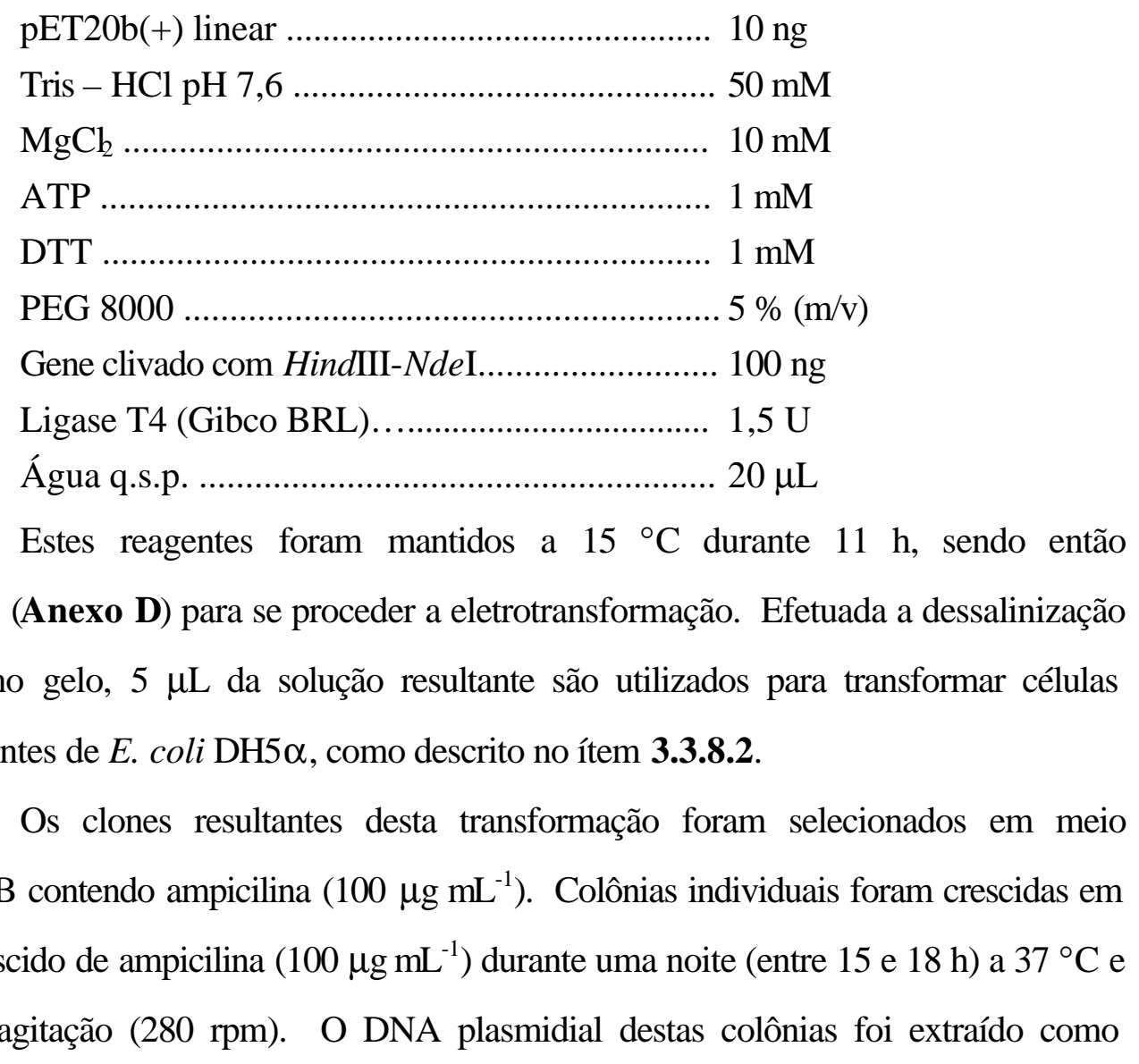


descrito no Anexo A, e analisado mediante perfil eletroforético após digestão com enzimas de restrição.

\subsubsection{Construção de plasmídios para expressão de proteínas recombinantes com cauda hexahistidina na extremidade carboxila terminal}

Os genes Xf - 1267 e Xf - 2708 de X. fastidiosa foram amplificados de

acordo com o ítem 3.3.2. Com exceção dos iniciadores que foram utilizados em concentração final de 0,5 pmoles e os dNTPs a $100 \mu \mathrm{M}$, as outras condições foram idênticas àquelas descritas em 3.3.2. Estes genes foram utilizados para clonagem no plasmídio pET20b(+).

Nestas construções foi alterado o códon de finalização do gene, na posição coincidente com a criação do sítio para a enzima de restrição HindIII. Desta forma, a tradução é mantida após o término da leitura do último códon que compõem a estrutura original do gene. A continuação da tradução resulta na incorporação da cauda de seis histidinas, cujos códons estão inseridos "in frame" na sequiência do plasmídio pET20b(+). Assim, é produzida uma proteína recombinante que apresenta além dos aminoácidos originais, a cauda de seis histidinas na extremidade C-terminal, para efetuar a purificação através de cromatografia de afinidade (item 3.5.3.1).

Os genes amplificados através da PCR e após precipitação para limpeza (item 3.3.2) foram dissolvidos em Tris- $\mathrm{HCl} \mathrm{pH} 8,05 \mathrm{mM}$. O gene $\mathrm{Xf}-2708$ foi digerido com $3 \mathrm{U}$ de NdeI e 3 U de HindIII, simultaneaemnte, em tampão Tris- $\mathrm{HCl}$ pH 8,0 50 mM, MgCl 10 $\mathrm{mM}$ e $\mathrm{NaCl} 50 \mathrm{mM}$ durante $5 \mathrm{~h}$ a $37^{\circ} \mathrm{C}$ em volume final de $15 \mu \mathrm{L}$ completados com água. O DNA foi então separado mediante eletroforese em gel de agarose a 0,8 \% (m/v) em TAE acrescido de brometo de etídeo $\left(0,5 \mu \mathrm{g} \mathrm{mL}^{-1}\right)$. A banda correspondente ao fragmento de DNA foi visualizada com auxílio de lâmpada de ultravioleta e excisado do gel. O DNA presente neste fragmento de gel de agarose foi extraído de acordo com protocolo em Anexo C. O gene Xf - 1267 foi digerido da mesma forma, com duas adições das enzimas, 
intercaladas por uma limpeza como descrito no Anexo B. Assim, este gene foi digeridos com 7 U de cada enzima de restrição.

Os genes amplificados através da PCR e clivados com NdeI e HindIII foram utilizados para clonagem no plasmídio pET20b(+), também digerido com as mesmas enzimas. Foi mantida uma proporção de DNA 10 vezes maior para o inserto em relação ao plasmídio, verificada visualmente em gel de agarose $0,8 \%$ corado com brometo de etídeo.

Ambos fragmentos foram ligados como segue:

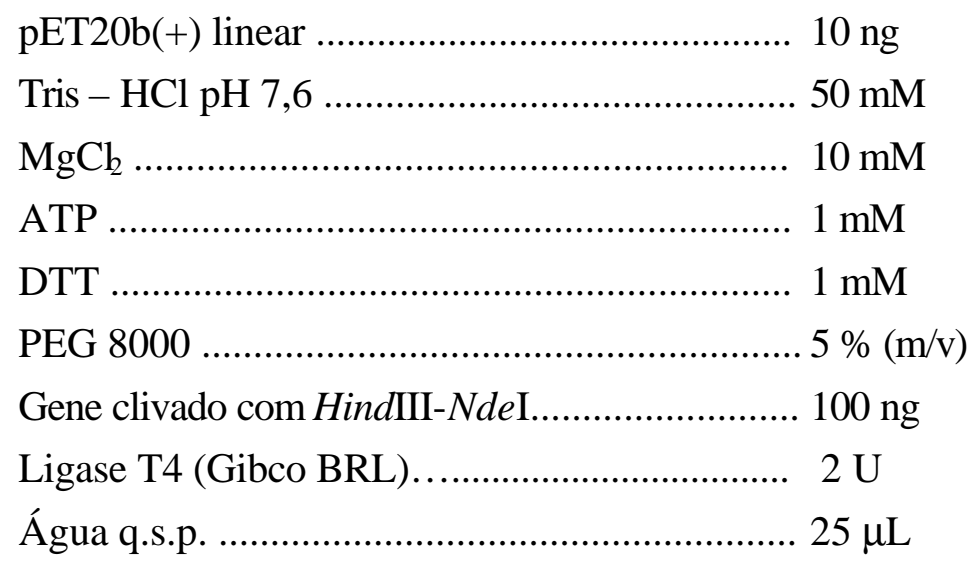

Estes reagentes foram mantidos a $16{ }^{\circ} \mathrm{C}$ durante $12 \mathrm{~h}$, sendo então dessalinizados (Anexo D) para proceder a eletrotransformação. Foram utilizados $2 \mu \mathrm{L}$ de cada reação de ligação para a tranformação, efetuada como descrita no item 3.3.8.2. Alíquotas do meio de cultura contendo as células de E. coli DH5 $\alpha$ submetidas à transformação, foram espalhadas em meio LB sólido contendo ampicilina (100 $\left.\mu \mathrm{g} \mathrm{mL}^{-1}\right) \mathrm{em}$ placas de petri plásticas. Este meio foi mantido a $37^{\circ} \mathrm{C}$ durante $18 \mathrm{~h}$, sendo então avaliado o crescimento de colônias dos possíveis transformantes contendo o gene de interesse inserido no plasmídio pET20b(+).

Colônias individuais foram crescidas em meio LB acrescido de ampicilina (100 $\mu \mathrm{g} \mathrm{mL}^{-1}$ ) foram analisadas como descrito em 3.3.3. Clones que apresentaram o inserto de tamanho correspondente ao gene clonado foram armazenados com glicerol em ultracongelador $\mathrm{a}-80{ }^{\circ} \mathrm{C}$. A confirmação final foi efetuada através de seqüenciamento, como descrito em 3.3.6. 


\subsubsection{Clonagem dos genes Xf-810 e Xf-818 no plasmídio de expressão pET28b}

Os genes Xf -810 , Xf - 818 clonados em pET20b(+) (item 3.3.4) foram subclonados em pET28b(+) utilizando os mesmo sítios de restrição previamente utilizados: NdeI e HindIII. A partir desta subclonagem, os respectivos genes produzem proteínas recombinantes com a incorporação da cauda hexahistidina na extremidade $\mathrm{N}$-terminal da proteína (Figura 6). Esta conformação advém do fato da estrutura do plasmídio pET28b(+) ser diferente do pET20b(+). Genes clonados no sítio de restrição NdeI são inseridos a jusante da região iniciadora. Assim, a transcrição inicia-se dentro da sequiência do plasmídio continuando a leitura "in frame" através do gene clonado. Antes de atingir o ponto respectivo ao sítio de NdeI (ATG inicial do gene), há a tradução da cauda de histidina. Como o códon de finalização original está mantido no gene clonado, este é o responsável pelo fim da tradução. Como resultado, temos o His tag N-terminal na proteína recombinante, o qual é utilizado para se efetuar a purificação através de cromatografia de afinidade (item 3.5.3.1).

Os genes Xf -810 e Xf -818 , clonados no plasmídio pET20b(+), denominados pNAW1 e pNAW3, respectivamente (item 3.3.4) foram clivados e utilizados para clonagem no plasmídio de expressão pET28b(+).

Cinco microgramas do plasmídio de expressão pET28b(+) foram digeridos com $5 \mathrm{U}$ de HindIII e $5 \mathrm{U}$ de NdeI em Tris- $\mathrm{HCl} 50 \mathrm{mM} \mathrm{pH} 8, \mathrm{MgCl} 10 \mathrm{mM}$ e $\mathrm{NaCl} 50$ $\mathrm{mM}$, durante $2 \mathrm{~h}$ a $37{ }^{\circ} \mathrm{C}$. Dois microgramas dos plasmídios pNAW1 e pNAW3 foram clivados da mesma maneira. Os produtos destas clivagens foram submetidos a eletroforese em gel de agarose $0,8 \%(\mathrm{~m} / \mathrm{v})$ em TAE acrescido de brometo de etídeo $\left(0,5 \mu \mathrm{g} \mathrm{mL}^{-1}\right)$. As bandas correspondentes aos genes Xf -810 e Xf - 818 foram visualizadas com o auxílio de lâmpada de ultravioleta e excisadas do gel. O DNA presente nestes fragmentos de gel de agarose foi extraído de acordo com protocolo em Anexo C. 

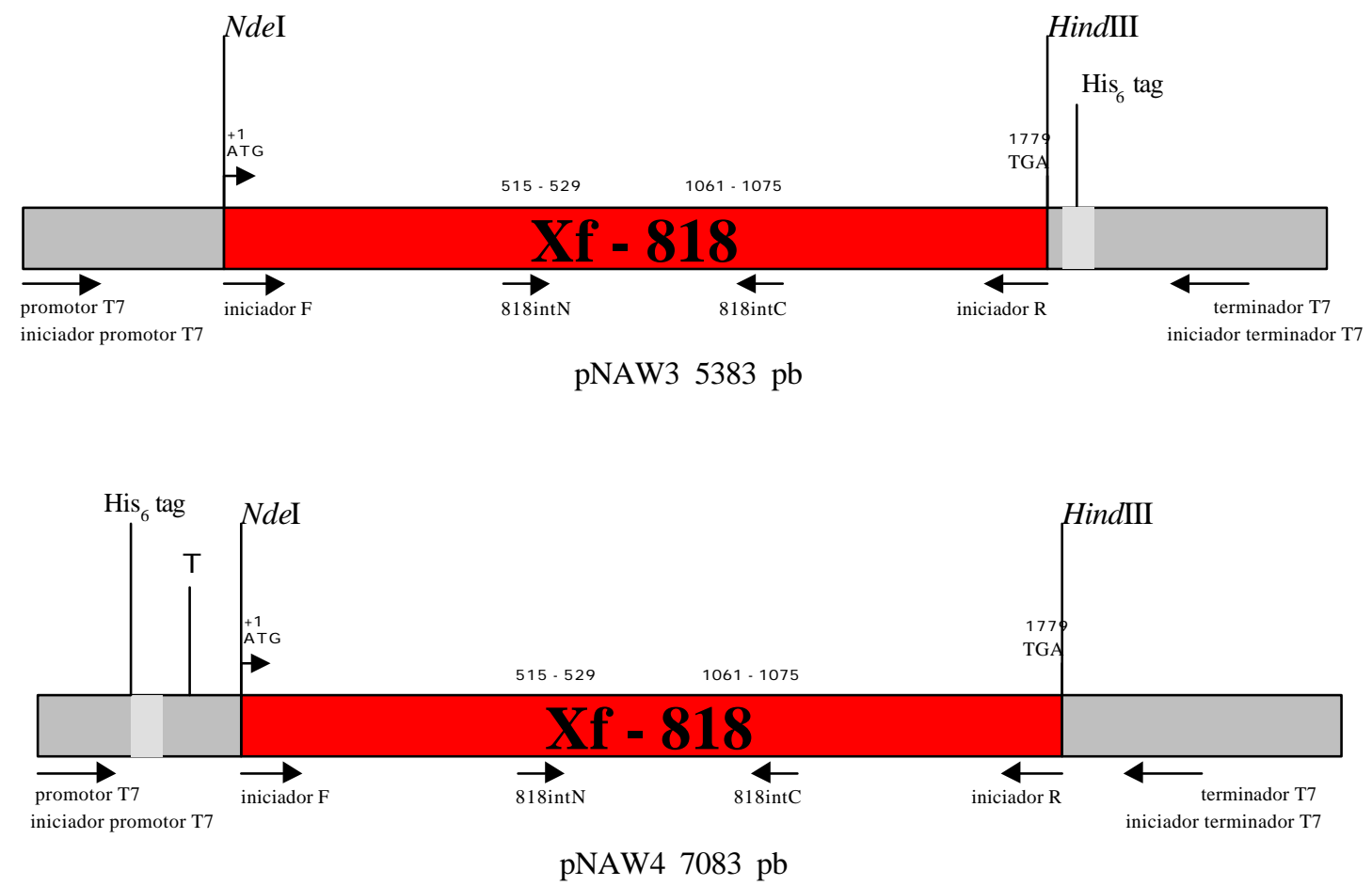

Figura 6 - Localização da região complementar dos iniciadores utilizados para a clonagem e seqüenciamento completo dos genes clonados em pET20b ou pET28b e das regiões flanqueadoras, incluindo a seqüência que produz o His ${ }_{6}$ tag. Estão exemplificados os iniciadores empregados para a clonagem/seqüenciamento do gene Xf - 818 em pET20b (plasmídio pNAW3) e pET28b (plasmídio pNAW4). Estão também indicados os sítios de restrição NdeI e HindIII. Iniciadores F e R são os indicados na Tabela 6. 
Foi mantida uma proporção de DNA 10 vezes maior do inserto em relação ao plasmídio, verificada visualmente em gel de agarose $0,8 \%$ corado com brometo de etídeo. Ambos fragmentos foram ligados como segue:

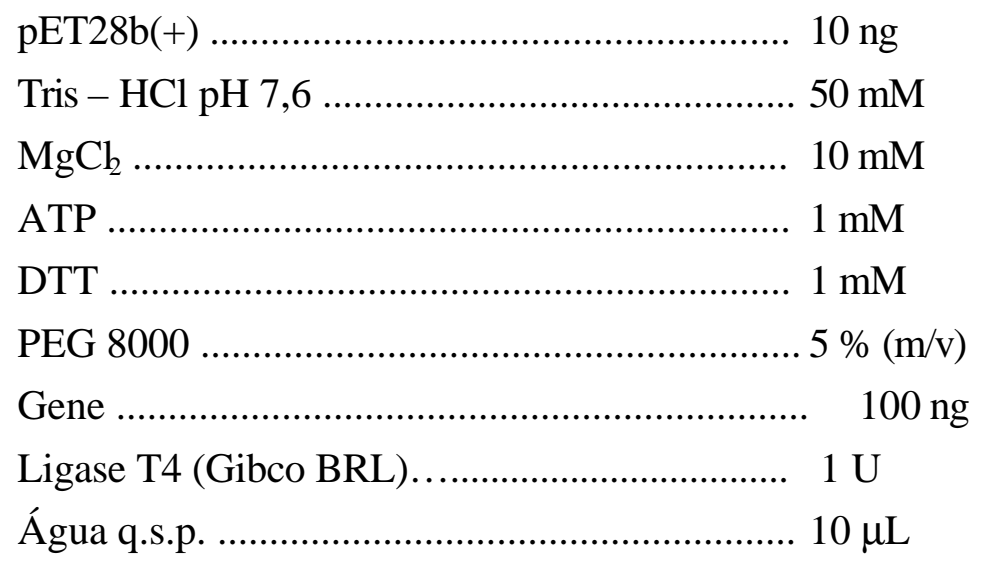

Estes reagentes foram mantidos a $16{ }^{\circ} \mathrm{C}$ durante $15 \mathrm{~h}$, sendo então dessalinizados (Anexo D) para proceder a eletrotransformação, como descrita no ítem 3.3.8.2.

Alíquotas do meio de cultura contendo as células de E. coli $\mathrm{DH} 5 \alpha$ que foram submetidas a transformação foram espalhadas em meio LB sólido contendo canamicina (50 $\mu \mathrm{g}$ $\mathrm{mL}^{-1}$ ) em placas de petri plásticas. Este meio foi mantido a $37{ }^{\circ} \mathrm{C}$ durante $18 \mathrm{~h}$, sendo então avaliado o crescimento de colônias dos possíveis transformantes contendo o gene de interesse inserido no plasmídio $\mathrm{pET} 28 \mathrm{~b}(+)$.

Colônias individuais foram crescidas em meio LB acrescido de canamicina (50 $\mu \mathrm{g} \mathrm{mL}^{-1}$ ) durante uma noite (entre 15 e $18 \mathrm{~h}$ ) a $37^{\circ} \mathrm{C}$ e $280 \mathrm{rpm}$. O DNA plasmidial destas colônias foi extraído como descrito no Anexo A, e analisado mediante digestão com enzimas de restrição HindIII - XbaI para observação da presença do inserto no plasmídio. Ademais, o DNA plasmidial destes clones selecionados foi amplificado através da PCR, utilizando-se os iniciadores promotor T7 e terminador T7, de acordo com as condições descritas em 3.3.2. Clones que apresentaram o inserto de tamanho correspondente ao gene clonado foram 
armazenados com glicerol em ultracongelador a $-80{ }^{\circ} \mathrm{C}$. A confirmação final foi efetuada através de seqüenciamento, como descrito em 3.3.6.

\subsubsection{Seqüenciamento dos genes clonados nos vetores de expressão}

A extração do DNA plasmidial foi efetuada como descrita no protocolo Anexo A. O DNA foi quantificado em gel de agarose $0,8 \%(\mathrm{~m} / \mathrm{v})$ após eletroforese em TAE. As reações de amplificação para seqüenciamento foram efetuadas em placas microtítulo de 96 poços, sendo $200 \mu \mathrm{L} /$ poço. Nas reações de amplificação para seqüenciamento foram utilizados os iniciadores promotor $\mathrm{T} 7$ (seqüenciamento da extremidade 5 ' do gene) e terminador T7 (seqüenciamento da extremidade 3' do gene). Também foram empregados os iniciadores originais utilizados na amplificação de cada gene para a clonagem e os iniciadores que anelam na porção interna dos genes (Tabela 6 e 7). Na Figura 6 observa-se o esquema de como estes iniciadores anelam-se no plasmídio e no gene a ser amplificado.

Cada reação consistiu de 10 pmoles do iniciador (10 pmoles $\left.\mu \mathrm{L}^{-1}\right), 2 \mu \mathrm{L}$ de tampão (Tris- $\mathrm{HCl} 200 \mathrm{mM}$ pH 9, $\mathrm{MgCh}_{2} 5 \mathrm{mM}$ ), $100 \mathrm{ng}$ de DNA plasmidial $\left(100 \mathrm{ng} \mu \mathrm{L}^{-1}\right)$ e $2 \mu \mathrm{L}$ dos reagentes de seqüenciamento (kit BigDye ${ }^{\mathrm{TM}}$ Terminator - Perkin Elmer Biosystems). O volume final foi de $10 \mu \mathrm{L}$ completado com água ultrapura esterilizada. Os reagentes foram misturados com a pipeta, centrifugados $30 \mathrm{~s}$ para reunir os regentes no fundo do poço. A placa foi coberta com uma malha de borracha e efetuou-se a amplificação em termociclador (Modelo PTC-100; MJ Research), conforme protocolo:

$\left.\begin{array}{lc}96{ }^{\circ} \mathrm{C} & 180 \mathrm{~s} \\ 94{ }^{\circ} \mathrm{C} & 45 \mathrm{~s} \\ 60^{\circ} \mathrm{C} & 270 \mathrm{~s} \\ 60^{\circ} \mathrm{C} & 2 \mathrm{~min} \\ 4{ }^{\circ} \mathrm{C} & \infty\end{array}\right\} \quad 35$ ciclos

Foi efetuada a purificação do produto de PCR de seqüenciamento conforme protocolo em Anexo E. Após purificação e secagem do DNA, foram adicionados $10 \mu \mathrm{L}$ de 
formamida a cada reação de amplificação da PCR de seqüenciamento. As placas foram agitadas durante $30 \mathrm{~s}$, o DNA foi desnaturado durante $5 \mathrm{~min}$ a $95{ }^{\circ} \mathrm{C}$ e as placas foram depositadas no gelo. Os plasmídios dos clones selecionados através de análise de restrição e PCR foram seqüienciados em sequenciador capilar automático ABI-3100 (Applied Biosystems/Hitachi). Este seqüenciador utiliza 16 capilares de $50 \mathrm{~cm}$ de comprimento, preenchidos com a resina 3100 POP6. O tempo de corrida foi de 2,5 h. Nos demais parâmetros, o seqüenciamento foi realizado de acordo com as instruções do fabricante (Applied Biosystems, Foster City, CA USA).

\subsubsection{Análise dos plasmídios seqüenciados}

Os programas de coleta e análise dos dados gerados pelo seqüenciador fornecem dois tipos de dados. Um arquivo contendo a sequiência na forma textual é gerado, além de outro arquivo contendo o cromatograma ou eletroferograma, o qual possui dados qualitativos da sequiência que foi gerada.

Para cada plasmídio a ser seqüenciado foram efetuadas no mínimo três reações de amplificação com cada iniciador (Tabelas 6 e 7). As seqüências geradas desta maneira necessitam ser ordenadas para formarem um conjunto de seqüências que cobre todo o fragmento clonado, assim como as seqüências onde foram inseridos os sítios de restrição para clonagem e as extremidades do plasmído de expressão. Dessa maneira, todos os "reads" ou seqüências derivadas do seqüenciamento de um mesmo plasmídio foram analisadas conjuntamente. A análise do alinhamento e a montagem de uma sequiência consenso ou contig para estes "reads" de um mesmo plasmídio foram efetuadas no conjunto de programas Phred

+ Phrap + Consed (Gordon et al., 1998). O algoritmo Phred analisa a qualidade do cromatograma, ou seja, da sequiência obtida a partir do seqüenciador. A seguir, o algoritmo Phrap faz a montagem das seqüências, criando os contigs pelo alinhamento das regiões sobrepostas nas diferentes sequiências. A visualização dos dados gerados pelo Phrad é efetuada pelo algoritmo Consed, onde pode-se verificar a qualidade de cada base e a 
visualização de todo o "contig", das sequiências que o compõem e da sequiência consenso. Neste mesmo aplicativo pode-se visualizar as possíveis ORFs em todas as "frames" possíveis.

Os contigs derivados destes "reads" foram comparados diretamente com a sequiência do gene clonado neste plasmídio, utilizando o algoritmo "Blast two sequences" (Tatusova e Madden, 1999). De posse desta sequiência foi efetuada a construção dos mapas dos plasmídios utilizados neste trabalho (Tabela 4). O objetivo principal deste seqënciamento foi o de verificar se houve a incorporação errônea de nucleotídeos durante a amplificação através da PCR. O seqüenciamento completo dos genes clonados também permitiu verificar a correta clonagem do fragmento e verificar se o quadro de leitura estava na seqüência correta.

\subsubsection{Transferência dos plasmídios para $E$. coli DH5 $\alpha$, BL21 aDE3) ou BL21 (גDE3)pLysS}

Todas as etapas de manipulação das colônias bacterianas foram conduzidas sob condição asséptica em capela de fluxo laminar.

Células das linhagens de E. coli DH5 $\alpha$, BL21 ( $\lambda$ DE3) ou BL21 ( $\lambda$ DE3)pLysS (Novagen, Darmstadt - Alemanha) (Tabela 3) foram prepararadas para transformação de acordo com protocolo em Anexo F (Sambrock, Fritisch \& Maniatis, 1989).

\subsubsection{Transformação de células de $E$. coli}

A eletroporação de células bacterianas fornece uma maneira rápida e muito eficiente de transformá-las. Entretanto, cuidados devem ser tomados para o sucesso desta etapa. Deve-se sempre manter a temperatura próxima a zero, mantendo a cubeta no gelo para se evitar o aumento da temperatura nas células no momento da aplicação da corrente elétrica. O meio no qual será efetuada a transformação não pode apresentar concentração elevada de sais, caso contrário, as células imersas em líquido poderão estourar. Assim, é necessário a retirada do excesso de sais da reação de ligação antes da eletrotransformação. Um protocolo barato e eficiente está descrito no Anexo D. 
Cinquienta microlitros de células eletrocompetentes, produzidas no momento de uso ou estocadas em ultracongelador $\left(-80^{\circ} \mathrm{C}\right)$, foram mantidas durante pelo menos 10 min no gelo. A reação de ligação foi misturada às células com auxílio de ponteira, sendo então transferidas para uma cubeta de eletroporador estéril e mantida no gelo (Cubetas GenePulser ${ }^{\circledR}$ com espaço entre os eletrodos de 0,1 cm; Bio-Rad 165-2089). Após 1 min no gelo, foi efetuada a eletroporação em equipamento GenePulser (Bio-Rad, California - USA) a 1,8 kV, $200 \Omega$ para gerar um pulso de aproximadamente $5 \mathrm{~ms}$. A eletroporação é efetuada a baixas temperaturas, pois a eficiência da transformação diminui até 100 vezes quando efetuada a temperatura ambiente (Sambrock, Fritisch \& Maniatis, 1989).

Imediatamente após a aplicação da corrente elétrica foram adicionados 0,95 $\mathrm{mL}$ de meio $\mathrm{LB}$ e as células foram mantidas a $37{ }^{\circ} \mathrm{C}$ durante $1 \mathrm{~h}$ a $180 \mathrm{rpm}$. Após este período, alíquotas foram plaqueadas em meio LB sólido contendo antibiótico apropriado. As placas foram incubadas a $37{ }^{\circ} \mathrm{C}$ durante uma noite $(15$ a 18 h) e as colônias que cresceram representam os possíveis clones resultantes de cada reação de ligação. Esta colônias individuais foram crescidas em meio LB líquido suplementado com antibiótico apropriado.

Os plasmídios pNAW1, pNAW3, pNAW5 (construídos conforme 3.3.4), pNAW2, pNAW4, pNAW6 e pNAW13 (construídos conforme 3.3.5) foram transformados em E. coli BL21(DE3)/ BL21(DE3) pLysS, utilizando-se cerca de 5 ng de cada plasmídio. A seleção dos transformantes foi efetuada em meio sólido LB/ampicilina para os clones da série pET20b(+) e em meio sólido LB/canamicina para os clones da série pET28b(+). No caso da linhagem BL21(DE3) pLysS, o meio seletivo continha também o antibiótico cloranfenicol a 25 $\mu \mathrm{g} \mathrm{mL} \mathrm{L}^{-1}$.

As colônias resultantes e que expressaram as proteínas dos genes em questão foram analisadas de acordo com o item 3.4. Estas colônias foram nomeadas com o nome do respectivo plasmídio e armazenadas em glicerol em ultracongelador. 


\subsection{Expressão heteróloga das celulases nos plasmídios pET20b e pET28b}

A linhagem lisogênica BL21( $\lambda$ DE3) contém uma cópia cromosomal única do gene para a polimerase do RNA T7 (gene 1 do fago T7), sob o controle do promotor induzível lacUV5 (Studier \& Moffatt, 1986). A adição de lactose ou IPTG induz o promotor lacUV5 a produzir a polimerase do RNA T7, a qual por sua vez inicia a elevada expressão do gene sob o controle do promotor T7 (promotor $\phi 10$ do fago T7). A expressão basal do gene sob o controle do promotor T7 pode ser controlada pela presença de lisozima T7 bacteriófaga, um inibidor natural da polimerase do RNA T7. Esta lisozima pode ser produzida em baixa escala pelo plasmídio pLysS (Figura 5). Este plasmídio possui o gene 3.5 do fago T7, para a lisozima T7 e confere resistência a cloranfenicol. O S de pLysS denota a orientação oposta ao promotor tet do plasmídio parental pACYC184 (Studier, 1991). pLysS é compatível com os vetores pET para expressão a partir do promotor $\mathrm{T} 7$, sendo suficiente para estabilizar o plasmídio alvo (Studier, 1991). Assim, genes cujo produto seja tóxico à célula bacteriana podem ser expressos de maneira finamente controlada, permitindo porém altos níveis de expressão da proteína alvo após indução (Studier, 1991). Adicionalmente, a presença desta lisozima facilita a preparação de extratos celulares para a purificação da proteína-alvo, pois sob condições apropriadas auxilia a lisar a célula bacteriana (Studier, 1991).

\subsubsection{Otimização da expressão das proteínas he terólogas em E. coli}

Clones de E. coli BL21(DE3), contendo os plasmídios pNAW1, pNAW3 e pNAW5 ou clones de E. coli BL21(DE3)pLysS contendo os plasmídios pNAW2, pNAW4 e pNAW6, foram utilizados nos ensaios a seguir. Os plasmídios utilizados foram transformados em linhagens de E. coli acima descritas através de eletrotransformação (item 3.3.8.2). Das colônias resultantes desta transformação, crescidas em meio sólido com antibiótico, foram escolhidas aleatoriamente de cinco a sete colônias para serem avaliadas. Estas colônias foram avaliadas em ensaio para celulase em placa (3.4.1.1), em ensaio espectrofotométrico (3.4.1.2) e também através de eletroforese (itens 3.4.1.3 e 3.4.1.4). Nos ensaios abaixo descritos, foi utilizado meio LB com ampicilina $\left(100 \mu \mathrm{g} \mathrm{m}^{-1}\right)$ para clones derivados do pET20b(+) e LB 
com canamicina $\left(50 \mu \mathrm{g} \mathrm{mL}^{-1}\right)$ para os derivados de $\mathrm{pET} 28 \mathrm{~b}(+)$.

Os clones selecionados (um clone para cada plasmídio) foram utilizados nos ensaios subseqüentes, onde objetivamos determinar o melhor tempo de expressão após indução com IPTG $(0,4 \mathrm{mM})$ e a melhor temperatura de cultivo após o período de indução para a expressão da proteína-alvo (ítem 3.4.1.2). Estes mesmos clones foram utilizados nos ensaios do item $\mathbf{3 . 5}$.

A produção de celulases foi avaliada sob duas formas, em placa de petri e em ensaio espectrofométrico indireto. Utilizamos o substrato solúvel celulose carboximetilada, como descrito abaixo.

\subsubsection{Ensaio para endoglicanases em placa de petri}

A evidência da formação de complexos entre corantes tais como o vermelho de congo e polissacarídeos tem sido avaliada através de alterações na viscosidade ou solubilidade dos polissacarídeos e em alterações nas propriedades espectrais do corante. Desde que a formação destes complexos acontece somente com o polímero, as alterações associadas à ligação do corante podem ser utilizadas para monitorar a atividade enzimática hidrolítica (Wood et al., 1988). A difusão radial de uma enzima num gel contendo substrato permite a determinação da atividade hidrolítica, desde que a distinção entre substrato e produto seja possível. O diâmetro da zona de difusão é proporcional ao logaritmo da concentração da enzima (Wood et al., 1988). Este ensaio tem sido utilizado para a avaliação de microrganismos celulolíticos e suas enzimas (Teather \& Wood, 1982). O mesmo princípio, aplicado após eletroforese em gel de poliacrilamida está descrito no item 3.4.1.4.

A celulose carboximetilada (CMC) é utilizada ao invés da celulose nativa como substrato devido à grande vantagem de sua solubilidade em água. Assim, as enzimas que agem sobre este polímero são conhecidas como celulases ou $\beta$-1,4-endoglicanases, embora a atividade também seja descrita como carboximetilcelulases (CMCase).

O ensaio em placa foi conduzido da seguinte maneira. Os clones BL21(DE3)/pNAW1, pNAW3 e pNAW5 a serem avaliados foram crescidos durante $8 \mathrm{~h}$ em 
meio LB líquido. O meio de cultura foi retirado após centrifugação (1 min a $9300 \mathrm{~g}$ ) e novo meio LB contendo o indutor IPTG (isopropil tiogalactosídeo) na concentração de $0,4 \mathrm{mM}$ foi adicionado às células. Os clones bacterianos foram crescidos por mais 2 horas a $37{ }^{\circ} \mathrm{C}$ e então uma gota desta suspensão bacteriana foi depositada sobre o meio LB solidificado com ágar $1,5 \%(\mathrm{~m} / \mathrm{v})$ e contendo CMC $0,1 \%(\mathrm{~m} / \mathrm{v})$ em placa de petri. Após o crescimento adequado da colônia neste meio (entre 12 e $36 \mathrm{~h}$ a $37^{\circ} \mathrm{C}$ ), foi avaliada a atividade de celulase. As colônias bacterianas foram retiradas do meio com água e descartadas com hipoclorito de sódio $2 \%$. O meio LB/CMC foi coberto com vermelho congo 0,1\% durante $30 \mathrm{~min}$ e em seguida lavado com água destilada. Foram feitas então duas lavagens com $\mathrm{NaCl} 1 \mathrm{M}$, de 15 min cada. (Meletzus et al., 1993; Teather \& Wood, 1982). Deste modo, a atividade endoglicolítica é revelada pela formação de zonas amarelas em fundo vermelho (Park et al., 1998; Shen et al., 1995).

\subsubsection{Ensaio espectrofométrico indireto para endoglicanases}

A atividade endoglicolítica, também denominada de celulase ou carboximetil celulase (CMCase), é efetuada com o substrato hidrosolúvel CMC. A clivagem do substrato polimérico origina novas cadeias de sacarídeos com extremidades redutoras. Desta maneira, um maior número de extremidades redutores denota maior atividade hidrolítica da enzima.

A reação consiste do substrato CMC dissolvido em tampão apropriado. A menos que de outra maneira descrito, os ensaios para avaliação de celulase foram efetuados com CMC a $1 \%$ dissolvido em tampão acetato de sódio $50 \mathrm{mM} \mathrm{pH} \mathrm{5,2.} \mathrm{O} \mathrm{substrato} \mathrm{e} \mathrm{a}$ enzima são então incubados a temperatura apropriada, por exemplo $40^{\circ} \mathrm{C}$, durante um tempo estabelecido. Após este período, uma alíquota é utilizada para determinar quanto açúcar redutor foi liberado, através do método de Lever (1972). O controle desta reação consiste dos mesmos reagentes sem incubação prévia. Este controle tem por objetivo quantificar os açúcares redutores presentes no substrato não clivado enzimaticamente e na amostra, para que possam ser subtraídos dos oriundos da atividade enzimática. Assim obtemos a quantidade de açúcares redutores liberados, por unidade de tempo e por quantidade de proteína presente na 
amostra testada. A temperatura e o tempo de incubação foram variáveis depentes do tipo de ensaio empregado, assim estas variáveis serão descritas apropriadamente em cada ensaio. Quando necessário armazenar os substratos, foi adicionado azida sódica a 0,05 \% (concentração final, $\mathrm{m} / \mathrm{v}$ ) e o substrato foi armazenado a $4{ }^{\circ} \mathrm{C}$.

A quantificação de açúcares redutores pode ser avaliada com a hidrazido do ácido $p$-hidroxibenzóico. A hidrazida é dissolvida a $5 \%$ (m/v) em $\mathrm{HCl}$ 0,5 M e então diluída a $1 \%$ (v/v) em NaOH 0,5 M. Esta solução de hidrazida é misturada com a solução a ser quantificada na proporção de 3:1 (v/v). As soluções são misturadas e fervidas em banho-maria durante $5 \mathrm{~min}$. Após serem resfriadas a temperatura ambiente, a absorbância a $410 \mathrm{~nm}\left(\mathrm{~A}_{410}\right)$ é avaliada em espectrofotômetro (Lever, 1972). O valor obtido é plotado em curva-padrão estabelecida com quantidades conhecidas de um açúcar-padrão como a glicose, submetidas às mesmas condições. Assim, pode-se quantificar os açúcares redutores presentes na amostra (Apêndice 1). Este método não deve ser utilizado para a quantificação de açúcares totais da amostra.

Clones de E. coli BL21(DE3), com os plasmídios pNAW1, pNAW3 e pNAW5, foram crescidos durante $8 \mathrm{~h} \mathrm{em} 3 \mathrm{~mL}$ de meio LB. O meio de cultura foi retirado após centrifugação (1 min a $9300 \mathrm{~g}$ ) e novo meio LB contendo o indutor IPTG (isopropil tiogalactosídeo) na concentração de $0,4 \mathrm{mM}$ foi adicionado às células. A cultura foi mantida a $37{ }^{\circ} \mathrm{C}$ por 4 a $6 \mathrm{~h}$. Uma alíquota de $1,5 \mathrm{~mL}$ da suspensão bacteriana foi transferida para um microtubo, centrifugada a $9300 \mathrm{~g}$ por 1 min e o sobrenadante foi utilizado para a detecção da atividade endoglicolítica em ensaio espectrofotométrico indireto.

Nesta avaliação, o meio de cultura contendo a enzima expressa heterologamente é incubada juntamente com o substrato CMC $1 \%$ em tampão acetato de sódio - ácido acético $50 \mathrm{mM}$ pH 5,2. Após $2 \mathrm{~h}$ a $40{ }^{\circ} \mathrm{C}$, a amostra é resfriada em banho de gelo e a liberação de carboidratos redutores a partir do polímero é avaliada com o método de Lever (1972). 


\subsubsection{Análise através de eletroforese desnaturante (SDS - PAGE)}

Os clones de E. coli, submetidos à avaliação em 3.4.1.2, foram analisados segundo o seu perfil de proteínas separadas através de eletroforese em gel de poliacrilamida (16 x $16 \mathrm{~cm}$ ) desnaturante descontínuo (Laemmli, 1970) (Anexo G). O gel separador foi preparado nas concentrações de $10,12,5$ ou $15 \%$ T. O gel concentrador foi preparado a 4 ou $4,5 \% \mathrm{~T}$. A eletroforese foi conduzida a $4{ }^{\circ} \mathrm{C}$.

Uma alíquota de $1 \mathrm{~mL}$ da cultura induzida dos clones que foram preparados no item 3.4.1.2 foi centrifugada ( $9300 \mathrm{~g}, 1 \mathrm{~min}$ ) e ao pelete foram adicionados $100 \mu \mathrm{L}$ de tampão da amostra desnaturante (Anexo G). Esta amostra foi congelada até sua utilização. Antes da eletroforese, a amostra foi fervida em banho-maria durante 5 min, resfriada e $20 \mu \mathrm{L}$ de cada amostra foram aplicados por canaleta. Foi aplicada voltagem inicial de $100 \mathrm{~V}$ durante $1 \mathrm{~h}$, sendo então deixado durante a noite (aproximadamente 12 h a $200 \mathrm{~V}$ ou 17 h a 150 V). Após a eletroforese, os géis de poliacrilamida foram fixados e corados com azul de coomassie R-250 (Anexo H). Após descoloração foi possível observar o padrão de proteínas separadas através da eletroforese, incluindo na maioria dos casos, as proteínas expressas heterologamente.

\subsubsection{Análise através de zimograma para celulase (CMC-SDS-PAGE)}

Diferentemente do gel SDS-PAGE, este gel possui em sua composição, CMC a $0,1 \%(\mathrm{~m} / \mathrm{v})$ adicionado ao gel separador. Ademais, todas as etapas de confecção dos géis e eletroforese são idênticas às descritas no item 3.4.1.3, sendo esta técnica descrita com CMCSDS-PAGE (Park et al., 1998).

Após a eletroforese, o gel é retirado da forma, lavado em água destilada e processado para revelação da atividade endoglicolítica. Primeiramente é efetuada a renaturação em tampão Tris-HCl 10 mM pH 7,5 e Trixon X-100 a $1 \%$. Nesta etapa, devese trocar o tampão ao menos três vezes, com período de $2 \mathrm{~h}$ entre as trocas. Em seguida é efetuada a incubação a $40{ }^{\circ} \mathrm{C}$ em tampão Tris- $\mathrm{HCl} 10 \mathrm{mM} \mathrm{pH} \mathrm{7,1} \mathrm{durante} 8$ a 12 h. O tampão é substituído por vermelho congo $0,5 \%(\mathrm{~m} / \mathrm{v})$ e após $15 \mathrm{~min}$ o gel é descorado com 
$\mathrm{NaCl} 1 \mathrm{M}$ com três lavagens de 15 min cada. Nesta etapa, ocorre a revelação das bandas com atividade de endoglicanase. A atividade de CMCase é revelada pelo surgimento de áreas amareladas contra um contraste vermelho nos locais onde não houve degradação da CMC. Para aumentar o contraste, o gel é imerso em $\mathrm{HCl}$ 0,1 M, onde as áreas de atividade ficam incolores contra o contraste azul formado pela área com CMC não degradada. Deve-se utilizar um volume de aproximadamente $250 \mathrm{~mL}$ para cada gel, de forma a cobri-lo completamente. As trocas de soluções são intercaladas por banhos em água destilada (Park et al., 1998).

\subsubsection{Tempo e temperatura de indução após a adição do indutor IPTG}

A cinética de acumulação das proteínas heterólogas está sujeita a variados fatores, incluindo o tamanho e estrutra da proteína, a sua solubilidade, transporte e estabilidade. Como o objetivo do sistema de expressão proposto era o de produzir quantidades suficientes de proteína para ensaios enzimáticos, pudemos otimizar alguns fatores que interferem na sua produção. Optamos por empregar o indutor IPTG, um análogo estrutural da lactose, e que é forte indutor do sistema de expressão empregado no sistema pET (Studier \& Moffatt, 1986). Durante o transcorrer deste trabalho, IPTG foi utilizado em concentração final de 0,4 mM.

Os fatores importantes que afetam a solubilidade das proteínas expressas heterologamente e interferem conseqüentemente no seu rendimento, são a temperatura e o tempo de indução até a extração de proteínas, assim como a natureza do indutor. Muitas proteínas são mais solúveis em temperatura inferiores a $37^{\circ} \mathrm{C}$ e como E. coli pode sintetizar proteínas entre 10 e $43{ }^{\circ} \mathrm{C}$ é válido testar diversas temperaturas de indução (Ausubel et al., 1998). Assim mantivemos a temperatura de $37^{\circ} \mathrm{C}$ para o crescimento das culturas de E. coli, mas utilizamos temperaturas inferiores após a indução com IPTG.

Os clones selecionados no ítem 3.4.1.1. foram crescidos durante $12 \mathrm{~h}$ em 10 $\mathrm{mL}$ de meio LB líquido com o antibiótico apropriado. Este meio com as células foi adicionado a $300 \mathrm{~mL}$ de LB. Após 3,5 h de crescimento a $37^{\circ} \mathrm{C}$, IPTG foi adicionado na concentração 
final de 0,4 mM. Esta suspensão bacteriana com o indutor IPTG foi cultivada nas temperaturas de 28 e $32{ }^{\circ} \mathrm{C}$, e foram avaliadas no período de $0,2,4,8$ e 19 h após indução com IPTG. Nestes respectivos períodos, $1,5 \mathrm{~mL}$ do meio foi recolhido, centrifugado (9300 $\mathrm{g}, 1 \mathrm{~min}$ ) e o sobrenadante foi reservado para análise de endoglicanase (3.4.1.2) e o pelete foi utilizado para eletroforese (3.4.1.3).

\subsection{Purificação das proteínas heterólogas expressas em $E$. coli}

Nesta etapa do trabalho, utilizamos os plasmídios construídos no item 3.3 e que foram transformados em linhagens de E. coli, originando clones que foram selecionados no item 3.4 e otimizados quanto à expressão da proteína recombinante (3.4.2). A seguir, são descritos os protocolos para produção, extração e tentativas de purificação das proteínas de $X$. fastidiosa expressas heterologamente em E. coli.

\subsubsection{Produção e extração de proteínas a partir das células de $E$. coli}

Tomando por base os ensaios anteriores (item 3.4.2), os clones selecionados foram cultivados em $5 \mathrm{~mL}$ de LB (amplicilina $100 \mu \mathrm{g} \mathrm{mL}^{-1}$ ou canamicina $50 \mu \mathrm{g} \mathrm{mL}^{-1}$ ) durante $15 \mathrm{~h}$. Estes $5 \mathrm{~mL}$ de cultura foram inoculados em $300 \mathrm{~mL}$ de meio LB contendo antibiótico (amplicilina $100 \mu \mathrm{g} \mathrm{mL}^{-1}$ ou canamicina $50 \mu \mathrm{g} \mathrm{mL}^{-1}$ ). Após a inoculação, o meio de cultura foi mantido a $37{ }^{\circ} \mathrm{C}$ durante 8 h a 280 rpm. Foi então feita a indução com IPTG na concentração final de $0,4 \mathrm{mM}$ e a cultura foi mantida a partir deste período a $32{ }^{\circ} \mathrm{C}, 280 \mathrm{rpm}$ durante $12 \mathrm{~h}$.

$\mathrm{O}$ meio de cultura foi centrifugado a $5000 \mathrm{~g}$ durante $10 \mathrm{~min}$ a $4{ }^{\circ} \mathrm{C}$ e o pelete de células resultante foi lavado com Tris- $\mathrm{HCl}$ pH 7,5 20 mM, NaCl 100 mM e EDTA 1 mM. Após centrifugação a $5000 \mathrm{~g}$ durante 5 min a $4{ }^{\circ} \mathrm{C}$, o pelete foi ressuspenso em tampão Tris$\mathrm{HCl}$ pH 7,5 50 mM, NaCl 300 mM, glicerol $10 \%$ sendo adicionado PMSF a $1 \mathrm{mM}$ no momento do uso. Foi mantida a proporção de $10 \mathrm{~mL}$ de tampão para $1 \mathrm{~g}$ de pelete. Após ressuspensão do pelete com auxílio de ponteira, foi adicionado Triton X-100 na concentração final de $0,1 \%$. Estes reagentes foram misturados e submetidos a 3 ciclos de congelamento e 
descongelamento. As células bacterianas no tampão são congeladas a $-20{ }^{\circ} \mathrm{C}$ e descongeladas em banho de gelo. Após este processo foi adicionado $\mathrm{MgCl}_{2}$ na concentração final de $10 \mathrm{mM}$ e DNaseI na concentração final de $10 \mu \mathrm{g} \mathrm{mL} \mathrm{m}^{-1}$. Os reagentes foram misturados e mantidos a temperatura ambiente $\left( \pm 25^{\circ} \mathrm{C}\right)$ durante $10 \mathrm{~min}$.

Os ciclos de congelamento e descongelamento têm a finalidade de causar a ruptura da célula bacteriana, permitindo que juntamente com o choque osmótico, os conteúdos intracelulares, principalmente do espaço periplasmático, sejam liberados e solubilizados. Este processo é mais eficiente nas linhagens que contêm o plasmídio pLysS, o qual expressa a lisozima T7, a qual auxilia na lise da célula bacteriana após o congelamento/descongelamento e lise de membranas pela adição de Triton X-100 (Studier, 1991). A DNaseI auxilia a reduzir a viscosidade do lisado de células através da clivagem do DNA presente no meio (Ausubel et al., 1998).

Após 10 min em temperatura ambiente, o lisado de células foi centrifugado a 5 $000 \mathrm{~g}$ foi novamente centrifugado a $40000 \mathrm{~g}$ durante $30 \mathrm{~min}$ a $4{ }^{\circ} \mathrm{C}$.

Após esta etapa obtivemos um lisado de células de E. coli clarificado.

\subsubsection{Precipitação com sulfato de amônio}

Durante a realização dos ensaios de precipitação de proteínas, empregamos sulfato de amônio sólido, e a quantidade empregada foi calculada como segue:

$$
g=\quad \begin{aligned}
& \left.\quad \underline{533\left(S_{2}\right.}-\underline{S}_{1}\right) \\
& 100-0,3 S_{2}
\end{aligned}
$$

Onde $\mathrm{g}=$ grama de sulfato de amônio a ser adicionado a 1 litro de solução; $\mathrm{S}_{1}$ $=\%$ saturação inicial do sal e $S_{2}=\%$ saturação a ser atingida (Scopes, 1982). Diversos autores, como Scopes (1982) apresentam tabelas para calcular a quantidade de sal a ser adicionado em cada etapa do processo.

Nas tentativas de puficação dos genes Xf - 818 (expresso com $\mathrm{His}_{6}$ tag Nterminal pelo plasmídio pNAW4) e Xf - 2708 (expresso com His 6 tag C-terminal pelo 
plasmídio pNAW6), efetuamos uma precipitação fracionada com sulfato de amônio com incrementos de $20 \%$, iniciando em 20 e terminando na saturação máxima (100\%). Nosso objetivo foi o de eliminar o máximo das proteínas indesejáveis de E. coli para procedermos a purificação. Posteriormente, nas etapas de caracterização da atividade enzimática (item 3.6), empregamos precipitação em saturação a 20 e 80 \% (para as proteína Xf - 810 e Xf - 818) e 60 e $100 \%$ para Xf - 2708, objetivando somente concentrar a proteína heteróloga. A diferença de saturação justifica-se pela existência de uma relação entre massa da proteína e precipitação com sulfato de amônio.

Às preparações protéicas a serem precipitadas foi adicionado EDTA $1 \mathrm{mM}$. A quantidade apropriada de sulfato de amônio para a saturação desejada foi pesada e adicionada em pequenas quantidades à preparação proteica. Esta amostra estava sob agitação (agitador magnético) a $4{ }^{\circ} \mathrm{C}$. Após a adição do sulfato de amônio e respectiva dissolução, a solução foi mantida mais 15 min sob agitação. A solução foi então centrifugada a $20000 \mathrm{~g}$ durante 50 min a $4{ }^{\circ} \mathrm{C}$. O pelete foi dissolvido em 1 a $2 \mathrm{~mL}$ de tampão acetato de sódio pH 5,2 $50 \mathrm{mM} \mathrm{e}$ reservado. Ao sobrenadante foi adicionado sulfato de amônio na saturação deseja e todo o processo foi repetido. Após cada etapa, uma concentração de sulfato de amônio maior foi atingida, alcançando 20, 40, 60, 80 e $100 \%$ de saturação. Os peletes resultantes de cada etapa e o sobrenadante final foram dialisados (membrana de diálise com exclusão de $10 \mathrm{kDa}$ ) contra água destilada a $4{ }^{\circ} \mathrm{C}$, com no mínimo duas trocas de água de $15 \mathrm{~L}$ cada. As amostras foram concentradas no saco de diálise contra PEG 20000.

Após a diálise, as amostras foram novamente centrifugadas para retirar agregados que possam ter sido formados $\left(20000 \mathrm{~g} 10 \mathrm{~min} 4{ }^{\circ} \mathrm{C}\right)$.

Todas as amostras utilizadas e produzidas nas etapas de precipitação com sulfato de amônio foram avaliadas quanto aos teores de proteínas (Bradford, 1976) e carboidratos redutores (Lever, 1972; item 3.4.1.2) e atividade endoglicolítica sobre CMC (Shen et al., 1995). Estas amostras também foram submetidas a eletroforese em gel desnaturante (item 3.4.1.3) para observarmos o perfil eletroforético das proteínas presentes. 
Quinhentos miligramas do corante azul de coomassie G250 são diluídos em $250 \mathrm{~mL}$ de etanol $95 \%$, adicionando-se $500 \mathrm{~mL}$ de ácido fosfórico $85 \%$ (m/v). Esta solução é diluída para um volume final de $1000 \mathrm{~mL}$ e filtrada em papel filtro Whatman \# 1 . Assim, as concentrações finais serão: corante 0,05\% (m/v); etanol 23,8 \% (v/v) e ácido fosfórico 42,5 \% $(\mathrm{m} / \mathrm{v})$. Este reagente é utilizado para avaliação de amostras com até $20 \mu \mathrm{g}$ de proteínas por $\mathrm{mL}$. Mistura-se $200 \mu \mathrm{L}$ do corante com $800 \mu \mathrm{L}$ de amostra. O desenvolvimento da cor estará essencialmente completo em 2 min e permanecerá estável por um período de 1 hora $( \pm$ 4\%). Neste período, observa-se a absorbância do complexo a $595 \mathrm{~nm}$ em espectrofotômetro. Após o período de $1 \mathrm{~h}$, o complexo corante-proteína adquire dimensões muito elevadas e começa e precipitar. O valor obtido é plotado em uma curva-padrão estabelecida com quantidades conhecidas de uma proteína padrão como a fração $\mathrm{V}$ da albumina bovina, submetidas às mesmas condições. Assim, pode-se quantificar as proteína presentes na amostra (Apêndice 2). Interferentes da reação (Bradford, 1976) podem ser eliminados com o uso adequado de controles.

As frações com maior atividade de CMCase foram empregadas nos ensaios de otimização da cromatografia e na purificação das proteínas heterólogas.

\subsubsection{Cromatografia líquida em coluna}

A estratégia empregada para a clonagem e respectiva purificação de proteínas recombinantes contendo cauda de hexahistidinas, utiliza as vantagens da cromatografia de afinidade em metal. Os íons metálicos são imobilizados pelo uso de um agente quelante capaz de disponibilizar o metal para ligação à proteína (Nilsson et al., 1997). Certos aminoácidos, principalmente a histidina, apresentam alta afinidade pelo metal imobilizado. Assim, proteínas ricas em histidina ou com um grupo destes aminoácidos podem ser seletivamente eluídas da resina carregada com íons metálicos.

Entretanto, durante o desenvolvimento do presente trabalho, empregamos também cromatografia de troca iônica e cromatografia de exclusão molecular.

A cromatografia líquida em coluna foi efetuada com o auxílio do cromatógrafo 
de baixa pressão BioLogic LP $\left(\operatorname{BioRad}^{\circledR}\right)$, acoplado ao coletor de frações programável e os dados da cromatografia foram capturados com o auxílio do programa "LPDataView" $\left(\operatorname{BioRad}^{\circledR}\right)$.

\subsubsection{Cromatografia de afinidade em metal imobilizado (IMAC)}

A cromatografia de afinidade em metal (IMAC) foi efetuada com coluna HiTrapChelating HP de $1 \mathrm{~mL}$ (Sepharose $^{\mathrm{TM}}$ quelante de alta performance, uma agarose altamente ligada, com ácido iminodiacético ligado através de grupo éter estável; Amersham Biosciences; Uppsala - Suécia). Nesta técnica são empregados dois tampões: o tampão inicial é formado por fosfato sódio $20 \mathrm{mM} \mathrm{NaCl}$ 0,5 M pH 7,2. O tampão de eluição é formado pelo tampão inicial adicionado de imizadole a $0,5 \mathrm{M}(\mathrm{pH} 7,2)$. O metal imobilizado foi o sulfato de níquel $100 \mathrm{mM}$. Todas soluções foram preparadas, filtradas, autoclavadas e desgaseificadas durante $10 \mathrm{~min}$ antes do uso. Quando necessário, o pH foi ajustado

A coluna para IMAC foi inicialmente lavada com água (5 volumes de coluna). Em seguida foi aplicado $1 \mathrm{~mL}$ de metal (por exemplo o sulfato de níquel $100 \mathrm{mM}$ ) e novamente a coluna foi lavada com água (10 volumes). A água foi trocada pelo tampão inicial (5 volumes), seguido pelo tampão de eluição (tampão inicial com imidazole) com 5 volumes, retornando ao tampão inicial por mais 10 volumes de coluna. A amostra foi aplicada na coluna, lavada com tampão inicial e então com diferentes proporções de tampão inicial + tampão de eluição. A frações foram coletadas (usualmente de 1 a $2 \mathrm{~mL}$ ) e testadas quanto à atividade enzimática de acordo com o item 3.4.1.2 ou primeiramente agrupadas de acordo com o perfil de proteínas separadas e então avaliadas para CMCase (3.4.1.2).

Estas condições foram utilizadas preponderantemente nos ensaios. Entretanto, foram otimizadas após ensaios cromatográficos onde diversos tampões foram utilizados. Uma das variantes empregadas foi a descrita por Monteiro et al. (1999). A amostra proteica foi preparada em tampão Tris- $\mathrm{HCl} 50$ mM pH 8,0 e NaCl 500 mM. Esta amostra foi aplicada na coluna equilibrada em tampão Tri-HCl 50 mM pH 8,0 e NaCl 500 mM, glicerol 5 \% e DTT 1 mM. Após lavagem com oito volumes de coluna com o tampão inicial, foram aplicados 15 
volumes de coluna do tampão Tris- $\mathrm{HCl} 50$ mM pH 6,3 e NaCl 500 mM. Em seguida, foram aplicados 30 volumes de coluna do tampão inicial em gradiente de eluição com 0 a 200 mM de imizadole. O metal imobilizado foi níquel, na forma de sulfato de níquel (1 mL a $100 \mathrm{mM}$ ).

Outras variações testadas envolveram a utilização de tampão Tris-HCl 20 mM pH 7 e NaCl 500 mM e dos seguintes íons metálicos imobilizados : sulfato de zinco $100 \mathrm{mM}$, sulfato de cobre $100 \mathrm{mM}$ e cloreto de cobalto $100 \mathrm{mM}$. O tampão de eluição foi Tris- $\mathrm{HCl} 20$ $\mathrm{mM}$ pH 7,0 e $\mathrm{NaCl} 500 \mathrm{mM}$ com Imidazole $500 \mathrm{mM}$.

\subsubsection{Cromatrografia de troca aniônica}

A cromatografia de troca aniônica foi efetuada em coluna Econo-Pac High Q cartridge (suporte de troca iônica Macro-Prep ${ }^{\circledR}$ com grupo funcional $\mathrm{N}^{+}\left(\mathrm{CH}_{3}\right)_{3}$; BioRad). O tampão inicial foi formado por fosfato de sódio $20 \mathrm{mM} \mathrm{pH} \mathrm{7,2} \mathrm{e} \mathrm{as} \mathrm{proteínas} \mathrm{adsorvidas} \mathrm{foram}$ eluídas com $\mathrm{NaCl}$ no mesmo tampão. Empregamos eluição gradual das proteínas a 100 e 500 $\mathrm{mM}$ de $\mathrm{NaCl}$. Os tampões foram preparados, se necessário o $\mathrm{pH}$ foi ajustado, filtrados, autoclavados e antes do uso foram desgaseificados durante 10 min. A frações são coletadas e testadas quanto a atividade enzimática de acordo com o item 3.4.1.2 ou primeiramente agrupadas de acordo com o perfil de proteínas separadas e então avaliadas para CMCase (3.4.1.2).

\subsubsection{Cromatografia de filtração em gel}

A cromatografia de exclusão molecular foi efetuada em coluna de 1 x $58 \mathrm{~cm}$, preenchida com a resina Sephacryl S100HR (uma matriz hidrofílica rígida, formada por dextrana e bisacrilamida; Amersham Biosciences - Uppsala, Suécia) e a amostra foi eluída em tampão acetato de sódio $50 \mathrm{mM}$ pH 5,2. A frações (usualmente de 1 a $2 \mathrm{~mL}$ ) foram coletadas e testadas quanto à atividade enzimática de acordo com o item 3.4.1.2 ou primeiramente agrupadas de acordo com o perfil de proteínas separadas e então avaliadas para CMCase (3.4.1.2).

Amostras proteicas provenientes das etapas descritas no item 3.5 foram 
avaliadas quanto ao perfil eletroforético (item 3.4.1.3) após coloração com nitrato de prata (Anexo I).

\subsection{Caracterização enzimática das endoglicanases de $X$. fastidiosa}

As proteínas presentes no lisado das células de E. coli BL21(DE3)/ BL21(DE3)pLysS foram avaliadas quanto à atividade endoglicolítica (genes 810, 818 e 2708, ítem 3.6.1) (Shen et al., 1995; Wood \& Bath, 1998). Este lisado foi preparado como descrito no item 3.5.1 e submetido ao fracionamento com sulfato de amônio (3.5.2).

\subsubsection{Atividade endoglicolítica (celulase ou CMCase) sobre a carboximetil celulose}

A atividade de endoglicanase (celulase ou carboximetil celulase - CMCase) é efetuada com o substrato carboximetil celulose (CMC). A clivagem do substrato origina novas extremidade redutoras, as quais são posteriormente quantificadas. Desta maneira, um maior número de extremidades redutores denota maior atividade da enzima.

Uma unidade de enzima (EC 3.2.1.4 endoglicanase, $\beta$-1,4-endoglicanase, celulase ou CMCase;) é denominada como a quantidade de proteína em miligramas necessária para liberar $1 \mu \mathrm{mol}$ de açúcares redutores (igual a $0,18 \mu \mathrm{g}$ de glicose pelo método de Lever, 1972) do substrato por minuto (min), nas condições empregadas (Nankai et al., 1991; Fong \& Doi, 1992).

Para os ensaios descritos no subitem 3.6.1, utilizamos amostras proteicas provenientes de uma precipitação fracionada com sulfato de amônio efetuada sobre o lisado clarificado (item 3.5.2). Para as proteínas Xf - 818 (clone pNAW3) e Xf - 818r (clone pNAW4, recombinante) utilizamos o pelete da precipitação entre 40 e $80 \%$ de saturação de $\left(\mathrm{NH}_{4}\right)_{2} \mathrm{SO}_{4}$. Para as proteínas Xf -810 r (clone pNAW2, recombinante), Xf - 2708 (clone pNAW5) e Xf - 2708r (clone pNAW6, recombinante) utilizamos o sobrenadante da precipitação a $100 \%$ de saturação com $\left(\mathrm{NH}_{4}\right)_{2} \mathrm{SO}_{4}$. Assim, para cada proteína, testamos as seguintes quantidades de enzima, descritas em termos de Unidade enzimática. Para Xf -818 e Xf - 818r utilizamos $1 \mathrm{U}$; para Xf - 810r e Xf - 2708 utilizamos 0,18 U e para Xf - 2708r 
utilizamos $0,37 \mathrm{U}$. Todas estas amostras proteicas foram preparadas em tampão fosfato de sódio $20 \mathrm{mM}$ pH 7,2 com azida sódica a 0,05\%. Durante a realização dos ensaios, as amostras foram armazenadas a $4{ }^{\circ} \mathrm{C}$, sendo que amostras concentradas foram estocadas a $20{ }^{\circ} \mathrm{C}$. Nos ensaios onde empregamos nominalmente Unidade enzimática, esta estava contida em um volume de $50 \mu \mathrm{L}$ da amostra.

Determinamos a Unidade enzimática incubando-se $2,5 \mu \mathrm{g}$ de cada preparação enzimática acima descrita, com $200 \mu \mathrm{L}$ de CMC $1 \%$ em tampão acetato de sódio 50 mM pH 5,2 durante $2 \mathrm{~h}$ a $40{ }^{\circ} \mathrm{C}$.

\subsubsection{Determinação da atividade endoglicolítica em diferentes valores de $\mathbf{p H}$}

Nesta análise, o substrato CMC foi dissolvido a $1 \%(\mathrm{~m} / \mathrm{v})$ nos diferentes tampões empregados a $50 \mathrm{mM}$. Foram utilizados tampões que apresentaram variação de $\mathrm{pH}$ de 2,6 a 8,0 : tampão ácido cítrico - citrato de sódio em pH 2,6 - 3,0 - 3,6 - 4,3 - 5,4; tampão ácido acético - acetato de sódio em pH 4,3 - 4,7 - 5,0 - 5,2 - 5,6; tampão fosfato de sódio em pH 6,0 - 7,0 - 8,0. A reação consistiu de $50 \mu \mathrm{L}$ de cada preparação enzimática e $200 \mu \mathrm{L}$ do substrato $\mathrm{CMC}$, totalizando $250 \mu \mathrm{L}$. Este volume foi mantido a $40{ }^{\circ} \mathrm{C}$ durante 120 min em tubo de vidro, em banho - maria, com o nível de água cobrindo o espaço ocupado pela reação no tubo. Após este período, os tubos foram transferidos para um banho de água e gelo, e os carboidratos redutores presentes na reação foram quantificados (Lever, 1972). Foram efetuadas três avaliações para cada enzima em cada valor de $\mathrm{pH}$.

\subsubsection{Determinação da atividade endoglicolítica em diferentes molaridades}

Para a determinação da melhor concentração molar do tampão a se dissolver o substrato CMC, empregamos o tampão ácido acético - acetato de sódio pH 5,2 tomando-se por base os resultados obtidos na análise do ítem 3.6.1.1. Foram preparados tampões a 20, 50, 100, 150 e $200 \mathrm{mM}$ aos quais foi dissolvida CMC a $1 \%(\mathrm{~m} / \mathrm{v})$. A reação consistiu de 50 $\mu \mathrm{L}$ de cada preparação enzimática e $200 \mu \mathrm{L}$ do substrato $\mathrm{CMC}$, totalizando $250 \mu \mathrm{L}$. Este volume foi mantido a $40{ }^{\circ} \mathrm{C}$ durante $120 \mathrm{~min}$ em tubo de vidro, em banho - maria, com o nível 
de água cobrindo o espaço ocupado pela reação no tubo. Após este período, os tubos foram transferidos para um banho de água e gelo, e os carboidratos redutores presentes na reação foram quantificados (Lever, 1972). Foram efetuadas três avaliações para cada enzima em cada molaridade.

\subsubsection{Determinação da atividade endoglicolítica a diferentes tempos de incubação}

Nesta análise, o substrato CMC foi dissolvido em tampão ácido acético acetato de sódio $50 \mathrm{mM}$ pH 5,2 a $1 \%(\mathrm{~m} / \mathrm{v})$ nos ensaios para Xf - 810 e Xf - 818 e no mesmo tampão a $200 \mathrm{mM}$ para Xf - 2708. A reação consistiu de $50 \mu \mathrm{L}$ de cada preparação enzimática e $200 \mu \mathrm{L}$ do substrato $\mathrm{CMC}$, totalizando $250 \mu \mathrm{L}$. Este volume foi mantido a $40{ }^{\circ} \mathrm{C}$ durante $15 \mathrm{~min}, 30 \mathrm{~min}, 45 \mathrm{~min}, 60 \mathrm{~min}, 90 \mathrm{~min}, 2$ h, 4 h, $6 \mathrm{~h}$ e 18 h. Após este período, os tubos foram transferidos para um banho de água e gelo, e os carboidratos redutores presentes na reação foram quantificados (Lever, 1972). Foram efetuadas três avaliações para cada enzima em cada tempo.

\subsubsection{Determinação da atividade endoglicolítica sob diferentes temperaturas}

Nesta análise, o substrato CMC foi dissolvido em tampão ácido acético acetato de sódio $50 \mathrm{mM}$ pH 5,2 a $1 \%(\mathrm{~m} / \mathrm{v})$ nos ensaios para Xf -810 e Xf - 818 e no mesmo tampão a 200 mM para Xf - 2708. A reação consistiu de $50 \mu \mathrm{L}$ de cada preparação enzimática e $200 \mu \mathrm{L}$ do substrato $\mathrm{CMC}$, totalizando $250 \mu \mathrm{L}$. Este volume foi mantido a durante $1 \mathrm{~h}$ nas temperaturas de $4,20,25,30,35,40,45,50,55,60,65,70,75$ e $80{ }^{\circ} \mathrm{C}$. Após este período, os tubos foram transferidos para um banho de água e gelo, e os carboidratos redutores presentes na reação foram quantificados (Lever, 1972). Foram efetuadas três avaliações para cada enzima em cada temperatura.

\subsubsection{Degradação de polímeros pelas endoglicanases Xf-810, Xf-818 e Xf-2708}

Visando caracterizar o espectro de atividade das celulases, foram empregados diversos substratos poliméricos que apresentam ligações $\beta-1,4$ ou $\beta-1,3$. Foram testados 
CMC, Avicel (celulose microcristalina), celulose tratada com ácido, $\alpha$-celulose, goma xantana, xilana "birch wood", xilana "oat spels" e laminarina, sendo todos os substratos a $1 \%$ (m/v) em tampão acetato de sódio $50 \mathrm{mM}$ pH 5,2. Foram utilizados $50 \mu \mathrm{L}$ da preparação enzimática e $200 \mu \mathrm{L}$ dos substratos, totalizando $250 \mu \mathrm{L}$. Este volume foi mantido a $45{ }^{\circ} \mathrm{C}$ durante $2 \mathrm{~h}$. Após este período, os tubos foram transferidos para um banho de água e gelo, e os carboidratos redutores presentes na reação foram quantificados (Lever, 1972). Foram efetuadas quatro avaliações para cada enzima. No caso dos substrato insolúveis (Avicel, celulose tratada com ácido, $\alpha$-celulose, xilana "birch wood" e xilana "oat spels") os polímeros não degradados foram retirados da solução através de centrifugação (4 min a $12000 \mathrm{~g}$ ).

\subsubsection{Degração de celulose microcristalina}

A degradação de celulose microcristalina apresenta requerimentos diferentes do que a CMC devido a sua estrutura. Usualmente, a degradação deste polímero, também conhecido como Avicel, é efetuada por enzimas denominadas avicelases ou exoglicanases.

Avicel (celulose microcristalina), foi preparada a $1 \%(\mathrm{~m} / \mathrm{v})$ em tampão acetato de sódio $50 \mathrm{mM}$ pH 5,2. A celulose tratada com ácido ("phosphoric acid swollen cellulose" ACS) foi preparada com descrito no Anexo J, seguindo protocolo de Wood \& Bath (1988). Foram misturados $1 \mathrm{~mL}$ de preparação de Avicel com $50 \mu \mathrm{L}$ das preparações enzimáticas de Xf - 810 (clone pNAW1), Xf - 818 (clone pNAW3) e Xf - 2708 (clone pNAW5). O mesmo foi efetuado com celulose tratada com ácido. Foi preparado um tubo por período de avaliação, o que compreendeu avaliações nos tempos 0, 25, 40, 60, 120 e 1100 min de incubação a $65{ }^{\circ} \mathrm{C}$. Após os diferentes períodos, as amostras foram congeladas e posteriormente avaliadas quanto a presença de carboidratos redutores. Foram efetuadas duas avaliações para cada período. Os polímeros foram retirados da suspensão através de centrifugação (12 $000 \mathrm{~g} 4 \mathrm{~min}$ ) e o sobrenadante foi utilizado na avaliação de carboidratos redutores liberados (Lever, 1972). O tempo $0 \mathrm{~h}$ de incubação foi considerado como valor zero para descontar os carboidratos redutores presentes na amostra e no sobrenadante do polímero. 


\subsubsection{Hidrólise simultânea de CMC pelas endoglicanases de $X$. fastidiosa}

A capacidade de efetuar a hidrólise sinérgica da CMC foi avaliada pela incubação simultânea das celulases Xf -810 , Xf - 818 e Xf - 2708 juntamente com o substrato CMC $1 \%(\mathrm{~m} / \mathrm{v})$ em tampão acetato de sódio $50 \mathrm{mM}$ pH 5,2. Foram preparadas soluções contendo $1 \mathrm{U}$ de cada enzima em tampão acetato de sódio 50 mM pH 5,2 em 300 $\mu \mathrm{L}$. Assim, em cada tratamento, foi adicionado $1 \mathrm{U}$ da enzima a ser testada em $1100 \mu \mathrm{L}$ de CMC e o volume foi ajustado a $2 \mathrm{~mL}$, com tampão fosfato $20 \mathrm{mM} \mathrm{pH} \mathrm{7,2.} \mathrm{Os} \mathrm{tratamentos}$ consistiram das seguintes enzimas: Xf 810; Xf 818; Xf 2708; Xf $810+$ Xf 818; Xf $810+$ Xf 2708; Xf $818+$ Xf 2708; Xf $810+$ Xf $818+$ Xf 2708. Estas enzimas foram incubadas a 40 ${ }^{\circ} \mathrm{C}$ durante $2 \mathrm{~h}$, sendo então fervidas 5 min para inativação. Foram efetuadas três avaliações de carboidratos redutores para cada tratamento (Lever, 1972).

\subsubsection{Produção de oligômeros derivados da celulose e degradação de celo- oligossacarídeos pelas endoglicanases Xf-810, Xf-818 e Xf-2708}

As amostras utilizadas para a quantificação de açúcares redutores liberados de Avicel e celulose tratada com ácido (item 3.6.2.1), foram utilizadas para avaliar a produção de celooligossacarídeos. A determinação qualitativa da produção de glicose, celobiose, celotriose, celotetrose e celopentose foi efetuada através de cromatografia de camada delgada, seguindo o protocolo de Bounias (1980). Placas de alumínio recobertas com sílica-gel foram lavadas com tampão fosfato de sódio $200 \mathrm{mM} \mathrm{pH} \mathrm{7,2} \mathrm{e} \mathrm{secas.} \mathrm{As} \mathrm{amostras} \mathrm{foram} \mathrm{aplicadas}$ (35 ou $40 \mu \mathrm{L}$, dependendo do ensaio) com uma distância de $12 \mathrm{~mm}$ umas das outras, $10 \mathrm{~mm}$ de distância da borda da placa e 1,5 cm acima do bordo inferior da placa. Foram incluídos os oligossacarídeos acima descritos, como padrão, sendo aplicados $10 \mu \mathrm{L}$ de uma mistura contendo $2 \mathrm{mM}$ de cada açúcar. As amostras foram secas sob ar e eluídas com uma mistura de clorofórmio:ácido acético:água $(6: 7: 1 \mathrm{v} / \mathrm{v} / \mathrm{v})$. A placa foi eluída em ambiente fechado até a migração atingir cerca de $3 / 5$ da altura da placa $(20$ x $20 \mathrm{~cm})$. As cromatofolhas foram então secas sob corrente de ar e o processo repetido uma ou duas vezes nas mesmas condições. 
Terminada a eluição, as placas foram secas e uma solução 6,5 mM de $N$-(1naftil)etilenodiamina dihidrocloreto foi aplicada sobre a placa na forma de aspersão. Este reagente é preparado em metanol (97 \%) e ácido sulfúrico (3\% v/v) e após aplicação, a placa é aquecida a $100{ }^{\circ} \mathrm{C}$ durante 5 a 10 min em estufa. Os açúcares são visualizados inicialmente com coloração rosa-avermelhada, a qual evolui gradualmente até cinza escuro (Bounias, 1980). Após resfriamento, as placas foram registradas (fotografadas), pois ocorre escurecimento da placa, dificultando a posterior visualização.

$\mathrm{Na}$ determinação da hidrólise de celobiose, celotriose, celotretrose e celopentose pela celulases, foram empregados $20 \mu \mathrm{L}$ de cada amostra da mesma preparação enzimática utilizada no ítem 3.6.2.1, juntamente com $10 \mu \mathrm{L}$ de cada açúcar a $10 \mathrm{mM}$. Ambos os reagentes foram misturados e incubados a $40{ }^{\circ} \mathrm{C}$ em banho-maria durante 4 ou $6 \mathrm{~h}$. Estas amostras foram aplicadas, eluídas e reveladas nas cromatofolhas como descrito acima. Através da migração diferencial dos açúcares de acordo com seu grau de polimerização, é possível compará-los ao padrão e inferir quais oligômeros foram formados (Bounias, 1980; Kim, 1995; Zhou \& Ingram, 2000).

\subsubsection{Ligação à celulose cristalina}

Efetuamos um teste para ligação à celulose cristalina de acordo com Park et al. (2000). Neste ensaio, $15 \mathrm{mg}$ de celulose microcristalina (Avicel) foram lavadas com $1 \mathrm{~mL}$ de Tris-HCl 20 mM pH 7,0; NaCl 200 mM e EDTA 1 mM. Esta suspensão foi centrifugada e ao pelete foi adicionado a amostra protéica, sendo mantida uma hora sob agitação em temperatura ambiente. Esta suspensão foi centrifugada, o pelete de celulose foi lavado com $1 \mathrm{~mL}$ de tampão, misturado (vórtex) e novamente centrifugado. Repetiusse esta etapa 5 vezes. O pelete foi ressuspenso em tampão e uma alíquota de $100 \mu \mathrm{L}$ foi incubada com $200 \mu \mathrm{L}$ de tampão acetato $50 \mathrm{mM}$ pH 5,2 e $200 \mu \mathrm{L}$ de CMC $1 \%$ em tampão acetato 50 mM pH 5,2. Após períodos de $0,15,30,60$ e 120 min de incubação a $40{ }^{\circ} \mathrm{C}$, a suspensão foi centrifugada e a quantidade de carboidratos redutores foi avaliada.

Outra forma de avaliação da ligação à celulose foi adicionar $1 \mathrm{U}$ de cada 
enzima Xf - 810 e Xf - 2708 e 10 U de Xf - 818 a 10 mg de avicel em $1500 \mu L$ de tampão fosfato de sódio $20 \mathrm{mM} \mathrm{pH} \mathrm{7,2.} \mathrm{Foi} \mathrm{mantida} \mathrm{sob} \mathrm{agitação} \mathrm{rotativa} \mathrm{(12} \mathrm{rpm)} \mathrm{durante} 6 \mathrm{~h} \mathrm{a}$ temperatura ambiente. Esta suspensão foi então centrifugada $12000 \mathrm{~g}$ por 5 min e as proteína ligadas à celulose foram lavadas com fosfato de potássio $20 \mathrm{mM} \mathrm{pH} \mathrm{7,0} \mathrm{NaCl} 1 \mathrm{~mL}$ e centrifugadas novamente (este passo foi repetido 2 vezes). Depois, a celulose foi lavada com fosfato de potássio $50 \mathrm{mM} \mathrm{pH} \mathrm{7,0} \mathrm{da} \mathrm{mesma} \mathrm{maneira} \mathrm{que} \mathrm{acima} \mathrm{descrito} \mathrm{e} \mathrm{por} \mathrm{final} \mathrm{lavada}$ com água $(2 \mathrm{X})$. Ao pelete final de celulose foram adicionados $50 \mu \mathrm{L}$ de tampão da amostra desnaturante (Anexo G), fervido 5 min e novamente centrifugado. O sobrenadante foi utilizado para analisar as protéinas ligadas à celulose através de eletroforese (item 3.4.1.3). 


\section{RESULTADOS}

\subsection{Estrutura das celulases de $X$. fastidiosa}

Muitas enzimas contém domínios múltiplos, mas a classificação é feita com base na similaridade da sequiência de aminoácidos do domínio catalítico ou putativamente catalíticos (Gilkes et al., 1991; Henrissat, 1991). Os genes Xf - 810, Xf - 818 e Xf - 2708 apresentam similaridade de sequiência com endoglicanases e a similaridade de seu domínio catalítico classifica-as como pertencentes à família 5 das hidrolases glicosídicas. Por outro lado, o gene Xf - 1267 apresenta similaridade de seqüência com celobiohidrolases ou exoglicanases e o seu domínio catalítico pertence à família 6 das hidrolases glicosídicas.

A organização modular da proteína Xf - 818 (Figura 7) é semelhante à celobiohidrolase A (CbhA) e endoglicanases B e D (CenB e CenD) de Cellulomonas fimi (Meinke et al., 1993). O domínio catalítico é N-terminal, enquanto o domínio ligador de celulose (CBD) é C-terminal e separado por uma sequiência ligadora. Entretanto, estas enzimas pertencem a diferentes famílias, CbhA pertence à família 6 (B), CenD à família 5 e CenB à família 9. As proteínas Xf - 818 e Xf - 1267 apresentam um DLC do tipo II na extremidade C-terminal e ambas apresentam sequiências conhecidas como conectores. Em Xf - 818 esta região compreende 132 aminoácidos que apresentam a seguinte composição: $70,45 \%$ de glicina $(\mathrm{G}), 28,79 \%$ de serina $(\mathrm{S})$ e $0,76 \%$ de treonina $(\mathrm{T})$. Em Xf - 1267 a região conectora compreende 121 aminoácidos com $80 \%$ de serina e $20 \%$ de glicina.

Analisando os aminoácidos conservados na família 5 das hidrolases glicosídicas, Wang et al. (1993) observaram que sete destes são estritamente conservados 


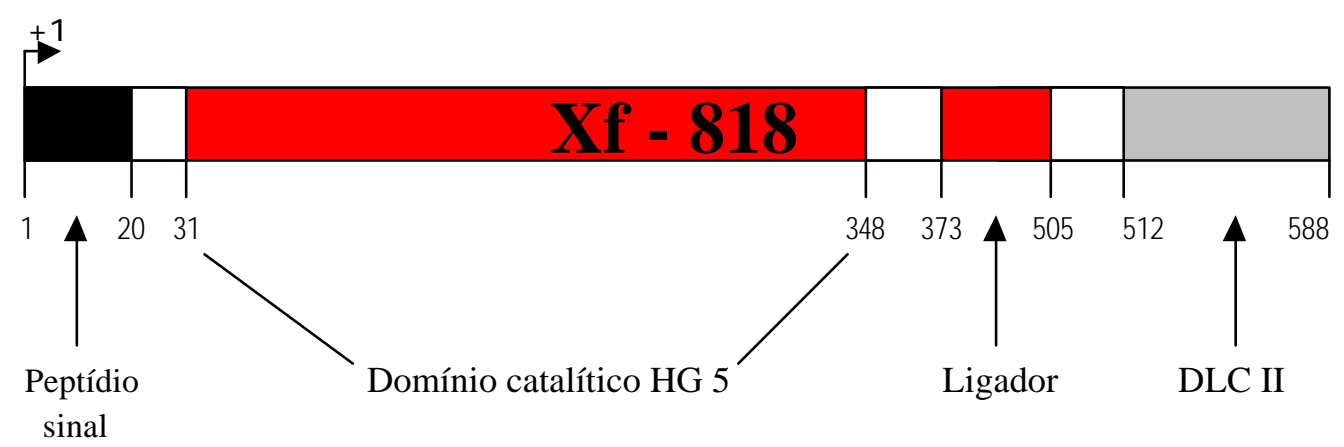

Clivagem em
LSA AP

Este domínio possui os aminoácidos conservados $\mathbf{E}^{181}$ e $\mathbf{E}^{303}$, potencialmente localizados no centro catalítico e envolvidos na hidrólise glicosídica $\beta-1,4$

$\begin{array}{cc}\text { Seqüência } & \text { Apresenta cinco } \\ \text { composta } & \text { radicais } \\ \text { de resíduos } & \text { triptofano }(W) \\ \text { de glicina } & \text { conservados, } \\ (70 \%) \text { e } & \text { flanqueados por } \\ \text { serina } & \text { uma cisteína } \\ (29 \%) & \text { de cada lado. }\end{array}$

Figura 7 - Estrutura da proteína Xf - 818 com base na seqüência de aminoácidos traduzida a partir da sequiência de nucleotídeos determinada durante o seqüenciamento do genoma de X. fastidiosa 9a5c (Simpson et al., 2000). Peptídio sinal teórico calculado com SignalP V1.1 (Nielsen et al., 1997; http://www.cbs.dtu.dk/services/SignalP/). Domínio catalítico similar às hidrolases glicosídicas da família 5 (Coutinho \& Henrissat, 1999; http://afmb.cnrsmrs.fr/ cazy/CAZY/index.html). DLC - Domínio ligador de celulose pertencente a família 2 dos módulos ligadores de celulose. Os números abaixo da representação gráfica referem-se aos aminoácidos de cada domínio com uma descrição das principais características de cada região. 
em todas as proteínas. Comparando a posição destes aminoácidos em relação a CelC de Clostridium thermocelum (Tabela 8) nas celulases de X. fastidiosa, na endoglicanase EngXCA de X. c. campestris (Gough et al., 1990) e em Cel5 de E. chrysanthemi (Guiseppi et al., 1988), tem-se que, enquanto o nucleófilo sítio ativo ácido glutâmico é estritamente conservado em todas enzimas, o ácido glutâmico catalista ácido base não está presente em Xf - 810, estando em seu lugar uma histidina $\left(\mathrm{H}^{163}\right)$. O ácido glutâmico nucleófilo é encontrado em todas as hidrolases glicosídicas da família 5, assim como outros seis aminoácidos extremamente conservados (Baird et al., 1990; Belaich et al., 1992; Guiseppi et al., 1988; Wang et al.,1993).

Tabela 8. Posição dos sete aminoácidos conservados nas hidrolases glicosídicas da família 5, como determinado por Wang et al. (1993) com base na endoglicanase CelC de Clostridium thermocellum e suas posições relativas nas celulases de $X$. fastidiosa 9 a5c. *

\begin{tabular}{lllllllll}
\hline Enzima & \multicolumn{5}{c}{ Aminoácido conservado } & \multicolumn{1}{l}{ Referência } \\
\cline { 2 - 6 } CelC & $\mathrm{R}^{46}$ & $\mathrm{H}^{90}$ & $\mathrm{~N}^{139}$ & $\mathrm{E}^{140}$ & $\mathrm{H}^{198}$ & $\mathrm{Y}^{200}$ & $\mathrm{E}^{280}$ & \\
\hline Xf-810 & $\mathrm{R}^{60}$ & $\mathrm{H}^{88}$ & $\mathrm{~N}^{162}$ & $\mathbf{H}^{\mathbf{1 6 3}}$ & $\mathrm{S}^{\mathbf{2 6 4}}$ & $\mathrm{D}^{\mathbf{2 6 6}}$ & $\mathrm{E}^{333}$ & Simpson et al., 2000 \\
Xf-818 & $\mathrm{R}^{82}$ & $\mathrm{H}^{135}$ & $\mathrm{~N}^{180}$ & $\mathrm{E}^{181}$ & $\mathrm{H}^{260}$ & $\mathrm{Y}^{262}$ & $\mathrm{E}^{303}$ & Simpson et al., 2000 \\
Xf-2708 & $\mathrm{R}^{82}$ & $\mathrm{H}^{125}$ & $\mathrm{~N}^{168}$ & $\mathrm{E}^{169}$ & $\mathrm{H}^{240}$ & $\mathrm{Y}^{242}$ & $\mathrm{E}^{282}$ & Simpson et al., 2000 \\
EngXCA & $\mathrm{R}^{83}$ & $\mathrm{H}^{136}$ & $\mathrm{~N}^{181}$ & $\mathrm{E}^{182}$ & $\mathrm{H}^{261}$ & $\mathrm{Y}^{263}$ & $\mathrm{E}^{303}$ & Gough et al., 1988 \\
Cel5 & $\mathrm{R}^{57}$ & $\mathrm{H}^{98}$ & $\mathrm{~N}^{132}$ & $\mathrm{E}^{133}$ & $\mathrm{H}^{192}$ & $\mathrm{Y}^{194}$ & $\mathrm{E}^{220}$ & Guiseppi et al., 1988 \\
\hline
\end{tabular}

1 A posição refere-se àquela ocupada pelo aminoácido na estrutura primária da proteína; aa em negrito são os dissimilares àqueles observados no consenso da família 5 . $\mathrm{E}^{140}$ é o catalista ácido base e $\mathrm{E}^{280}$ o nucleófilo sítio ativo (CelC)

2 A endoglicanase de $X$. campestris pv. campestris foi incluída para termos comparativos por apresentar similaridade com as celulases de $X$. fastidiosa 9a5c;

3 A endoglicanase de E. chrysanthemi foi inclída para termos comparativos devido aos estudos estruturais efetuados (Py et al., 1991; Chapon et al., 2001).

* Consultar o Apêndice 3 para observar a mesma comparação nas endoglicanases de outros isolados de $X$. fastidiosa. 
Além deste ácido glutâmico, a histidina relativa a $\mathrm{H}^{198}$ de CelC é substituída por serina $\left(S^{264}\right)$ em Xf - 810, sendo que esta histidina é essencial para a catálise em Cel5 de $E$. chrysanthemi. $\mathrm{O}$ outro aminoácido conservado, tirosina $\left(\mathrm{Y}^{200}\right)$, é substituído por ácido aspártico (Tabela 8).

\subsection{Clonagem dos genes da $X$. fastidiosa nos vetores de expressão}

No presente trabalho, obtivemos sucesso na amplificação de todos os genes de interesse (Figura 8) em quantidades suficientes para procedermos a posterior clonagem. A clonagem destes fragmentos de DNA resultantes da amplificação foi efetuada após digestão dos fragmentos e do plasmídio de expressão com as enzimas de restrição NdeI e HindIII. Estes sítios de restrição foram inseridos nos iniciadores empregados para a amplificação dos genes (3.3.2), de forma a permitir sua clonagem nos vetores de expressão pET20b e pET28b. Um detalhe que deve ser lembrado é a baixa eficiência de clivagem da enzima de restrição NdeI, a qual requer DNA de boa qualidade, isto é, sem impurezas para que ocorra uma boa digestão enzimática. Assim, sempre que foi necessário empregar esta enzima para digestão de DNA plasmidial, empregamos um protocolo de produção de DNA com fenol (Anexo A). Na clivagem de DNA amplificado através da PCR, a simples retirada dos sais (Anexo B) foi suficiente para permitir a clivagem.

Os clones resultantes de cada transformação (3.3.3) foram analisados através do seu perfil de restrição (Figura 9). Nesta análise, o tamanho do inserto pode ser avaliado pela clivagem do plasmídio em sítios de restrição adjacentes ao ponto no qual o inserto foi clonado, com posterior eletroforese em gel de agarose. A confirmação do tamanho do inserto nos clones selecionados através do perfil de restrição foi efetuada através de amplificação na PCR (Figura 10). Foram empregados os iniciadores promotor T7 e terminador T7, com os quais é possível a amplificação do inserto clonado nos vetores pET20b e pET28b e a estimativa de seu tamanho após eletroforese em gel de agarose. 


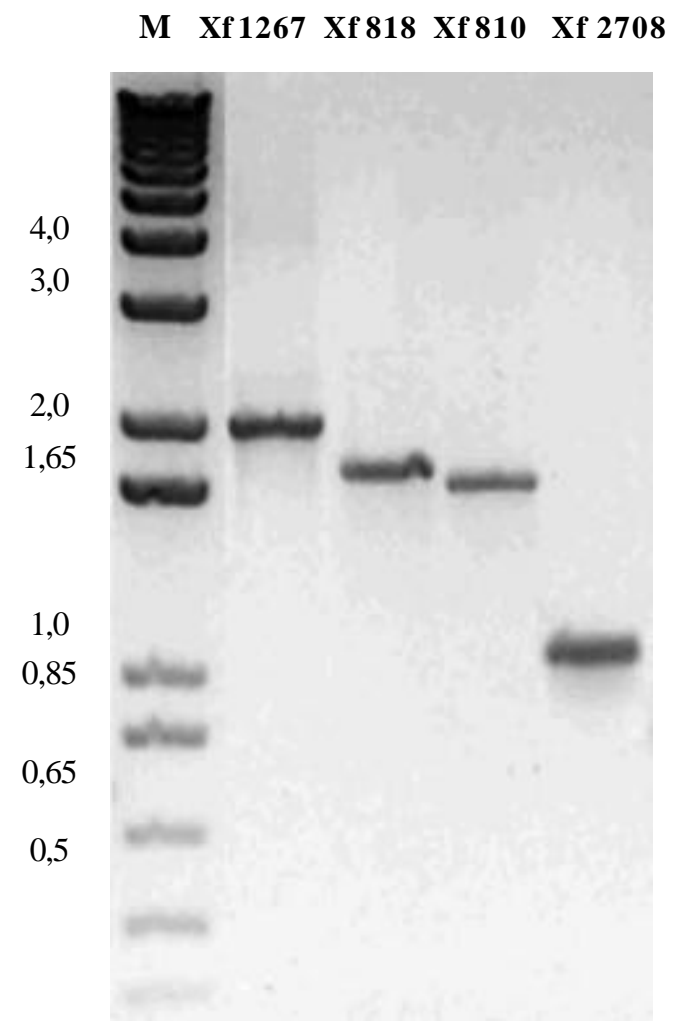

Figura 8 - Genes de Xylella fastidiosa 9a5c amplificados através da PCR e separados em eletroforese em gel de agarose $0,8 \%$. Foram empregados os iniciadores descritos na Tabela 6 para a amplificação dos genes Xf-1267 (celobiohidrolase), Xf-818, Xf-810 e Xf-2708 (endoglicanases). M - marcador de massa molecular $1 \mathrm{~kb}$ plus DNA Ladder (Gibco BRL), com massa em kpb. 


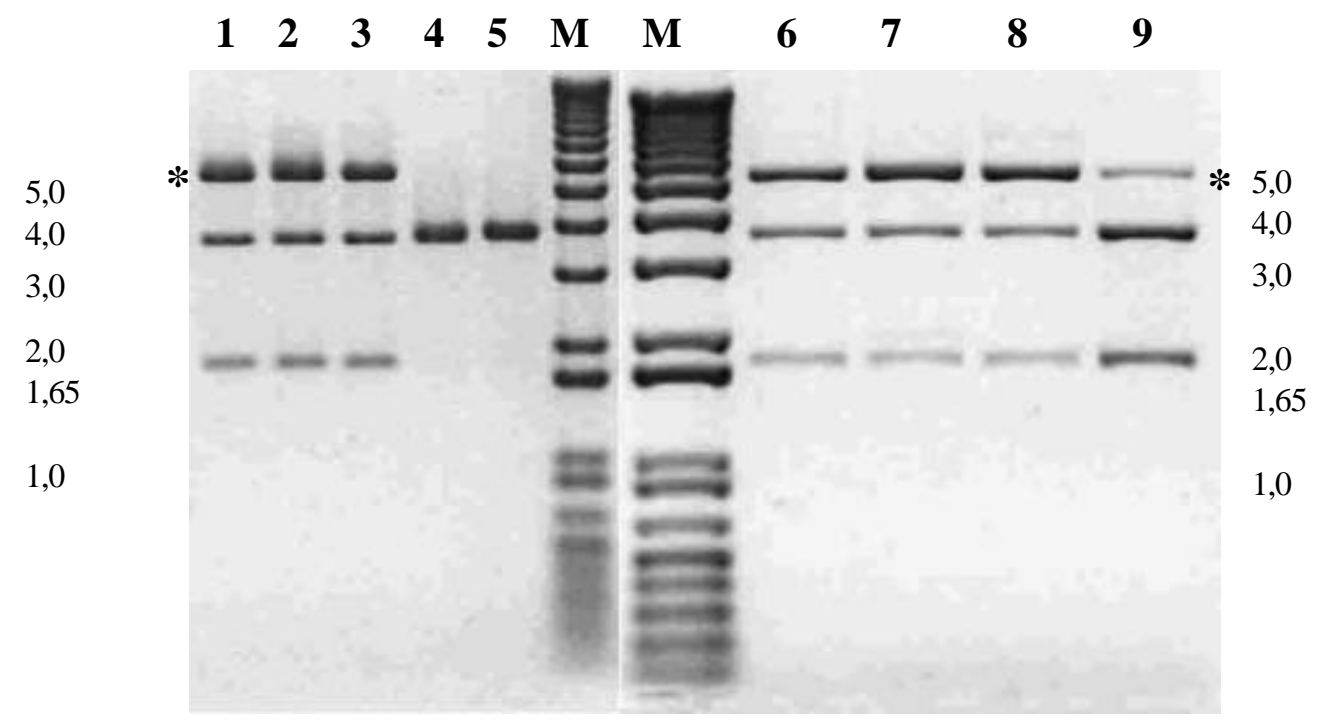

Figura 9 - Perfil de restrição de plasmídios para verificação da presença de inserto. Linhas 1 a 3, clones positivos para clonagem de Xf - 818 em pET20b (como em pNAW3). Linhas 4 e 5 clones negativos, representam o plasmídio pET20b. Linhas 6 a 9, clones positivos para clonagem de Xf - 810 em pET20b (como em pNAW1). Os plasmídios foram extraídos de E. coli DH5 $\alpha$ e digeridos com as enzimas de restrição NdeI e HindIII. A banda de maior massa (*) representa o plasmídio linearizado, o qual não foi totalmente clivado pelas enzimas. Os fragmentos de DNA foram separados em eletroforese em gel de agarose 0,8 \%. M - marcador de massa molecular $1 \mathrm{~kb}$ plus DNA Ladder (Gibco BRL), com massa em kpb. 


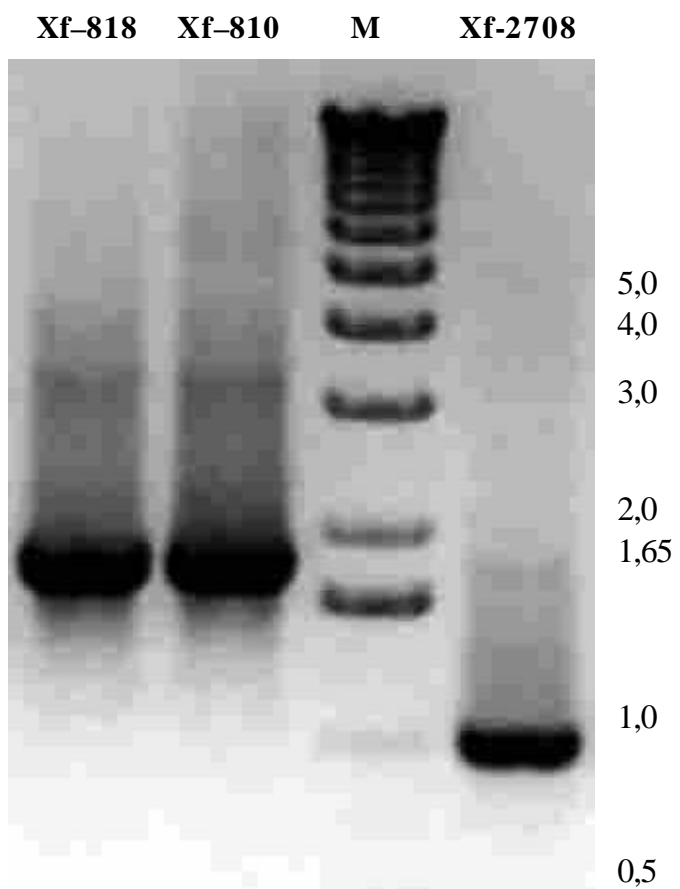

Figura 10 - Confirmação do tamanho do inserto amplificado através da PCR. O DNA plasmidial foi amplificado com os iniciadores promotor T7 e terminador T7. O produto da amplificação foi separado em eletroforese em gel de agarose 0,8 \%. Plasmídios pNAW3 (Xf-818), pNAW1 (Xf-810) e pNAW5 (Xf-2708). M - marcador de massa molecular $1 \mathrm{~kb}$ DNA Ladder (Gibco BRL), com massa em kpb. 
Desta forma efetuamos a clonagem dos genes Xf - 810, Xf - 818 e Xf - 2708, que codificam endoglicanases de $X$. fastidiosa 9a5c. A descrição dos plasmídios que foram construídos com base nos vetores de expressão pET20b e pET28b pode ser observada na Tabela 4 e Tabela 9. Foram construídos plasmídios para expressão heteróloga destas enzimas em três possíveis formas: proteína nativas, como encontradas em $X$. fastidiosa(1); proteínas recombinantes na extremidade $\mathrm{N}$-terminal (2) ou C- terminal (3), com fusão de uma sequiência hexastidina, conhecida como His ${ }_{6}$ tag (Tabela 9). A incorporação desta cauda de histidinas visa a purificação da proteína recombinante através de cromatografia de afinidade em metal imobilizado (item 4.3). Na Tabela 9, podemos observar os aminoácidos adicionais incorporados na extremidade $\mathrm{N}$ - ou C- terminal, criando o $\mathrm{His}_{6}$ tag.

Após diversas tentativas, não obtivemos sucesso na clonagem do gene Xf 1267 (possível celobiohidrolase) nos vetores pET20b ou pET28b.

Os clones contendo os genes clonados nos vetores de expressão (Tabela 9) foram empregados na produção de proteínas expressas de forma heteróloga em E. coli BL21(DE3).

\subsection{Seleção dos clones e otimização da produção das proteínas heterólogas}

Entre três e sete clones oriundos da transformação das linhagens de E. coli BL21(DE3) ou BL21(DE3)pLysS com os plasmídios listados na Tabela 9 foram avaliados em meio LB + CMC 0,1\% para a degradação de celulose (item 3.4.1.1). Neste teste, podem ser visualizados os clones que produzem a proteína heteróloga, pois a mesma degrada a CMC presente no meio de cultura, o que pode ser visualizado pela formação de um halo amarelo contra o fundo vermelho (Figura 11). Os mesmos clones foram avaliados quanto à produção de celulase pelo método espectrofotométrico indireto (item 3.4.1.2), onde podemos quantificar a atividade celulásica de cada clone. A produção da proteína heteróloga destes clones também foi

avaliada através

de

SDS 
Tabela 9. Plasmídios produzidos pela clonagem dos genes de $X$. fastidiosa 9a5c nos vetores de expressão pET20b(+) e pET28b(+) e as respectivas terminações amina e carboxila.

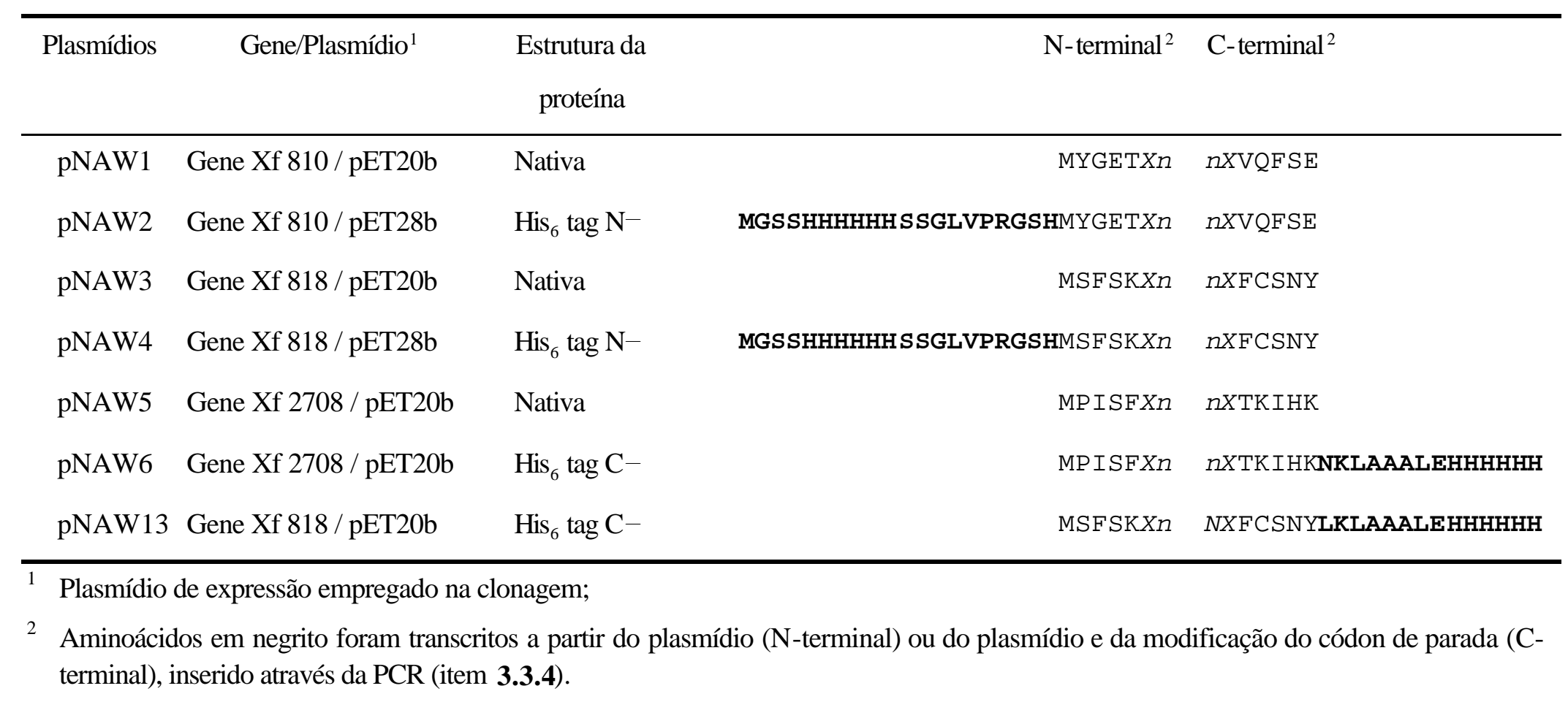




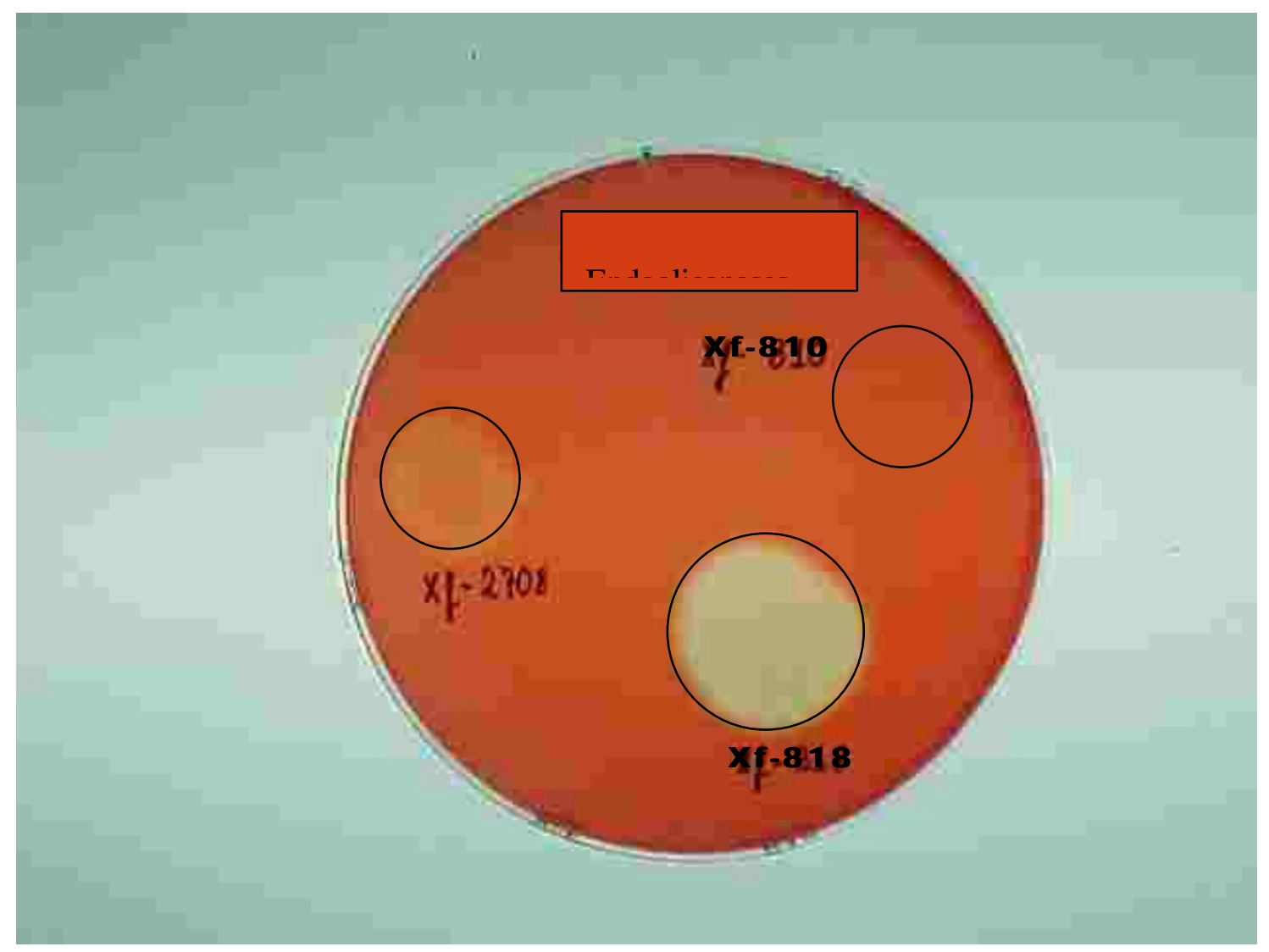

Figura 11 - Ensaio em placa para endoglicanase. Clones de E. coli BL21(DE3), portadores dos plasmídios pNAW3 (Xf-818), pNAW1 (Xf-810) e pNAW5 (Xf-2708) induzidos com IPTG 0,4 mM, foram mantidos durante uma noite a $37{ }^{\circ} \mathrm{C} \mathrm{em}$ meio de cultura LB/CMC. A degradação da celulose é revelada após coloração com vermelho congo (item 3.4.1.1) e descoloração com $\mathrm{NaCl} 1 \mathrm{M}$. O halo amarelo indicada a hidrólise da celulose, uma característica das endoglicanases (EC 3.2.1.4). 
PAGE e CMC - SDS - PAGE. Nestas duas técnicas, a quantidade de proteína heteróloga e a atividade enzimática da proteína heteróloga podem ser avaliadas.

A seguir, são apresentados alguns resultados para os clones oriundos da transformação com os plasmídios pNAW1 e pNAW3. As avaliações da produção de celulase foram quantificadas através de método espectrofotométrico (Tabela 10) e a partir de uma observação comparativa do tamanho dos halos produzidos em meio de cultura contendo CMC, onde apenas foi feita a diferenciação entre positivo (degradou celulose) e negativo (não degradou celulose). Na Figura 12, podem ser observadas as proteínas totais de sete clones de E. coli BL21(DE3) contendo o plasmídio pNAW3 induzidos ou não com IPTG 0,4 mM. As proteínas foram separadas através de eletroforese e visualizadas após coloração com azul de Coomassie. Utilizando os clones pNAW3/BL21(DE3) como modelo, podemos afirmar com base na atividade CMCásica em placa, no ensaio espectrofotométrico e na eletroforese que o clone denominado pNAW3b pode ser considerado um bom produtor da proteína heteróloga.

A mesma forma de análise foi empregada com os outros clones derivados das transformações com os plasmídios contendo os genes de X. fastidiosa. Desta seleção foram escolhidos os clones considerados bons produtores da proteína heteróloga. Estes foram armazenados em glicerol $\mathrm{a}-80^{\circ} \mathrm{C}$ e utilizados nos ensaios subseqüentes.

Dois fatores que podem ser preponderantes na produção e subseqüente acúmulo de proteínas heterólogas é o tempo de cultivo após a adição do indutor e a temperatura em que a cultura é mantida quando da adição deste indutor. Visando otimizar este processo, os clones pNAW1, pNAW3 e pNAW5 foram induzidos com IPTG 0,4 mM nas temperaturas de 28, 32 e $37{ }^{\circ} \mathrm{C}$ e a produção da proteína heteróloga foi avaliada através de ensaio espectrofotométrico e SDS - PAGE. A Figura 13 ilustra as proteína separadas através de eletroforese do clone pNAW3b em diferentes tempos após a indução com IPTG nas temperaturas de 28 e $37{ }^{\circ} \mathrm{C}$. Podemos observar que quanto maior o tempo após a indução com IPTG, maior é o acúmulo da proteína heteróloga. A cinética de acúmulo é diferente, ocorrendo um maior acúmulo na temperatura mais elevada. Entretanto, o acúmulo de proteína é aparentemente maior na 
Tabela 10. Atividade de CMCase presente no sobrenadante da cultura dos clones de E. coli BL21(DE3) contendo os plasmídios pNAW1 ou pNAW3, induzidos com IPTG 0,4 mM.

\begin{tabular}{lccc}
\hline Clone $^{1}$ & $\mu g$ glicose liberada & $\mathrm{AE}^{2}$ & Ensaio em placa $^{3}$ \\
\hline pNAW1a ** & $2,06 \pm 1,1$ & 2,33 & Positivo \\
pNAW1b & 0 & 0 & Negativo \\
pNAW1c & $0,31 \pm 2$ & 0,32 & Negativo \\
pNAW1d & $1,21 \pm 0,61$ & 1,16 & Positivo \\
pNAW1e & $0,55 \pm 1,79$ & 0,37 & Positivo \\
pNAW1f & $1,32 \pm 2,52$ & 1,26 & Negativo \\
pNAW1g & $0,03 \pm 1,92$ & 0 & Positivo \\
pNAW3a & $3,41 \pm 0,56$ & 2,65 & Positivo \\
pNAW3b ** & $7,02 \pm 1,48$ & 5,52 & Positivo \\
pNAW3c & $1,67 \pm 0,27$ & 1,41 & Positivo \\
pNAW3d & $3,64 \pm 0,17$ & 2,94 & Positivo \\
pNAW3e & $3,96 \pm 0,94$ & 3,26 & Positivo \\
pNAW3f & $3,95 \pm 1,2$ & 3,30 & Positivo \\
pNAW3g & $1,55 \pm 0,53$ & 1,14 & Positivo \\
\hline
\end{tabular}

1 Clones resultantes da transformação do referido plasmídio em BL21(DE3). O duplo asterisco indica o clone selecionado para a produção da proteína heteróloga (item 3.5). Média de 3 repetições seguida de desvio padrão da média;

$2 \mathrm{AE}=$ Atividade específica ( $\mu \mathrm{g}$ glicose liberada/mg proteína da amostra $/ \mathrm{min})$;

3 Ensaio efetuado como em 3.4.1.1 crescendo-se um clone em meio LB sólido/CMC $0,1 \%$, depois corado com vermelho congo e descorado com $\mathrm{NaCl} 1 \mathrm{M}$. Positivo denota capacidade de degradar celulose, enquanto negativo não apresenta esta capacidade. 


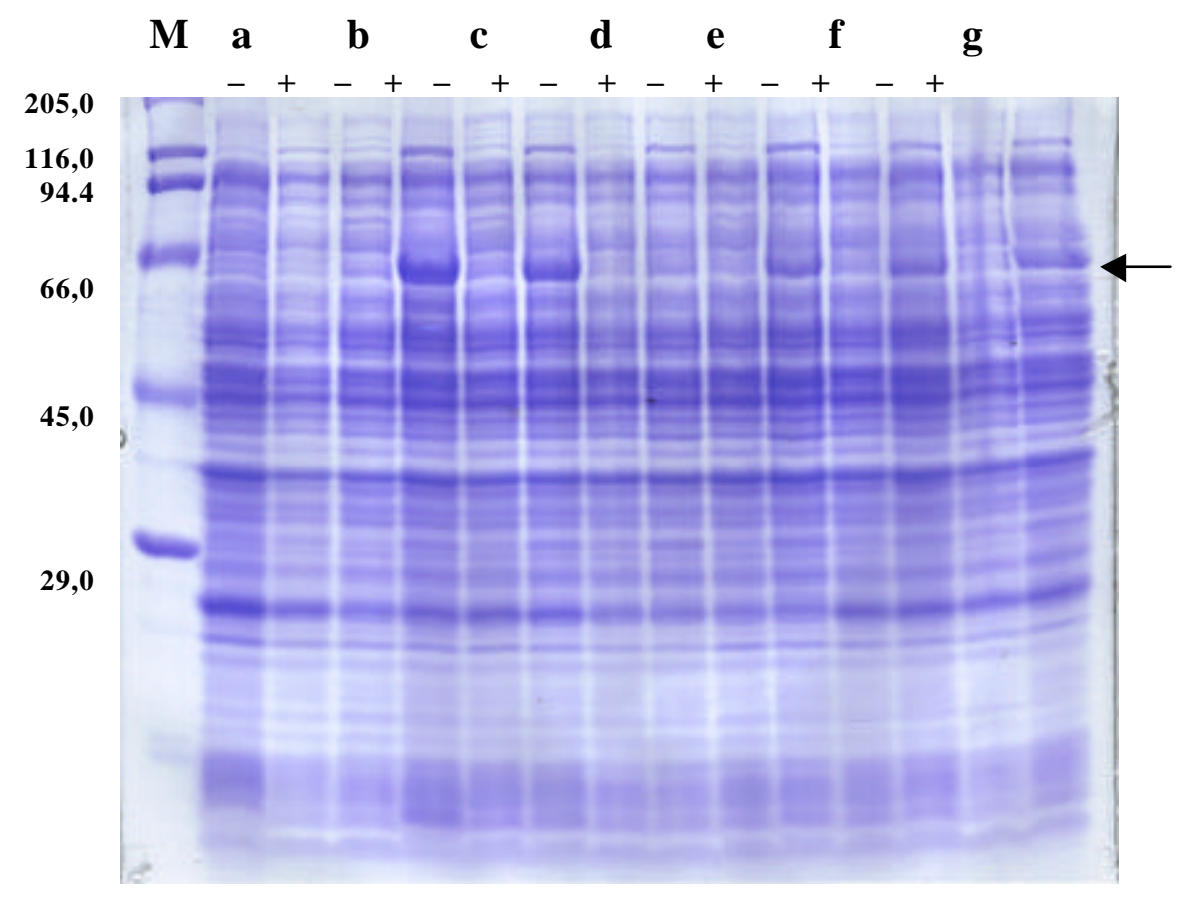

Figura 12 - Eletroforese em gel desnaturante (SDS-PAGE) de clones de E. coli BL21(DE3) com o plasmídio pNAW3 expressando a proteína XF - 818 nativa (seta). As letras referem-se aos clones testados; - e + referem-se a clones sem e com indução por IPTG 0,4 mM, respectivamente. 10 \% T. M marcador de massa molecular em $\mathrm{kDa}$ (SDS - 6H, Sigma).

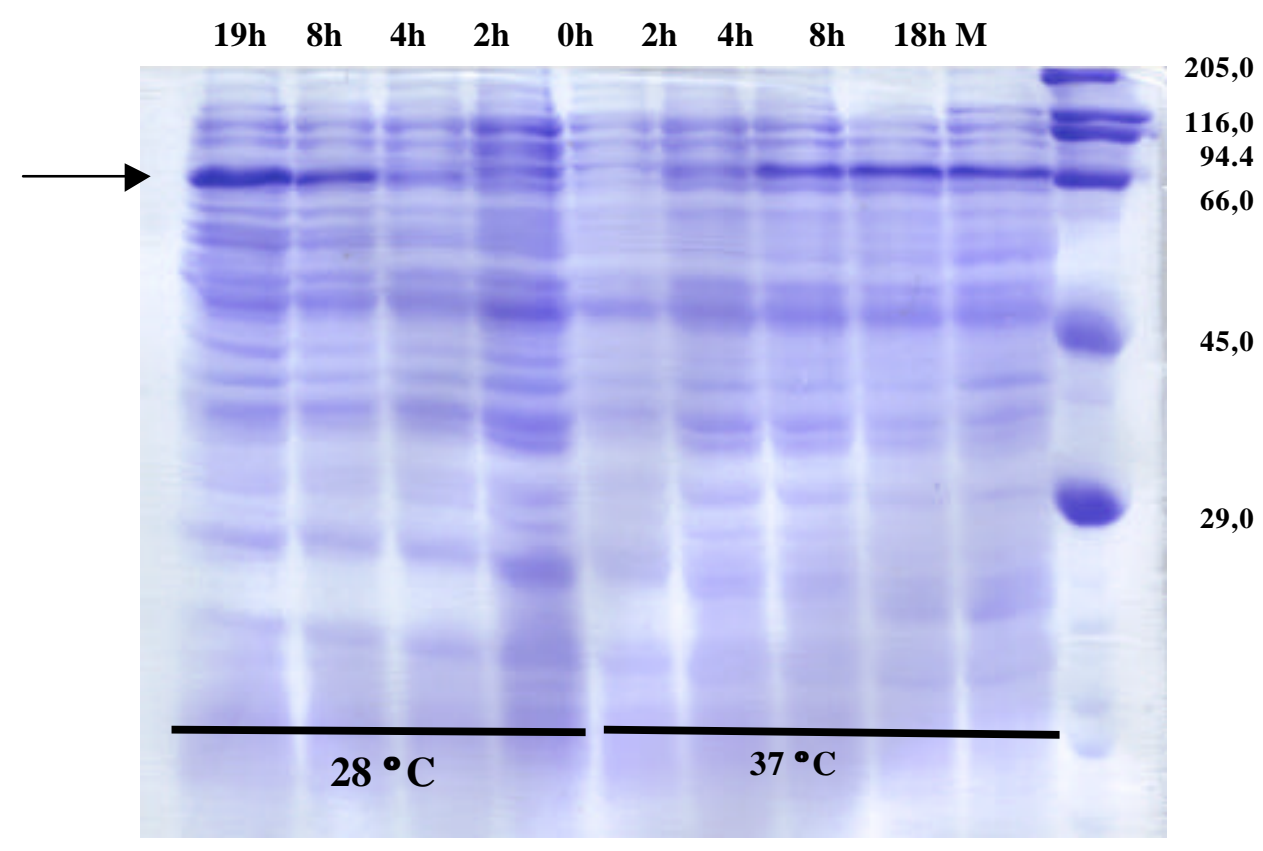

Figura 13 - Eletroforese em gel desnaturante (SDS-PAGE) do clone b de E. coli BL21(DE3) com o plasmídio pNAW3 expressando a proteína $\mathrm{XF}$ - 818 nativa (seta), em diferentes tempos após indução com IPTG $0,4 \mathrm{mM}$, nas temperaturas de 28 e $37{ }^{\circ} \mathrm{C} .15 \% \mathrm{~T}$. $\mathrm{M}$ - marcador de massa molecular em kDa (SDS - 6H, Sigma). 
temperatura menor, isto é, na cultura crescida a $28{ }^{\circ} \mathrm{C}$, quando comparada à cultura crescida a $37{ }^{\circ} \mathrm{C}$. Levando em consideração estes dados e os obtidos para os outros clones, optamos por efetuar a indução nas seguintes condições: $0,4 \mathrm{mM}$ do indutor, com posterior manutenção da cultura a $32{ }^{\circ} \mathrm{C}$ e extração das proteínas após 12 h de adição do indutor. Estas condições foram empregadas nos ensaios subseqüentes

\subsection{Expressão e purificação das proteínas heterólogas}

A produção das proteínas heterólogas foi efetuada com os clones selecionados no item anterior. Assim, para cada proteína de X. fastidiosa a ser estudada foi selecionado um clone bacteriano contendo o plasmídio de expressão com o gene de interesse. A extração das proteínas das células de E. coli foi efetuada através de ciclos de congelamento e descongelamento, como descrito no item 3.5.1.

Os clones produtores de proteínas com cauda de histidina ( $\mathrm{His}_{6}$ tag) foram utilizados para a purificação das proteínas heterólogas com o intuito de efetuarmos a caracterização enzimática. Inicialmente, utilizamos a amostra proteica proveniente da lise das células de E. coli como amostra para efetuarmos a cromatografia de afinidade em metal imobilizado (IMAC). Entretanto, diversas proteínas de E. coli ficaram adsorvidas à resina e foram eluídas juntamente com a proteína heteróloga (proteína de $X$. fastidiosa clonada no vetor de expressão). Observamos esta co-eluição testando as proteínas Xf - 810 (clone pNAW2) e Xf - 818 (clone pNAW4).

De forma a minimizar a presença das proteínas de E. coli nas etapas que empregam a cromatografia, foi efetuada a precipitação com sulfato de amônio. As proteínas obtidas a partir da lise de clone pNAW4 foram empregadas neste ensaio, visando a produção da proteína Xf - 818 com His 6 tag N-terminal. Na Figura 14 é mostrada a separação das proteínas em uma precipitação fracionada com sulfato de amônio e as respectivas atividades celulásicas das amostras e o perfil proteico após a eletroforese (SDS-

PAGE). Na Figura 15, o mesmo ensaio foi efetuado com as proteínas do clone pNAW6, para a produção da proteína Xf - 2708 com His 6 tag C-terminal. No 

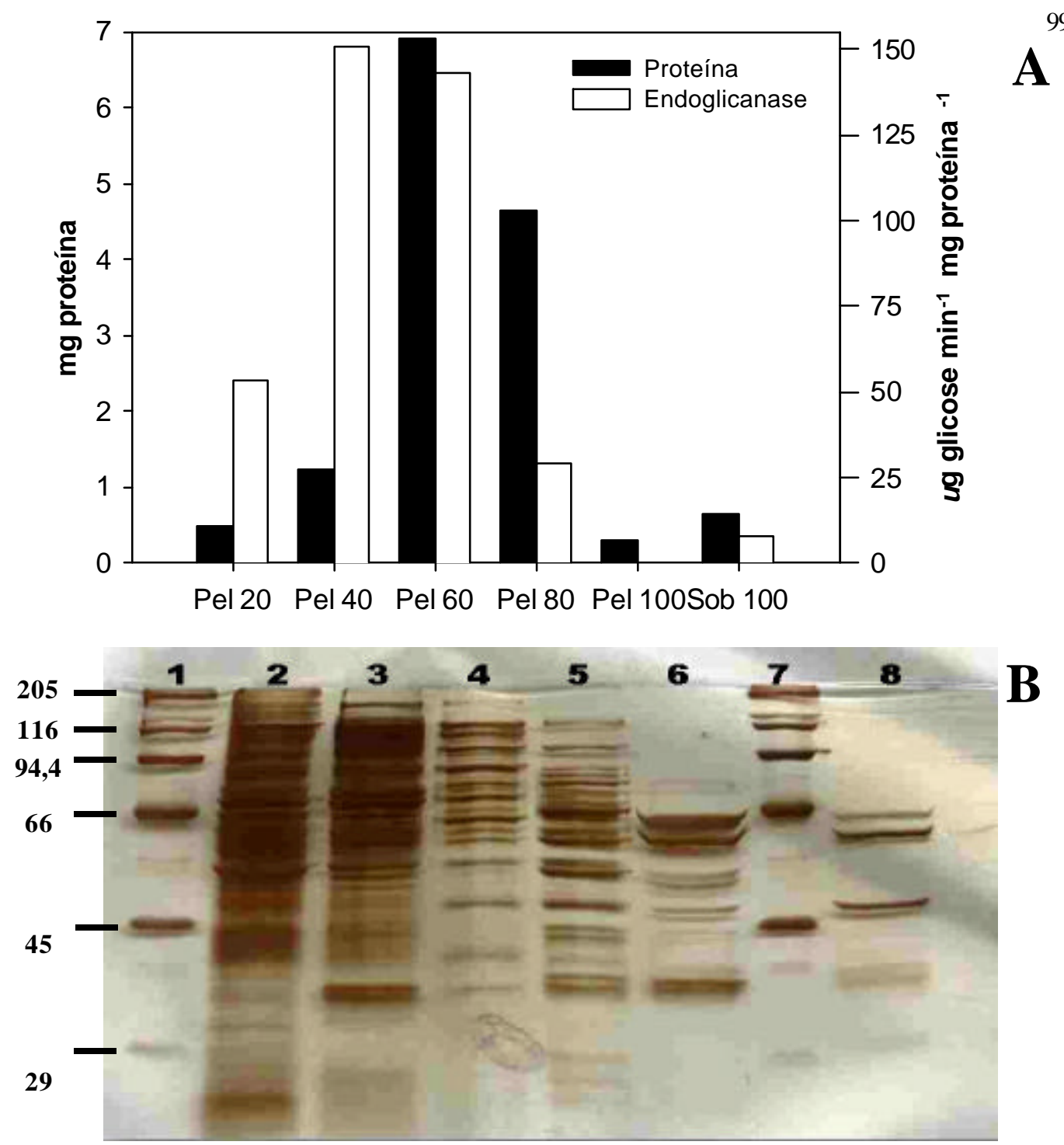

Figura 14 - A. Quantidade de proteína e atividade de celulase da proteína Xf - 818 presente nas amostras de precipitação fracionada com sulfato de amônio. As proteínas foram extraídas de células de $E$. coli contendo o plasmídio pNAW4 (Xf - 818 His 6 tag N-terminal) induzidas com IPTG 0,4 mM. A atividade celulásica específica foi efetuada em ensaio espectrofotométrico (item 3.4.1.2). Pel refere-se ao pelete na concentração de sulfato de amônio indicada. Sob é o sobrenadante após saturação completa. B. Eletroforese em gel desnaturante (SDS-PAGE) das proteínas presentes nas amostras acima. Linhas 1 e 7 - marcador de peso molecular $(\mathrm{kDa})$; Linha 2 - pelete da saturação a $20 \%$; Linha 3 - pelete da saturação a $40 \%$; Linha 4 - pelete da saturação a $60 \%$; Linha 5 - pelete da saturação a $80 \%$; Linha 6 pelete da saturação a $100 \%$; Linha 8 - sobrenadante da saturação a $100 \%$. Cada amostra consistiu de $2 \mu \mathrm{g}$ de proteínas, com exceção da amostra 8, que tinha $1 \mu \mathrm{g}$. 


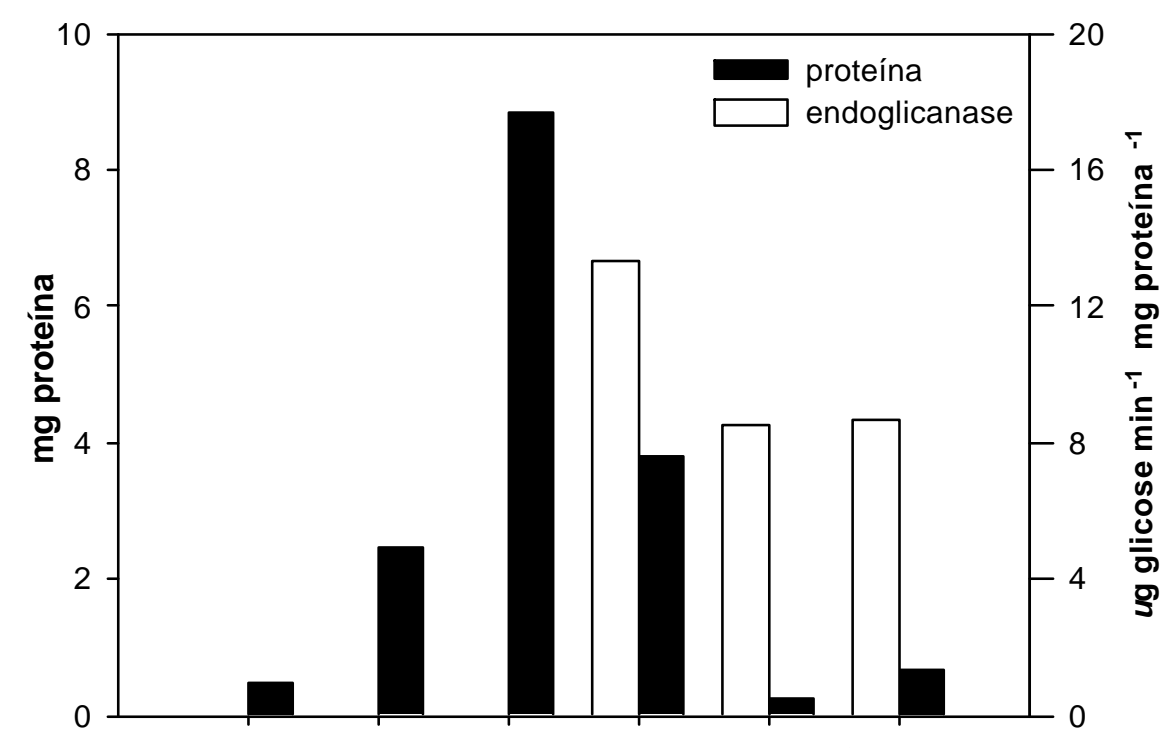

Pel 20 Pel $40 \quad$ Pel $60 \quad$ Pel 80 Pel 100 Sob 100

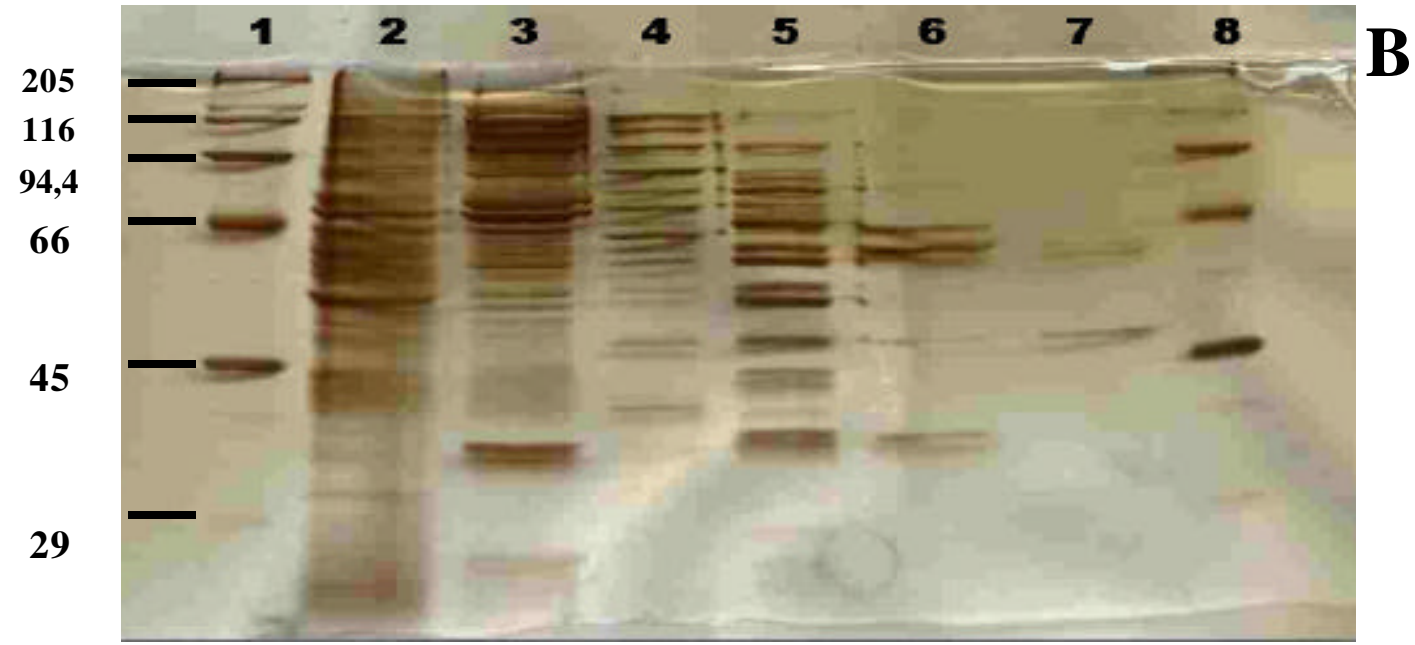

Figura 15 - A. Quantidade de proteína e atividade de celulase da proteína Xf - 2708 presente nas amostras de precipitação fracionada com sulfato de amônio. As proteínas foram extraídas de células de E. coli contendo o plasmídio pNAW6 (Xf - 2708 $\mathrm{His}_{6}$ tag C-terminal) induzidas com IPTG 0,4 mM. A atividade celulásica específica foi efetuada em ensaio espectrofotométrico (item 3.4.1.2). Pel refere-se ao pelete na concentração de sulfato de amônio indicada. Sob é o sobrenadante após saturação completa. B. Eletroforese em gel desnaturante (SDS-PAGE) das proteínas presentes nas amostras acima. Linhas 1 e 8 - marcador de peso molecular (kDa); Linha 2 - pelete da saturação a $20 \%$; Linha 3 - pelete da saturação a $40 \%$; Linha 4 - pelete da saturação a $60 \%$; Linha 5 - pelete da saturação a $80 \%$; Linha 6 - pelete da saturação a $100 \%$; Linha 7 - sobrenadante da saturação a $100 \%$. Cada amostra consistiu de $2 \mu \mathrm{g}$ de proteínas, com exceção da amostra 8 , que tinha $1 \mu \mathrm{g}$. 
caso da proteína Xf - 818, a maior parte da enzima precipita em concentrações de sulfato de amônio com 40 e 60 \% de saturação. Para a proteína Xf - 2708, a maior parte da atividade está presente nos precipitados a 80 e $100 \%$ de sulfato de amônio, com substancial parte da atividade presente ainda no sobrenadante após a saturação com sulfato de amônio. O perfil de proteínas separadas através de eletroforese desnaturante em gel de poliacrilamida permite comprovar que as proteínas maiores, ou agregados protéicos, tenderam a ficar localizados no precipitado de menor concentração de sulfato de amônio, ao passo que quanto maior a concentração do sal, progressivamente menor foi o tamanho das proteínas em solução.

Estas frações com alta atividade da enzima foram empregadas nos ensaios de otimização da cromatografia líquida em coluna.

Utilizando como base este primeiro ensaio, procedemos a precipitação em faixas maiores de sulfato de amônio. Para as proteínas Xf - 810 e Xf - 818 (massa molecular ao redor de 60 kDa), efetuamos a precipitação fracionada em 20 e $80 \%$ de saturação. Para a proteína Xf - 2708 (massa molecular de $39 \mathrm{kDa}$ ), empregamos a precipitação fracionada a 60 e $100 \%$ de saturação (Figura 16). Nas amostras dos clones que produzem a proteína Xf 818, a maior atividade específica foi observada no precipitado a $80 \%$ de saturação. Para as proteínas Xf - 810 e Xf - 2708 a maior atividade específica estava no sobrenadante da precipitação com sulfato de amônio.

De posse destas amostras provenientes da precipitação com sulfato de amônio, efetuamos diversas técnicas de cromatrografia líquida de coluna, com o objetivo de tentar purificar as proteínas heterólogas. Empregando as amostras da precipitação a 40, 60 e $80 \%$ de sulfato de amônio para Xf -818 e precipitados a 80 e $100 \%$ para Xf -2708 , foram efetuadas cromatografias de afinidade em metal em diversas condições, visando eliminar as proteínas de E. coli que estavam eluindo juntamente com as proteínas heterólogas recombinantes.

A cromatografia de afinidade foi inicialmente efetuada em tampão fosfato de sódio $20 \mathrm{mM} \mathrm{pH} \mathrm{7,2} \mathrm{com} \mathrm{NaCl}$ 0,5 M. O metal imobilizado foi o níquel, na forma de sulfato de níquel a 100 mM. Como o metal imobilizado apresenta capacidade de ligação e 
seletividade diferenciada, foram conduzidos testes com outros metais. No mesmo tampão utilizamos zinco (sulfato de zinco $100 \mathrm{mM}$ ). Neste ponto dos ensaios alteramos o tampão devido à precipitação de alguns metais em fosfato de sódio. Assim, empregamos tampão Tris$\mathrm{HCl} 50 \mathrm{mM} \mathrm{pH} \mathrm{7,5} \mathrm{NaCl}$ 0,5 M e os metais imobilizados foram zinco (sulfato de zinco 100 $\mathrm{mM}$ ), cobre (sulfato de cobre $100 \mathrm{mM}$ ) e cobalto (nitrato de cobalto $100 \mathrm{mM}$ ). O eluente foi imidazole a 500 mM no mesmo tampão. A mistura entre tampão sem e com imidazole foi feita gradualmente com o auxílio de um formador de gradiente.

Nestes testes, as proteínas recombinantes com $\mathrm{His}_{6}$ tag quando adsorvidas no metal imobilizado foram eluídas sempre com baixas quantidades de imidazole (ao redor de 20 $\mathrm{mM}$ ). Quando cobalto e cobre foram empregados com tampão Tris, as proteínas recombinantes sequer adsorveram à resina. No caso do zinco e do níquel, as proteínas foram eluídas na mesma concentração de imidazole. Estas amostras foram analisadas através de eletroforese para avaliação do grau de purificação atingido na etapa.

Como não foi possível a purificação das proteínas recombinantes em um único passo, via cromatografia de afinidade, empregamos cromatografia de troca aniônica e filtração em gel para aumentar a possibilidade de purificação das proteínas.

As proteínas Xf - 818 e Xf - 2708 não apresentaram afinidade pela resina trocadora de ânions High Q (Bio-Rad), quando a cromatografia foi efetuada em tampão fosfato de sódio $50 \mathrm{mM}$ pH 7,2. Entretanto, uma grande quantidade de proteína de E. coli ficou adsorvida nesta resina e foi eluída com $\mathrm{NaCl}$ no mesmo tampão (Figura 17). Quando efetuamos cromatografia em troca catiônica (High S - Bio-Rad), com tampão acetato de sódio $50 \mathrm{mM}$ pH 5,2 ou tampão fosfato de sódio $50 \mathrm{mM} \mathrm{pH} \mathrm{7,2} \mathrm{não} \mathrm{houve} \mathrm{proteínas} \mathrm{adsorvidas} \mathrm{à}$ resina.

No caso da proteína $\mathrm{Xf}-818$, utilizamos a amostra que não adsorveu à resina de troca aniônica para aplicá-la na cromatografia de afinidade em metal imobilizado. Esta amostra foi separada na fração que não apresentou afinidade pela resina de afinidade e na que apresenta afinidade pela resina e é eluída com a adição de imidazole. Na fração adsorvida ficou retida a maior parte da proteína Xf -818 , com atividade CMCásica (Figura 18). As 
frações com atividade de celulase foram reunidas e submetidas à separação de acordo com o tamanho da molécula em cromatografia de exclusão molecular (Figura 19).

Esta seqüência de cromatografias de troca aniônica, afinidade em metal e exclusão molecular, representa um protocolo que permite a purificação da proteína Xf -818 (Figura 20), mantendo sua atividade de CMCase.

No caso das outras proteínas, a cromatografia de afinidade em metal imobilizado também não foi eficiente na purificação da proteína recombinante. $\mathrm{O}$ mesmo protocolo empregado na purificação da Xf - 818 pode ser aplicado a estas proteínas, entretanto, o comportamento de cada proteína é peculiar em cada cromatografia e assim, não houve tempo hábil no estabelecimento de um protocolo para a purificação das outras proteínas.

\subsection{Atividade enzimática}

Os genes que apresentam homologia de sequiência com celulases, Xf - 810, Xf - 818 e Xf - 2708, foram clonados, expressos em E. coli e através de ensaios enzimáticos foi confirmado experimentalmente que as proteínas codificadas por estes genes apresentam atividade celulásica (endoglicanase). Desta forma, estas proteínas podem ser classificadas como endoglicanases EC 3.2.1.4, cujo código enzimático identifica as celulases com atividade endoglicolítica.

Partindo do pressuposto de que os genes Xf -810 , Xf -818 e Xf -2708 produzam endoglicases (CMCases), efetuamos a caracterização dos parâmetros ótimos para esta atividade. Esta condição, usualmente conhecida como valor de pH do meio, foi avaliada pela atividade sobre o substrato CMC dissolvido em tampões variando em composição referente ao íon tamponante entre os valores de $\mathrm{pH}$ 2,6 a 8,0. Analisando as três enzimas em conjunto observamos que a hidrólise de CMC é melhor efetuada em pH ácido, entre valores 5 a 5,6 (Figura 21). As celulases Xf -810 e Xf -818 apresentaram 


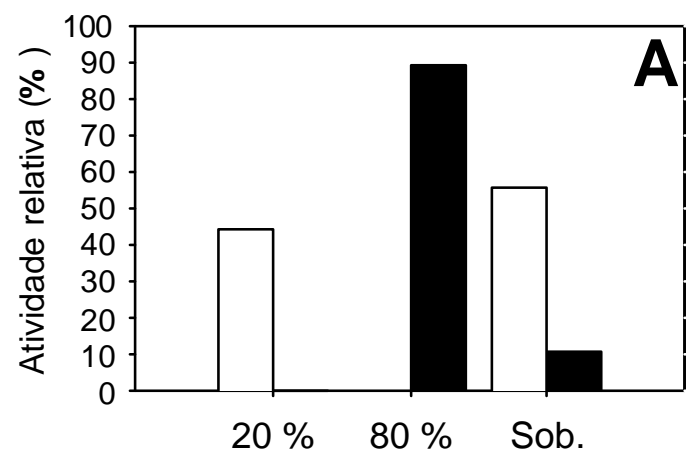

Proteína Endoglicanase
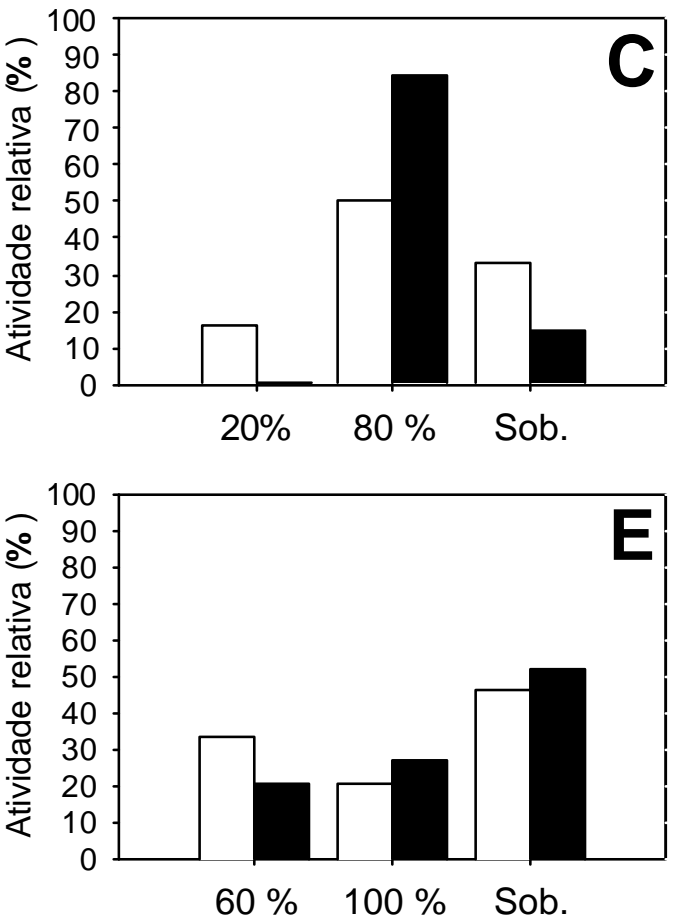

Figura 16 - Quantidade de proteína e atividade de celulase (carboidratos redutores liberados por mg de proteína min), expressas em porcentagem do total, presente nas amostras de precipitação fracionada com sulfato de amônio. Lisado de células de E. coli contendo os seguintes plasmídios foram usados como fonte de enzimas: A (Xf - 810 His $_{6}$ tag N-; pNAW2), B (Xf - 818 His $_{6}$ tag N-; pNAW4), C (Xf 818 nativa; pNAW3), D (Xf - 2708 His $_{6}$ tag C-; pNAW6) and $\mathbf{E}(\mathrm{Xf}-2708$ nativa; pNAW5). 


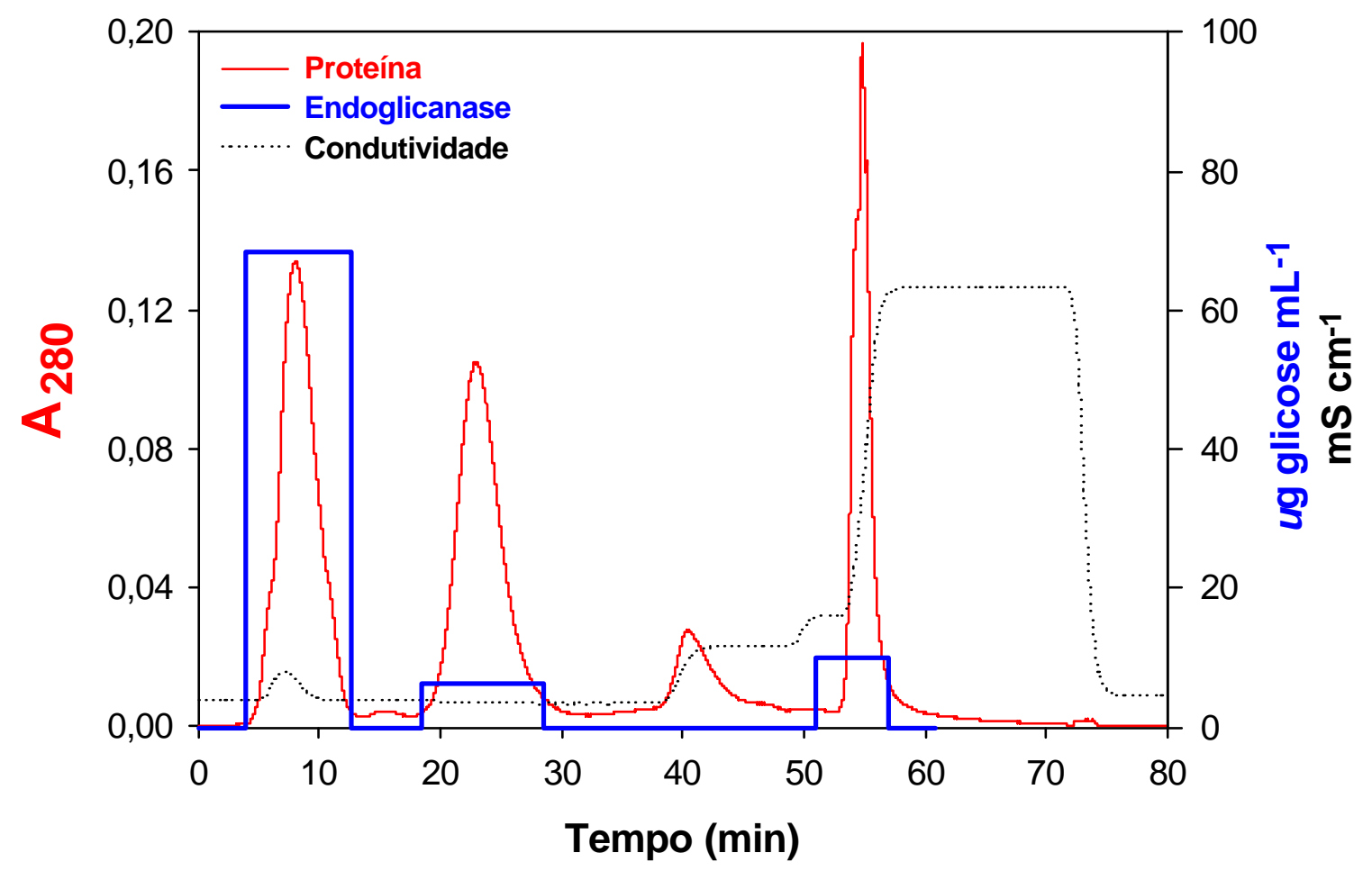

Figura 17 - Cromatografia de troca iônica das proteínas do clone de E. coli BL21(DE3)pLysS contendo o plasmídio pNAW4, expressando a endoglicanase Xf - 818 ( His $_{6}$ tag $\mathrm{N}$-terminal). A amostra foi concentrada com sulfato de amônio e separada em resina trocadora aniônica High-Q (Bio-Rad) equilibrada com tampão fosfato de sódio $20 \mathrm{mM} \mathrm{pH} \mathrm{7,2} \mathrm{e} \mathrm{eluída} \mathrm{no} \mathrm{mesmo} \mathrm{tampão} \mathrm{com}$ $\mathrm{NaCl}$ 0,5 M. A amostra contendo $10 \mathrm{mg}$ de proteína foi aplicada em fluxo de 1 $\mathrm{mL} \min ^{-1}$ (1 a $10 \mathrm{~min}$ ) e a eluição foi efetuada a $2 \mathrm{~mL} \mathrm{~min}^{-1}$ (10 a $80 \mathrm{~min}$ ). As frações coletadas ( 2 min cada) foram reunidas de acordo com o perfil de eluição das proteínas e avaliadas quanto a atividade celulásica (3.4.1.2). A atividade de endoglicanase está representada como glicose liberada. 


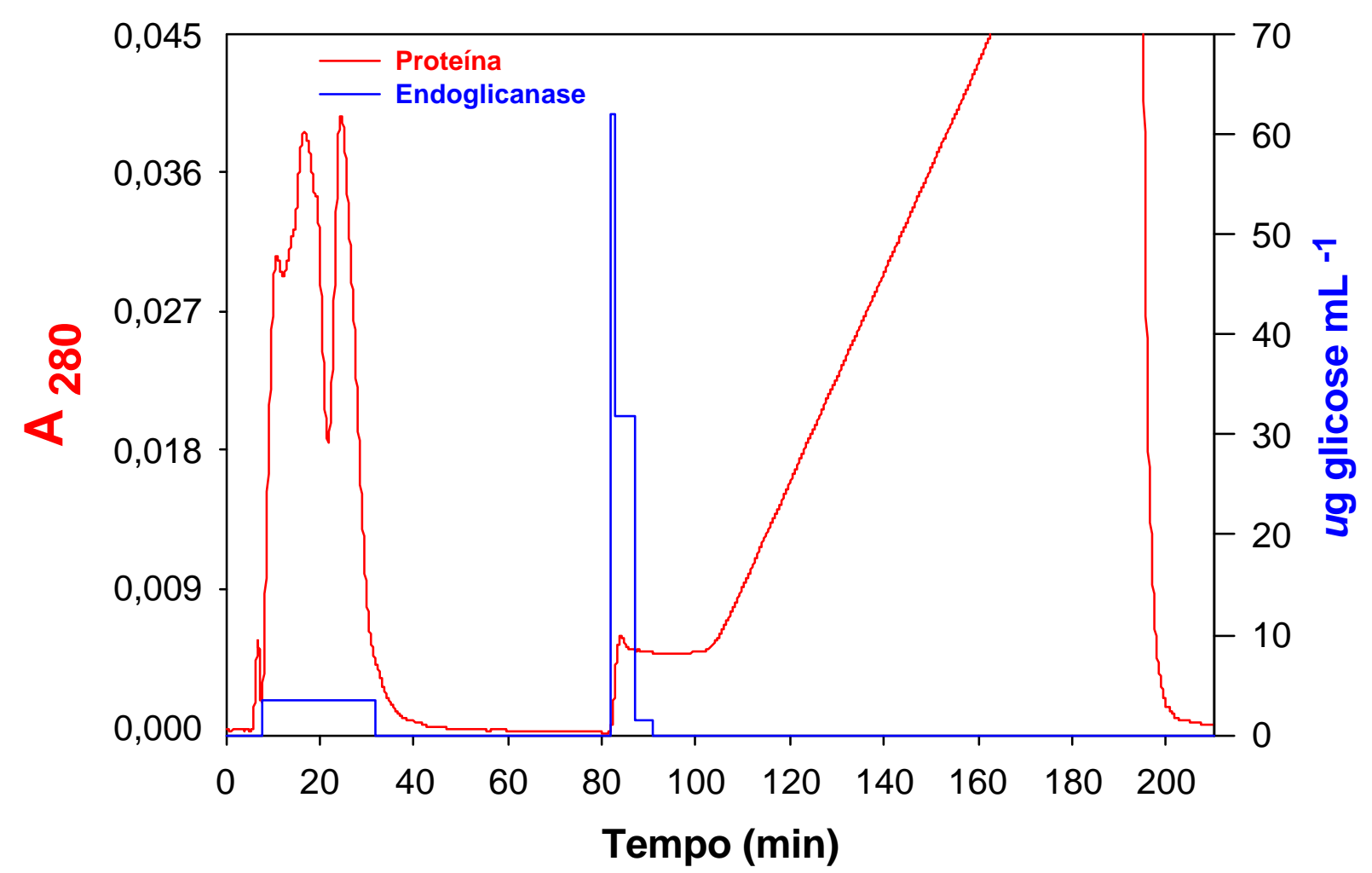

Figura 18 - Cromatografia de afinidade em metal imobilizado (IMAC) das proteínas não adsorvidas na resina trocadora aniônica e que apresentaram atividade celulásica (eluídas entre os minutos 5 a 13 do gráfico apresentado na Figura 17). A amostra foi aplicada em tampão fosfato de sódio $20 \mathrm{mM} \mathrm{pH} \mathrm{7,2} \mathrm{NaCl}$ 0,5 M a fluxo de $0,5 \mathrm{~mL} \mathrm{~min}^{-1} \mathrm{e}$ as proteínas ligadas foram eluídas no mesmo tampão com imidazole $0,5 \mathrm{M}$ a $1 \mathrm{~mL} \min ^{-1}$. As frações coletadas (2 min cada fração) foram reunidas de acordo com o perfil de eluição e avaliadas quanto a atividade celulásica (3.4.1.2). Observar que o imidazol contribui para a absorbância a 280 nm. A atividade de endoglicanase está representada como glicose liberada. 


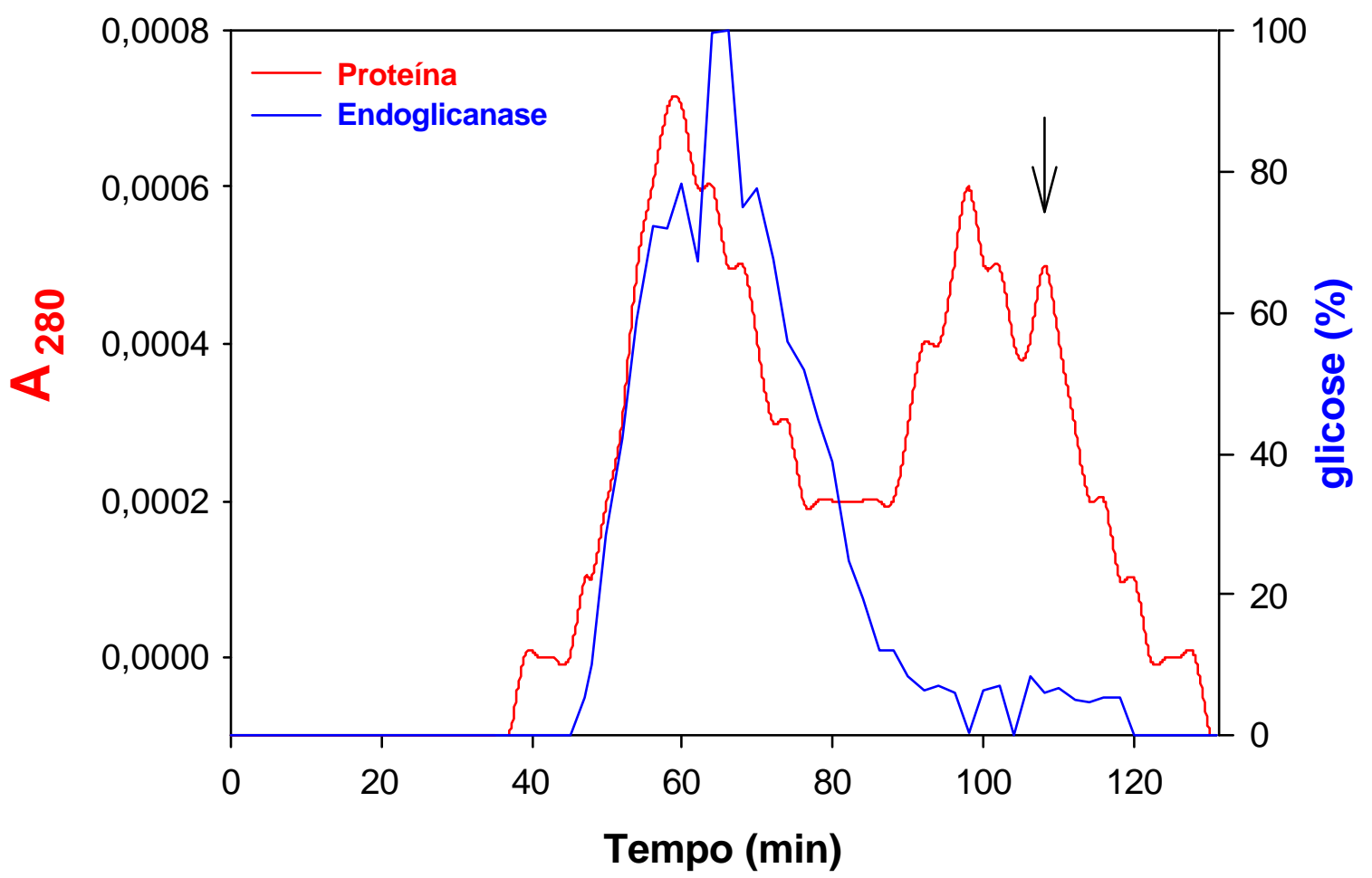

Figura 19 - Cromatografia de exclusão molecular (Sephacryl S100HR) das proteínas que ficaram ligadas na resina de afinidade em metal (frações com atividade celulásica da Figura 18). A amostra foi aplicada em tampão acetato de sódio - ácido acético $50 \mathrm{mM}$ pH 5,2 em fluxo de 0,5 mL $\mathrm{min}^{-1}$. Frações de $2 \mathrm{~mL}$ foram coletadas e avaliadas quanto a atividade celulásica (3.4.1.2). A seta indica o ponto de eluição do imidazol, presente no tampão de eluição da IMAC. A atividade de endoglicanase está expressa em porcentagem de glicose liberada. 


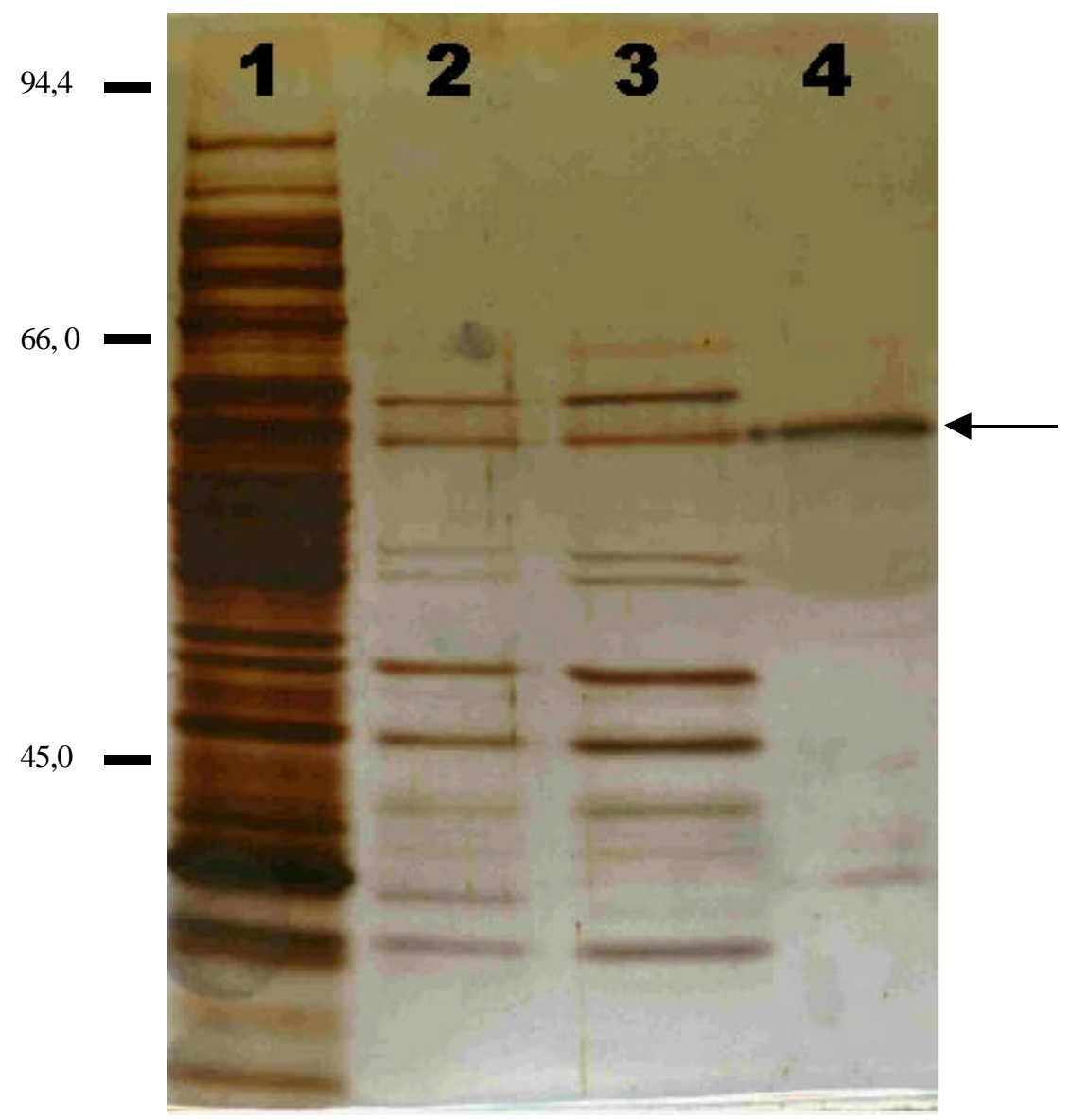

Figura 20 - Eletroforese em gel desnaturante (SDS-PAGE) das proteínas presentes nas etapas de purificação da proteína Xf -818 . O lisado de E. coli, contendo o plasmídio pNAW4 (Xf - 818 His $_{6}$ tag N-terminal), foi empregado como fonte de proteínas. Linha 1 - pelete da saturação a $80 \%$ de sulfato de amônio; amostra aplicada na cromatografia de troca aniônica; Linha 2 - amostra não ligada na resina de troca aniônica (frações 5 a 13 min da Figura 17) ; Linha 3 - fração não ligada na coluna de afinidade em metal (frações 8 a 35 min da Figura 18); Linha 4 - fração ligada na coluna de afinidade e eluída com 20 mM de imidazole (frações 83 a 90 min da Figura 18), representano a proteína Xf - 818 purificada. A seta indica a posição de Xf - 818 e os marcadores de massa molecular em kDa estão indicados. 

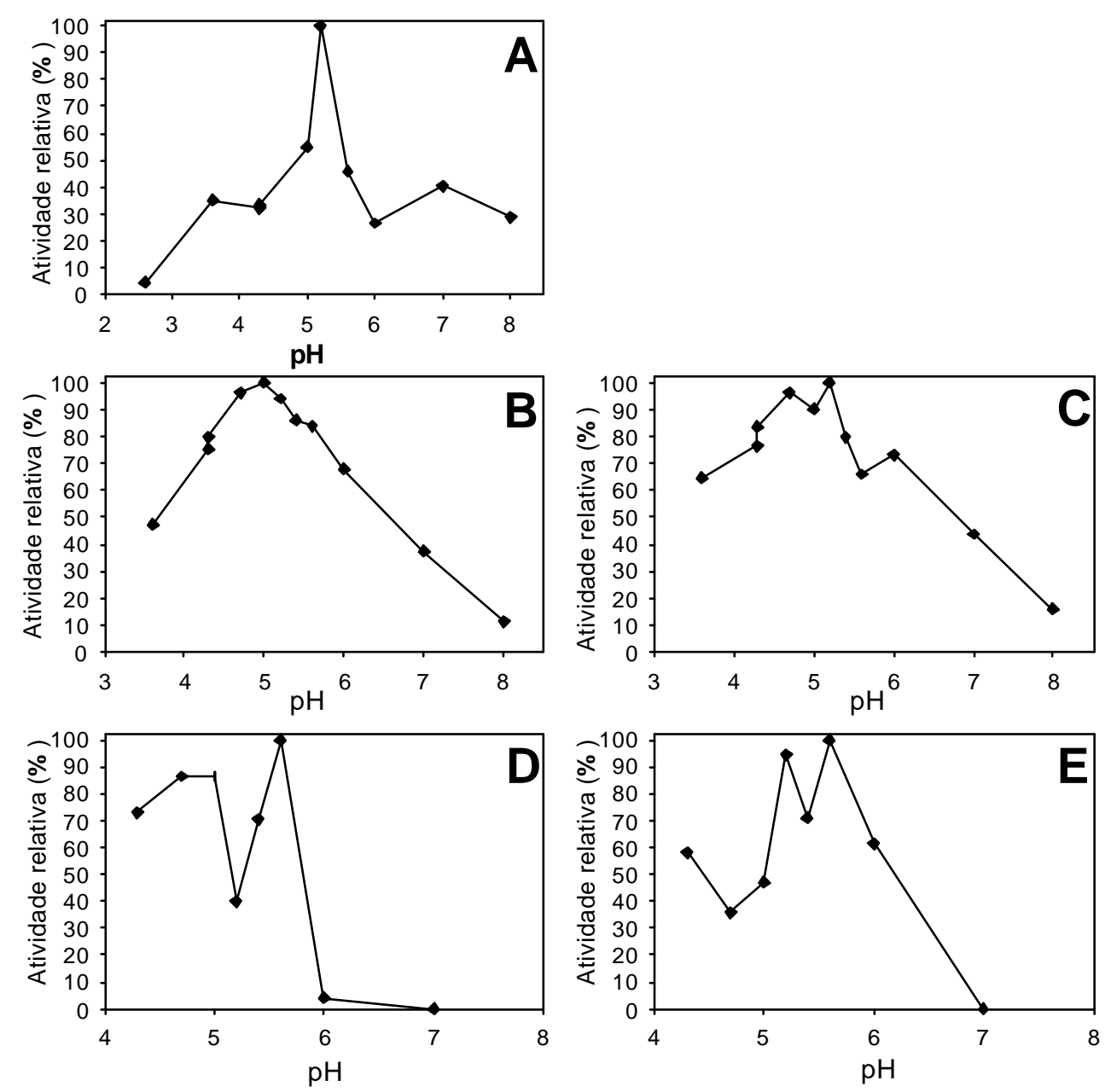

Figura 21 - Atividade celulásica (carboidratos redutores liberados por mg de proteína por min) sob variação de $\mathrm{pH}$ das celulases de $X$. fastidiosa expressas em termos relativos. As fontes de enzima foram: $\mathbf{A}\left(\mathrm{Xf}-810 \mathrm{His}_{6}\right.$ tag N-; pNAW2), B $\mathrm{Xf}$ - 818 His $_{6}$ tag N-; pNAW4), C (Xf - 818 nativa; pNAW3), D (Xf - 2708 His $_{6}$ tag C-; pNAW6) e E (Xf - 2708 nativa; pNAW5). O substrato CMC foi dissolvido a $1 \%(\mathrm{~m} / \mathrm{v})$ nos seguintes tampões a $50 \mathrm{mM}$ : ácido cítrico - citrato de sódio em pH 2,6 - 3,0 - 3,6 - 4,3 - 5,4; ácido acético - acetato de sódio em pH 4,3 - 4,7 - 5,0 - 5,2 - 5,6; fosfato de sódio em pH 6,0 - 7,0 - 8,0. A reação consistiu de $50 \mu \mathrm{L}$ de cada preparação enzimática e $200 \mu \mathrm{L}$ do substrato $\mathrm{CMC}$, totalizando $250 \mu \mathrm{L}$. Este volume foi mantido a $40{ }^{\circ} \mathrm{C}$ durante $120 \mathrm{~min}$, sendo posteriormente os carboidratos redutores formados quantificados (Lever, 1972). Para cada ponto foram efetuadas três avaliações. 
maior atividade catalítica em pH 5,2 e a celulases Xf - 2708 em pH 5,6 no tampão acetato de sódio.

A força iônica do ambiente também pode influenciar a atividade catalítica e observamos isto incubando a enzima no melhor valor de $\mathrm{pH}$ para a hidrólise em tampão com variação de molaridade entre 20 e 200 mM da concentração do íon tamponante (Figura 22).

A catálise enzimática apresenta uma certa linearidade em função do tempo e da temperatura em que está sendo feito o ensaio. O tempo neste caso pode influenciar a estabilidade enzimática, bem como a parcela de substrato disponível para a enzima. Este fator foi avaliado incubando-se a enzima com o substrato por até $18 \mathrm{~h}$ a $40{ }^{\circ} \mathrm{C}$ (Figura 23). Percebemos que quanto maior o período de incubação, maior é a quantidade de açúcares liberados. Observamos diferenças entre as enzimas. No caso de Xf -818 , a catálise é exatamente linear até $4 \mathrm{~h}$ de incubação, tendendo à saturação após este período. $\mathrm{O}$ comportamento com maior variação foi exibido pela Xf - 2708, o qual é baixo até a primeira hora, aumentando até o final da segunda hora de incubação, apresentando somente um leve incremento nas qeatro horas adicionais. Desta maneira, esta enzima parece apresentar a menor estabilidade nas condições do ensaio empregado. Entretanto, a enzima Xf - 2708 quintuplicou a liberação de açúcares redutores com 18 h de incubação em relação à sexta hora de incubação, um valor intermediário entre Xf - 810 (que no mesmo período aumentou este valor cerca de 20 vezes) e Xf - 818 (apenas dobrou a quantidade de açúcares liberados).

A influência da temperatura na hidrólise da CMC foi avaliada incubando-se ambos em temperaturas variáveis de 4 a $80{ }^{\circ} \mathrm{C}$ durante 1 h (Figura 24). Embora a relação temperatura versus atividade enzimática não tenha apresentado uma curva característica para Xf -810 e Xf - 2708, mas sim para Xf - 818, todas enzimas apresentaram a maior capacidade de liberar açúcares redutores a $65^{\circ} \mathrm{C}$. Acima de $65^{\circ} \mathrm{C}$, a atividade decresceu com o aumento da temperatura, sendo relativamente alta a $70{ }^{\circ} \mathrm{C}$ e praticamente inexistente a $80{ }^{\circ} \mathrm{C}$, de uma maneira uniforme, para todas enzimas. 
Em todos os casos, as proteínas recombinantes e nativas apresentaram perfis muito similares (em se tratando de Xf -818 e Xf - 2708), donde podemos sugerir que a cauda de hexahistidinas não esteja interferindo na atividade enzimática. Cabe ressaltar que CMC foi incubada nas mesmas condições e não houve liberação não enzimática de açúcares redutores em quantidades apreciáveis.

A sinergia não foi observada quando incubamos as enzimas Xf - 810, Xf 818 e Xf - 2708 em todas as combinações possíveis (Tabela 11). Pelo contrário, o que observamos foi a menor atividade da enzima Xf -818 , a mais ativa neste ensaio. Por exemplo, a enzima Xf - 818 liberou 5,5 $\mu \mathrm{g}$ de carboidratos redutores da $\mathrm{CMC}$, enquanto que juntamente com Xf - 810, Xf - 2708 ou ambas, este valor não foi atingido, aparentemente indicando uma inibição da liberação de carboidratos redutores.

Observando a degradação da celulose cristalina, na forma de Avicel ou celulose amolecida com ácido (Figura 25), a enzima Xf - 810 é a que produz a maior quantidade de açúcares redutores comparativamente a Xf - 818 e Xf - 2708 na hidrólise de Avicel. Quando a celulose cristalina foi previamente tratada com ácido (Figura 25), inicialmente a hidrólise por Xf - 810 é maior, mas após 18,5 h de incubação, a proteína Xf 818 hidrolisa substancialmente mais este polímero. A enzima Xf - 2708 hidrolisa Avicel praticamente na mesma extensão que Xf - 818 e não hidrolisa a celulose amolecida. A melhor caracterização enzimática tendo celulose microcristalina como substrato pode ser acompanhada se os produtos da hidrólise forem analisados qualitativamente. A degradação de celulose com a produção de celobiose é uma característica das celobiohidrolases (mecanismo exohidrolítico). Esta avaliação foi efetuada empregando-se as mesmas amostras acima descritas, em análise através de cromatrografia de camada delgada. Entretanto, não foi possível detectar a formação de celooligossacarídeos pela hidrólise de Avicel ou celulose amolecida pela ação de Xf - 810, Xf - 818 e Xf - 2708, nestas condições. Em ensaio idêntico, efetuado com $111 \mathrm{U}$ da enzima Xf - 818 (Figura 26), foi possível evidenciar a produção de celobiose e celotriose pela hidrólise de Avicel e celulose amolecida com ácido 
(Figura 27). A quantidade de oligossacarídeos formados foi maior na hidrólise de celulose amolecida do que na hidrólise de Avicel.

Uma possibilidade para a redundância de enzimas com a mesma função, como as celulases, é que elas apresentem especificidades diferentes de acordo com o substrato. Isto pode ser comprovado no caso das celulases de $X$. fastidiosa pela hidrólise de diferentes polímeros, como apresentado acima. Outra variação que foi analisada é a capacidade de hidrolisar oligossacarídeos como a celobiose[G2], celotriose[G3], celotetraose[G4] e celopentaose[G5], entre outros. Novamente, a enzima Xf - 818 produziu resultado positivo, sendo capaz de degradar celotetraose e celopentaose (Figura 27). Nos ensaios com Xf 810 e Xf - 2708 não foi evidenciada a degradação dos oligossacarídeos.

Uma das análises que mais caracteriza as enzimas é a gama de substratos hidrolisados. Avaliamos a atividade hidrolítica sobre substratos formados por unidades repetitivas de glicose (com ligações $\beta-1,4$ ou $\beta$-1,3) ou xilose (com ligações $\beta$-1,4) na sua cadeia principal, pois estes são os substratos característicos das celulases. A enzima Xf - 818 é, entre as três celulases caracterizadas, a que hidrolisa a maior diversidade de substratos estudados, liberando açúcares redutores a partir de CMC, de celulose microcristalina, de celulose amolecida com ácido, e de xilana (Tabela 12). Esta enzima, e a proteína Xf - 2708 hidrolisam a xilana "Oatspels", enquanto todas hidrolisam a xilana "Birchwood". Entretanto, Xf - 2708 não hidrolisa celulose amolecida com ácido, o que é catalisado pela Xf -818 (Figura 26). Xf - 810 não hidrolisa xilana "Oatspels" mas é a enzima que mais rapidamente hidrolisa a celulose microcristalina e celulose tratada com ácido. Estas três enzimas não hidrolisam $\alpha$-celulose (celulose altamente cristalina), goma xantana (exopolissacarídeo bacteriano, com cadeia principal constituída de pentâmeros com celobiose na estrutura principal) ou laminarina. A laminarina, um polímero composto de glicose unida através de ligações $\beta-1,3$, foi incluída pois algumas celulases apresentam a capacidade de hidrolisar esta ligação. Comparativamente, as atividades de cada enzima diferem e a importância dessa 
especificidade ou preferência será discutida no próximo capítulo, juntamente com os outros resultados.

Avaliamos também a capacidade das enzimas Xf - 810, Xf - 818 e Xf - 2708 ligarem-se à celulose microcristalina. Como esperado, somente a Xf -818 possui esta capacidade, provavelmente devido à presença de um domínio ligador de celulose (DLC ou MLC do tipo II) na extremidade C-terminal desta enzima. Podemos observar na Figura 28 que a Avicel incorporada com Xf - 818 apresentou atividade de celulase mesmo após retirada das proteína não ligadas. A importância deste fato na catálise enzimática também será discutido adiante. Nas amostras incubadas com as enzimas Xf -810 e Xf -2708 não observamos esta atividade de celulase. 

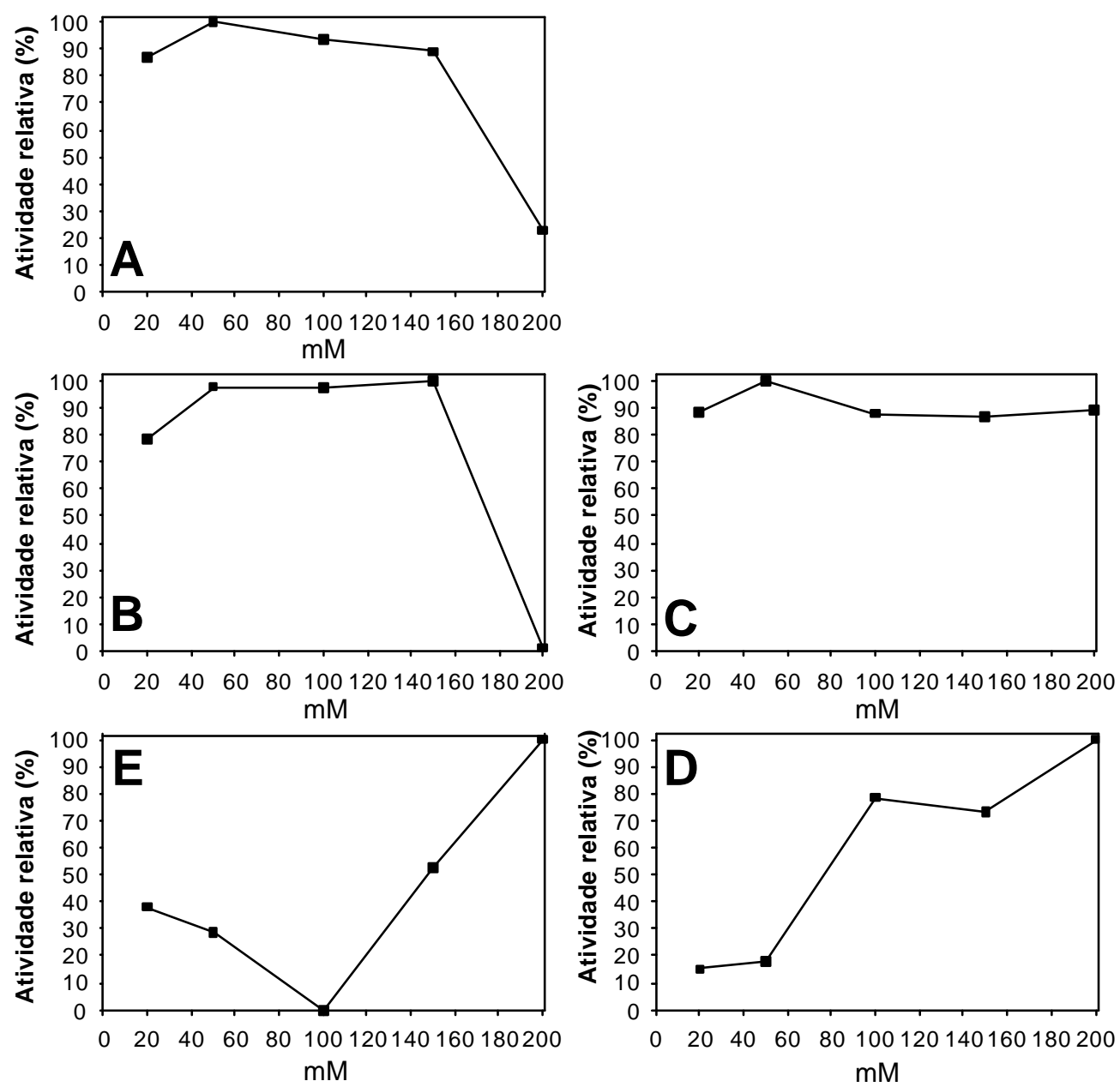

Figura 22 - Atividade celulásica (carboidratos redutores liberados por mg de proteína por min) sob variação de molaridade das celulases de $X$. fastidiosa expressas em termos relativos. As fontes de enzima foram: $\mathbf{A}\left(\mathrm{Xf}-810 \mathrm{His}_{6}\right.$ tag N-; pNAW2), B (Xf - 818 His $_{6}$ tag $\mathrm{N}-$; pNAW4), C (Xf - 818 nativa; pNAW3), D (Xf 2708 His $_{6}$ tag C-; pNAW6) e $\mathbf{E}(\mathrm{Xf}-2708$ nativa; pNAW5). O substrato CMC foi dissolvido a $1 \%(\mathrm{~m} / \mathrm{v})$ no tampão ácido acético - acetato de sódio $\mathrm{pH}$ 5,2 nas molaridades 20, 50, 100, 150 e $200 \mathrm{mM}$. A reação consistiu de $50 \mu \mathrm{L}$ de cada preparação enzimática e $200 \mu \mathrm{L}$ do substrato $\mathrm{CMC}$, totalizando $250 \mu \mathrm{L}$. Este volume foi mantido a $40{ }^{\circ} \mathrm{C}$ durante $120 \mathrm{~min}$, sendo posteriormente os carboidratos redutores formados quantificados (Lever, 1972). Para cada ponto foram efetuadas três avaliações. 

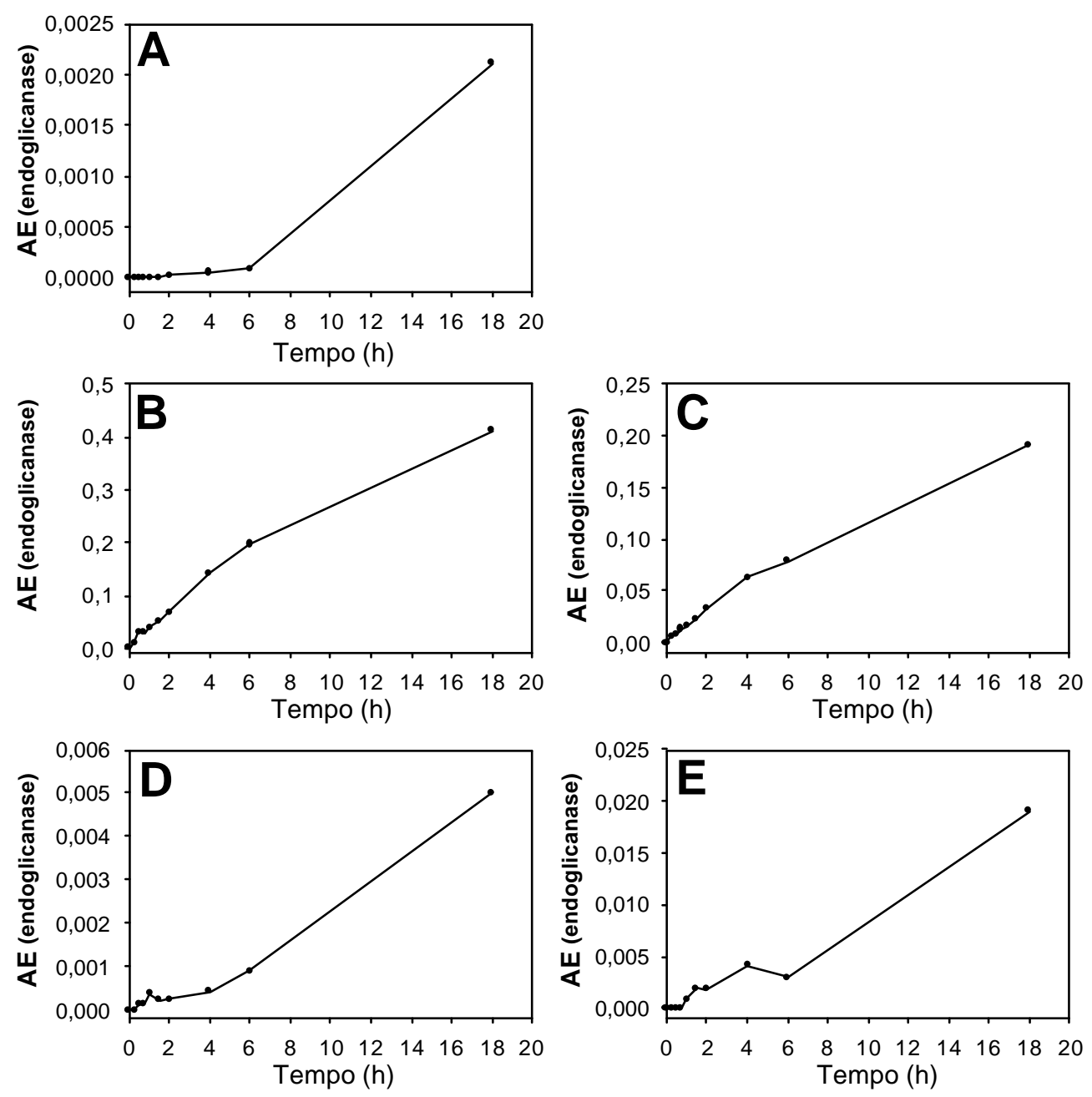

Figura 23 - Atividade celulásica específica - AE (carboidratos redutores liberados por mg de proteína por $\min ^{-1}$ ) em relação ao tempo de incubação das celulases de $X$. fastidiosa. As fontes de enzima foram: A (Xf - $810 \mathrm{His}_{6} \operatorname{tag} \mathrm{N}-;$ pNAW2), B (Xf - 818 His $_{6}$ tag $\mathrm{N}$; pNAW4), C (Xf - 818 nativa; pNAW3), D (Xf - 2708 $\mathrm{His}_{6}$ tag C-; pNAW6) e E (Xf - 2708 nativa; pNAW5). O substrato CMC foi dissolvido em tampão ácido acético - acetato de sódio $50 \mathrm{mM} \mathrm{pH} \mathrm{5,2} \mathrm{a} 1 \%$ $(\mathrm{m} / \mathrm{v})$ nos ensaios para Xf - 810 e Xf - 818 e no mesmo tampão a $200 \mathrm{mM}$ para $\mathrm{Xf}-2708$. A reação consistiu de $50 \mu \mathrm{L}$ de cada preparação enzimática e 200 $\mu \mathrm{L}$ do substrato $\mathrm{CMC}$, totalizando $250 \mu \mathrm{L}$. Este volume foi mantido a $40{ }^{\circ} \mathrm{C}$ durante $15 \mathrm{~min}, 30 \mathrm{~min}, 45 \mathrm{~min}, 60 \mathrm{~min}, 90 \mathrm{~min}, 2$ h, 4 h, 6h e 18 h. Após este período, os carboidratos redutores formados foram quantificados (Lever, 1972). Para cada ponto foram efetuadas três avaliações. 

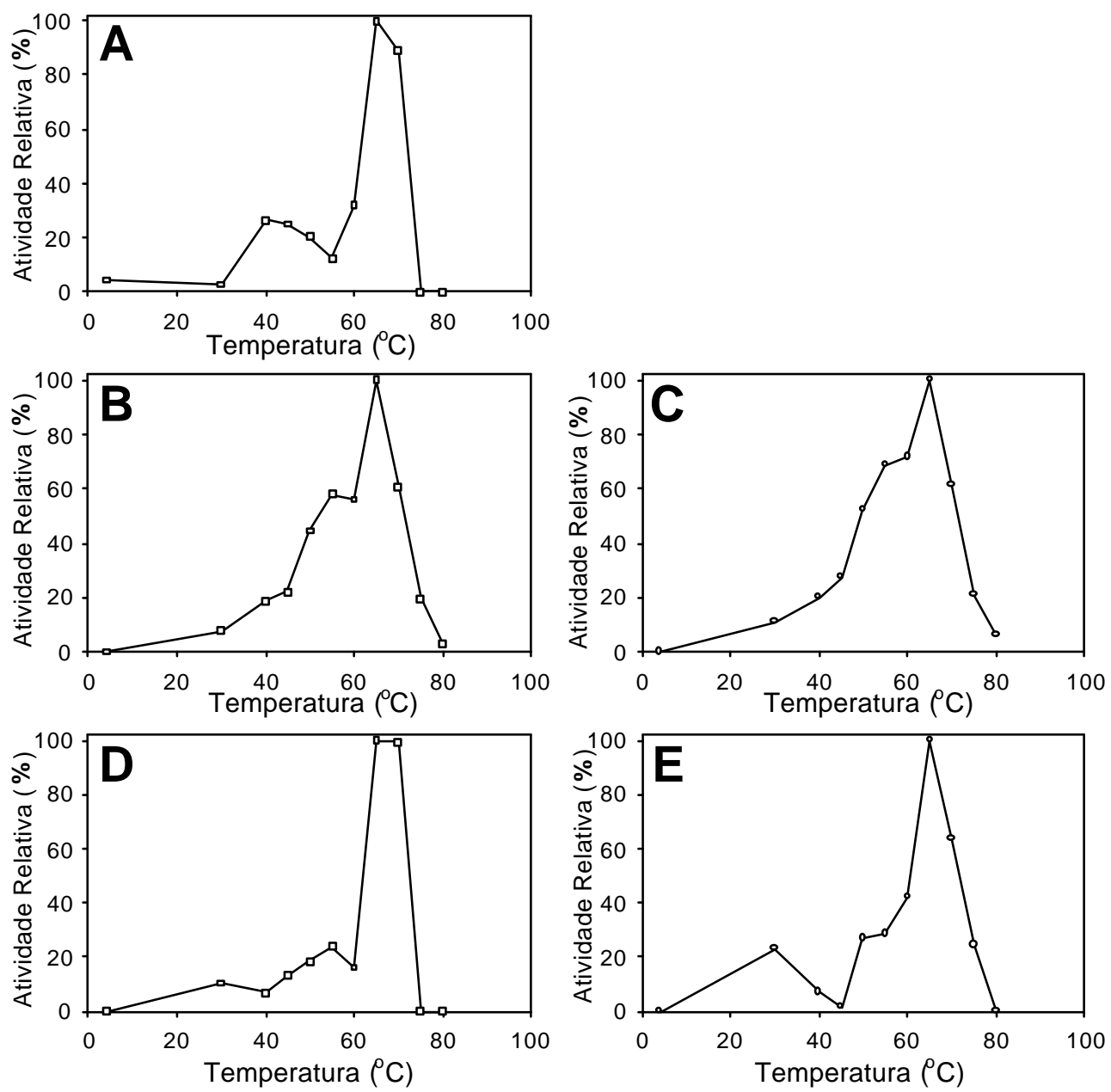

Figura 24 - Atividade celulásica (carboidratos redutores liberados por mg de proteína por min) em relação a temperaturas de incubação das celulases de $X$. fastidiosa, em termos relativos. As fontes de enzima foram: $\mathbf{A}\left(\mathrm{Xf}-810 \mathrm{His}_{6}\right.$ tag N-; pNAW2), B (Xf - 818 His $_{6}$ tag $\mathrm{N}-$; pNAW4), C (Xf - 818 nativa; pNAW3), D (Xf 2708 His $_{6}$ tag C-; pNAW6) e E (Xf - 2708 nativa; pNAW5). O substrato CMC foi dissolvido em tampão ácido acético - acetato de sódio $50 \mathrm{mM} \mathrm{pH} \mathrm{5,2}$ a $1 \%(\mathrm{~m} / \mathrm{v})$ nos ensaios para Xf - 810 e Xf - 818 e no mesmo tampão a 200 $\mathrm{mM}$ para Xf - 2708. A reação consistiu de $50 \mu \mathrm{L}$ de cada preparação enzimática e $200 \mu \mathrm{L}$ do substrato $\mathrm{CMC}$, totalizando $250 \mu \mathrm{L}$. Este volume foi mantido durante $1 \mathrm{~h}$ nas temperaturas de 4, 20, 25, 30, 35, 40, 45, 50, 55, 60, $65,70,75$ e $80{ }^{\circ} \mathrm{C}$. Após este período, os carboidratos redutores formados foram quantificados (Lever, 1972). Para cada ponto foram efetuadas três avaliações. 


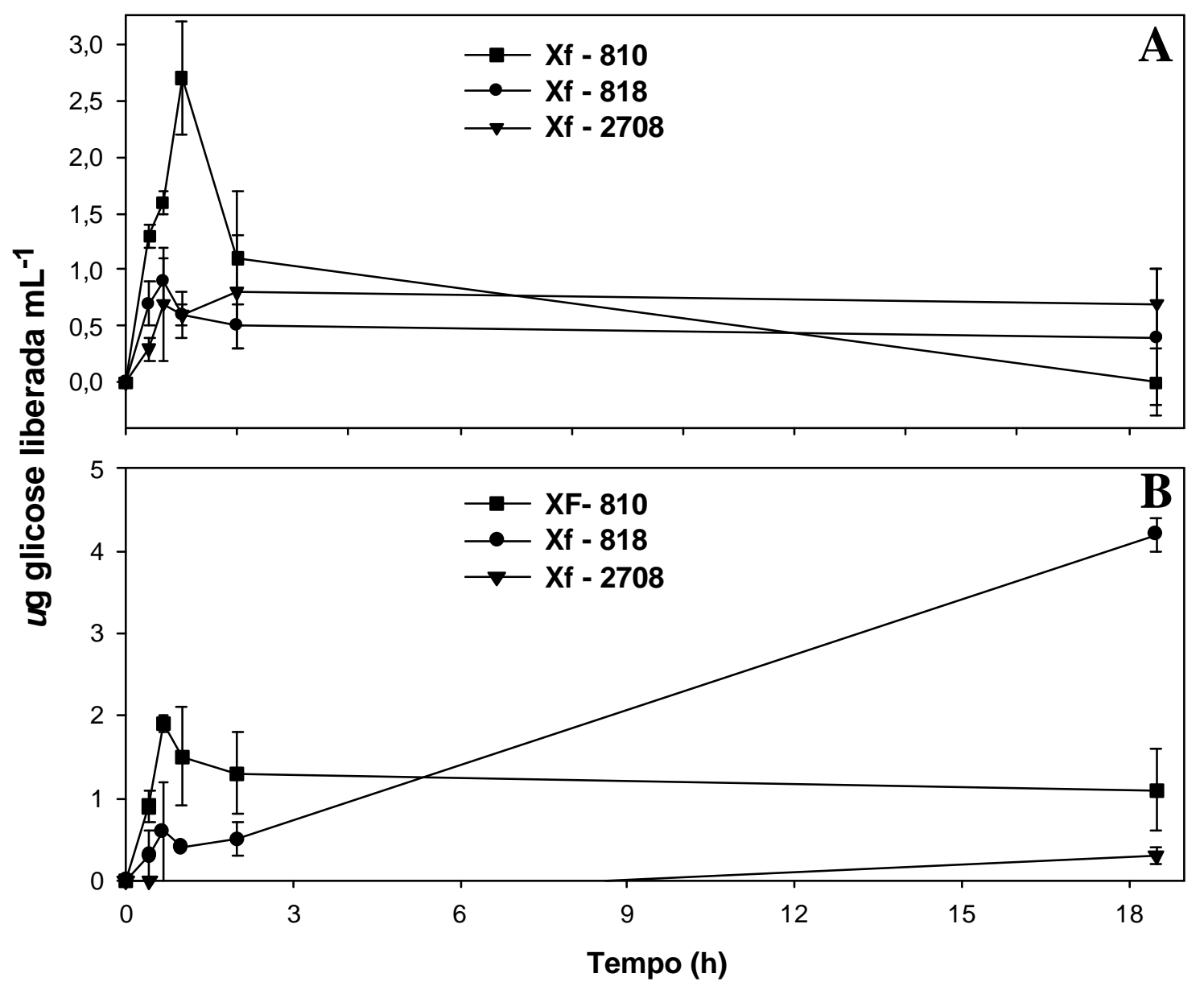

Xf-810 (nativa - pNAW1), Xf-818 (nativa - pNAW3) e Xf-2708 nativa; pNAW5). Os substratos foram preparados a $1 \%(\mathrm{~m} / \mathrm{v})$ em tampão acetato de sódio - ácido acético $50 \mathrm{mM}$ pH 5,2. A reação foi mantida pelo tempo indicado a $65{ }^{\circ} \mathrm{C}$, após a qual os carboidratos redutores formados foram quantificados (Lever, 1972). Os substratos insolúveis foram retirados através de centrifugação previamente a quantificação dos carboidratos redutores. 


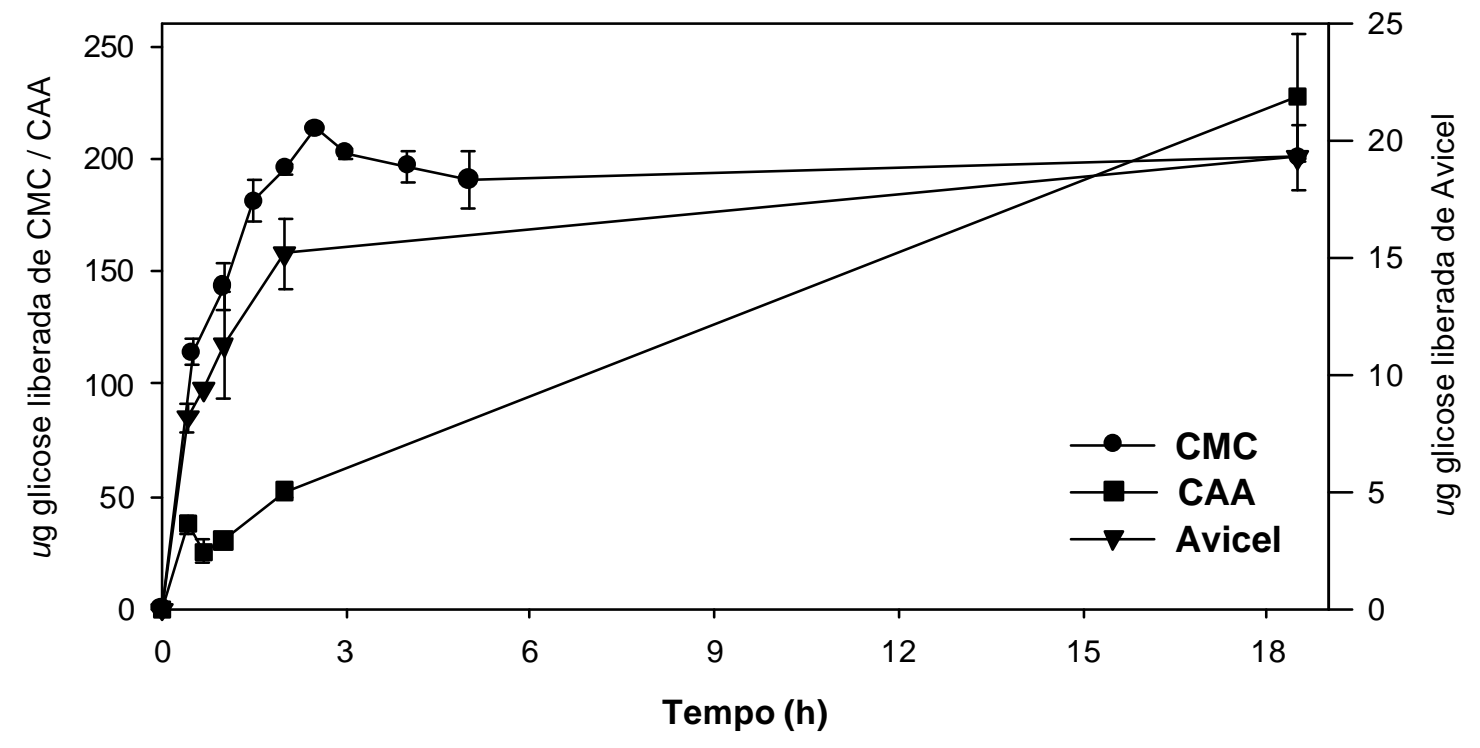

Figura 26- Hidrólise dos substratos carboximetil celulose (CMC •), celulose microcristalina (Avicel ) e celulose amolecida com ácido (CAA ) pela celulase Xf - 818. Os substratos foram preparados a $1 \%(\mathrm{~m} / \mathrm{v})$ em tampão acetato de sódio - ácido acético $50 \mathrm{mM}$ pH 5,2 e foram empregadas $111 \mathrm{U}$ da enzima Xf - 818. A reação foi mantida pelo tempo indicado a $65^{\circ} \mathrm{C}$, e os carboidratos redutores formados foram quantificados (Lever, 1972). Pontos representam média de 2 repetições com desvio padrão da média. 


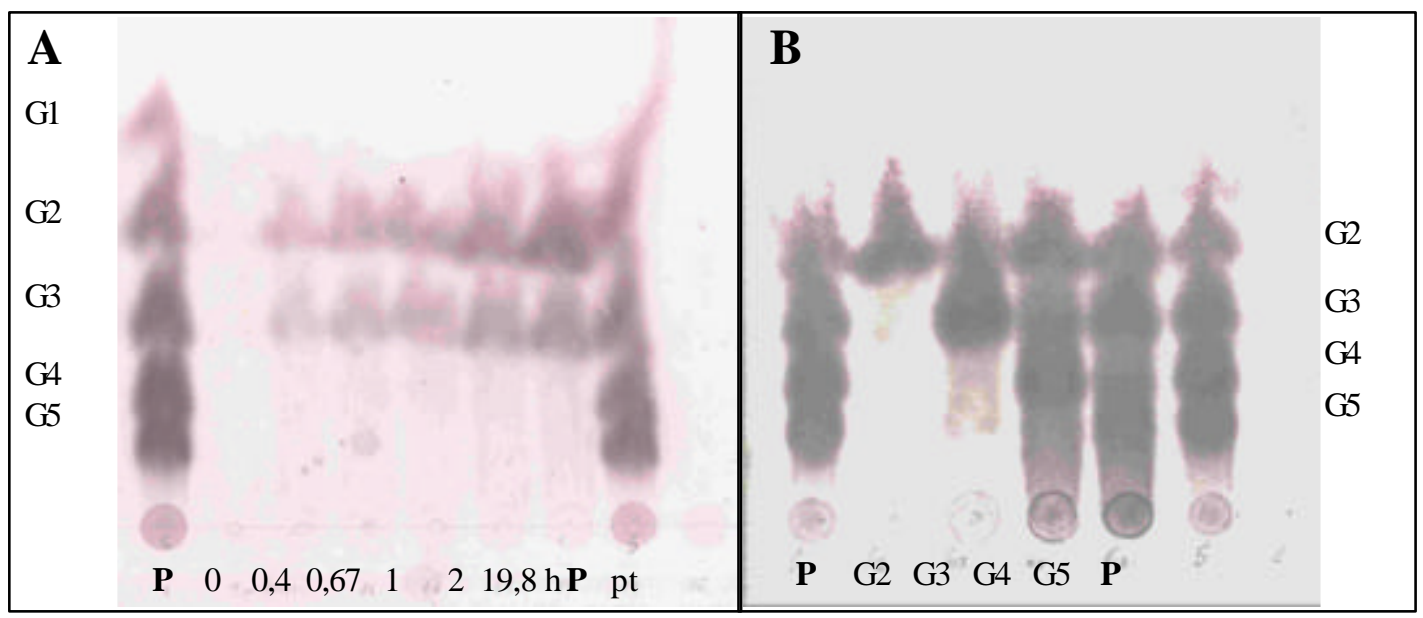

Figura 27 - Cromatografia de camada delgada de oligossacarídeos. A. Produtos da hidrólise da celulose amolecida com ácido pela Xf - 818 (111 U). Amostras do polímero foram incubados pelo tempo indicado a $65{ }^{\circ} \mathrm{C}$. B. Hidrólise pela endoglicanase Xf - 818 dos celooligossarídeos celobiose (G2), celotriose (G3), celotetraose (G4) e celopentaose (G5). Uma unidade da enzima foi incubada com $10 \mu \mathrm{L}$ de uma solução $10 \mathrm{mM}$ de cada açúcar durante $4 \mathrm{~h}$ a $40{ }^{\circ} \mathrm{C}$. A cromatografia foi efetuada com uma mistura de clorofórmio:ácido acético:água (6:7:1 v/v/v) e os açúcares foram revelados com "spray" de $N$-(1-naftil)etilenodiamina dihidrocloreto de $6,5 \mathrm{mM}$ aplicado sobre a placa. Este reagente é preparado em metanol (97 \%) e ácido sulfúrico (3\% v/v) e após aplicação a placa é aquecida a $100{ }^{\circ} \mathrm{C}$ durante 5 a 10 min em estufa. $\mathrm{P}=$ padrão com celooligossacarídeos $(\mathrm{G} 2$, G3, G4 e G5). 


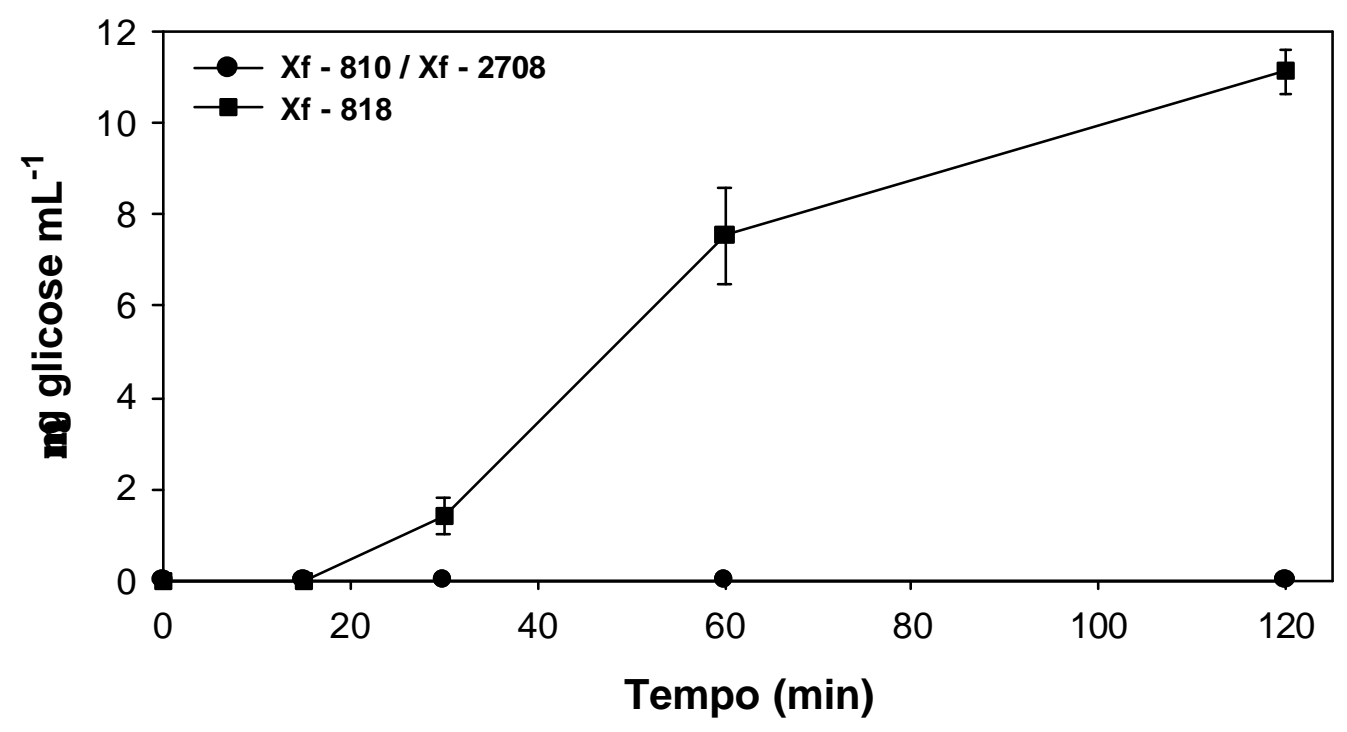

Figura 28 - Ensaio de capacidade de ligação à Avicel - celulose microcristalina. Quinze mg de celulose microcristalina (Avicel) foram lavadas com $1 \mathrm{~mL}$ de Tris- $\mathrm{HCl} 20 \mathrm{mM}$ pH 7,0; NaCl 200 mM e EDTA 1 mM. Esta suspensão foi centrifugada e ao pelete foi adicionado a amostra da proteínas Xf -810, Xf -818 ou Xf -2708 , a qual foi mantida uma hora sob agitação em temperatura ambiente. A suspensão foi centrifugada, o pelete de celulose foi lavado com $1 \mathrm{~mL}$ de tampão, misturado (vórtex) e novamente centrifugado. Esta etapa foi repetida 5 vezes. O pelete foi ressuspenso em tampão e uma alíquota de $100 \mu \mathrm{L}$ foi incubada com $200 \mu \mathrm{L}$ de tampão acetato $50 \mathrm{mM} \mathrm{pH} \mathrm{5,2} \mathrm{e} 200 \mu \mathrm{L}$ de CMC $1 \%$ em tampão acetato 50 $\mathrm{mM} \mathrm{pH}$ 5,2. Após períodos de 0,15, 30, 60 e 120 min de incubação a $40{ }^{\circ} \mathrm{C}$, a suspensão foi centrifugada e a quantidade de carboidratos redutores avaliada (Lever, 1972). Pontos representam média de 4 repetições com desvio padrão. 
Tabela 11. Degradação da carboximetil celulose pelas celulases Xf 810, Xf 818 e Xf 2708 de X. fastidiosa 9a5c produzidas em E. coli incubadas só ou em conjunto.

\begin{tabular}{lc}
\hline Enzima $^{1}$ & $\mu$ glicose liberada $^{2}$ \\
\hline Xf 810 & $0,9 \pm 0,3$ \\
Xf 818 & $5,5 \pm 1,9$ \\
Xf 2708 & $2,1 \pm 0,5$ \\
Xf $810+$ Xf 818 & $2,7 \pm 1,0$ \\
Xf $810+$ Xf 2708 & $0,5 \pm 0,5$ \\
Xf $818+$ Xf 2708 & $2,7 \pm 1,1$ \\
Xf $810+$ Xf $818+$ Xf 2708 & $0,4 \pm 0,5$ \\
\hline Foi utilizado 1 U de cada enzima, adicionada a $1100 \mu \mathrm{L}$ de CMC $1 \%$ em tampão \\
acetato 50 mM pH 5,2 e o volume foi completado a $2000 \mu \mathrm{L}$ com tampão fosfato 20 \\
mM pH 7,2. Esta mistura foi incubada 2 h a $40{ }^{\circ} \mathrm{C}$ e os carboidratos redutores foram \\
quantificados (Lever, 1972);
\end{tabular}


Tabela 12. Degradação de polímeros pelas celu lases Xf - 810, Xf - 818 e Xf - 2708 de X. fastidiosa 9 a5c produzidas em E. coli*.

\begin{tabular}{llccc}
\hline Polímero & Tipo de ligação & \multicolumn{3}{c}{ Celulases $^{1}$} \\
\cline { 3 - 5 } & & $\mathrm{Xf}-810$ & $\mathrm{Xf}-818$ & $\mathrm{Xf}-2708$ \\
\hline CMC & $\beta$-1,4 linear & $4,72 \pm 2,2$ & $31,02 \pm 1,6$ & $0,7 \pm 0,5$ \\
Avicel & $\beta-1,4$ linear & $2,7 \pm 0,5$ & $0,6 \pm 0,2$ & $0,6 \pm 0,1$ \\
Celulose tratamento & $\beta-1,4$ linear & $1,9 \pm 0,1$ & $0,6 \pm 0,2$ & nd $^{2}$ \\
ácido & & & & \\
$\alpha-$ celulose & $\beta-1,4$ linear & nd & nd & nd \\
"Birch wood" Xilana & $\beta-1,4$ & $6,72 \pm 0,8$ & $6,6 \pm 0,3$ & $4,7 \pm 4,1$ \\
"Oat spels" Xilana & $\beta-1,4$ & nd & $9,8 \pm 0,1$ & $2 \pm 1,1$ \\
Goma xantana & $\beta-1,4$ & nd & nd & nd \\
Laminarina & $\beta-1,3$ linear & nd & nd & nd
\end{tabular}

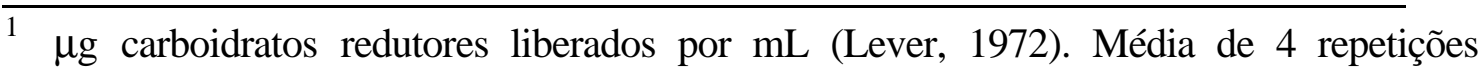
seguido de desvio padrão da média;

2 nd = não detectado.

* Enzima e substratos incubados durante $2 \mathrm{~h}$ a $45^{\circ} \mathrm{C} ; 1 \mathrm{~h} \mathrm{a} 65^{\circ} \mathrm{C}$ para Avicel e 40 min a $65^{\circ} \mathrm{C}$ para celulose amolecida com ácido. 


\section{DISCUSSÃO}

\subsection{Clonagem dos genes nos vetores de expressão}

Obtivemos sucesso na clonagem dos genes Xf $-810, \mathrm{Xf}-818$ e Xf -2708 nos vetores de expressão pET20b e/ou pET28b. Entretanto, não fomos capazes de efetuar a clonagem da celobiohidrolase Xf - 1267, embora a mesma tenha sido amplificada através da PCR.

A opção pelo emprego dos plasmídios de expresão pET20b e pET28b vem da possibilidade de utilizar as mesmas enzimas de restrição para clonar um dado gene em ambos os plasmídios. Esta possibilidade é interessante pois ambos os plasmídios apresentam características diferentes (Figura 6) e, dependendo de como foi efetuada a clonagem, pode-se obter a proteína heteróloga nativa ou com a cauda hexahistidina (recombinante), como fusão à extremidade $\mathrm{N}$ ou $\mathrm{C}$-terminal. Por exemplo, no plasmídio pNAW3 o gene $\mathrm{Xf}-818$ foi clonado com a estrutura original (proteína nativa). O mesmo gene $\mathrm{Xf}-818$, quando subclonado a partir de pNAW3 em pET28b, originando pNAW4, produz uma proteína recombinante com a cauda hexahistidina $\left(\mathrm{His}_{6}\right) \mathrm{N}$-terminal clivável com trombina. A cauda de hexahistidinas $\left(\mathrm{His}_{6}\right)$ é empregada na purificação de proteínas através de cromatografia de afinidade em metal imobilizado (Nilsson et al., 1997). A localização da cauda His 6 , na extremidade $\mathrm{N}$ - ou C- terminal pode influenciar a taxa de purificação da proteína recombinante através de IMAC. 


\subsection{Expressão das proteínas heterólogas}

Os sistemas de expressão que utilizam E. coli apresentam diversas vantagens. Como esta bactéria é comumentemente utilizada nos protocolos de manipulação de DNA, a maioria dos laboratórios está capacitada a manipulá-la e apresentam as condições mínimas para esse fim. As técnicas necessárias para a produção de quantidades apreciáveis da proteína são relativamente simples. O tempo necessário para gerar e superexpressar uma linhagem é teoricamente pequeno. É facil manipular E. coli, a bactéria cresce rápido e em meio

relativamente barato. É possível utilizar todo conhecimento da genética e fisiologia que sabemos desta bactéria, assim como toda a vasta literatura disponível sobre este organismo e suas aplicações. Entretanto, podem haver empecilhos também: proteínas expressas em grandes quantidades freqüentemente precipitam em agregados insolúveis denominados de corpos de inclusão. Também é difícil secretar uma grande quantidade de proteína $(E$. coli usualmente não secreta proteínas no meio), embora uma quantidade apreciável possa ser encontrada no periplasma (Ausubel et al., 1998). A formação de corpos de inclusão pode ser benéfica em alguns casos, principalmente quando a proteína é suscetível à degradação proteolítica. É necessário entretanto, que a proteína apresente resistência a agentes desnaturantes e que a mesma tenha capacidade de sofrer o processo de renaturação.

A polimerase do RNA T7 parece ser capaz de produzir eficientemente transcritos completos de qualquer DNA, sob o controle do promotor T7 (Studier \& Moffatt, 1986). Dois fatores contribuem para a eficiência deste sistema. O promotor T7 não é encontrado em E. coli, tornando o processo de indução muito específico. A polimerase do RNA de E. coli não utilizada o promotor T7. Mesmo assim, um pouco da proteína-alvo pode ser observada em células não induzidas, devido ao nível basal de expressão da polimerase do RNA T7 (o gene 1 do fago T7 codifica a polimerase do RNA T7).

A linhagem lisogênica BL21( $\lambda$ DE3) contém uma cópia cromosomal única do gene para a polimerase do RNA T7, sob o controle do promotor induzível lacUV5 (Studier \& Moffatt, 1986). A adição de IPTG (lactose ou outro análogo) induz o promotor lacUV5 a 
produzir a polimerase do RNA T7, a qual inicia a expressão em altos níveis do gene alvo no plasmídio sob o controle do promotor T7 (Figura 5). A indução é feita usualmente com 0,4 a $1 \mathrm{mM}$ IPTG quando a cultura atinge $\mathrm{A}_{600}$ de 1 ( $5 \times 10^{8}$ a $10^{9}$ células viáveis por $\left.\mathrm{mL}\right)$. Pode-se adicionar rifampicina após indução, o que inibe a polimerase do RNA de $E$. coli, mas não a polimerase do RNA T7 (Studier \& Moffatt, 1986). Os resultados de Studier \& Moffatt (1986) indicam claramente que a polimerase do RNA T7 é capaz de canalizar os recursos da célula na produção da proteína alvo sob o controle do promotor $\mathrm{T} 7$ no plasmídio. Provavelmente, este fato advém da alta processividade da enzima e pelo esgotamento dos precursores de RNA. A grande quantidade de RNAm produzida pela polimerase do RNA T7 pode ser suficiente para saturar o aparato sintetizante de proteína em E. coli. Em condições favoráveis, essencialmente todos os recursos da célula podem ser voltados à produção de uma única proteína, a qual pode acumular rapidamente e atingir $50 \%$ ou mais da proteína total da célula. Quando o plasmídio contém o terminador natural para a polimerase do RNA T7 do DNA T7 (T $\phi)$, a maior parte dos trancritos termina neste ponto.

O indutor IPTG, amplamente utilizado para a indução da expressão, pode ser substituído por lactose, visto que o IPTG é um análogo da lactose. Além de ser um composto mais barato e não tóxico como o IPTG, a lactose pode auxiliar na purificação da proteína recombinante, por aumentar, por exemplo a porção solúvel da proteína heteróloga, sem diminuir o nível de expressão (Monteiro et al., 1999) e não causar uma explosão metabólica na célula (Kilikian et al., 2000). Entretanto, os níveis de expressão da proteína leteróloga atingidos com IPTG são mais rápidos e maiores, de acordo com Kilikian et al. (2000).

A polimerase do RNA T7 por si só não é toxica às células de E. coli: derivativos de DE3 como E. coli BL21(DE3) crescem da mesma maneira na presença ou na ausência de IPTG. Entretanto, quando a célula contém um plasmídio com cópia do promotor T7, a indução da polimerase do RNA T7 usualmente mata a célula. A abilidade da célula em tolerar tanto o gene 1 e o promotor T7, depende do nível de polimerase do RNA T7 ativa na célula e do efeito da transcrição do promotor T7 na célula (Studier \& Moffatt, 1986). Plasmídios contendo genes alvo inócuos sob o controle do promotor T7 são estáveis. 
Problemas de instabilidade plasmidial podem ser superados assegurando-se que o estoque contenha o plasmídio induzível, utilizando colônias que tenham crescido em placas contendo antibiótico (Studier \& Moffatt, 1986).

A lisozima T7 é uma enzima bifuncional que cliva uma ligação ( $N$-acetilmuramilL-alanina amidase) na parede celular de E. coli e inibe seletivamente a polimerase do RNA T7 por ligar-se a ela. Esta proteína é codificada pelo gene 3.5 do fago T7. Este gene, clonado em plasmídio compatível com os plasmídios derivados de pBR322, como os plasmídios pET, denominado de pLysS, produz baixos níveis de lisozima T7 em células de BL21(DE3) não induzidas. Estes baixos níveis têm pouco efeito no crescimento das células, devido à compartimentalização no interior da célula, sem entrar em contato com a camada peptideoglicana, não causando a lise da cultura durante o crescimento, nem interferindo com a transformação por plasmídios compatíveis. Inibe, entretanto, a transcrição basal pela polimerase do RNA T7, sendo indicada na expressão de proteínas tóxicas a E. coli (Figura 5). Este plasmídio é mantido pela seleção com cloranfenicol. Adicionalmente, a presença desta enzima facilita a preparação de extratos celulares para a purificação das proteínas-alvo (Studier, 1991).

Em nosso trabalho, os plasmídios pET empregados, pET20b e pET28b, foram ferramentas eficientes para a expressão heteróloga das proteína de X. fastidiosa em E. coli. As proteínas estudadas apresentaram-se solúveis, sendo possível extraí-las das células de $E$. coli através de ciclos de congelamento e descongelamento. Tomando-se a proteína Xf -818 como exemplo, podemos observar que foram atingidos níveis de expressão satisfatórios desta proteína heteróloga (Figuras 12 e 13).

\subsection{Purificação das proteínas heterólogas}

A estratégia de clonagem dos genes de $X$. fastidiosa nos vetores $\mathrm{pET}$ foi feita com o objetivo de produzirmos quantidades suficientes de proteínas para realizar os ensaios enzimáticos com as proteínas heterólogas e purificá-las. Desta forma, a introdução de uma 
cauda de hexahistidinas na extremidade da proteína, a cauda $\mathrm{His}_{6}$ tag, foi feita com o intuito de permitir sua purificação através de IMAC.

Seguindo os protocolos recomendados (Ausubel et al., 1998), não foi possível efetuar a purificação das proteínas através de uma passo único que empregou a cromatografia de afinidade em metal imobilizado. Visando superar esta dificuldade não esperada, optamos por efetuar precipitação fracionada das proteínas presentes no lisado das células de E. coli, seguido de outras técnicas cromatográficas. Intercalando a cromatografia de troca aniônica, IMAC e exclusão molecular, estabelecemos um protocolo capaz de purificar a proteína Xf 818 recombinante contendo a cauda $\mathrm{His}_{6}($ Figura 20). O mesmo protocolo pode ser eficiente para a purificação de Xf - 2708, pois a proteína comporta-se de maneira semelhante que Xf 818 nos ensaios cromatográficos e também pode ser estendido à proteína Xf - 810 .

Monteiro et al. (1999), empregando o mesmo sistema de expresão, também encontraram dificuldades na eliminação de proteínas contaminantes de E. coli na cromatografia de afinidade em metal. Para a purificação da proteína NifA (NifA com a cauda hexahistidina N-terminal), foram necessárias alterações de composição do tampão, como força iônica, sais, presença ou ausência de DTT ou glicerol e diferentes concentrações de imidazol para eliminar proteínas contaminantes não especificamente ligadas a coluna $\mathrm{Hi}$-Trap-Chelating- $\mathrm{Ni}^{+2}$, a mesma empregada neste trabalho. Resinas iônicas (SP-Sepharose e Q-Sepharose) e sepharose-heparina não auxiliaram na purificação (Monteiro et al., 1999). Adicionalmente, a expressão desta proteína somente foi eficiente sob indução com lactose. Sob indução de IPTG $(0,5 \mathrm{mmol} / \mathrm{L})$ houve alta indução da proteína, mas somente $5 \%$ permaneceu solúvel. Quando em indução com lactose a $0,5 \%(\mathrm{~m} / \mathrm{v})$, os níveis de expressão foram similares aos obtidos com IPTG, entretanto, até $40 \%$ da proteína recombinante ficou solúvel (Monteiro et al., 1999).

Para concentrar proteínas em grande quantidade, empregamos a saturação a $80 \%$ de sulfato de amônio. Neste caso estavamos interessados em rendimento, onde buscamos toda a proteína de interesse na forma mais concentrada possível. Por outro lado, se o objetivo foi a eliminação de proteínas outras que não a de interesse, optamos pela precipitação fracionada, onde gradualmente precipitamos proteínas em concentrações 
crescentes de sulfato de amônio. Especificamente buscamos purificação, e podemos deixar o rendimento em segundo plano.

A precipitação fracionada com sulfato de amônio ao mesmo tempo que concentra as proteínas, separa-as grosseiramente pela sua massa (Scopes, 1982), como pode ser observado nas Figuras 14 e 15. Empregando os precipitados a 60 e $80 \%$ de sulfato de amônio, que apresentavam substancialmente uma menor diversidade de proteínas, efetuamos cromatografia de troca iônica e filtração em gel, visando com o emprego conjunto destas técnicas e IMAC obter a purificação das celulases Xf - 818 e 2708.

O princípio da troca iônica toma por base a interação eletrostática de moléculas carregadas com cargas positivas ou negativas e respectivas resinas com cargas negativas ou positivas. Na exclusão molecular, as moléculas são separadas de acordo com o tamanho, numa técnica também descrita como peneiramento molecular. A resina consiste de uma rede molecular tridimensional aberta, organizada na forma de esferas para facilidade de empacotamento no interior de uma coluna. Os poros dentro das esferas são de determinado tamanho, ficando inacessíveis a moléculas grandes, mas as moléculas menores podem penetrar todos os poros (Scopes, 1982). Assim, conforme o tampão percorre os poros da matriz, as proteínas são separadas de acordo com o tamanho, com as moléculas maiores sendo eluídas da resina antes das menores.

A interação das cadeias laterais de certos aminoácidos, particulamente a histidina, na superfície protéica com íons metálicos de transição imobilizados, numa técnica conhecida como cromatografia de afinidade em íon metálico imobilizado "immobilized metal ion affinity chromathography" - IMAC, é uma técnica eficiente e amplamente empregada. Esta técnica é utilizada na purificação de proteínas recombinantes, onde fusionou-se uma cauda de histidinas. Esta fusão, localizada na extremidade amina ou carboxila-terminal, freqüentemente contém seis histidinas contíguas (hexahistidina). As proteínas de uma amostra são aplicadas em coluna para IMAC em tampão contendo alta molaridade de sais $(0,4$ a $0,5 \mathrm{M} \mathrm{NaCl})$. Isto evita a interação eletrostática das proteínas com a matriz, impedindo o efeito de troca iônica. Após a eluição das proteínas sem afinidade pela resina, as proteínas que ficaram adsorvidas 
são seletivamente eluídas com o aumento na concentração de um competidor (imizadole) ou pela redução do pH do tampão. Nesta etapa, as proteínas contendo cauda de hexahistidinas são eluídas.

Como a estratégia aqui empregada não foi eficiente na purificação via passo único, e diversos vetores foram preparados com este propósito, podem ser testados outros sistemas para a purificação, os quais podem ser mais efetivos que o empregado neste trabalho. Existem no mercado outras resinas designadas para purificação de proteínas com cauda His 6 via IMAC, como a resina ácido nitriloacético-níquel (Qiagen, Valencia, CA - USA) e a resina Talon (Clontech, Palo Alto, CA - USA). Embora o princípio seja o mesmo, cada sistema tem peculiaridades próprias, que dependendo da situação empregada podem ser ou não, mais efetivos na purificação das moléculas de interesse. O emprego destas resinas pode ser uma alternativa futura quando da tentativa de purificação das celulases recombinantes de $X$. fastidiosa. Outra possibilidade é a utilização destes plasmídios para a expressão em outras linhagem de E. coli, portadora do gene da polimerase do RNA T7( $\lambda$ DE3), como JM109, BLR, AD494, HMS174 ou B834. A diferença no "background" genético e na expressão das proteína de E. coli pode interferir na abundância e nível das proteínas indesejáveis.

\subsection{Celulases de $X$. fastidiosa}

Neste item serão discutidas as características das celulases com base na sua sequiência primária (item 5.5.1) e posteriormente nas propriedade enzimáticas destas proteínas (item 5.5.2). Esta separação visa facilitar a compreensão de pontos distintos, que merecem considerações próprias, mas entretanto, derivam tão somente da mesma estrutura, que é a estrutura proteica oriunda dos genes. 


\subsubsection{Características das proteínas}

Atualmente, a forma mais rápida de predizer a possível função de um segmento de DNA é efetuar a comparação de sua sequiência com as depositadas em bancos de dados públicos, como o do NCBI (http://www.ncbi.nlm.nih.gov) ou o Expasy (http://www.expasy.ch). Embora a função putativa de um produto gênico possa ser identificada pela comparação da sequiência, é necessária sua confirmação através da análise do produto proteico expresso. Também, a caracterização do produto expresso é essencial para fornecer informações adicionais tais como a especificidade ao substrato, enantioseletividade e estabilidade (Hough \& Danson, 1994).

Assim, a análise da sequiência pode fornecer dados importantes que orientam o estudo da determinação da função biológica da proteína.

Muitas enzimas contêm múltiplos domínios, mas a classificação é feita com base na similaridade da sequiência de aminoácidos do domínio catalítico ou putativamente catalíticos (Gilkes et al., 1991; Henrissat, 1991). Membros de uma mesma família são caracterizados por regiões com alto grau $(\ell 64 \%)$ de similaridade de sequiência, com várias regiões onde a similaridade é baixa ou ausente (Henrissat et al., 1989).

A classificação baseada na similaridade de seqüência reconhece regiões do domínio catalítico que formam a estrutura geral compartilhada por todos os membros da família, nos quais a topologia do sítio ativo e portanto a estereoseletividade é conservada. Regiões dissimilares incluem elementos que contribuem para outros aspectos do comportamento catalítico, tais como o modo de clivagem (endo versus exo) e outras variações na especificidade ao substrato observada dentro das famílias (Gebler et al., 1992). As glicanases e glicosidases catalisam hidrólise estereoseletiva, onde a configuração em relação ao centro anomérico é invertida (reação de reposição única) ou é retida (reação de dupla reposição) na hidrólise da ligação glicosídica. As enzimas analisadas da família 5 catalisam a hidrólise com a retenção da configuração anomérica (Gebler et al., 1992) e provavelmente através de um mecanismo de dupla reposição (double-displacement) envolvendo um 
intermediário covalente enzima-glicosil (Sinnott, 1990). Gebler et al. (1992) sugerem que os membros de uma família compartilhem a estrutra topológica do sítio ativo e mecanismo catalítico similares. Assim, é plausível supor que todas as $\beta$-1,4-glicanases de uma dada família compartilhem uma estereoespecificidade comum (Gebler et al., 1992; Meinke et al., 1993).

As endo- e exo-glicanases clivam pontes $\beta$-1,4-glicosídicas e sua especificidade parece ser determinada pela topologia de seu sítio ativo. As endoglicanases possuem o sulco do sítio ativo aberto, enquanto o sítio ativo das exoglicanases é localizado no túnel formado pela estrutura da proteína (Linder \& Teeri, 1997). As variações catalíticas encontradas nas celulases relacionam-se ao modo de ataque ao polímero, podendo apresentar clivagem endo ou exoglicolítica em graus variados, quanto aos substratos hidrolisados e aos produtos formados (Gilkes et al., 1991). Outra variação presente é quanto à capacidade de ligação ao substrato, a qual pode ser otimizada pela presença de um domínio ligador de celulose. Portanto, a caracterização das propriedades catalíticas de uma enzima, neste caso, das enzimas com atividade celulásica, pode esclarecer ou fornecer subsídios para se entender a função destas enzimas no contexto do organismo portador dos genes.

A família 5 (previamente família A) das hidrolases glicosídicas englobam enzimas com atividade de endoglicanase, celobiohidrolase, endoxilanase, manosidase, $\beta-1,3$ glicanases. Portanto, a caracterização dos genes acima descritos requer a análise enzimática da função das enzimas por eles codificados para que sua atividade possa ser caracterizada e descrita. Nos ensaios apresentados (item 4.4) ficou evidente que os genes Xf - 810, Xf - 818 e Xf - 2708 podem ser considerados verdadeiramente como celulases ou melhor, como endoglicanases, pois clivam a celulose internamente na cadeia, o modo característico de ação das endoglicanases. Esta observação corrobora a análise obtida com a similaridade de seqüência destas proteínas (item 3.2), que evidencia a maior similaridade destas proteínas com as endoglicanases e as classificou como pertencentes à família 5.

As endoglicanases Xf - 810 e Xf - 818 apresentam similaridade com membros da subfamíla 1, enquanto em Xf - 2708 a melhor similaridade é observada com membros da 
subfamília 5, ambos dentro da família 5 (Henrissat, 1991; Henrissat \& Bairoch, 1993). A celobiohidrolase Xf - 1267 possui maior similaridade com a famíla 6. O nível de similaridade com o consenso do domínio catalítico da família 5 observado em Xf - 810 é substancialmente menor que o das outras celulases. Xf -810 apresenta similaridade entre os aminoácidos 10 a 196, enquanto em Xf - 818 esta similaridade é observada nos aminoácidos 31 a 348 e em Xf - 2708 entre os aminoácidos 34 e 326. Enquanto esta diferença não pode ser relacionada ao tamanho do gene, pois Xf - 2708 apresenta somente $1071 \mathrm{pb}$, sendo a menor das três endoglicanases (Tabela 5), a ausência de similaridade também reflete-se na ausência de aminoácidos conservados encontrados tipicamente da família 5 (Tabela 8; Wang et al., 1993), um tópico que será discutido abaixo.

Segundo Gilkes et al. (1991) é marcante que um dado organismo possua enzimas de diferentes famílias e em contraste, somente um tipo de DLC, como é o caso observado em $X$. fastidiosa 9a5c (Simpson et al., 2000), uma característica que pode ter sido adquirida pela aquisição horizontal de genes. As proteínas Xf - 818 e Xf - 1267 são de famílias diferentes, mas apresentam DLC do tipo II.

O radical ácido glutâmico (E), conservado entre todos os membros da família 5 das hidrolases glicosídicas, é essencial para a atividade catalítica de pelo menos algumas endoglicanases (Baird et al., 1990; Py et al., 1991; Wang et al., 1993). Wang et al. (1993) confirmaram a conservação de sete aminoácidos nas enzimas pertencentes à família 5, anteriormente descritos como conservados em alinhamentos parciais (Baird et al., 1990; Belaich et al., 1992; Guiseppi et al., 1988). Tomando por base o alinhamento efetuado por Wang et al., (1993) e as posições dos aminoácidos de CelC de Clostridium thermocelum, comparamos as posições destes aminoácidos conservados com aquela dos aminoácidos das celulases de X. fastidiosa (Simpson et al., 2000), da endoglicanase de X. c. campestris (Gough et al., 1990) e de Cel5 de E. chrysanthemi (Chapon et al., 2001; Guiseppi et al., 1988). Como $\mathrm{E}^{280}$ é identificado como o nucleófilo sítio ativo, é altamente provável que $\mathrm{E}^{140}$ funcione como o catalista ácido/base (Meinke et al., 1993, Wang et al., 1993). O ácido glutâmico, considerado nucleófilo $\left(\mathrm{E}^{280} \mathrm{em} \mathrm{CelC}\right.$ de $C$. thermocelum) está presente em todas 
as enzimas, entretanto o catalista ácido base, ácido glutâmico $\left(\mathrm{E}^{140}\right)$ em CelC, está ausente na celulase Xf -810 , estando presente uma histidina $\left(\mathrm{H}^{163}\right)$ em seu lugar. Assim, Xf -810 apresenta ao invés do ácido glutâmico $(\mathrm{E})$ uma histidina $(\mathrm{H})$ na posição conservada relativa ao catalista ácido base. A implicação desta alteração na atividade catalítica da enzima não é conhecida até o momento. Stryer (1996) no entanto, ressalta que a histidina, um aminoácido com cadeia lateral muito polar e altamento hidrófilo, pode não ter carga ou tê-la positiva, dependendo do seu ambiente local. A histidina é freqüentemente encontrada nos centros ativos de enzimas, onde seu anel imidazólico pode prontamente se alternar entre esses estados para catalisar a feitura e quebra de ligações. Assim, embora esta diferença de aminoácido conservado $(\mathrm{E} 163 \mathrm{H})$ pareça ser viável do ponto de vista catalítico, vide sua atividade, é marcante devido à diferença com as enzimas da família 5.

A sequiência de aminoácidos $\mathrm{N}^{168} \mathrm{E}^{169} \mathrm{P}^{171} \mathrm{H}^{172}$ de CenD (C. fimi) é conservada na sub-família 5-1, correspondendo a $\mathrm{N}^{139} \mathrm{E}^{140}$ de CelC (C. thermocelum) (Meinke et al., 1993; Wang et al., 1993), que são aminoácidos conservados na família 5, incluindo o nucleófilo sítio ativo (E). Esta seqüência em Xf - 810 apresenta somente a asparagina (N) conservada na seqüência $\mathrm{N}^{162} \mathrm{H}^{163} \mathrm{R}^{164} \mathrm{P}^{165} \mathrm{~F}^{166}$. Assim, a histidina $(\mathrm{H})$ repõe o ácido glutâmico (E) na posição de catalista ácido base, e a arginina (R) ou qualquer outro aminoácido, não é encontrado nesta posição antes da prolina $(\mathrm{P})$. Mutantes na posição $\mathrm{E}^{140} \mathrm{de}$ CelC (C. thermocelum) apresentaram menos de $1 \%$ da atividade enzimática (Navas \& Béguin, 1992) e a mesma mutação nas celulases de B. subtilis, B. polymyxa (Baird et al., 1990), e Cel5 de E. chrysanthemi (Py et al., 1991), resultam em enzimas com menos de $5 \%$ da atividade enzimática. Gough et al. (1990) consideraram $\mathrm{H}^{136}$ e $\mathrm{E}^{182}$ como aminoácidos potencialmente catalíticos na endoglicanase EngXCA de X. campestris pv. campestris, tomando por base o trabalho de Henrissat et al. (1989). Entretanto, atualmente esta consideração foi superada pelas observações de Wang et al. (1993), de onde observamos que os dois ácido glutâmicos exercem a função catalítica e a histidina tem função estrutural (Tabela 8). Veja também o Apêndice 3. 
A enzima Cel5 de E.chrysanthemi, cinco aminoácidos estritamente conservados no sítios catalítico foram caracterizados. São estes os ácidos glutâmicos identificados como nucleófilo e catalista ácido base, $\mathrm{E}^{133}$ e $\mathrm{E}^{220}$, respectivamente; as histidinas $\mathrm{H}^{98}$ e $\mathrm{H}^{192}$ que são cruciais para a catálise e a arginia $\mathrm{R}^{57}$ (Tabela 8), que formam diversas pontes de hidrogênio, principalmente com os outros aminoácidos no centro catalítico. Além dos aminoácidos identificados como nucleófilo e catalista ácido base, os outros radicais conservados provalmente têm uma função na estabilidade da estrutura do domínio (como $\mathrm{H}^{98} \mathrm{e}$ $\mathrm{H}^{192}$ de Cel5A), na formação de sítios de ligação ao açúcar ou na orientação e ativação dos radicais ácido glutâmico (E) ativos (Chapon et al., 2001; Meinke et al., 1993; Py et al., 1991;). Desta forma, embora o nucleófilo esteja conservado em Xf - 810, três dos sete aminoácidos conservados não estão presentes nesta enzimas, o que juntamente com sua baixa similaridade do domínio catalítico da família 5 (somente 186 aminoácidos são similares) pode caracterizar esta enzima como a menos semelhante às enzimas desta família. O mesmo padrão é observado nas seqüências similares em $X$. fastidiosa PD, Dixon e Ann-1, sendo que na linhagem Dixon a diferença é mais expressiva (Apêndice 3). A posição de alguns aminoácidos conservados em Xf-2708 é um pouco deslocada na X. fastidiosa PD e Dixon, em relação ao clone 9a5c. Mesmo assim, com esta alteração no padrão geral da seqüência das hidrolases glicosídicas, esta enzima continua cataliticamente ativa sobre ligações $\beta$-1,4-piranosídicas. Entretanto, o processo de manutenção de bases não conservadas, pode resultar numa enzima com menor atividade catalítica ao longo do processo evolutivo.

A proteína Xf - 818 tem um domínio ligador de celulose do tipo II. Atualmente, os DLC são classificados como domínios ligadores de carboidratos ou CBM ("carbohydrate binding module") devido a sua ocorrência em outras enzimas que não somente as celulases. CBMs são encontrados em todos tipos de celulases e algumas hemicelulases (xilanase e mananases) e até em quitinases. Entretanto, os DLCs geralmente não apresentam afinidadade por xilanas ou mananas, embora domínios ligadores de xilana já foram descritos (Linder \& Teeri, 1997). O DLC da Xf - 818 com 83 aminoácidos, é um pouco menor do que os tipicamente obsevados no tipo II (Linder \& Teeri, 1997). A presença de 4 aminoácidos 
triptofano (W) em posições conservadas condiz com a possível função destes domínios e a presença de aminoácidos aromáticos em estruturas que ancoram à carboidratos. Entretanto, as cisteínas que flanqueiam os aminoácidos W não são encontradas nas posições conservadas, estando mais distais destes radicais triptofanos. As celulases CelA de $C$. m. sepedonicus e $C$. m. michiganensis pertencem à família 5 e possuem a mesma estrutura modular apresentada por Xf - 818, entretanto seu DLC do tipo II não contém as cisteínas flanqueadoras típicas (Jahr et al., 2000; Laine et al., 2000). Ademais, o DLC da CelA de C. m. michiganensis parece estar relacionado ao fenótipo patogênico (Jahr et al., 2000). A posição deste domínio DLC é variável, enquanto em CenA ( $C$. fimi) é N-terminal e o de Cex ( $C$. fimi) é C-terminal, uma endoglicanase e uma celobiohidrolase respectivamente, embora esta não seja uma característica que governe a atividade catalítica (endo versus exo-hidrolítica) da proteína (Gilkes et al., 1991).

Gilkes et al. (1991) e Poole et al. (1993) descrevem que o aminoácido triptofano é encontrado em posições específicas nos DLC. Poole et al. (1993) através de substituições específicas de triptofano (W) por fenilalanina (F) (ambos aminoácidos aromáticos) ou por alanina (A) (um aminoácido não polar), determinaram quais radicais triptofano eram imprescindíveis para a manutenção da capacidade de ligação à celulose. Na xilanase A (XynA) de Pseudomonas fluorescens subsp. cellulosa, onde foi efetuada esta caracterização, estes triptofanos apresentavam a seguinte distribuição $\mathrm{X}_{\mathrm{n}} \mathrm{W}^{12} \mathrm{X}_{21} \mathrm{~W}^{34} \mathrm{X}_{3} \mathrm{~W}^{38} \mathrm{X}_{10} \mathrm{~W}^{49} \mathrm{X}_{15} \mathrm{~W}^{66} \mathrm{X}_{\mathrm{n}}$ no DLC $\mathrm{N}$-terminal (onde $\mathrm{X}$ é qualquer aminoácido, o número subscrito denota o número de aminoácidos entre os aminoácidos especificados e o número sobrescrito a posição do aminoácido dentro do domínio). $\mathrm{O}$ aminoácido $\mathrm{W}^{66}$ (caracterizado na substituições $\mathrm{W}^{66} \rightarrow \mathrm{A}^{66} / \mathrm{F}^{66}$ ) não é importante para a ligação a celulose. A substituição em $\mathrm{W}^{49}$ por $\mathrm{F}\left(\mathrm{W}^{49} \rightarrow \mathrm{F}^{49}\right)$ mantém a capacidade de ligação, mas não aquela por $\mathrm{A}\left(\mathrm{W}^{49} \rightarrow \mathrm{A}^{49}\right)$. As alterações $\mathrm{W}^{38} \rightarrow \mathrm{F}^{38}, \mathrm{~W}^{34} \rightarrow \mathrm{F}^{34}$ ou $\mathrm{W}^{12} \rightarrow \mathrm{F}^{12}$ apresentam afinidade reduzida pela celulose microcristalina, enquanto $\mathrm{W}^{38} \rightarrow \mathrm{A}^{38}, \mathrm{~W}^{34} \rightarrow \mathrm{A}^{34}$ ou W $\mathrm{W}^{12} \rightarrow \mathrm{A}^{12}$ a capacidade de ligação é abolida. Din et al. (1994) também avaliaram o papel do triptofano na ligação à celulose de CenA, as alterações $\mathrm{W}^{14} \rightarrow \mathrm{A}^{14}$ ou $\mathrm{W}^{68} \rightarrow \mathrm{A}^{68}$, reduziram em 50 e 30 
vezes, respectivamente, a capacidadade de ligação da enzima CenA ( . fimi) na celulose. Estes trabalhos ressaltam a importância dos aminoácidos aromáticos na interação da estrutura proteica com açúcares. Os DLCs caracterizados apresentam estrutura tridimensional baseada em topologias de folha $\beta$, onde os radicais aromáticos estão expostos na superfície do domínio, juntamente com aminoácidos potencialmente envolvidos na formação de pontes de hidrogênio. Os aminoácidos aromáticos estão envolvidos na interação proteica com diversos carboidratos.

Em Xf - 818, a posição dos triptofanos no DLC apresenta a seguinte distribuição (numeração a partir do início da similaridade com o DLC tipo II: aminoácido 512 da proteína $\mathrm{Xf}$-818): $\mathrm{XnW}^{11} \mathrm{X}_{19} \mathrm{~W}^{31} \mathrm{X}_{13} \mathrm{~W}^{45} \mathrm{X}_{3} \mathrm{~W}^{49} \mathrm{X}_{13} \mathrm{~W}^{63} \mathrm{Xn}$, a qual difere um pouco da estrutura observada em XynA (Poole et al., 1993). O significado biológico desta distribuição deve ser levado em consideração na estrutura tridimensional adotada pela proteína.

A eficiência de ligação de uma enzima é aumentada consideravelmente pela presença do DLC e esta característica muitas vezes correlaciona-se com uma melhor atividade frente a substratos insolúveis. Confirmando esse ponto de vista, a remoção do DLC tem pouco efeito na hidrólise de substratos solúveis, enquanto a ligação e atividade das celulases em celulose insolúvel é diminuída (Linder \& Teeri, 1997). Como podemos observar na Figura 27, a endoglicanase Xf - 818 apresenta capacidade de ligação à celulose microcristalina, enquanto esta capacidade não é observada em Xf - 810 ou Xf - 2708, o que correlaciona-se com a presença do DLC do tipo II (Figura 7). Um DLC do tipo II também é observado em Xf -1276, uma possível celobiohidrolase de X. fastidiosa.

A endoglicanase Xf -818 e a celobiohidrolase Xf -1267 , apresentam seqüências de aminoácidos muito características na porção intermediária de suas estruturas primárias. São regiões similares aos conectores descritos em muitas glicanases e outras proteínas (Gilkes et al., 1991), também conhecidos como "hinge" ou dobradiça (Knowles, 1987). Estas regiões são quase sempre localizadas adjacentes ao domínio N- ou C-terminal da proteína e especula-se que tenham a função de separar o domínio terminal da proteína do domínio principal (Knowles, 1987). As regiões conectoras são caracterizadas por efetuarem a 
ligação entre domínios de uma mesma proteína, apresentam comprimento e conteúdo variáveis, com predominância de prolina e hidroxiaminoácidos, que podem estar presentes como repetições de pequenas seqüências de aminoácidos (Gilkes et al., 1991). Assim, estes conectores são predominante ricos em prolina, serina e treonina. Entretanto, nos conectores encontrados na endoglicase Xf - 818 e na celobiohidrolase (Xf - 1267) de X. fastidiosa 9a5c, a composição é quase que exclusiva de serina e glicina (Simpson et al., 2000). Analisando a função de estruturas semelhantes em outras proteínas, Gilkes et al. (1991) consideram que estes conectores formam algo como dobras flexíveis e extendidas entre os domínios da proteína. Em relação a este ponto cabe ressaltar que nas proteínas Xf - 818 e Xf - 1267 são observados "conectores" ricos em glicina e serina, exatamente nas proteínas que apresentam dois domínios característicos: o domínio catalítico $\mathrm{N}$-terminal e o domínio ligador de celulose C-terminal (DLC). Assim, a possível função destes "conectores" concordaria com àquela suposta por Gilkes et al. (1991). Linder \& Teeri (1997) citam que muitos conectores são glicosilados, uma característica que evitaria a proteólise, visto estas regiões serem suscetíveis a clivagem enzimática. Outras enzimas apresentam conectores com alto conteúdo de serina (S), como a $\beta$-glicanase e a celulase $\mathrm{C}$ de Fibrobacter succinogenes, as enzimas endoglicanases A e B, xilanases A, B e C de P. fluorescens subsp. celulosa, celulase A de Microbispora bispora (Gilkes et al., 1991). Usualmente estas enzimas apresentam módulos ligadores de carboidratos (como o DLC) e sua função pode ser relacionada aos conectores que permitiriam uma conformação apropriada para a ligação ao substrato e também à catálise enzimática (Gilkes et al., 1991). Ademais, as regiões ricas em glicina e serina de Xf - 818 e Xf - 1267 são similares ao colágeno e podem representar possíveis sítios de interação proteína-proteína. Outras enzimas microbianas ativas sobre carboidratos apresentam domínios que apresentam similaridade com fibronectinas do tipo III (Gilkes et al., 1991).

As celulases Xf - $818\left(\mathrm{e}^{-137}\right)$ e em menor grau Xf $-810\left(1 \mathrm{e}_{-}^{-47}\right)$ são similares a EngXCA de X. campestris pv. campestris (P19487), uma endoglicanase de 493 aminoácidos e 53,9 $\mathrm{kDa}$ (3.2.1.4) com estrutura modular similar. Esta endoglicanase de $X$ c. pv. campestris exerce uma pequena função nos primeiros estágios da patogenicidade em nabo e 
rabanete (Gough et al., 1988; Gough et al., 1990). Levando também em consideração a proximidade evolutiva destas bactérias (Wells et al., 1987), poderíamos esperar atividades similares nas celulases de X. fastidiosa e X. c. pv. campestris. Avaliações viscosimétricas e da produção de açúcares redutores mostraram que uma redução em 50 \% na viscosidade do substrato CMC foi acompanhado pela quebra de menos de $2 \%$ das pontes glicosídicas da CMC, confirmando a ação endoglicolítica das celulases de X. c. pv. campestris (Gough et al., 1988). As celulases Xf -810 e Xf - 818 apresentaram capacidade de hidrolisar a CMC, assim como a celulase Xf - 2708 (Tabela 12), confirmando a suposta atividade tomada com base na similaridade de seqüência de aminoácidos do domínio catalítico.

Gough et al. (1988) e Gough et al. (1990) descrevem a localização de duas endoglicanases em $X$. campestris pv. campestris, sendo uma extracelular e outra periplasmática. Assim, a importância biológica da possível presença de uma celulase no espaço periplasmático de algumas bactérias fitopatogênicas Gram-negativas deve ser melhor investigado. No sistema catabólico pectinolítico, a ocorrência de enzimas extracelulares e periplasmáticas é bem documentada. A celulase Xf - 810 pode não apresentar peptídio sinal (Simpson et al. 2000; http://aeg.lbi.ic.unicamp.br/xf/) ou esta informação pode ter representado um dado não incluso na anotação do genoma, pois a análise da seqüência flanqueadora destes gene através do ORFinder gerou uma proteína maior e com possível peptídio sinal N-terminal clivável (19 aminoácidos). A similaridade com as possíveis enzimas em X. fastidiosa Dixon e Ann1 (Bhattacharyya et al., 2002), e que apresentam aminoácidos adjacentes na extremidade $\mathrm{N}$-terminal (19 aminoácidos) suportam a possibilidade da presença do peptídio sinal.

Um fato que deve ser levado em consideração na análise de genes e genomas completos, é a análise periódica em busca de novos homólogos de sequiência. Este trabalho pode trazer resultados interessantes, por exemplo, no plasmídio de X. fastidiosa (pXf51) recentemente foi descrita uma nova orf, Xfa0065, a qual apresenta similaridade com proteínas envolvidas na conjugação. Como novos genes são descritos e caracterizados em outros organismos, genes previamente sem função conhecida podem vir a apresentar similaridade de sequiência com estes genes, auxiliando no entendimento de sua função. Outro fator que deve 
contribuir para a descoberta de novas orfs, é o aperfeiçoamento dos programas de computador, como observado na análise de Bhattacharyya et al. (2002). Reanalisando o genoma de $X$. fastidiosa 9a5c, estes autores encontraram um maior número de orfs do que o previamente analisado por Simpson et al. (2000).

\subsubsection{Propriedades catalíticas}

As enzimas são mantidas ao longo do processo evolutivo e durante este processo, podem acumular alterações que otimizam ou não a sua atividade catalítica. A catálise enzimática é governada por diversos fatores intrínsecos e extrínsecos. Os intrínsecos, decorrentes da estrutura primária da enzima, influenciam a capacidade catalítica possível de uma enzima. Por sua vez, os fatores externos ou extrínsecos influenciam positiva ou negativamente as propriedades catalíticas. Assim, uma enzima está modelada a trabalhar de maneira ótima em determinadas condições. A caracterização destas condições ótimas para catálise pode fornecer informações a respeito de suas funções no ambiente em que são produzidas.

As celulases atuam através de um mecanismo conhecido como catálise ácida geral. Na catálise ácida, um próton é transferido do aminoácido (ácido glutâmico na família 5 das hidrolases glicosídicas), que não está ionizado e em posição ótima a 3 angstrons de distância do átomo de oxigênio glicosídico. O termo ácida geral indica que a fonte de próton é um grupamento doador e não $\mathrm{H}^{+}$livre (Stryer, 1996).

As proteínas Xf - 810, Xf - 818 e Xf - 2708 apresentam similaridades de sequiência com diversas endoglicanases. As endoglicanases ou enzimas com código EC 3.2.1.4 efetuam a hidrólise interna de ligações $\beta$. As celobiohidrolases recebem o código EC 3.2.1.91, onde a Xf - 1267 possivelmente se encaixa, pois efetuam hidrólise de ligações $\beta$ 1,4-D-glicosídicas na celulose e celotetraose, liberando celobiose das extremidades não redutoras das cadeias. As celobiohidrolases são conhecidas como exoglicanases exatamente por atacarem a extremidade da cadeia do substrato. 
Derivados de celulose, tais como a carboximetil celulose (CMC) ou hidroximetil celulose (HEC), são empregados para a determinação da atividade de endoglicanases pois estes derivativos não são hidrolisados por exoglicanases. O método mais sensível para avaliar a atividade de endoglicanase é a avaliação da alteração na viscosidade de soluções de CMC ou HEC incubadas com a enzima (Pettersson \& Eriksson, 2000). A atividade de exoglicanases (cellobiohidrolase) pode ser avaliada com a utilização de hetrobiosídeos como $p$-nitrofenol- $\beta$-D-celobiosídeo como substrato (Deshpande et al., 1984) ou pela liberação de celobiose a partir da celulose microcristalina (Wood \& Bath, 1988).

A elevada temperatura ótima para hidrólise da $\mathrm{CMC}$, registrada em $65{ }^{\circ} \mathrm{C}$ (Figura 24) pode caracterizar as celulases de X. fastidiosa como enzimas termófilas (Hough \& Danson, 1999), embora X. fastidiosa seja caracteristicamente uma bactéria mesófila, com temperatura ótima de crescimento a $28{ }^{\circ} \mathrm{C}$ (Davis et al., 1978; Feil \& Purcell, 2001; Weels et al., 1987). As proteases de X. fastidiosa PD apresentaram alta estabilidade térmica, embora a temperatura ótima para catálise tenha sido menor, com maior atividade entre 40 e $60{ }^{\circ} \mathrm{C}$ (Fry et al., 1994). Em geral, as enzimas de um organismo são adaptadas para funcionar de maneira ótima nas condições idênticas ou próximas às condições de crescimento, de maneira que a variação de extremos na qual a vida é encontrada define a gama de condições na qual a atividade enzimática pode ser detectada (Hough \& Danson, 1994). Feil \& Purcell (2001), mostraram que populações de $X$. fastidiosa $\mathrm{PD}$ aumentam in vitro a 18, 22, 28 e $32{ }^{\circ} \mathrm{C}$, enquanto a população in planta (videira) aumenta a $25{ }^{\circ} \mathrm{C}$, permanece constante a $17{ }^{\circ} \mathrm{C}$, decrescendo a $10{ }^{\circ} \mathrm{C}$ e mais ainda a $34{ }^{\circ} \mathrm{C}$. No caso de $X$. fastidiosa $\mathrm{CVC}$, não foram efetuadas observações semelhantes, mas essas obsevações podem ter importantes consequiências epidemiológicas (Feil \& Purcell, 2001).

As celulases Xf - 810 e Xf - 818 apresentaram maior atividade catalítica em pH 5,2 e a celulase Xf - 2708 em pH 5,6 no tampão acetato de sódio. O espectro de ação sobre polímeros glicosídicos ou xilosídicos com ligações $\beta$-1,4 apresenta diferenças entre Xf 810, Xf - 818 e Xf - 2708. As três celulases hidrolisam a CMC e comparativamente hidrolisam menos eficientemente a celulose microcristalina (Avicel), embora as celulases não 
degradem a $\alpha$-celulose. O mesmo padrão de ação é observado sobre a xilana "Birch wood", uma xilana ramificada em menor extensão do que a arabinoxilana, com mais do que $90 \%$ de xilose (Kim, 1995).

Segundo Kim (1995), a arabinoxilana “Oatspels" tem uma estrutura altamente ramificada, com $75 \%$ de xilose, $15 \%$ de ácido glicorônico e $10 \%$ de arabinose. A alta atividade de uma endoglicanase sobre xilana indica que a enzima tem uma especificidade flexível para a posição C-6 na unidade glicopiranosídica na celulose (Kim, 1995), o que parece ser operante em Xf - 818. Esta mesma celulase, apresenta um domínio ligador de celulose DLC que permite a ancoragem da enzima a substratos insolúveis. Como em algumas celulases o DLC é necessário para a hidrólise de polímeros insolúveis, como a celulose microcristalina, poderíamos esperar a hidrólise da Avicel pela Xf -818 , devido à presença do DLC. A hidrólise de Avicel e celulose amolecida com ácido foi observada eficientemente pela enzima Xf - 818 quando foram empregadas $111 \mathrm{U}$ da enzima no ensaio (Figura 26). Ademais, neste ensaio ficou envidente a formação de celobiose e celotriose durante a degradação da celulose. A quantidade de celobiose e celotriose foi aparentemente maior na hidrólise de celulose amolecida com ácido do que em Avicel (Figura 27), pois o teste empregado apresenta características quantitativas (Bounias, 1980). Esta enzima também é capaz de hidrolisar celooligossacarídeos solúveis, como celotetraose e celopentaose. Devemos lembrar que na família 5 das hidrolases glicosídicas, encontramos enzimas com mecanismo endo e exohidrolítico e mesmo uma enzima pode apresentar ambas as atividades (Kim, 1995). Não foi observada a degradação dos celooligossacarídeos pelas celulases Xf - 810 e Xf - 2708, assim como a geração de oligossacarídeos pela hidrólise de celulose. Entretanto, não podemos excluir a possibilidade destas enzimas formarem estes açúcares, pois a quantidade de enzima empregada foi pequena e não houve possibilidade de fazer os ensaios nos moldes em que Xf 818 mostrou-se ativa sobre celulose cristalina.

A caracterização de uma enzima com tipo endo- ou exo- glicolítico pode apresentar algumas dificuldades. Shen et al. (1995) detectaram uma baixa atividade de endoglicanase em ensaio em placa (CMC corada com vermelho congo) com as 
celobiohidrolases CbhA e CbhB de C. fimi. A atividade de celobiohidrolase foi caracterizada em ensaio viscosimétrico. Assim estas duas celobiohidrolases são predominantemente, mas não exclusivamente exohidrolíticas (Shen et al., 1995). As CbhA e CbhB de C. fimi não hidrolisam o substrato $p$-nitrofenol- $\beta$-D-celobiosídeo $(p \mathrm{NPC})$, o qual tem sido considerado como um diagnóstico para atividade "exo-celobiohidrolase" (Deshpande et al., 1984). As exoglicanases progressivamente removem resíduos não-substituídos da extremidade da CMC e param quando encontram um resíduo substituído carboximetilados, pelo bloqueio do progresso adicional da enzima ao longo da cadeia. Isto significa que a concentração efetiva do substrato na solução de CMC no início da reação é muito menor para uma exoglicanase do que para uma endoglicanase e rapidamente aproxima-se de zero (Shen et al., 1995). Muitas ligações glicosídicas a mais são clivadas por uma endoglicanase de clivagem interna ao acaso (Gilkes et al., 1984). Entretanto, a caracterização de uma celulase como apresentando comportamento endo- ou exo-hidrolítico pode ser observado através do resultando dos seguintes ensaios. A inclinação da curva obtida plotando-se a geração de carboidratos redutores e a concomitante viscosidade de uma solução de CMC e a hidrólise de celulose microcristalina com consequente produção de celobiose como produto final. O ensaio em meio de cultura contendo CMC e posterior coloração com vermelho congo também é um bom indicador da atividade endoglicolítica, mas não deve ser considerado um ensaio definitivo (Kim, 1995; Shen et al., 1995; Wood \& Bath, 1988). Deste modo, a avaliação da redução da viscosidade de um meio contendo $\mathrm{CMC}$, juntamente com a avaliação da produção de somente celobiose a partir da degradação de celulose microcristalina são ensaios que caracterizam as celulases como endoglicanases ou celobiohidrolases.

Assim, a enzima Xf - 818 pode ser considerada como endoglicanase com atividade exoglicolítica, mas não uma endoglicanase/celobiohidrolase como a enzima caracterizada por Kim (1995), pois não forma exclusivamente celobiose a partir de celulose microcristalina (Figura 27). Kim (1995) denomina esta enzima como endo- $\beta$-1,4-D-glicanase I (Avicelase I), uma celulase com clivagem endo, embora hidrolise Avicel (celulose microcristalina). A Avicel é uma preparação de celulose relativamente heterogênea obtida de 
fibras de madeira através de hidrólise ácida parcial seguida de secagem ao ar. Contém componentes cristalinos e componentes desordenados (paracristalinos ou amorfos) resultando em cristalinidade de cerca de $50 \%$. As dimensões das fibras de celulose e a proporção de regiões cristalinas e amorfas dependem da sua origem e as fibras de celulose nas paredes celulares de plantas superiores são complexadas com hemiceluloses e lignina (Raven et al., 1976; Goodman et al., 1986). Assim, é esperada a ação conjunta, sinérgica e seqüencial de enzimas que atuem sobre estes polímeros, bem como a degradação de hemiceluloses (xilanas) pelas celulases, devido a similaridade estrutural da celulose e xilana.

Estas características são marcantes para uma endoglicanase com alta capacidade de hidrolisar CMC. Estes dados de alta atividade e diversidade na especificidade mostram que Xf - 818 é ativa sobre celulose e como o gene é expresso em $X$. fastidiosa (Scarpari, 2001) pode ser um fator de virulência ou agressividade empregado pela bactéria. Estes dados suportam a hipótese aqui apresentada, onde $X$. fastidiosa empregaria exoenzimas para degradar a membrana da pontuação, permitindo a dispersão radial da bactéria. Entretanto, ainda é necessária a confirmação experimental da expressão da enzima na interação com a planta e a demonstração da degradação da parede (membrana da pontuação) pela celulase.

A importância da manutenção de enzimas com atividades redundantes pode advir do sistema regulatório destas enzimas, sendo diferencialmente expressas ou ainda atuando de maneira sinérgica ou seqüencial "in planta", na degradação dos componentes da parede celular vegetal.

$\mathrm{O}$ fato das celulases Xf $-810, \mathrm{Xf}-818$ e Xf - 2708 não estarem purificadas não invalida os dados aqui apresentados, preclude entretanto a comparação de dados quantitativos, mas não qualitativos. Diversos estudos podem ser feitos mesmo se as proteínas não estiverem em estado puro, existindo exemplos com celulases de bactérias fitopatogênicas. Zhou \& Ingram (2000) caracterizaram a hidrólise sinérgica e seqüencial pelas endoglicanases CelY e CelZ obtidas de lisados de E. coli expressando estas enzimas. Gilkes et al. (1984) caracterizaram duas endoglicanases e uma celobiohidrolase de $C$. fimi obtidas de lisado bruto 
de E. coli expressando individualmente estas enzimas. Posteriormente, a atividade destas enzimas foi caracterizada com a proteína purificada, donde mostrou-se em concordância com os dados apresentados por Gilkes et al. (1984).

A celulase CelA (Família 5) de E. c. carotovora (Park et al., 1998) apresenta $\mathrm{pH}$ ótimo próximo a 7 e é mais ativa entre 40 e $50{ }^{\circ} \mathrm{C}$. CelY de E. chrysanthemi tem pH ótimo de 5,5 (Boyer et al., 1987a). CelS de E. carotovora é ativa sobre xilana e fracamente ativa em celulose microcristalina (Saarilahti et al., 1990) e CelS e CelZ tem pH ótimo a 6,8 e 7,0, respectivamente. A endoglicanase caracterizada por Nankai et al. (1999) apresenta baixa atividade em CMC e pH ótimo próximo a 6. As celulases de X. fastidiosa são mais ativas em pH ácido, o que pode estar relacionado ao ambiente xilemático.

As endoglicanases CelZ e CelY produzidas por Erwinia chrysanthemi possuem sinergia na degradação de celulose. Para que ocorra sinergismo, é necessária a atuação primária de CelY a CelZ. Embora CelY (família 8) seja responsável por somente 5 \% da degradação total de CMC, esta enzima não hidrolisa celooligossacarídeos e não produz produtos solúveis pela hidrólise de celulose amorfa. Ao contrário, CelZ (família 5) hidrolisa substratos de longa cadeia e celooligossacarídeos solúveis. Dessa forma, a incubação prévia do substrato com CelZ inabilita-o como substrato acessível a CelY. O aumento da atividade de CelZ no substrato modificado por CelY, é provavelmente o resultado do incremento na taxa de produção de substratos menores e rapidamento difusíveis. CelZ apresenta DLC e é secretada pelo mecanismo tipo II (Zhou \& Ingram, 2000). Funcionalmente, CelZ (E. chrysanthemi) e Xf - 818 apresentam similaridades, embora não tenha sido observado sinergia entre as celulases de $X$. fastidiosa (Tabela 11).

Fry et al. (1994) observaram a produção de duas proteases por X. fastidiosa PD, mas sua função na patogênese ou mais especificamente, na degradação de componentes da parede celular vegetal não foi avaliada ou comprovada. Por outro lado, a protease de $X$. $c$. pv. campestris degrada proteína da parede celular (Dow et al., 1998). Scarpari (2001) detectou a presença de RNAm do gene Xf - 818 em culturas de X. fastidiosa crescidas "in vitro", o que é um indício da produção de celulases no meio de cultura, diferentemente da $X$. 
fastidiosa PD. Hopkins (1985) não detectou a produção de enzimas degradadoras da parede celular em $X$. fastidiosa PD, sugerindo a incapacidade de degradar os componentes da parede celular da videira. Entretanto, a bactéria pode produzir tais enzimas quando em contato com o hospedeiro.

Além da possibilidade do envolvimento das celulases na degradação da parede celular vegetal em citros, esta enzima pode participar da dinâmica de formação e deslocamento do biofilme produzido por X. fastidosa, pois Nankai et al. (1992) observaram que uma celulase apresenta a capacidade de degradar a estrutura composta de glicose $\beta-1,4$ presente na goma xantana, embora seja ativa somente após a ação de uma liase. Assumindo que $X$. fastidiosa produz biofilmes nos vasos xilemáticos de citros (Leite et al., 2002; Marques et al., 2002) e que a colonização de novos vasos requer o deslocamento das células que compõe o biofilme, podemos imaginar que $X$. fastidiosa produz PSE ou a goma fastidiana (Silva et al., 2001) envolvidos na formação do biofilme e que as celulases e outras enzimas produzidas pela bactéria participam da desestruturação do biofilme. Esta desestruturação permite que as células sejam transportadas para novos locais (Leite et al., 2001) ou seja, novos vasos do xilema.

Foram observadas diferenças marcantes na morfologia do biofilme e formação de agregados de células entre os isolados de videira, elmo e amendoeira e aqueles de laranjeira e cafeeiro, ou grupo CVC (Marques et al., 2002). Os autores observaram que o grupo CVC caracteriza-se pela formação de agregados em culturas líquidas estáticas, não aderência ao vidro e uma fraca tendência para a formação de biofilmes abundantes nas condições testadas. A organização do biofilme no grupo CVC caracteriza-se pelas células mais dispersas e usualmente envoltas por grande quantidade de matriz exopolimérica secretada pela células. As diferenças entre a morfologia do biofilme e adesão a superfícies nestes dois grupos, sugere a possível seleção para adaptação a um hospedeiro em particular (Marques et al., 2002).

Fry \& Milholland (1990b) descrevem as cultivares de videira suscetíveis a $X$. fastidiosa, como incapazes de localizar o patógeno em reações de defesa caracterizadas por menor proporção de tiloses, gomas e principalmente de pectinas. Isto permitiria a dispersão da 
bactéria através dos vasos, incitando novas reações de defesa, i.e., produção de pectina, as quais somadas seriam as grandes responsáveis pelo surgimento dos sintomas de estresse hídrico na planta. Em cultivares resistentes, as respostas de defesa consistem principalmente de tilose e gomas (Mollenhauer \& Hopkins, 1976) ou preferecialmente tiloses (Fry \& Milholland, 1990b), as quais são efetivas em restringir a dispersão do patógeno. Entretanto, em citros não foram feitos estudos com este objetivo até o momento, mas Almeida (2001) observou ao menos um grupo de proteínas provavelmente de origem vegetal, que possa estar envolvida na interação Xylella - citros. O fluído intercelular de laranjeira infectada com X. fastidiosa foi analisado através de eletroforese bidimensional, onde foi observada a predominância de proteínas ácidas no fluído intercelular (Almeida, 2001). Embora até aquele momento não tenham sido identificadas proteínas bacterianas com expressão diferencial em plantas infectadas com X. fastidiosa, Almeida (2001) observou cinco isoformas de uma proteína de $41 \mathrm{kDa}$ com pI entre 4,2 e 5,0, em folhas de citros infectadas, com ou sem sintomas de CVC, provalmente de uma proteína vegetal, visto a seqüência $\mathrm{N}$-terminal (idêntica para todas isoformas) não apresentar similar em Xylella. O mesmo autor observou que o proteoma do fluído intercelular de plantas de diferentes localidades são distintos, independente da presença de X. fastidiosa ou sintomas de CVC.

Embora estudos ultraestruturais não tenha sido realizados em citros com CVC, determinados hospedeiros são resistentes devido à ocorrência de vasos curtos e menores do que os encontrados em variedades suscetíveis. A resistência da cana-de-açúcar a Leifsonia xyli ssp. xyli, bactéria limitada ao xilema causadora do raquitismo da soqueira, está relacionada com a arquitetura do sistema vascular. Na planta resistente os elementos de vaso são mais ramificados e não se extendem além dos internodos (Teackle et al., 1975).

Outra característica diferencial entre as linhagens de $X$. fastidiosa de diferentes hospedeiros é a taxa de transmissão pelos insetos vetores. Esta taxa é baixa para Xylella de citros (1 a $12 \%$ ) (Krügner et al., 1998) quando comparada com um vetor eficiente da $X$. fastidiosa PD (Purcell \& Finlay, 1979). Mizubuti et al., (1994) observaram que 5 a $10 \%$ dos vasos do xilema de folhas de laranja sintomáticas estavam colonizados pela $X$. fastidiosa, onde 
o lúmen estava totalmente obstruído ou apresentava células cobrindo as paredes celulares. Pascholati et al. (2002) também observaram um número semelhante de vasos colonizados em citros. Este índice de colonização é menor do que a observada para a linhagem causadora de "almond leaf scorch", de 10 a $15 \%$ (Mirmetich et al., 1976), de até $18 \%$ no caso de $X$. fastidiosa PD (Hopkins \& Thompson, 1984) e 26 a $51 \%$ em cafeeiro, com sintomas leves e intenso, respectivamente (Pascholati et al., 2002). Estes trabalhos evidenciam que no patossistema videira - Xylella, os vetores (relação patógeno - vetor) são mais eficientes na transmissão ou aquisição da bactéria, quando comparado ao patossistema laranjeira - Xylella. Devemos considerar que os vetores em videira têm maior probabilidade de adquirirem a $X$. fastidiosa PD pois há um maior número de vasos do xilema com a bactéria (Hopkins \& Thomson, 1984) e o biofilme formado por estas linhagens pode ser mais extenso em videira (Marques et al., 2002). O recente seqüenciamento de ambos patógenos (Simpson et al., 2000; http://watson.fapesp.br/onsa/Genoma3.htm), e de outras linhagens de X. fastidiosa (Bhattacharyya et al., 2002), podem fornecer informações a respeito dessas diferenças de colonização e transmissão, caso elas não sejam características intrínsecas aos hospedeiros e vetores.

Os dados apresentados acima são intrigantes: baixa eficiência de transmissão por vetores, menor taxa de colonização dos vasos do xilema e não propensão à formação de biofilmes extensos. Entretanto, a eficiência do patógeno pode ser comprovada pela incidência de CVC observada nos pomares de laranjeira no estado de São Paulo. Certamente neste caso, a presença humana favoreceu a dispersão da bactéria, através da distribuição de mudas infectadas com $X$. fastidiosa. Obviamente, o conhecimento que detemos a respeito da biologia das bactérias fitopatogênicas é pequeno frente à gama de mecanismos e interações que estas estabelecem com as plantas hospedeiras. Por exemplo, supõe-se que os sintomas da CVC sejam causados pela oclusão dos vasos xilemáticos, interferindo na circulação de seiva e água. A observação mais óbvia a ser esperada seria a formação de biofilmes ou agregados extensos pela linhagem causadora de CVC. O que Marques et al. (2002) observaram foi que X. fastidiosa CVC não forma biofilmes tão extensos quanto os formados pela linhagem 
causadora da doença de Pierce em videira. Ademais, X. fastidiosa CVC infecta uma baixa porcentagem de vasos do xilema e seus vetores são ineficientes para transmiti-las a outras plantas. Por outro lado, podemos supor que a não formação de biofilmes extensos vem a favorecer a transmissão pelos vetores, pois otimizaria a possibilidade da bactéria ser transportada pelo sistema vascular para um maior número de vasos, aumento a chance de um vetor sugar o xilema e transmiti-la a outras plantas.

As funções dos genes homólogos ao operon gum de $X$. compestris pv. campestris e genes rpf foram enfocadas por Dow \& Daniels (2000), Lambais et al. (2000), Silva et al. (2001), além das considerações discorridas por Simpson et al. (2000). A despeito de toda controvérsia a respeito do possível papel dos PSE nos sintomas da CVC, principalmente levando-se em consideração a presença do operon da goma fastidiana em $X$. fastidiosa (Silva et al., 2001), dados experimentais não estão disponíveis para suportar tal hipótese. A mesma assunção foi levada em consideração em relação a Clavibacter michiganensis, uma bactéria fitopatogênica Gram-positiva, que coloniza os vasos xilemáticos, produz PSE e causa murcha na planta hospedeira. Entretanto, mutantes que produzem somente $10 \%$ dos PSE são indistinguiíveis do tipo selvagem em relação à indução de sintomas na planta hospedeira (Jahr et al., 1999). O mutante celA- de C. m. sepedonicus não foi tão agressivo em berinjela quanto o selvagem (Laine et al., 2000), enquanto em $C$. $m$. michiganensis (Meletzus et al., 1993 e Jahr et al., 2000) CelA é necessária para a patogênese em tomate. Entretanto, somente este gene não parece ser suficiente para a bactéria incitar os sintomas em tomate. O gene pat-1, localizado em plasmídio distinto ao qual localiza-se celA, está presente em todas as linhagens virulentas da bacéria (Jahr et al., 1999). CelA de C. m. michiganensis (Jahr et al., 2000) e C. m. sepedonicus (Laine et al., 2000) contém um domínio C-terminal $\left(3^{\circ}\right.$ domínio) que apresenta baixa similaridade de sequiência com expansinas vegetais e com a celulase Xf - 810 de $X$. fastidiosa. Expansinas são proteínas que associam-se à parede celular vegetal, favorecendo sua elongação (Cosgrove, 2001).

A mesma dúvida a respeito da importância das celulases na patogênese pode ser inferida. Em geral, mutantes que não produzem uma dada celulase são capazes de causar 
doença na planta hospedeira ou são levemente afetados nesta capacidade. Em $X$. c. pv. campestris, a endoglicanase extracelular EngXCA de $53 \mathrm{kDa}$ é importante nos primeiros estágios da patogenicidade em nabo e rabanete, onde a bactéria mutante apresenta a mesma taxa de crescimento que a linhagem selvagem, mas os sintomas demoram um dia a mais para surgirem (Gough et al., 1988; Gough et al., 1990). R. solanacearum deficiente na produção de celulase $\left(\mathrm{egl}^{-}\right)$demora mais a incitar sintomas no hospedeiro (Roberts et al., 1988).

E. chrysanthemi 3937 produz duas celulases: CelZ é responsável por $95 \%$ da atividade celulásica (Boyer et al., 1987a) e o mutante celZ ${ }^{-}$incita sintomas da mesma maneira que o organismo selvagem em folhas de Saintpaulia ionantha (Boccara et al., 1994); por sua vez CelY responde por $5 \%$ da atividade celulásica (Boyer et al., 1987a; Guiseppi et al., 1991), entretanto o mutante $c e l Y^{-}$incita sintomas com três dias de atraso em relação ao tipo selvagem (Boccara et al., 1994), relacionando a função da enzima e o seu efeito sinérgico com CelZ (Zhou \& Ingram, 2000).

E. chrysanthemi possui linhagens que causam doença em milho. As monocotiledôneas têm maior porcentagem de hemiceluloses (30 a $40 \%$ de arabinoxilana e somente traços de xilogicana) nas paredes que as dicotiledôneas, Entretanto, uma linhagem de E. chrysanthemi isolada de milho produz duas xilanases, mas os genes que codificam estas xilanases, $\operatorname{bgxA}$ e $x y n A$, não são essenciais para que a bactéria cause sintomas em folhas de milho (Keen et al., 1996; Vroemen et al., 1995).

E. carotovora ssp. carotovora SCC3193 possui a celulase CelV (Cooper \& Salmond, 1993), que é a principal responsável pela atividade celulásica, CelV1 (Mäe et al., 1995) e CelS (Saarilahti et al., 1990). CelV é extracelular e importante para a virulência da bactéria (Walker et al., 1994; Mäe et al., 1995). Park et al., (1998) clonaram a celulase celA de E. c. ssp. carotovora LY34, similar a CelV da linhagem SCC3193. A presença de enzimas múltiplas pode permitir uma estratégia regulatória mais complexa e a degradação da celulose em ambientes diversificados, ou simplesmente permitir altos níveis de produção de celulase através do aumento da dosagem gênica (Park et al., 1998). Também, a ação das 
celulases pode permitir que outros polissacarídeos fiquem acessíveis ou suscetíveis à hidrólise pelas outras EDPCV.

A capacidade de hidrolisar a celulose a oligossacarídeos solúveis está relacionada à capacidade da bactéria em utilizar os produtos desta hidrólise. E. chrysanthemi apresenta um sistema fosfotransferase (PTS) dependente de fosfoenolpiruvato que transporta celobiose e celotriose produzidos pela ação de CelZ para o interior da célula (El Hassouni et al., 1992). A celobiose e possivelmente a celotriose, são hidrolizados pela fosfo- $\beta$-glicosidase citoplasmática e os produtos resultantes, glicose e glicose 6 fosfato entram na glicólise. A absorção de celobiose e celotriose minimizaria a dispersão de glicose e a competição com outros microrganismos que utilizam somente o monômero glicose (Zhou \& Ingram, 2000). X. fastidiosa 9a5c possui uma $\beta$-glicosidase (Simpson et al., 2000; Xf - 439) que podeira clivar glicose a partir de extremidades não-redutoras de celooligossacarídeos e parece possuir um sistema PTS que tipicamente medeia a absorção de pequenos carboidratos. Entretanto, um gene com similaridade à permease encontrada nestes sistemas não foi observada em $X$. fastidiosa (Simpson et al., 2000), o que entretanto, não exclui a presença desse gene.

No genoma da $X$. fastidiosa, encontramos genes com similaridade a genes que codificam pilos do tipo IV (Lambais et al., 2000). Estes genes codificam proteínas estruturais que formam estes pilos, sendo que estas estruturas efetuam a movimentação da bactéria sobre superfícies sem a utilização de flagelos, em movimentos conhecidos como "twitching motility". Os pilos são polares e também participam na interação célula a célula, patogênese, formação de biofilme, etc. Sua proteínas constituintes apresentam extremidade N-terminal conservada e, em muitas infecções bacterianas, atuam como adesinas (Wall \& Kaiser, 1999). Em R. albus, existe uma proteína com domínio característico da proteína pili do tipo IV e que apresenta capacidade de ligação à celulose (Pegden et al., 1998). De qualquer maneira vem a ser uma possibilidade a função de pilos do tipo IV, localizados polarmente, serem os responsáveis por determinado grau de aderência à celulose e até mesmo apresentarem papel na motilidade, interação célula a célula e formação de biofilme. Devemos lembrar que Chagas et al. (1992) observaram estruturas fibrilares em amostras de tecido vegetal infectado com X. fastidiosa. 
A geração de mutantes, através de recombinação homóloga (Monteiro et al., 2001b; Gaurivaud et al., 2002) e mutagênese aleatória empregando transposon (Guilhabert et al., 2001), permitindo a geração de grande número de mutantes, certamente fornecerá informações valiosas a respeito da patogenicidade de $X$. fastidiosa. A caracterização destes mutantes deve ser criteriosa quanto a inferências da função dos genes, na patogenicidade em hospedeiros alternativos. Embora o fumo seja um hospedeiro bastante viável (Lopes et al., 2000), assim como a vinca (Monteiro et al., 2001a), a caracterização de um mutante deverá também ser confirmada em citros. Os fatores de patogenicidade ou virulência podem ter alvos específicos, sendo o resultado de sua ação diferente em hospedeiros distintos. Uma simples extrapolação pode ser observada pelos sintomas diferenciados incitados pela $X$. fastidiosa CVC em citros e em fumo (Lopes et al., 2000).

A geração de anticorpos para as celulases de $X$. fastidiosa poderá representar uma poderosa ferramenta para se avaliar a produção dessas enzimas em variadas condições ambientais, como a formação de biofilmes, condições de crescimento diferenciadas e principalmente "in planta", nos tecidos do hospedeiro. 


\section{CONCLUSÕES}

Com base nos resultados apresentados, podemos concluir que:

Os genes de $X$. fastidiosa 9a5c Xf - 810, Xf - 818 e Xf - 2708 apresentam similaridade a genes de endoglicanases e as proteínas codificadas apresentam atividade enzimática celulásica, mais especificamente de endoglicanases (EC 3.2.1.4).

As endoglicanases Xf $-810, \mathrm{Xf}-818$ e Xf -2708 degradam substratos poliméricos como a carboximetil celulose, celulose microcristalina e xilana "Birchwood". A capacidade de hidrolisar substratos solúveis, os oligossacarídeos derivados de celulose celotetraose e celopentaose, foi restrita a endoglicanase Xf - 818. Esta proteína também apresenta a capacidade de ligação a celulose microcristalina.

As endoglicanases Xf -810, Xf -818 e Xf - 2708 degradam mais eficientemente a carboximetil celulose em pH ácido, entre 5,2 e 5,6, na temperatura de $65^{\circ} \mathrm{C}$.

As proteínas recombinantes contendo cauda hexahistidina não puderam ser purificadas através de cromatografia por afinidade em metal, em etapa única.

Desenvolvemos uma procolo empregando cromatografia de troca aniônica, afinidade por metal (níquel) e filtração em gel eficiente para a purificação da endoglicanase Xf 818. 
ANEXOS 


\section{ANEXO A - Extração de DNA plasmidial em pequena escala ("Mini-Prep").}

Centrifugar 1,5 mL de meio de cultura com a cultura bacteriana ( $2 \mathrm{~min} / 9300 \mathrm{~g}$ )

$\downarrow$

Ressuspender o pelete em $100 \mu \mathrm{L}$ de solução I gelada (vórtex)

Adicionar $200 \mu \mathrm{L}$ da solução II (misturar suavemente por inversão e deixar em gelo por 5 min) $\downarrow$

Adicionar $150 \mu \mathrm{L}$ da solução III gelada. Misturar delicadamente (deixar no gelo por $5 \mathrm{~min}$ )

$$
\text { Centrifugar (5 min / } 15700 \mathrm{~g} \text { ) }
$$

$\downarrow$

Opcional : tratar o sobrenadante com 1,5 $\mu \mathrm{L}$ de RNAse $\left(10 \mathrm{mg} \mathrm{mL}^{-1}\right)\left(20 \mathrm{~min} / 37^{\circ} \mathrm{C}\right)$ $\downarrow$

Adicionar igual volume de fenol equilibrado:clorofórmio:álcool isoamílico (24:24:1 v/v/v).

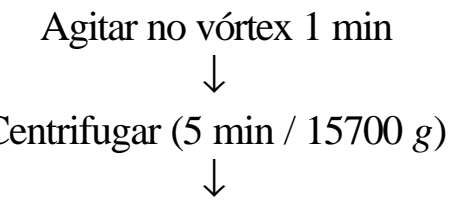

Transferir a fase aquosa (superior) para um novo tubo e adicionar igual volume de clorofórmio:álcool isoamílico $(24: 1 \mathrm{v} / \mathrm{v})$. Agitar no vórtex $30 \mathrm{~s}$

$\downarrow$

Transferir a fase aquosa para tubo novo e adicionar 2,5 volumes te etanol absoluto $20^{\circ} \mathrm{C}$ (misturar e deixar a $-20^{\circ} \mathrm{C} / 5 \mathrm{~min}$ )

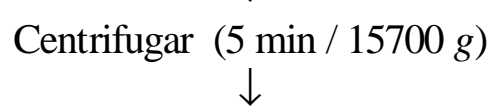

Lavar o pelete com etanol $70 \%$ gelado

$\downarrow$

Secar o pelete

$\downarrow$

Ressucpender o pelete em água ultrapura esterilizada ou Tris- $\mathrm{HCl} 5 \mathrm{mM}$

Nos itens 3.3.3 e 3.3.4.1 foi utilizado o protocolo descrito acima. Em 3.3.4.2

e 3.3.5 foram suprimidas as etapas que empregam fenol:clorofórmio:álcool isoamílico e clorofórmio:álcool isoamílico, sendo o sobrenadante obtido após adição da solução III misturado diretamente com o etanol absoluto. O restante do processo foi o mesmo descrito acima. 


\section{Solução I}

Glicose........................... $50 \mathrm{mM}$

EDTA pH 8,0................ 10 mM

Tris- $\mathrm{HCl} \mathrm{pH} \mathrm{8,0} \mathrm{............} 25 \mathrm{mM}$

\section{Solução II}

$\mathrm{NaOH} 1 \mathrm{M}$................... 100 mM

$\operatorname{SDS}^{1} 20 \%$

\section{Solução III}

Acetato de potássio $3 \mathrm{M}$, pH 5,2 ajustado com ácido acético glacial; manter no refrigerador $\left(4{ }^{\circ} \mathrm{C}\right)$.

$1-\mathrm{SDS}=$ dodecilsulfato de sódio 


\section{ANEXO B - Limpeza do DNA amplificado da PCR.}

Reação de amplificação da PCR $( \pm 100 \mu \mathrm{L})+$

$10 \mu \mathrm{L}$ acetato de sódio (3 M pH 5,5) gelado +

$220 \mu \mathrm{L}$ de etanol puro gelado

$\downarrow$

Homogeneizar e manter $\mathrm{a}-20{ }^{\circ} \mathrm{C}$ no mínimo $2 \mathrm{~h}$

$\downarrow$

Centrifugar $15 \mathrm{~min} / 15700 \mathrm{~g}$

$\downarrow$

Pelete $+200 \mu \mathrm{L}$ de etanol $70 \%$ gelado

$\downarrow$

Centrifugar $10 \mathrm{~min} / 15700 \mathrm{~g}$

$\downarrow$

Secar o pelete e dissolver em água ou Tris- $\mathrm{HCl} 5 \mathrm{mM}$ pH 8,0 


\section{ANEXO C - Extração de DNA do gel de agarose.}

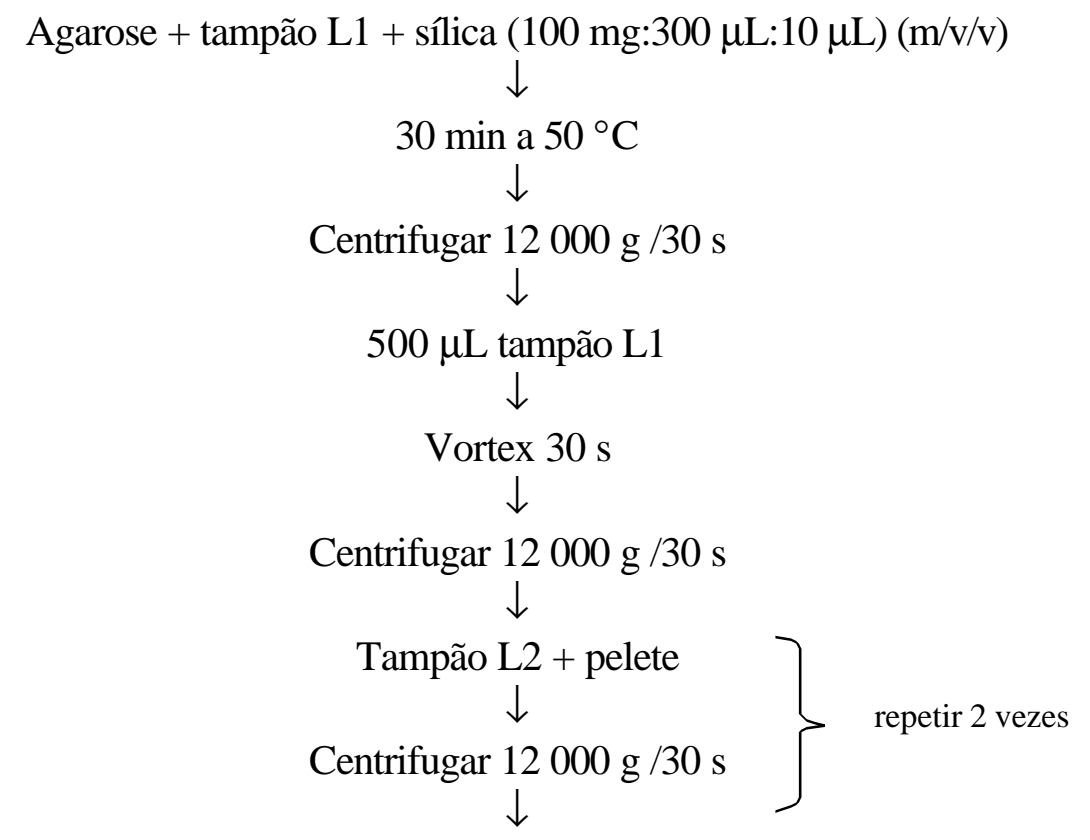

Secar o pelete e dissolver em $20 \mu \mathrm{L}$ de Tris- $\mathrm{HCl} 5 \mathrm{mM}$, $\mathrm{pH} 8,0$

$\downarrow$

Centrifugar $12000 \mathrm{~g} / 30 \mathrm{~s}$

$\downarrow$

Recolher o sobrenadante

Referência: "Gel Extraction Protocol" - Concert"TM (11457-017 - "Gibco BRL/Life Technologies"). 


\section{ANEXO D - Dessalinização da reação de ligação.}

a) Preencher um microtubo de centrífuga com 1,3 $\mathrm{mL}$ de solução de glicose $100 \mathrm{mM}$ e agarose $1 \%(\mathrm{~m} / \mathrm{v})$ preparada em água ultrapura. Com a solução ainda fundente, inserir uma ponteira de $200 \mu \mathrm{L}$ através de um orifício feito na tampa do microtubo até cerca de $2 / 3$ da profundidade do tubo;

b) Após a agarose solidificar, retira-se a ponteira. Fecha-se o microtubo e deposita-se o mesmo em gelo;

c) Adiciona-se a ligação na cavidade formada pela ponteira no gel de agarose e mantem-se o microtubo durante 90 min no gelo;

d) Retira-se o líquido da cavidade com o auxílio de uma pipeta, o qual pode se utilizado para a transformação. 


\section{ANEXO E - Purificação da PCR de seqüenciamento.}

Volume amplificado em na PCR $=10 \mu \mathrm{L}$

a) Adicionar $60 \mu \mathrm{L}$ de isopropanol $75 \%$ (preparado no momento de utilizar) ao volume de 10 $\mu \mathrm{L}$ da reação da PCR e agitar vigorosamente 20 vezes. Manter 20 min a temperatura ambiente;

b) Centrifugar 45 min a $2250 \mathrm{~g}$ a temperatura ambiente. Retirar o excesso invertendo a placa e centrifugar a placa invertida até atingir $140 \mathrm{~g}$ (velocidade de aceleração e freio em 1);

c) Lavar o pelete com $150 \mu \mathrm{L}$ de etanol $70 \%$ (a temperatura ambiente) e centrifugar 10 min a $2250 \mathrm{~g}$ (a temperatura ambiente);

d) Retirar o excesso invertendo a placa e centrifugar a placa invertida até aingir $140 \mathrm{~g}$ (velocidade de aceleração e freio em 1);

e) Secar o pelete no escuro a temperatura ambiente durante $2 \mathrm{~h}$. Armazenar em refrigerado (4 ${ }^{\circ} \mathrm{C}$ ) e no momento de seqüenciar adicionar $10 \mu \mathrm{L}$ de formamida e agitar. Desnaturar $5 \mathrm{~min}$ a $95^{\circ} \mathrm{C}$ antes de seqüenciar.

Este protocolo tem por objetivo retirar os sais do tampão bem como os nucleotídeos fluorescentes (cromóforos) não incorporados. Serve também para dissolver o DNA amplificado em solvente apropriado para o seqüenciamento. 
ANEXO F - Preparação de células de Escherichia coli eletrocompetentes (Sambrock et al., 1989).

a) Inocular uma colônia da linhagem de E. coli (DH5 $\alpha$, BL21(DE3) ou BL21(DE3)pLysS) crescida previamente em meio sólido, em 2,5 ml de meio de cultura LB. Incubar por 16 horas, a $37^{\circ} \mathrm{C}$ e $180 \mathrm{rpm}$;

b) Inocular estes $2,5 \mathrm{~mL}$ de cultura em $250 \mathrm{~mL}$ de meio $\mathrm{RB}$ aquecido a $37^{\circ} \mathrm{C}$, em Erlenmeyer de $1 \mathrm{~L}$. Crescer esta cultura $\left(37^{\circ} \mathrm{C}, 220 \mathrm{rpm}\right)$ até que a mesma apresente $\mathrm{OD}{ }_{550 \mathrm{~nm}}$ entre 0,4 a 0,6, o que geralmente ocorre após 2 a 3 h;

c) Transferir o meio de cultura para tubos de centrífuga esterilizados e manter no gelo. Centrifugar a $700 \mathrm{~g}$ por 5 minutos, a $4^{\circ} \mathrm{C}$;

d) Descartar o sobrenadante e ressuspender o pelete em 30 volumes de glicerol $10 \%$ estéril gelado;

e) Centrifugar a $700 \mathrm{~g}$ por 5 minutos, a $4^{\circ} \mathrm{C}$. Repetir as etapas d) e e) no mínimo 2 vezes;

f) Ressuspender o pelete em 1 a 2 gotas de glicerol $10 \%$ estéril gelado e aliquotar em microtubos novos e esterilizados, previamente resfriados a $-75^{\circ} \mathrm{C}$, colocando $50 \mu \mathrm{L}$ em cada tubo. Congelá-las em nitrogênio líquido e armazenar a $-75^{\circ} \mathrm{C}$. As células competentes devem ser testadas quanto a contaminação e eficiência de transformação. 


\section{ANEXO G - Eletroforese desnaturante em gel descontínuo de poliacrilamida.}

Os géis de poliacrilamida foram preparados na concentração indicada, seguindo as proporções abaixo descritas.

Gel Concentrador:

\begin{tabular}{lcc}
\hline Reagentes & \multicolumn{2}{c}{ Concentração Acrilamida + Bisacrilamida } \\
\cline { 2 - 3 } & $4 \% \mathrm{~T}$ & $4,5 \% \mathrm{~T}$ \\
\hline Tris-HCl pH 6,8 0,617 M & $0,5 \mathrm{~mL}$ & $0,5 \mathrm{~mL}$ \\
Acrilamida $30 \%(\mathrm{~m} / \mathrm{v})$ & $0,66 \mathrm{~mL}$ & $0,75 \mathrm{~mL}$ \\
$\mathrm{SDS}^{\mathrm{a}} 10 \%(\mathrm{~m} / \mathrm{v})$ & $66 \mu \mathrm{L}$ & $66 \mu \mathrm{L}$ \\
$\mathrm{APS}^{\mathrm{b}} 10 \%(\mathrm{~m} / \mathrm{v})$ & $33 \mu \mathrm{L}$ & $33 \mu \mathrm{L}$ \\
TEMED & $4 \mu \mathrm{L}$ & $4 \mu \mathrm{L}$ \\
Água ultrapura & $3,74 \mathrm{~mL}$ & $3,65 \mathrm{~mL}$ \\
Volume (mL) & 5 & 5 \\
\hline a - dodecilsulfato de sódio & & \\
b - persulfato de amônio & &
\end{tabular}

Gel Separador:

\begin{tabular}{lccc}
\hline Reagentes & \multicolumn{3}{c}{ Concentração Acrilamida + Bisacrilamida } \\
\cline { 2 - 4 } & $10 \% \mathrm{~T}$ & $12,5 \% \mathrm{~T}$ & $15 \% \mathrm{~T}$ \\
\hline Tris-HCl pH 8,9 3,778 M & $1,0 \mathrm{~mL}$ & $1,0 \mathrm{~mL}$ & $1,0 \mathrm{~mL}$ \\
Acrilamida 30\% (m/v) & $3,34 \mathrm{~mL}$ & $4,17 \mathrm{~mL}$ & $5,0 \mathrm{~mL}$ \\
SDS 10\% (m/v) & $0,67 \mathrm{~mL}$ & $0,67 \mathrm{~mL}$ & $0,67 \mathrm{~mL}$ \\
APS 10 \% (m/v) & $33,4 \mu \mathrm{L}$ & $33,4 \mu \mathrm{L}$ & $33,4 \mu \mathrm{L}$ \\
TEMED & $4 \mu \mathrm{L}$ & $4 \mu \mathrm{L}$ & $4 \mu \mathrm{L}$ \\
Água ultrapura & $4,96 \mathrm{~mL}$ & $4,13 \mathrm{~mL}$ & $3,32 \mathrm{~mL}$ \\
Volume (mL) & 10 & 10 & 10 \\
\hline
\end{tabular}

Após polimerização, as canaletas foram lavadas com água destilada e preenchidas com tampão de corrida. A eletroforese foi efetuada em equipamento para eletroforese vertical Protean II ou mini-protean II (Bio-Rad, Califórnia - USA) em câmara fria, 
sob $4{ }^{\circ} \mathrm{C}$. Após o corante azul de bromofenol ter migrado para fora do gel pela superfície inferior, o gel foi retirado da forma e corado ou revelado para celulases.

Bis/Acrilamida $(30 \% ; \mathrm{m} / \mathrm{v})$

Acrilamida $30 \mathrm{~g}$

N'N'metileno bis-acrilamida $0,8 \mathrm{~g}$

Água ultra pura (Milli-Q) q.s.p. $100 \mathrm{~mL}$

Filtrar em filtro Millipore $45 \mu \mathrm{m}$ e armazenar a $4^{\circ} \mathrm{C}$.

Tampão da amostra para proteínas desnaturadas (SDS - PAGE) (Cannon-Carlson \& Tang, 1997).

Fosfato de sódio pH 7,0 $62,5 \mathrm{mM}$

Glicerol (v/v) $10 \%$

$\operatorname{SDS}(\mathrm{m} / \mathrm{v})$ $2 \%$

$\beta$-mercaptoetanol (v/v) $5 \%$

Azul de bromofenol (m/v) $0,001 \%$

Tampão do Tanque/Corrida (Alfenas et al., 1991)

Tris

Glicina

$\operatorname{SDS}(\mathrm{m} / \mathrm{v})$

pH 8,9

Armazenar em refrigerador $\left(4^{\circ} \mathrm{C}\right)$
$52 \mathrm{mM}$ $53 \mathrm{mM}$ $0,1 \%$ 


\section{ANEXO H - Coloração com azul de coomassie dos géis de eletroforese desnaturante para revelação de proteínas.}

A coloração de proteínas com azul de coomassie foi efetuada de acordo com a técnica de Roger Rowlett (http://www.nwfsc.noaa.gov/protocols/PAGE-destain.html ou http://tto.trends.com/tto/index_of_TTO.shtml sob número T01089):

a) Após a eletroforese, o gel é depositado em recipiente plástico (resistente a microondas) contendo $250 \mathrm{ml}$ de solução corante. Cobrir e submeter a microondas durante 2 a $3 \mathrm{~min}$ ou até que inicie fervura;

b) Manter o gel imerso no corante sob agitação, durante 15 a 60 min;

c) Remover a solução corante e lavar o gel e o recipiente com água destilada;

d) Cobrir o gel com 200 a $250 \mathrm{ml}$ de solução descorante e submeter a microondas durante 2 a 3 min ou até que inicie fervura;

e) Manter o gel imerso no corante sob agitação, durante 1 a 24 h. Para descoloração rápida, troque a solução descorante após 1 hora e repita a última operação. Três a quatro trocas são suficientes para visualização das bandas com pouco "background" $(3-4 \mathrm{~h}$ de descoloração).

\section{Solução corante}

Azul de Coomassie R-250 (m/v) ........... $1 \%$

Etanol $(\mathrm{v} / \mathrm{v})$........................................... $40 \%$

Ácido acético $(\mathrm{v} / \mathrm{v})$................................. $10 \%$

Dissolver o corante em $4 / 5$ do volume de etanol durante aproximadamente 1 hora sob agitação. Adicionar o ácido e completar o volume com água destilada. Armazenar em temperatura ambiente em frasco escuro.

\section{Solução descorante}

Etanol

$40 \%$

Ácido acético

$10 \%$ 


\title{
ANEXO I - Coloração com nitrato de prata dos géis de eletroforese desnaturante.
}

\author{
Eletroforese
}

$\Downarrow$

Transferir gel para bandeja plástica com $250 \mathrm{ml}$ de solução fixadora $15 \mathrm{~h}$

$$
\Downarrow
$$

Transferir o gel para $250 \mathrm{ml}$ de solução incubadora (15 min)

$\Downarrow$

Lavar o gel 3 vezes com água deionizada (10 min cada, sob agitação constante)

$\Downarrow$

Transferir o gel para a solução de prata (20 min)

$\Downarrow$

Transferir o gel para solução reveladora até o aparecimento das bandas

$\Downarrow$

Transferir para solução de parada (10 min)

$\Downarrow$

Lavar em água corrente (torneira) durante $2 \mathrm{~h}$

$\Downarrow$

Registrar ou fixar

\section{Solução Fixadora}

Etanol $40 \%$

Ácido acético $10 \%$

Preparar em água deionizada

\section{Solução incubadora}

Acetato de sódio $500 \mathrm{~mm}$

Etanol (v/v) $30 \%$

Tiossulfato de sódio $25 \mathrm{~mm}$ 
Glutaraldeído $25 \%$................... 0,108\%

Preparar em água deionizada e adicionar o glutaraldeído somente no momento de utilizar a solução. O tiossulfato de sódio é solúvel em água, insolúvel em álcool e decompõem em solução aquosa.

\section{Solução de Prata}

nitrato de prata $(\mathrm{m} / \mathrm{v}) \ldots \ldots \ldots \ldots \ldots . .5,5 \mathrm{mM}$

formaldeído ............................. 0,0037\%

Preparar em água ultrapura e adicionar o formaldeído somente no momento de utilizar a solução.

\section{Solução Reveladora}

carbonato de sódio (m/v) .......... 208 mM

formaldeído $0,0037 \%$

Preparar em água ultrapura e adicionar o formaldeído somente no momento de utilizar a solução.

\section{Solução de Parada}

EDTA $\mathrm{Na}$............................... 51,9 mM 


\section{ANEXO J - Preparação de celulose tratada com ácido.}

Dez gramas de Avicel são ressuspensas em $500 \mathrm{mM}$ de ácido fosfórico $\left(\mathrm{H}_{3} \mathrm{PO}_{4} 85 \%\right.$ m:v) e mantidas sob agitação por $1 \mathrm{~h} \mathrm{a} 4{ }^{\circ} \mathrm{C}$. Esta suspensão é misturada com 4 L de água gelada e mantida a $4{ }^{\circ} \mathrm{C}$. A Avicel amolecida é lavada 10 vezes com 2 litros de água destilada,através de decantação e então lavada com $2 \mathrm{~L}$ de $\mathrm{NaHCO}_{3} 1 \%(\mathrm{~m} / \mathrm{v})$. As lavagens com água são repetidas 10 vezes, e a suspensão resultante é decantada. O material particulado é retirado do decantado e a Avicel amolecida "acid swollen cellulose" é triturada em liquidificar caseiro em velocidade máxima durante $2 \mathrm{~min}$. $\mathrm{O}$ volume desta celulose amolecida é reduzido a 1/100 do volume original através de centrifuação (5 min $5000 \mathrm{~g} 4^{\circ} \mathrm{C}$ ) e novamente triturada em utra-turax durante 2 min na velocidade máxima. Esta celulose é armazenada a $4{ }^{\circ} \mathrm{C}$ com $\mathrm{NaN}_{3}$ a $0,05 \%$. Este protocolo é preparado de acordo com Wood \& Bath (1988), com pequenas modificações e a cadeia de Avicel resultante deve ser de aproximadamente 100 . 


\section{REFERÊNCIAS BIBLIOGRÁFICAS}

ALFENAS, A.C.; PETERS, I.; BRUNE, W.; PASSADOR, G.C. Eletroforese de proteínas e isoenzimas de fungos e essências florestais. Viçosa: Universidade Federal de Viçosa, 1991. 242p.

ALMEIDA, B.S.V. de. Análise do proteoma do fluído intercelular de folhas de laranjeiras infectadas com Xylella fastidiosa. Piracicaba, 2001. 59p. Dissertação (Mestrado) Escola Superior de Agricultura “Luiz de Queiroz", Universidade de São Paulo.

ALMEIDA, R.P.P.; PEREIRA, E.F.; PURCELL, A.H.; LOPES, J.R.S. Multiplication and movement of a citrus strain of Xylella fastidiosa within sweet orange. Plant Disease, v.85, n.4, p.382-386, 2001.

ALTSCHUL, S.F.; GISH, W.; MILLER, W.; MYERS, E.W.; LIPMAN, D.J. Basic local alignment search tool. Journal of Molecular Biology, v.215, n.3, p.403-410, 1990.

ALTSCHUL, S.F.; MADDEN, T.; SCHAFFER, A.; ZHANG, J.; MILLER, W.; LIPMAN, D.J. Gapped BLAST and PSI-BLAST: a new generation of protein database search programs. Nucleic Acids Research, v.25, n.17, p.3389-3402, 1997.

AMARO, A.A.; MAIA, M.L. Produção e comércio de laranja e de suco no Brasil. Laranja, v.18, n.1, p.1-26, 1997. 
AMORIM, L.; BERGAMIN FILHO, A.; PALAZZO, D.A.; BASSANEZI, R.B.; GODOY, C.V.; TORRES, G.A.M. Clorose variegada dos citros: uma escala diagramática para avaliação da severidade da doença. Fitopatologia Brasileira, v.18, n.2, p.174-180, 1993.

ASPINNAL, G.O. Chemistry of cell wall polysaccharides. In: STUMPF, P.K.; CONN, E.E. (Ed.). The biochemistry of plants: a comprehensive treatise. New York: Academic Press, 1980. cap.12, p.473-500.

AUSUBEL, F.M.; BRENT, R.; KINGSTON, R.E.; MOORE, D.D.; SEIDMAN, J.G.; SMITH, J.A.; STRUHL, K. Currents protocols in molecular biology. New Jersey: Wiley. 1998. 4v.

BAIRD, S.D.; HEFFORD, M.A.; JOHNSON, D.A.; SUNG, W.L.; YAGUCHI, M.; SELIGY, V.L. The Glu residue in the conserved Asn-Glu-Pro sequence of two highly divergent endo- $\beta-1,4$-glycanases is essential for enzymatic activity. Biochemistry and Biophysics Research Communications, v.169, n.3, p.1035-1039, 1990.

BARBER, C.E.; TANG, J.L.; FENG, J.X.; PAN, M.Q.; WILSON, T.J.; SLATER, H.; DOW, J.M.; WILLIAMS, P.; DANIELS, M.J. A novel regulatory system required for pathogenicity of Xanthomonas campestris is mediated by a small diffusible signal molecule. Molecular Microbiology, v.24, n.3, p.555-556, 1997.

BÉGUIN, P. Molecular biology of cellulose degradation. Annual Review of Microbiology, v.44, p.219-248, 1990.

BEKRI, M.A.; DESAIR, J.; KEIJERS, V.; PROOST, P.; SEARLE-VAN LEEUWEN, M.; VANDERLEYDEN, J.; VANDE BROEK, A. Azospirillum irakense produces a novel type of pectate lyase. Journal of Bacteriology, v.181, n.8, p.2440-2447, 1999. 
BELAICH, A.; FIEROBE, H.P.; BATY, D.; BUSETTA, B.; BAGNARATARDIF, C.; GAUDIN, C.; BELAICH, J.P. The catalytic domain of endoglucanase A from Clostridium cellulolyticum - effects of arginine-79 and histidine-122 mutations on catalysis. Journal of Bacteriology, v.174, n.14, p.4677-4682, 1992.

BERETTA, M.J.G.; BARTHE, G.A.; CECCARDI, T.L.; LEE, R.F.; DERRICK, K.S. A survey for strains of Xylella fastidiosa in citrus affected by citrus variegated chlorosis and citrus blight in Brazil. Plant Disease, v.81, n.10, p.1196-1198, 1997.

BERETTA, M.J.G.; CONTRERAS, J.; LEE, R.F.; CHAGAS, C.M.; MARMELICS, L.; DE NEGRI, J.; DERRICK, K.S. Similarity between citrus variegated chlorosis (CVC) in Brazil and Pecosita in Argentina. Summa Phytopathologica, v.18, n.1, p.54, 1992.

BERETTA, M.J.G.; HARAKAWA, R.; CHAGAS, C.M.; DERRICK, K.S.; BARTHE, G.A.; CECCARDI, T.L.; LEE, R.F.; PARADELA FILHO, O.; SUGIMORI, M.H.; RIBEIRO, I.J.A. First report of Xylella fastidiosa in coffee. Plant Disease, v.80, n.7, p.821, 1996.

BHATTACHARYYA, A.; STILWAGEN, S.; IVANOVA, N. et al., Whole-genome comparative analysis of three phytopathogenic Xylella fastidiosa strains. Proceeding of the National Academy of Sciences of USA, v.99, n.19, p.12403-12408, 2002.

BOCCARA, M.; AYMERIC, J.L.; CAMUS, C. Role of endoglucanases in Erwinia chrysanthemi 3937 virulence on Saintpaulia ionantha. Journal of Bacteriology, v.176, n.5, p.1524-1526, 1984.

BOHER, B.; NICOLE, M; POTIN, M.; GEIGER, J.P. Extracellular polysaccharides from Xanthomonas axonopodis pv. manihotis interact with cassava cell walls during pathogenesis. Molecular Plant Microbe Interactions, v.10, n.7, p.803-811, 1997. 
BOK, J.-D.; YERNOOL, D.A.; EVELEIGH, D.E. Purification, characterization, and molecular analysis of thermostable cellulases CelA and CelB from Thermotoga neapolitana. Applied and Environmental Microbiology, v.64, n.12, p.4774-4781, 1998.

BOUNIAS, M. N-(1-naphthyl)ethylenediamine dihydrochloride as a new reagent for nanomole quantification of sugars on thin-layer plates by a mathematical calibration process. Analytical Biochemistry, v.106, n.2, p.291-295, 1980.

BOYER, M.H.; CAMI, B.; CHAMBOST, J.-P.; MAGNAN, M.; CATTANÉO, J. Characterization of a new endoglucanase from Erwinia chrysanthemi. European Journal of Biochemistry, v.162, n.2, p.311-316, 1987a.

BOYER, M.H.; CAMI, B.; KOTOUJANSKY, A.; CHAMBOST, J.-P.; FRIXON, C.; CATTANÉO, J. Isolation of the gene encoding the major endoglucanase of Erwinia chrysanthemi: Homology between cel genes of two strains of Erwinia chrysanthemi. FEMS Microbiology Letters, v.41, n.3, p.351-356, 1987 b.

BRADFORD, M.M. A rapid and sensitive method for the quantitation of microgram quantities of protein utilizing the principle of protein-dye binding. Analytical Biochemistry, v.72, n.1-2, p.248-254, 1976.

BRAITHWAITE, K.L.; BLACK, G.W.; HAZLEWOOD, G.P.; ALI, B.R.; GILBERT, H.J. A non-modular endo-beta-1,4-mannanase from Pseudomonas fluorescens subspecies cellulosa. Biochemical Journal, v.305, part 3, p.1005-1010, 1995.

BRAUN, E.J.; RODRIGUES, C.A. Purification and properties of an endoxylanase from a corn stalk rot strain of Erwinia chrysanthemi. Phytopathology, v.83, n.3, p.332-338, 1993.

CANNON-CARLSON, S.; TANG, J. Modification of the Laemmli sodium dodecyl sulfate-polyacrylamide gel electrophoresis procedure to eliminate artifacts on reducing and nonreducing gels. Analytical Biochemistry, v.246, n.1, p.146-148, 1997.

CARVAlHO, M.L.V.; ROSSETTI, V.; POMPEU JR, J. Evolução da sintomatologia de clorose variegada dos citros em laranja doce (C. sinensis). Fitopatologia Brasileira, v.20, p.351, 1995. Suplemento. 
CHAGAS, C.M.; ROSSETTI, V.; BERETTA, M.J.G. Electron microscopy studies of a xylem-limited bacterium in sweet orange affected with citrus variegated chlorosis disease in Brazil. Journal of Phytopathology, v.134, n.4, p.300-312, 1992.

CHANG, C.J.; GARNIER, M.; ZREIK, L.; ROSSETTI, V.; BOVÉ, J.M. Culture and serological detection of the xylem-limited bacterium causing citrus variegated chlorosis and its identification as a strain of Xylella fastidiosa. Current Microbiology, v.27, n.3, p.137-142, 1993.

CHAPON, V.; CZJZEK, M.; HASSOUNI, M.E.; PY, B.; JUY, M.; BARRAS, F. Type II protein secretion in Gram-negative pathogenic bacteria: the study of the structure/secretion relationships of the cellulase Cel5 (formerly EGZ) from Erwinia chrysanthemi. Journal of Molecular Biology, v.310, n.5, p.1055-1066, 2001.

CONTRERAS, I Pecosita ou "Falsa mancha grascienta" na Argentina. Laranja \& Cia, v.31, n.6, p.10, 1992.

COOPER, V.J.; SALMOND, G.P. Molecular analysis of the major cellulase (CelV) of Erwinia carotovora: evidence for an evolutionary "mix-and-match" of enzyme domains. Molecular and General Genetics, v.241, n.3-4, p.341-350, 1993;

COSGROVE, D.J. Wall structure and wall loosening: a look backwards and forwards. Plant Physiology, v.125, n.1, p.131-134, 2001.

COUTINHO, P.M.; HENRISSAT, B. Carbohydrate-active enzymes: an integrated database approach. In: GILBERT, H.J.; DAVIES, G.; HENRISSAT, B.; SVENSSON, B. (Ed.). Recent advances in carbohydrate bioengineering. Cambridge: The Royal Society of Chemistry, 1999. p.3-12. 
CREUZET, N.; BERENGER, J.F.; FRIXON, C. Characterization of exoglucanase and synergistic hydrolysis of cellulose in Clostridium stercorarium. FEMS Microbiology Letters, v.20, n.3, p.347-350, 1993.

DAVIES, G.J.; WILSON, K.S.; HENRISSAT, B Nomenclature for sugar-binding subsites in glycosyl hydrolases. Biochemical Journal, v.321, part 2, p.557-559, 1997.

DAVIS, M.J.; PURCELL, A.H.; THOMSON, S.V. Isolation media for the Pierce's disease bacterium. Phytopathology, v.70, n.5, p.425-429, 1980.

DAVIS, M.J.; PURCELL, A.H.; THOMSON, S.V. Pierce's disease of grapevines: isolation of the causal bacterium. Science, v.199, n.4324, p.75-77, 1978.

DESHPANDE, M.V.; ERIKSSON, K-E.; PETTERSSON, L.G. An assay for selective determination of exo-1,4- $\beta$-glucanases in a mixture of cellulolytic enzymes. Analytical Biochemistry, v.138, n.2, p.481-487, 1984.

DIN, N.; FORSYTHE, I.J.; BURTNICK, L.D.; GILKES, N.R.; WARREN, R.A.J.; KILBURN, D.G. The cellulose binding domain of endoglucanase A (CenA) from Cellulomonas fimi: evidence for the involvement of tryptophan residues in binding. Molecular Microbiology, v.11, n.4, p.747-755, 1994.

DONADIO, L.D.; MOREIRA, C.S. Clorose variegada dos citros. Bebedouro: s. ed. 1997. 162p.

DOW, J.M.; DANIELS, M.J. Xylella fastidiosa genomics and bacterial pathogenicity to plants. Yeast, v.17, n.4, p.263-271, 2000.

DOW, J.M.; DAVIES, H.A.; DANIELS, M.J. A metalloprotease from Xanthomonas campestris that specifically degrades proline/hydroxyproline-rich glycoproteins of the plant extracellular matrix. Molecular Plant Microbe Interactions, v.11, n.11, p.1085-1093, 1998. 
DOW, J.M.; FAN, M.J.; NEWMAN, M.A.; DANIELS, M.J. Differential expression of conserved protease genes in crucifer attacking pathovars of Xanthomonas campestris. Applied and Environmental Microbiology, v.59, n.12, p.3996-4003, 1993.

DOW, J.M.; FENG, J.X.; BARBER, C.E. Novel genes involved in the regulation of pathogenicity factor production within the rpf gene cluster of Xanthomonas campestris. Microbiology, v.146, n.4, p.885-891, 2000.

EL HASSOUNI, M.; HENRISSAT, B.; CHIPPAUX, M.; BARRAS, F. Nucleotide sequences of the arb genes, which control $\beta$-glucoside utilization in Erwinia chysanthemi: comparison with the Escherichia coli bgl operon and evidence for a new $\beta$-glycohydrolase family including enzymes from eubacteria, archeabacteria, and humans. Journal of Bacteriology, v.174, n.3, p.765-777, 1992.

FEIL, H.; PURCELL, A.H. Temperature-dependent growth and survival of Xylella fastidiosa in vitro and in potted grapevines. Plant Disease, v.85, n.12, p.1230-1234, 2001 .

FERREIRA, H.; GONÇALVES, E.R.; RODRIGUES NETO, J.; ROSATO, Y.B. Primers specific for Xylella fastidiosa based on RAPD differential fragments. Summa Phytopathologica, v.26, n.1, p.15-20, 2000.

FINLAY, B.B.; FALKOW, S. Common themes in microbial pathogenicity revisited. Microbiology and Molecular Biology Reviews, v.61, n.2, p.136-169, 1997.

FONSECA, H.S.; FURTADO, E.L.; KURAMAE, E.E.; MACHADO, S.R.; MINHONI, M.A.T.; NOZAKI, D.N. Seringueira, um novo hospedeiro de Xylella fastidiosa no Brasil. Fitopatologia Brasileira, v.26, p.275, 2001. Suplemento.

FOONG, F.C.-F.; DOI, R.H. Characterization and comparison of Clostridium cellulovorans endoglucanases-xylanases EngB and EngD hyperexpressed in Escherichia coli. Journal of Bacteriology, v.174, n.4, p.1403-1409, 1992. 
FREITAG, J.H. Host range of the Pierce's disease virus of grapes as determined by insect transmission. Phytopathology, v.41, n.10, p.920-934, 1951.

FRENCH, W.I.; FELICIANO, A. Distribution and severity of plum leaf scald disease in Brasil. Plant Disease, v.66, n.6, p.515-517, 1982.

FRENCH, W.I.; STASSI, D.L. Response of phony-infected peach trees with gibberellic acid. Horticultural Science, v.13, n.2, p.158-159, 1978.

FRY, S.M.; HUANG, J.S.; MILHOLLAND, R.D. Isolation and preliminary characterization of extracellular proteases produced by strains of Xylella fastidiosa from grapevines. Phytopathology, v.84, n.4, p.357-363, 1994.

FRY, S.M.; MILHOLLAND, R.D. Multiplication and translocation of Xylella fastidiosa in petioles and stems of grapevine resistant, tolerant, and susceptible to Pierce's Disease. Phytopathology, v.80, n.1, p.61-65, 1990a.

FRY, S.M.; MILHOLLAND, R.D. Response of resistant, tolerant, and susceptible grapevines to invasion by the Pierce's disease bacterium, Xylella fastidiosa. Phytopathology, v.80, n.1, p.66-69, 1990b.

FUNDO DE DEFESA DA CITRICULTURA (FUNDECITROS). Estatísticas: clorose variegada dos citros. http://www.fundecitrus.com.br/ (02 jul. 2002)

GAURIVAUD, P.; SOUZA, L.C.A.; VIRGÍlIO, A.C.D.; MARIANO, A.G.; PALMA, R.R.; MONTEIRO, P.B. Gene disruption by homologous recombination in the Xylella fastidiosa citrus variegated chlorosis strain. Applied and Environmental Microbiology, v.68, n.9, p.4658-4665, 2002.

GEBLER, J.; GILKES, N.; CLAEYSSENS, M.; WILSON, D.B.; BÉGUIN, P.; WAKARCHUK, W.W.; KILBURN, D.G.; MILLER, R.C.Jr.; WARREN, R.A.J.; WITHERS, S.G. Stereoselective hydrolysis catalyzed by related $\beta$-1,4-glucanases and $\beta-1,4-x y l a n a s e s . \quad J o u r n a l$ of Biological Chemistry, v.267, n.18, p.12559-12561, 1992.

GILKES, N.R.; HENRISSAT, B.; KILBURN, D.G.; MILLER, R.C. Jr.; WARREN, R.A.J. Domains in microbial $\beta$-1,4-glycanases: sequence conservation, function, and enzyme families. Microbiological Reviews, v.55, n.2, p.303-315, 1991. 
GILKES, N.R.; LANGSFORD, M.L.; KILBURN, D.G.; MILLER, R.C.Jr.; WARREN, R.A.J. Mode of action and substrate specificities of cellulases from cloned bacterial genes. Journal of Biological Chemistry, v.259, n.16, p.10455-10459, 1984.

GOHEEN, A.C.; NYLAND, G.; LOWE, S.K. Association of a rickettsia-like organism with Pierce's disease of grapevine and alfalfa dwarf and heat terapy of the disease in grapevines. Phytopathology, v.63, n.3, p.341-345, 1973.

GOODMAN, R.N.; KIRÁLY, Z.; WOOD, K.R. The biochemistry and physiology of plant disease. Columbia: University of Missouri Press, 1986. 433p.

GOODNER, B.; HINKLE, G.; GATTUNG, S. et al. Genome sequence of the plant pathogen and biotechnology agent Agrobacterium tumefaciens C58. Science, v.294, n.5550, p.2323-2328, 2001.

GORDON, D.; ABAJIAN, C.; GREEEN, P. Consed: a graphical tool for sequence finishing. Genome Research, v.8, n.3, p.195-202. 1998.

GOTTWALD, T.R.; GIDTTI, F.B.; SANTOS, J.M.; CARVALHO, A.C. Preliminary spatial and temporal analysis of citrus variegated chlorosis (CVC) in São Paulo, Brazil. In: INTERNATIONAL ORGANIZATION OF CITRUS VIROLOGISTS CONFERENCE, 12., Riverside, 1993. Proceedings. Riverside: IOCV, 1993. p.327335 .

GOUGH, C.L.; DOW, J.M.; BARBER, C.E.; DANIELS, M.J. Cloning of two endoglucanases genes of Xanthomonas campestris pv. campestris: analysis of the role of the major endoglucanase in pathogenicity. Molecular Plant Microbe Interactions, v.1, p.275-281, 1988. 
GOUGH, C.L.; DOW, J.M.; KEEN, J.; HENRISSAT, B.; DANIELS, M.J. Nucleotide sequence of the engXCA gene encoding the major endoglucanase of Xanthomonas campestris pv. campestris. Gene, v.89, n.1, p.53-59, 1990.

GUILHABERT, M.R.; HOFFMAN, L.M.; MILLS, D.A.; KIRKPATRICK, B.C. Transposon mutagenesis of Xylella fastidiosa by electroporation of Tn5 synaptic complexes. Molecular Plant Microbe Interactions, v.14, n.6, p.701-706, 2001.

GUISEPPI, A.; AYMERIC, J.L.; CAMI, B.; BARRAS, F.; CREUZET, N. Sequence analysis of the cellulase-encoding celY gene of Erwinia chrysanthemi: a possible cause of interspecies gene transfer. Gene, v.106, n.1, p.109-114, 1991.

GUISEPPI, A.; CAMI, B.; AYMERIC, J.L.; BALL, G.; CREUZET, N. Homology between endoglucanase $\mathrm{Z}$ of Erwinia chrysanthemi and endoglucanases of Bacillus subtilis and alkalophilic Bacillus. Molecular Microbiology, v.2, n.1, p.159-164, 1988.

HANAHAN, D Transformation of Escherichia coli with plasmids. Journal of Molecular Biology, v.166, n.4, p.557-580, 1983.

HE, C.X.; LI, W.B.; AYRES, A.J.; HARTUNG, J.H.; MIRANDA, V.S.; TEIXEIRA, D.C. Distribution of Xylella fastidiosa in citrus rootstocks and transmission of citrus variegated chlorosis between sweet orange plants through natural root grafts. Plant Disease, v.84, n.6, p.622-626, 2000.

HEILBRONN, J.; JOHNSTON, D.J.; DUNBAR, B.; LYON, G.D. Purification of a metalloprotease produced by Erwinia carotovora subsp. carotovora and the degradation of potato lectin in vitro. Physiological and Molecular Plant Pathology, v.47, n.5, p.285-292, 1995.

HELDT, H.-W.; HELDT, F. Plant Biochemistry \& Molecular Biology. 1.ed. Oxford: Oxford University Press, 1997. 522p. 
HENRISSAT, B. A classification of glycosyl hydrolases based on amino-acid sequence similarities. Biochemical Journal, v.280, part 2, p.309-316, 1991.

HENRISSAT, B.; BAIROCH, A. New families in the classification of glycosyl hydrolases based on amino-acid sequence similarities. Biochemical Journal, v.293, part 3, p.781788, 1993.

HENRISSAT, B.; CLAEYSSENS, M.; TOMME, P.; LEMESLE, L.; MORNON, J.P. Cellulase families revealed by hydrophobic cluster analysis. Gene, v.81, n.1, p.83-95, 1989.

HENRISSAT, B.; DRIGUEZ, H.; VIET, C.; SCHÜLEIN, M. Synergism of cellulases from Trichoderma reesei in the degradation of cellulose. Bio/Technology, v.3, p.722726, 1985.

HOLT, J.G. Genus Xylella. In: Bergey's manual of determinative bacteriology. 9.ed. Baltimore: Williams \& Wilkins, 1994. 787p.

HOPKINS, D.L. Physiological and pathological characteristics of virulent and avirulent strains of the bacterium that causes Pierce's disease of grapevine. Phytopathology, v.75, n.6, p.713-717, 1985.

HOPKINS, D.L. Xylella fastidiosa: xylem-limited bacterial pathogen of plants. Annual Review of Phytopathology, v.27, p.271-290, 1989.

HOPKINS, D.L.; ADLERZ, W.C. Natural hosts of Xylella fastidiosa in Florida. Plant Disease, v.72, n.5, p.429-431, 1988.

HOPKINS, D.L.; THOMPSON, C.M. Seasonal concentration of the Pierce's diesease bacterium in 'Carlos' and 'Welder' muscadine grapes compared with 'Schuyler' bunch grape. HortScience, v.19, n.3, p.419-420, 1984.

HOUGH, D.W.; DANSON, M.J. Extremozymes. Current Opinion in Chemical Biology, v.3, n.1, p.39-46, 1999. 
HUGOUVIEUX-COTTE-PATTAT, N.; CONDEMINE， G.; NASSER, W.; REVERCHON, S. Regulation of pectinolysis in Erwinia chrysanthemi. Annual Review of Microbiology, v.50, p.213-57, 1996.

INSTITUTO BRASILEIRO DE GEOGRAFIA E ESTATÍSTICA (IBGE). Banco de dados agregados: sistema IBGE de recuperação automática - SIDRA. http://www.sidra.ibge.gov.br/bda (07 jul. 2002)

ISAAC, S. Fungal-plant interactions. Londres: Chapman \& Hall, 1992. 418p.

JAHR, H.; BAHRO, R.; BURGER, A.; AHLEMEYER, J.; EICHENLAUB, R. Interactions between Clavibacter michiganensis and its host plants. Environmental Microbiology, v.1, n.2, p.113-118, 1999.

JAHR, H.; DREIER, J.; MELETZUS, D.; BAHRO, R.; EICHENLAUB, R The endo- $\beta$ 1,4-glucanase CelA of Clavibacter michiganensis subsp. michiganensis is a pathogenicity determinant required for induction of bacterial wilt of tomato. Molecular Plant Microbe Interactions, v.13, n.7, p.703-714, 2000.

KATAEVA, I.; LI, X.-L.; CHEN, H.; CHOI, S.-K.; LJUNGDAHL, L.G. Cloning and sequence analysis of a new cellulase gene encoding CelK, a major cellulosome component of Clostridium thermocellum: evidence for gene duplication and recombination. Journal of Bacteriology, v.181, n.17, p.5288-5295, 1999.

KATZEN, F.; FERREIRO, D.U.; ODDO, C.G.; IELMINI, M.V.; BECKER, A.; PHLER, A.; IELPI, L. Xanthomonas campestris pv. campestris gum mutants: effects on xantham biosynthesis and plant virulence. Journal of Bacteriology, v.180, n.7, p.1607-1617, 1998.

KEEN, N.T.; BOYD, C.; HENRISSAT, B. Cloning and characterization of a xylanase gene from corn strains of Erwinia chrysanthemi. Molecular Plant Microbe Interaction, v.9, n.7, p.651-657, 1996. 
KILIKIAN, B.V.; SUÁREZ, I.D.; LIRIA, C.W.; GOMBERT, A.K. Process strategies to improve heterologous protein production in Escherichia coli under lactose or IPTG induction. Process Biochemistry, v.35, n.9, p.1019-1025, 2000.

KIM, C.H. Characterization and substrate specificity of an endo- $\beta-1,4-D-$ glucanase I (Avicelase I) from an extracellular multienzyme complex of Bacillus circulans. Applied and Environmental Microbiology, v.61, n.3, p.959-965, 1995.

KITAJIMA, E.W.; COLETTA FILHO, H.D.; MACHADO, M.A.; NOVAES, Q.S. Escaldadura das folhas em Hibiscus schizopetalus associada à infecção por Xylella fastidiosa em Brasília, DF. Fitopatologia Brasileira, v.25, p.323, 2000. Suplemento.

KITAJIMA, E.W.; MOHAN, S.K.; TSUNETA, M.; BLEICHER, J.; FRENCH, W.; LEITE JR, R.P. Ocorrência de escaldadura das folhas da ameixeira nos estados do Paraná e Santa Catarina. Fitopatologia Brasileira, v.6, p.285-292, 1981.

KNOWLES, J.; LEHTOVARAARA, P.; TEERI, T. Cellulase families and their genes. Trends in Biotechnology, v.5, p.255-261, 1987.

KONO, H.; WAELCHLI, M.R.; FUJIWARA, M.; ERATA, T.; TAKAI, M. Transglycosylation of cellobiose by partially purified Trichoderma viride cellulase. Carbohydrate Research, v.319, n.1-4, p.29-37, 1999.

KRÜGNER, R.; LOPES, M.T.V. de C.; SANTOS, J.S.; BERETTA, M.J.G.; LOPES, J.R.S. Transmission efficiency of Xylella fastidiosa by sharpshooters and identification of two new vector species. In: CONFERENCE OF THE INTERNATIONAL ORGANIZATION OF CITRUS VIROLOGISTS, 14., Campinas, 1998. Program \& Abstracts. Cordeirópolis: IAC, 1998. p.81.

LAEMMLI, U.K. Cleavage of structural proteins during the assembly of the head of bacteriophage T4. Nature, v.227, n.259, p.680-685, 1970. 
LAINE, M.J.; HAAPALAINEN, M.; WAHLROSS, T.; KANKARE, K.; NISSINEN, R.; KASSUWI, S.; METZLER, M.C. The cellulase encoded by the native plasmid of Clavibacter michiganensis ssp. sepedonicus plays a role in virulence and contains an expansin-like domain. Physiological and Molecular Plant Pathology, v.57, n.5, p.221-233, 2000.

LAMBAIS, M.R.; GOLDMAN, M.H.S.; CAMARGO, L.E.A.; GOLDMAN, G.H. A genomic approach to the understanding of Xylella fastidiosa pathogenicity. Current Opinion in Microbiology, v.3, n.5, p.459-462, 2000.

LARANJEIRA, F.F. Dinâmica espacial e temporal da clorose variegada dos citros. Piracicaba, 1997. 144p. Dissertação (Mestrado) - Escola Superior de Agricultura “Luiz de Queiroz”, Universidade de São Paulo.

LARANJEIRA, F.F. Epidemiologia da clorose variegada dos citros no estado de São Paulo. Piracicaba, 2002. 158p. Tese (Doutorado) - Escola Superior de Agricultura “Luiz de Queiroz”, Universidade de São Paulo.

LARANJEIRA, F.F.; POMPEU JÚNIOR, J.; HARAKAVA, R.; FIGUEIREDO, J.O.; CARVALHO, S.A.; COLETTA FILHO, H.D. Cultivares e espécies cítricas hospedeiras de Xylella fastidiosa em condições de campo. Fitopatologia Brasileira, v.23, n.2, p.147-154, 1998.

LEE, R.F.; BERRETA, M.J.G.; DERRICK, K. Clorose variegada dos citros: uma nova e destrutiva doença dos citros no Brasil. Laranja, v.12, n.2, p.345-356, 1991.

LEE, R.F.; BERRETTA, M.J.G.; HARTUNG, J.H.; HOOKER, M.E.; DERRICHK, K.S. Citrus variegated chlorosis: confirmation of a Xylella fastidiosa as the causal agent. Summa Phytopathologica, v.19, n.2, p.123-125, 1993.

LEE, R.F.; RAJU, B.C.; NYLAND, G.; GOHEEN, A.C. Phytotoxin(s) produced in culture by the Pierce's disease bacterium. Phytopathology, v.72, n.7, p.886-888, 1982. 
LEITE, B.; ISHIDA, M.L.; ALVES, E.; CARRER, H.; PASCHOLATI, S.F.; KITAJIMA, E.W. Genomics and X-ray microanalysis indicates that $\mathrm{Ca}^{2+}$ and thiols mediate the aggregation and adhesion of $X$. fastidiosa. Brazilian Journal of Medical and Biological Research, v.35, n.6, p.645-650, 2002.

LEITE, B.; PASCHOLATI, S.F.; KITAJIMA, E.W.; ISHIDA, M.L. Mecanismos de adesão de bactérias e fungos às plantas hospedeiras. Revisão Anual de Patologia de Plantas, v.9, p.119-157, 2001.

LEITE, R.M.V.B.C.; LEITE JR, R.P.; CEREZINE, P.C. Hospedeiros alternativos para Xylella fastidiosa entre plantas invasoras de pomares de ameixeira com escaldadura da folha. Fitopatologia Brasileira, v.22, n.1, p.54-57, 1997.

LEU, L.S.; SU, C.C. Isolation, cultivation and pathogenicity of Xylella fastidiosa, the causal bacterium of pear leaf scorch disease in Taiwan. Plant Disease, v.77, n.6, p.642-646, 1993.

LEVER, M. A new reaction for colorimetric determination of carbohydrates. Analytical Biochemistry, v.47, n.1, p.273-279, 1972.

LI, W.B.; PRIA JÚNIOR, W.D.; TEIXEIRA, D.C.; MIRANDA, V.S.; AYRES, A.J.; FRANCO, C.F.; COSTA, M.G.; HE, C.-X.; COSTA, P.I.; HARTUNG, J.S. Coffee leaf scorch caused by a strain of Xylella fastidiosa from citrus. Plant Disease, v.85, n.5, p.501-505, 2001.

LI, W.B.; ZREIK, L.; FERNANDES, N.G.; MIRANDA,V.S.; TEIXEIRA, D.C.; AYRES, A.J.; GARNIER, M.; BOVÉ, J.M. A triply cloned strain of Xylella fastidiosa multiplies and induces symptoms of citrus variegated chlorosis in sweet orange. Current Microbiology, v.39, n.2, p.106-108, 1999.

LIAO, C.-H.; GAFFNEY, T.D.; BRADLEY, S.P.; WONG, L.-J.C. Cloning of a pectate lyase gene from Xanthomonas campestris pv. malvacearum and comparison of its sequence relationship with pel genes of soft-rot Erwinia and Pseudomonas. Molecular Plant Microbe Interaction, v.9, n.1, p.14-21, 1996. 
LIAO, C.-H.; HUNG, H.-Y.; CHATTERJEE, A.K. An extracellular pectate lyase is the pathogenicity factor of the soft-rotting bacterium Pseudomonas viridiflava. Molecular Plant Microbe Interaction, v.1, p.199-206, 1988.

LIAO, C.-H.; MCCALLUS, D.E.; FETT, W.F. Molecular characterization of two gene loci required for production of the key pathogenicity factor pectate lyase in Pseudomonas viridiflava. Molecular Plant Microbe Interaction, v.7, n.3, p.391-400, 1994.

LINDER, M.; TEERI, T.T. The roles and function of cellulose-binding domains. Journal of Microbiology, v.57, p.15-28, 1997.

LOPES, J.R.S. Estudos com vetores de Xylella fastidiosa e implicações no manejo da clorose variegada dos citros. Laranja, v.20, n.2, p.329-344, 1996.

LOPES, S.A.; RIBEIRO, D.M.; ROBERTO, P.G.; FRANÇA, S.C.; SANTOS, J.M. Nicotiniana tabacum as an experimental host for the study of plant-Xylella fastidiosa interactions. Plant Disease, v.84, n.8, p.827-830, 2000.

MACHADO, M.A.; SILVÉRIO, J.L.; BAPTISTA, C.R.; CRISTOFANI, M.; SOBRINHO, J.T. Avaliação de transmissão e seleção de variedades à clorose variegada dos citros (CVC). Laranja, v.13, n.2, p.515-531, 1992.

MACHADO, M.A.; TARGON, M.L.P.N.; BERETTA, M.J.G.; LARANJEIRA, F.F.; CARVALHO, S.A. Detecção de Xylella fastidiosa em espécies e variedades de citros sobre-enxertadas em laranja pera com clorose variegada dos citros (CVC). Fitopatologia Brasileira, v.22, n.1, p.30-33, 1987.

MÄE, A.; HEIKINHEIMO, R.; PALVA, E.T. Structure and regulation of Erwinia carotovora subsp. carotovora SCC3193 Cellulase gene celV1 and the role of cellulase in phytopathogenicity. Molecular and General Genetics, v.247, n.1, p.17-26, 1995. 
MALAVOLTA, E.; MALAVOLTA, M.L.; CABRAL, C.P.; PRATES, H.S.; VITTI, GC. Nova anomalia dos citros: estudos preliminares. Laranja, v.11, n.1, p.15-38, 1990.

MARITS, R.; KOIV, V.; LAASIK, E.; MAE, A Isolation of an extracellular protease gene of Erwinia carotovora subsp carotovora strain SCC3193 by transposon mutagenesis and the role of protease in phytopathogenicity. Microbiology, v.145, part 8, p.19591966, 1999.

MARQUES, L.L.R.; CERI, H.; MANFIO, G.P.; REID, D.M.; OLSON, M.E. Characterization of biofilm formation by Xylella fastidiosa in vitro. Plant Disease, v.86, n.6, p.633-638, 2002.

MEINKE, A.; GILKES, N.R.; KILBURN, D.G.; MILLER, R.C.Jr.; WARREN, R.A.J. Cellulose-binding polypeptides from Cellulomonas fimi: endoglucanase $\mathrm{E}(\mathrm{CenD})$, a family A $\beta$-1,4-glucanase. Journal of Bacteriology, v.175, n.7, p.1910-1918, 1993.

MELETZUS, D.; BERMPOHL, A.; DREIER, J.; EICHENLAUB, R. Evidence for plasmid-encoded virulence factors in the phytopathogenic bacterium Clavibacter michiganensis ssp. michiganensis NCPPB382. Journal of Bacteriology, v.175, n.7, p.2131-2136, 1993.

MINSAVAGE, G.V.; THOMPSON, C.M.; HOPKINS, D.L.; LEITE, R.M.V.B.C.; STALL, R.E. Development of a polymerase chain reaction protocol for detection of Xylella fastidiosa in plant tissue. Phytopathology, v.84, n.5, p.456-461, 1994.

MIRMETICH, S.M.; LOWE, S.K.; MOLLER, W.J.; NYLAND, G. Etiology of almond leaf scorch disease and transmission of the causal agent. Phytopathology, v.66, n.1, p.17-24, 1976. 
MIZUBUTI, E.S.G.; MATSUOKA, K.; PARIZZI, P. Associação de bactéria do tipo Xylella em laranjeiras com sintomas de clorose variegada na região da zona da mata de Minas Gerais. Fitopatologia Brasileira, v.19, p.241-244, 1994.

MOLLENHAUER, H.H.; HOPKINS, D.L. Xylem morphology of Pierce's disease infected grapevines with different levels of tolerance. Physiological Plant Pathology, v.9, p.95-100, 1976.

MONTEIRO, P.B.; RENAUDIN, J.; JAGOUEIX-EVELILLARD, S.; AYERS， A.J.; GARNIER, M.; BOVE, J.M. Catharanthus roseus, an experimental host plant for the citrus strain of Xylella fastidiosa. Plant Disease, v.85, n.3, p.246-251, 2001a.

MONTEIRO, P.B.; TEIXEIRA, D.C.; PALMA, R.R.; GARNIER, M.; BOVE, J.M.; RENAUDIN, J. Stable transformation of the Xylella fastidiosa citrus variegated chlorosis strain with oriC plasmids. Applied and Environmental Microbiology, v.67, n.5, p.2263-2269, 2001b.

MONTEIRO, R.A.; SOUZA, E.M.; FUNAYAMA, S.; YATES, M.G.; PEDROSA, F.O.; CHUBATSU, L.S. Expression and functional analysis of an $\mathrm{N}$-truncated NifA protein of Herbaspirillum seropedicae. FEBS Letters, v.447, n.2-3, p.283-286, 1999.

MULLIS, K.B.; FALOONA, F.A. Specific synthesis of DNA in vitro via a polymerase catalyzed chain reaction. Methods in Enzymology, v.155, p.335-350, 1990.

NANKAI, H.; HASHIMOTO, W.; MIKI, H.; KAWAI, S.; MURATA, K. Microbial system for polysaccharide depolymerization: enzymatic route for xanthan depolymerization by Bacillus sp. strain GL1. Applied and Environmental Microbiology, v.65, n.6, p.2520-2526, 1992.

NAVAS, J.; BEGUIN, P. Site-directed mutagenesis of conserved residues of Clostridium thermocellum endoglucanase CelC. Biochemistry and Biophysics Research Communications, v.189, n.2, p.807-812, 1992. 
NIELSEN, H.; ENGELBRECHT, J.; BRUNAK, S.; VON HEIJNE, G. Identification of prokaryotic and eukaryotic signal peptides and prediction of their cleavage sites. Protein Engineering, v.10, p.1-6, 1997.

NILSSON, J.; STAHL, S.; LUNDEBERG, J.; UHLÉN, M.; NYGREN, P.-A. Affinity fusion strategies for detection, purification, and immobilization of recombinant proteins. Protein Expression and Purification, v.11, n.1, p.1-16, 1997.

PARADELA FILHO, O.; SUGIMORI, M.H.; RIBEIRO, I.J.A.; MACHADO, M.A.; LARANJEIRA, F.F.; GARCIA JÚNIOR, A.; BERETTA, M.J.G. Primeira constatação em cafeeiro no Brasil, da Xylella fastidiosa causadora da clorose variegada dos citros. Laranja, v.16, n.2, p.135-136, 1995.

PARK, J.-S.; SHIN, H.-S.; DOI, R.H. Fusion proteins containing cellulose-binding domains. Methods in Enzymology, v.326, p.418-429, 2000.

PARK, Y.W.; LIM, S.T.; YUN, HD. Cloning and sequencing of the celA gene encoding CMCase of Erwinia carotovora subsp. carotovora LY34. Molecules and Cells, v.8, n.1, p.27-35, 1998.

PASCHOLATI, S.F.; ALVES, E.; MARUCCI, R.C.; LOPES, J.R.S.; LEITE, B. Vasos do xilema colonizados por X.f. em ameixeira, cafeeiro e citros e a sintomatologia. Fitopatologia Brasileira, v.27, p.68, 2002. Suplemento.

PEGDEN, R.S.; LARSON, M.A.; GRANT, R.J.; MORRISON, M. Adherence of the grampositive bacterium Ruminococcus albus to cellulose and identification of a novel form of cellulose-binding protein wich belongs to the Pil family of proteins. Journal of Bacteriology, v.180, n.22, p.2921-2927, 1998.

PEREIRA, E.F. Estudo de fatores sazonais relacionados à transmissão de Xylella fastidiosa em pomares de citros. Piracicaba, 2000. 82p. Dissertação (Mestrado) - Escola Superior de Agricultura "Luiz de Queiroz", Universidade de São Paulo. 
PETTERSSON, B.; ERIKSSON, K-E.,L. A standardized spectrophotometric assay of endoglycanase activities using dyed, amorphous polysaccharides. Analytical Biochemistry, v.285, p.220-224, 2000.

PIERSON III, L.S.; WOOD, D.W.; PIERSON, E.A. Homoserine lactone-mediated gene regulation in plant-associated bacteria. Annual Review of Phytophatology, v.36, p.207-225, 1998.

POOLE, D.M.; HAZLEWOOD, G.P.; HUSKISSON, N.S.; VIRDEN, R.; GILBERT, H.J. The role of conserved tryptophan residues in the interactions of a bacterial cellulose binding domain with its ligand. FEMS Microbiology Letters, v.106, n.1, p.77-84, 1993.

POOLER, M.R.; HARTUNG, J.S. Specific detection and identification of Xylella fastidiosa strains causing citrus variegated chlorosis. Current Microbiology, v.31, n.6, p.377-381, 1995 .

PRADE, R.A.; ZHANG, D-F.; AYOUBI, P.; MORT, A.J. Pectins, pectinases and plantmicrobe nteractions. Biotechnology and Genetic Engineering Reviews, v.16, p.361$391,1999$.

PURCELL, A.H.; FINLAY, A.H. Evidence for noncirculative transmisson of Pierce's disease bacterium by sharpshooter leafhoppers. Phytopathology, v.69, n.4, p.393-395, 1979.

PURCELL, A.H.; HOPKINS, D.L. Fastidious xylem-limited bacterial plant pathogens. Annual Review of Phytopathology, v.34, p.131-151, 1996.

PY, B.; BORTOLI-GERMAN, I.; HAIECH, J.; CHIPPAUX, M.; BARRAS, F. Cellulase EGZ of Erwinia chrysanthemi: structural organization and importance of His98 and Glu133 residues for catalysis. Protein Engineering, v.4, n.3, p.325-333, 1991. 
QIN, X.; HARTUNG, J.S. Construction of a shuttle vector and transformation of Xylella fastidiosa with plasmid DNA. Current Microbiology, v.43, n.3, p.158-162, 2001.

QUEIROZ-VOLTAN, R.B.; PARADELA FILHO, O. Caracterização de estruturas anatômicas de citros infectados com Xylella fastidiosa. Laranja, v.20, n.1, p.55-76, 1999.

RAJU, B.C.; WELLS, J.M.; NYLAND, G.; BRLANSKY, R.H.; LOWE, S.K. Plum leaf scald: isolation, culture and pathogenicity of the causal agent. Phytopathology, v.72, n.11, p.1460-1466, 1982.

RAVEN, P.H.; EVERT, R.F.; CURTIS, H. Biologia vegetal. 2.ed. Rio de Janeiro: Guanabara Dois, 1976. 724p.

RAVEN, P.H.; EVERT, R.F.; EICHHORN, S.E. Biologia vegetal. 6.ed. Rio de Janeiro: Guanabara Dois, 2001. 906p.

ROBERTO, S.R.; COUTINHO, A.; DE LIMA, J.E.O.; MIRANDA, V.S.; CARLOS, E.F. Transmissão de Xylella fastidiosa pela cigarrinhas Dilobopterus costalimai, Acrogonia terminalis e Oncometopia fascialis em citros. Fitopatologia Brasileira, v.21, n.4, p.517-518, 1996.

ROBERTS, D.P.; DENNY, T.P.; SCHELL, M.A. Cloning of the Egl gene of Pseudomonas solanacearum and analysis of its role in pathogenicity. Journal of Bacteriology, v.170, n.4, p.1445-1451, 1988.

ROSSETTI, V.; CARVALHO, M.L.V.; CHAGAS, C.M. Ensaios de transmissão de clorose variegada dos citros (CVC) em campo. Fitopatologia Brasileira, v.20, p.67, 1995. Suplemento.

ROSSETTI, V.; DE NEGRI, D. Clorose variegada dos citros: revisão. Laranja, v.11, n.1, p.1-14, 1990. 
ROSSETTI, V.; GARNIER, M.; BOVÉ, J.M.; BERETTA, M.J.G.; TEIXEIRA, A.R.R.; QUAGGIO, J.A.; DE NEGRI, J.D. Présence de bactéries dans le xylème d'oranges atteints de chlorose variégée, une nouvelle maladie des agrumes au Brésil. Comptus Rendus de Academie Sciences Paris, v.310, p.345-349, 1990.

SAARILAHTI, H.T.; HENRISSAT, B.; PALVA, E.T. CelS: a novel endoglucanase identified from Erwinia carotovora subsp. carotovora. Gene, v.90, n.1, p.9-14, 1990.

SALANOUBAT, M.; GENIN, S.; ARTIGUENAVE, F. et al. Genome sequence of the plant pathogen Ralstonia solanacearum. Nature, v.415, n.6871, p.497-502, 2002.

SALMOND, G.P.C. Secretion of extracellular virulence factors by plant pathogenic bacteria. Annual Review of Phytopathology, v.32, p.181-200, 1994.

SAMBROCK, J.; FRITISCH, E.F.; MANIATIS, J. Molecular cloning. 2.ed. New York: Cold Spring Harbor Laboratory Press, 1989. 3v.

SANDERLIN, R.S.; HEYDERICH-ALGER, H.I. Evidence that Xylella fastidiosa can cause leaf scorch disease of pecan. Plant Disease, v.84, n.12, p.1282-1286, 2000.

SCARPARI, L.M. Modulação da expressão de genes de patogenicidade putativos em Xylella fastidiosa sob condições de baixa e alta densidade celular. Piracicaba, 2001. 85p. Dissertação (Mestrado) - Escola Superior de Agricultura "Luiz de Queiroz", Universidade de São Paulo.

SCHARF, S.J.; HORN, G.T.; ERLICH, H.A. Direct cloning and sequence analysis of enzymatically amplified genomic sequences. Science, v.233, n.4768, p.1076-1078, 1986.

SCHÜLEIN, M. Protein engineering of cellulases. Biochimica et Biophysica Acta, v.1543, n.2, p.239-252, 2000.

SCOPES, R.K. Protein purification: principles and practice. New York: Springer Verlag, 1982. 282p. 
SEGNANA, L.R.; VILLALBA, N.; MEZZAROMA, A.C.; QARRA, D.; SANTOS, J.S.; MATIENZO, P.A.; BERETTA, M.J.G. First report of Xylella fastidiosa causing citrus variegated chlorosis (CVC) in Paraguay. Fitopatologia Brasileira, v.23, p.216, 1998. Suplemento.

SHEFFIELD, V.C.; COX, D.R.; LERMAN, L.S.; MYERS, R.M. Attachment of a 40-base pair $\mathrm{G}+\mathrm{C}$ rich sequence (GC clamp) to genomic DNA fragments by the polymerase chain reaction results in improved detection of single base changes. Proceedings of the National Academy os Sciences of the USA, v.86, n.1, p.232-236, 1989.

SHEN, H.; GILKES, N.R.; KILBURN, D.G.; MILLER, R.C.Jr.; WARREN, R.A.J. Cellobiohydrolase B, a second exo-cellobiohydrolase from the cellulolytic bacterium Cellulomonas fimi. Biochemical Journal, v.311, part 1, p.67-74, 1995.

SILVA, A.C.da; FERRO, J.A.; REINACH, R.C. et al. Comparison of the genomes of two Xanthomonas pathogens with differing host specificities. Nature, v.417, n.6887, p.417-463, 2002.

SILVA, A.C.R. da; FERRO, J.A.; REINACH, F.C. et al. Comparison of the genomes of two Xanthomonas pathogens with differing host specificities. Nature, v.417, n.6887, p.459-463, 2002.

SILVA, F.R.da; VETORE, A.L.; EDSON, L.K.; LEITE, A.; ARRUDA, P. Fastidian gum: the Xylella fastidiosa exopolysaccharide possibly involved in bacterial pathogenicity. FEMS Microbiology Letters, v.203, n.2, p.165-171, 2001.

SIMPSON, A.J.G.; REINACH, F.C., ARRUDA, P. et al. The genome sequence of the plant pathogen Xylella fastidiosa. Nature, v.406, n.6792, p.151-159, 2000.

SINNOTT, M.L. Catalytic mechanisms of enzymatic glycosyl transfer. Chemical Reviews, v.90, n.7, p.1171-1202, 1990.

STRYER, L. Biochemistry. 4.ed. Guanabara Koogan: Rio de Janeiro, 1996. 881p. 
STUDIER, F.W. Use of bacteriophage T7 lysozyme to improve an inducible T7 expression system. Journal of Molecular Biology, v.219, n.1, p.37-44. 1991.

STUDIER, F.W.; MOFFATT, B.A. Use of bacteriophage-T7 RNA-polymerase to direct selective high-level expression of cloned genes. Journal of Molecular Biology, v.189, n.1, p.113-130, 1986.

SUGIMORI, M.H.; PARADELA FILHO, O.; RIBEIRO, I.J.A.; LARANJEIRA, F.F.; GARCIA JÚNIOR., A.; MARTINS, A.L.M. Estudo de transmissão do agente da CVC por semente. Summa Phytopathologica, v.22, n.1, p.58, 1995. Suplemento.

TANG, J.L.; GOUGH, C.L.; BARBER, C.E.; DOW, J.M.; DANIELS, M.J. Molecular cloning of protease gene(s) from Xanthomonas campestris pv. campestris: expression in Escherichia coli and role in pathogenicity. Molecular and General Genetics, v.210, n.3, p.443-448, 1987.

TATUSOVA, T.A.; MADDEN, T.L. Blast 2 sequences: a new tool for comparing protein and nucleotide sequences. FEMS Microbiology Letters, v.174, n.2, p.247-250, 1999.

TEAKLE, D.S.; SMITH, P.M.; STEINDL, D.R.L. Ratoon stunting disease of sugarcane: possible correlation of resistance with vascular anatomy. Phytopathology, v.65, n.2, p.138-141, 1975.

TEATHER, R.M.; WOOD, P.J. Use of congo red polysaccharide interactions in enumeration and characterization of cellulolytic bacteria from the bovine rumen. Applied and Environmental Microbiology, v.43, n.4, p.777-780, 1982.

TOMME, P.; WARREN, R.A.J.; MILLER, R.C.; KILBURN, D.G.; GILKES, N.R. Cellulose-binding domains: classification and properties. ACS Symposium Series, v.618, p.143-163, 1995.

TRAVENSOLO, R.F.; LEITE JR, R.P. Hospedeiros alternativos de Xylella fastidiosa entre plantas invasoras de pomares de citros com clorose variegada. Fitopatologia Brasileira, v.21, p.336, 1996. Suplemento. 
TUBELIS, A.; BARROS, J.C.; LEITE, R.M.V.B. Difusão da clorose variegada dos citros em pomares comerciais de laranja doce no Brasil. Laranja, v.14, n.1, p.239-254, 1993.

VROEMEN, S.; HELDENS, J.; BOYD, C.; HENRISSAT, B.; KEEN, N.T. Cloning and characterization of the $\operatorname{bgxA}$ gene from Erwinia chrysanthemi D1 wich encodes a $\beta$ glucosidase/xylosidase enzyme. Molecular and General Genetics, v.246, n.4, p.465477, 1995.

WALL, D.; KAISER, D. Type IV pili and cell motility. Molecular Microbiology, v.32, n.1, p.1-10, 1999.

WANG, Q.; TULL, D.; MEINKE, A.; GILKES, N.R.; WARREN, R.A. Jr.; AEBERSOLD, R.; WITHERS, S.G. Glu ${ }^{280}$ is the nucleophile in the active site of Clostridium thermocelum CelC, a family A endo- $\beta-1,4$-glucanase. Journal of Biological Chemistry, v.268, n.19, p.14069-14102, 1993.

WEELS, J.M.; RAJU, B.C.; HUNG, HY.; WEINSBERG, W.G.; MANDELCO-PAUL, L.; BRENNER, D.J. Xylella fastidiosa gen. nov. sp. nov.: Gram-negative, xylem-limited fastidious plant bacteria related to Xanthomonas spp. International Journal of Systematic Bacteriology, v.37, n.2, p.136-143, 1987.

WELLS, J.M.; RAJU, B.C.; NYLAND, G.; LOWE, S.K. Medium for isolation and growth of bacteria associated wich plum leaf scald and phony peach diaseases. Applied and Environmental Microbiology, v.42, n.2, p.357-363, 1981.

WENDLAND, A. Diversidade genética de Xylella fastidiosa em três regiões produtoras de citros (Citrus sinensis) do estado de São Paulo. Piracicaba, 2000. 75p. Dissertação (Mestrado) - Escola Superior de Agricultura "Luiz de Queiroz", Universidade de São Paulo. 
WILLIS, J.W.; ENGWALL, J.K.; LEACH, J.E.; CHATTERJEE, A.K. Extracellular protease of Erwinia carotovora subsp. carotovora: characterization and involvement in soft rot pathogenesis. Phytopathology, v.77, n.12, p.1736, 1987.

WILSON, T.J.G.; BERTRAND, N.; TANG, J.L.; FENG, J.X.; PAN, M.Q.; BARBER, C.E.; DOW, J.M.; DANIELS, M.J. The rpfA gene of Xanthomonas campestris pathovar campestris, which is involved in the regulation of pathogenicity factor production, encodes an aconitase. Molecular Microbiology, v.28, n.5, p.961-970, 1998.

WOOD, P.J.; ERFLE, ID.; TEATHER, R.M. Use of complex formation between congo red and polysaccharide in detection and assay of polysaccharide hydrolases. Methods in Enzymology, v.160, p.59-74, 1988.

WOOD, T.M.; BHAT, K.M. Methods for measuring cellulase activities. Methods in Enzymology, v.160, p.87-112, 1988.

YAMAMOTO, P.T.; ROBERTO, S.R.; PRIA JÚNIOR, W.D.; FELIPPE, M.R.; MIRANDA, V.S.; TEIXEIRA, D.C.; LOPES, J.R.S. Transmissão de Xylella fastidiosa pela cigarrinhas Homalodisca ignorata, Acrogonia virescens e Molomea cincta (Hemiptera: Cicadellidae) em plantas cítricas. Summa Phytopathologica, v.26, n.1, p.128, 2000. Suplemento.

ZHOU, S.; INGRAM, L.O. Synergistic hydrolysis of carboxymethyl cellulose and acidswollen cellulose by two endoglucanases (CelZ and CelY) from Erwinia chrysanthemy. Journal of Bacteriology, v.182, n.20, p.5676-5682, 2000. 
APÊNDICES 


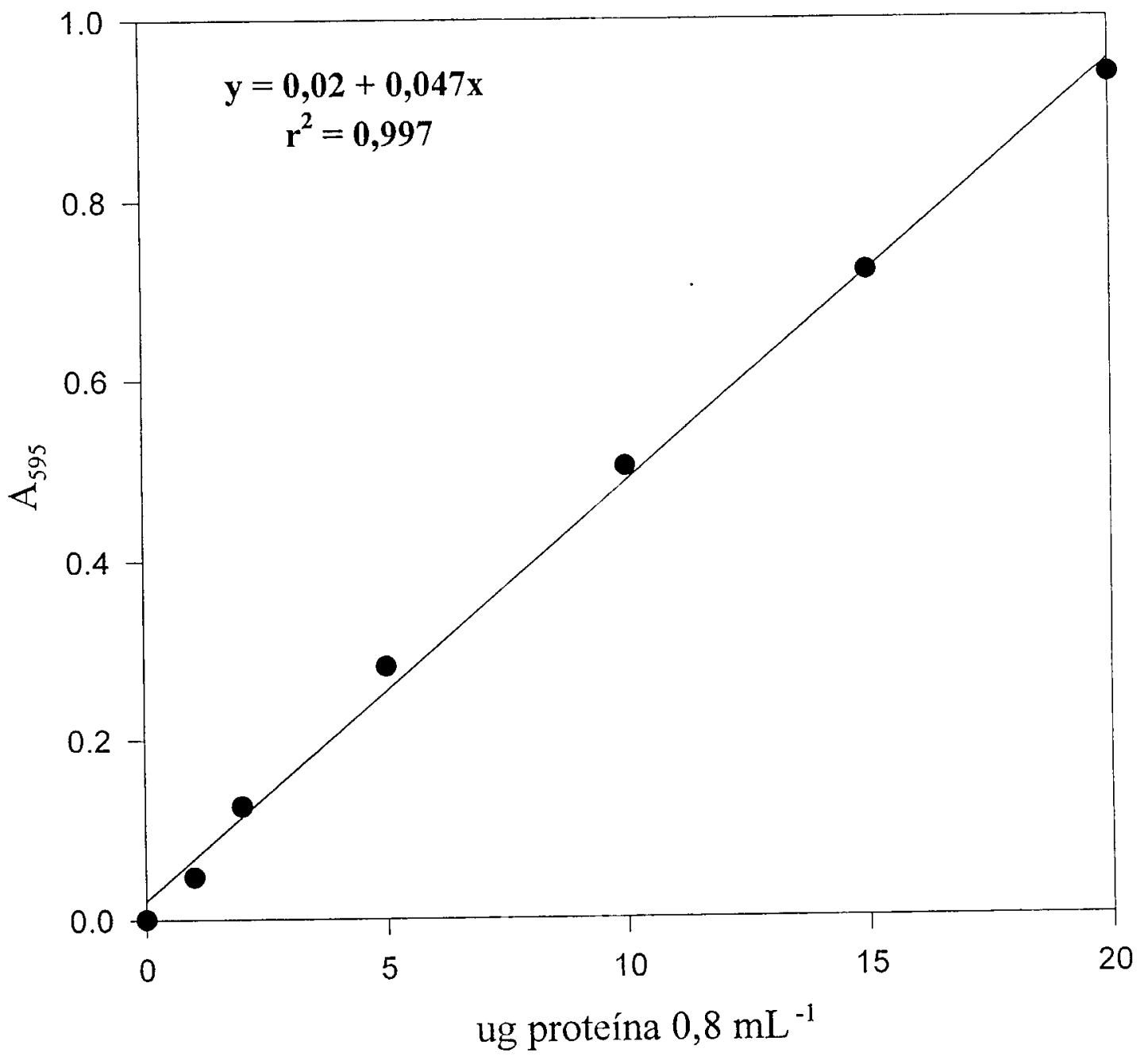

APÊNDICE 1 - Curva padrão para a dosagem de proteínas através do método de Bradford (1976), utilizando reagente concentrado. 


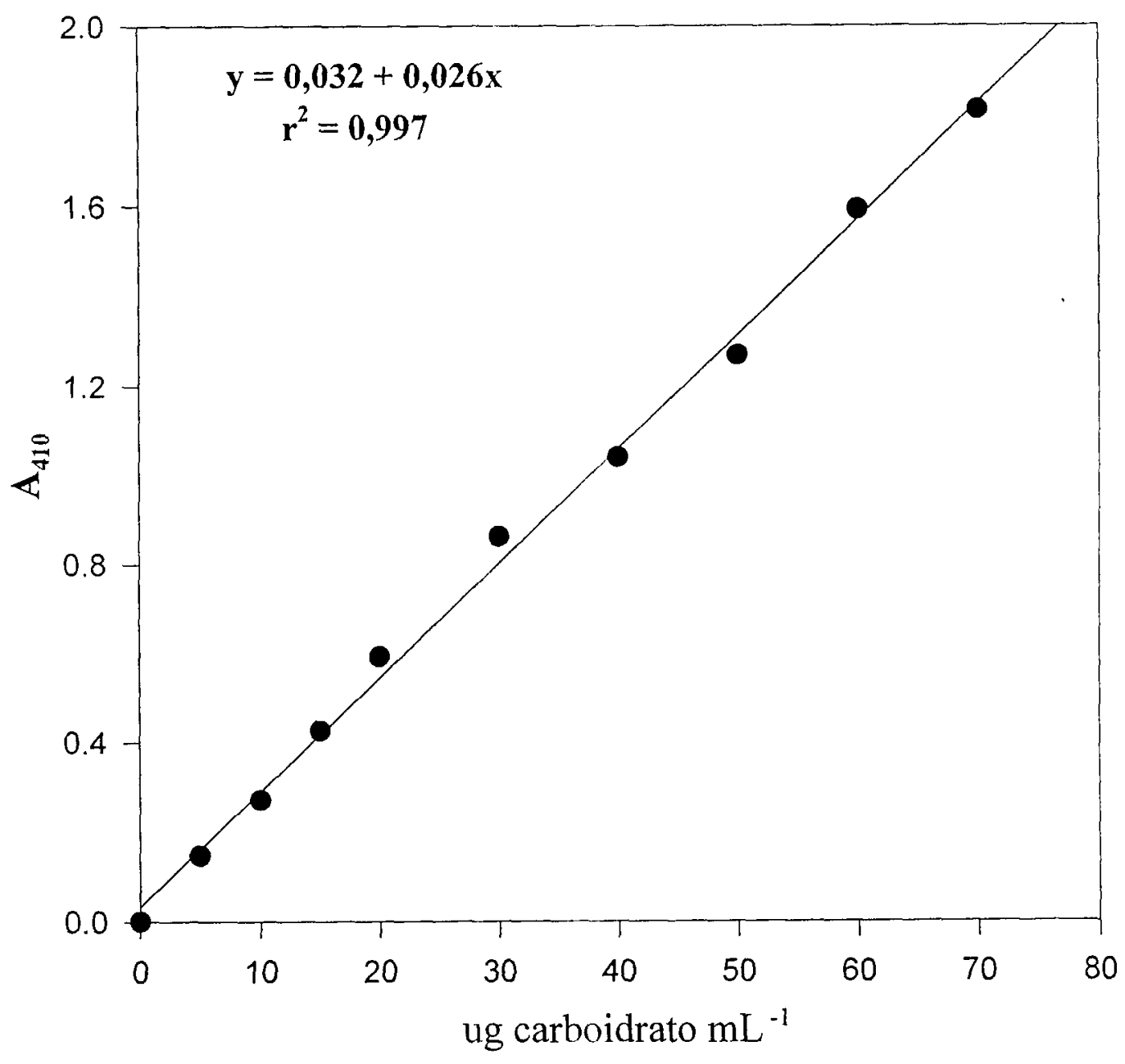

APÊNDICE 2 - Curva padrão para a dosagem de carboidratos redutores através do método de Lever (1972). 
APÊNDICE 3 - Posição dos sete aminoácidos conservados nas hidrolases glicosídicas da família 5, como determinado por Wang et al. (1993), com base na endoglicanase CelC de Clostridium thermocellum e suas posições relativas nas celulases de $X$. fastidiosa.*

\begin{tabular}{|c|c|c|c|c|c|c|c|c|}
\hline \multirow{2}{*}{$\begin{array}{l}\text { Enzima } \\
\text { CelC }\end{array}$} & \multicolumn{7}{|c|}{ Aminoácido conservado ${ }^{1}$} & \multirow[t]{2}{*}{ Bactéria $^{2}$} \\
\hline & $\mathrm{R}^{46}$ & $\mathrm{H}^{90}$ & $\mathrm{~N}^{139}$ & $E^{140}$ & $\mathrm{H}^{198}$ & $\mathrm{Y}^{200}$ & $E^{280}$ & \\
\hline$X f-810$ & $\mathrm{R}^{60}$ & $\mathrm{H}^{112}$ & $\mathrm{~N}^{162}$ & $\mathbf{H}^{163}$ & $S^{264}$ & $D^{266}$ & $\mathrm{E}^{333}$ & X. fastidiosa $9 \mathrm{a} 5 \mathrm{c}$ \\
\hline$X f-818$ & $\mathrm{R}^{82}$ & $\mathrm{H}^{135}$ & $\mathrm{~N}^{180}$ & $\mathrm{E}^{181}$ & $\mathrm{H}^{260}$ & $Y^{262}$ & $\mathrm{E}^{303}$ & X. fastidiosa $9 \mathrm{a} 5 \mathrm{c}$ \\
\hline$X f-2708$ & $\mathrm{R}^{82}$ & $\mathrm{H}^{125}$ & $\mathrm{~N}^{168}$ & $\mathrm{E}^{169}$ & $\mathrm{H}^{240}$ & $Y^{242}$ & $E^{282}$ & X. fastidiosa $9 \mathrm{a} 5 \mathrm{c}$ \\
\hline$X f-810$ & $\mathrm{R}$ & $\mathrm{H}$ & $\mathrm{N}$ & $\mathbf{H}$ & $\mathbf{S}$ & D & $\mathrm{E}$ & X. fastidiosa $\mathrm{PD}^{3}$ \\
\hline$X f-818$ & $\mathrm{R}$ & $\mathrm{H}$ & $\mathrm{N}$ & $\mathrm{E}$ & $\mathrm{H}$ & Y & $\mathrm{E}$ & X. fastidiosa $\mathrm{PD}$ \\
\hline$X f-2708$ & $\mathrm{R}^{83}$ & $\mathrm{H}^{126}$ & $\mathrm{~N}^{169}$ & $\mathrm{E}^{170}$ & $\mathrm{H}$ & $\mathrm{Y}$ & $\mathrm{E}$ & X. fastidiosa PD \\
\hline$X f-810$ & $\mathrm{R}$ & $\mathrm{H}$ & $\mathrm{N}$ & $\mathbf{H}$ & $\mathbf{S}$ & D & $\mathrm{E}$ & X. fastidiosa Ann1 \\
\hline $\mathrm{Xf}-818$ & $\mathrm{R}$ & $\mathrm{H}$ & $\mathrm{N}$ & $\mathrm{E}$ & $\mathrm{H}$ & $\mathrm{Y}$ & $\mathrm{E}$ & X. fastidiosa Ann1 \\
\hline$X f-2708$ & $?$ & $\mathrm{H}$ & $\mathrm{N}$ & $\mathrm{E}$ & $\mathrm{H}$ & $\mathrm{Y}$ & $\mathrm{E}$ & X. fastidiosa Ann1 \\
\hline$X f-810$ & $\mathrm{R}$ & $\mathrm{H}$ & $Y$ & $\mathbf{H}$ & $\mathbf{S}$ & $\mathbf{D}$ & $\mathrm{E}$ & $X$. fastidiosa Dixon \\
\hline$X f-818$ & $\mathrm{R}$ & $\mathrm{H}$ & $\mathrm{N}$ & $\mathrm{E}$ & $\mathrm{H}$ & $\mathrm{Y}$ & $\mathrm{E}$ & $X$. fastidiosa Dixon \\
\hline$X f-2708$ & $\mathrm{R}$ & $\mathrm{H}$ & $\mathrm{N}$ & $\mathrm{E}$ & $\mathrm{H}$ & $\mathrm{Y}$ & $\mathrm{E}$ & $X$. fastidiosa Dixon \\
\hline
\end{tabular}

A posição refere-se àquela ocupada pelo aminoácido na estrutura primária da proteína; aa em negrito são os dissimilares àqueles observados no consenso da família 5. $\mathrm{E}^{140}$ é o catalista ácido base e $\mathrm{E}^{280}$ o nucleófilo sítio ativo (CelC);

2 X. fastidiosa 9a5c - citros (Simpson et al., 2000); X. fastidiosa videira (ONSA/FAPESP); X. fastidiosa Ann1 - espirradeira e X. fastidiosa Dixon amendoeira (Bhattacharyya et al., 2002).

3 Aminoácidos sem posição indicada apresentam a mesma numeração que observada em $X$. fastidiosa $9 \mathrm{a} 5 \mathrm{c}$.

* O número da orf de $X$. fastidiosa 9 a 5 c foi mantida para termos comparativos. $\mathrm{D}=$ ácido aspártico; $\mathrm{E}=$ ácido glutâmico; $\mathrm{H}=$ histidina; $\mathrm{N}=$ asparagina; $\mathrm{R}=\operatorname{arginina} ; \mathrm{S}$ = serina; $Y=$ tirosina. 